\title{
Simulated Ground-Water How and Soupces of Water in the Killbuck Creek Valley near Wooster, Wayne County, Ohio
}

By K.J. Breen, A. L Kontis, G.L Rowe, and R.J. Haefner

U.S. GEOLOGIGAL SURVEY

Water-Resources Investigations Report 94-4131

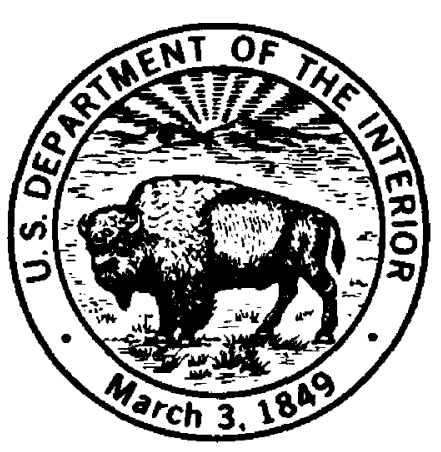

Columbus, Ohio 


\title{
U.S. DEPARTMENT OF THE INTERIOR BRUCE BABBITT, Secretary
}

\author{
U.S. GEOLOGICAL SURVEY \\ GORDON P. EATON, Director
}

For additional information write to:

District Chief

U.S. Geological Survey 975 West Third Avenue Columbus, $\mathrm{OH}$ 43212-3192
Copies of this report may

be purchased from:

U.S. Geological Survey

Earth Science Information Center

Open-File Reports Section

Box 25286, MS 517

Denver Federal Center

Denver, CO 80225 


\section{CONTENTS}

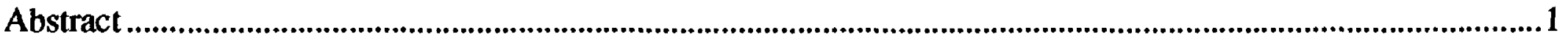

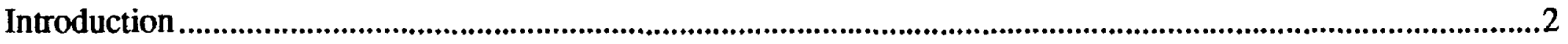

Purpose and scope

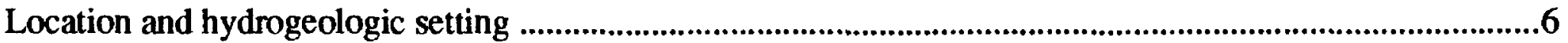

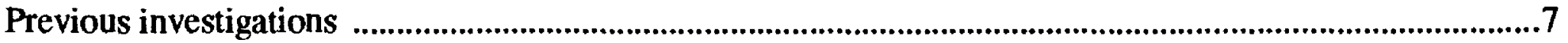

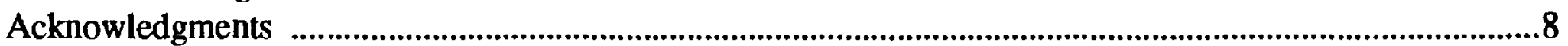

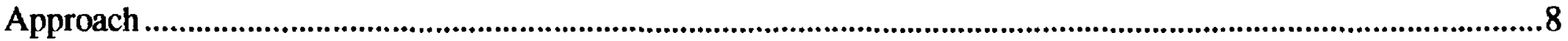

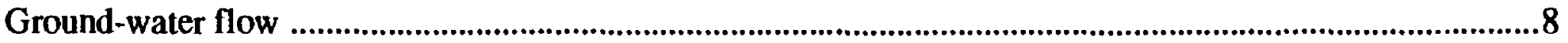

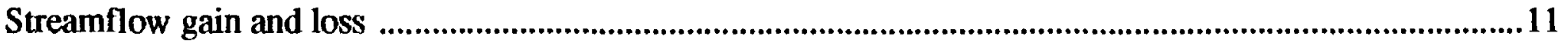

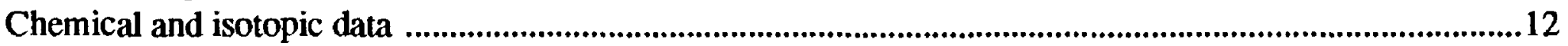

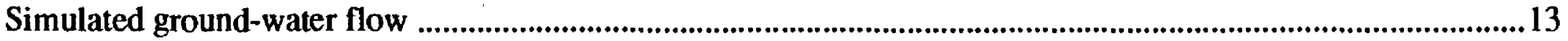

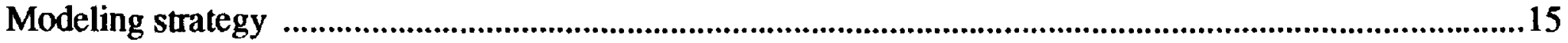

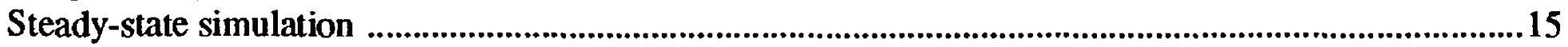

Transient simulation ...............................................................................................................19

Simulation of recharge by Variable-Recharge procedure .........................................................................19

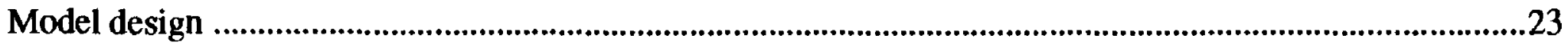

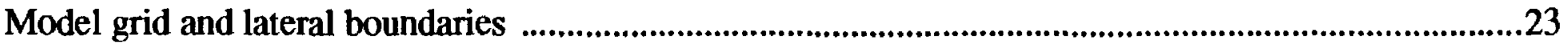

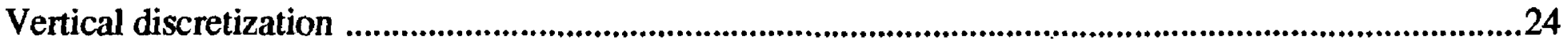

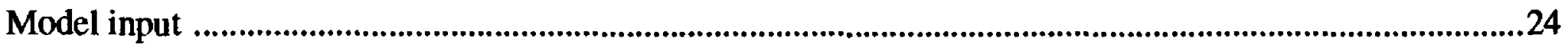

Boundary fluxes and pumping rates .......................................................................................24

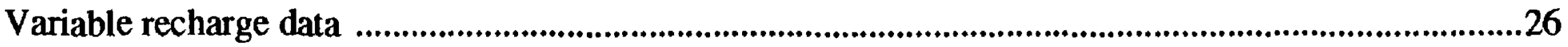

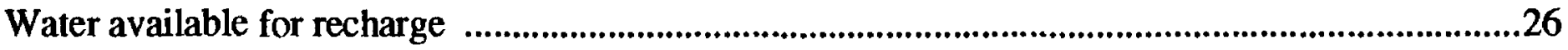

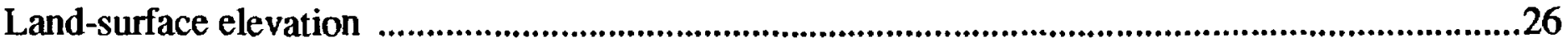

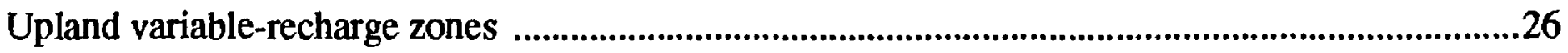

Reduction of water available for recharge and runoff in urban areas ...........................................26

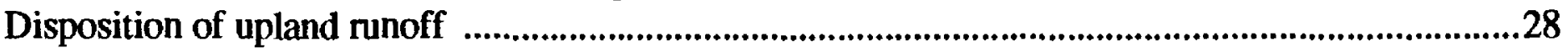

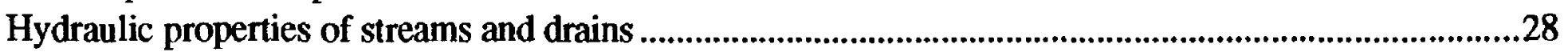

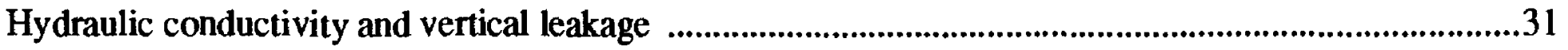

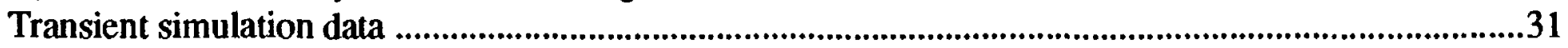

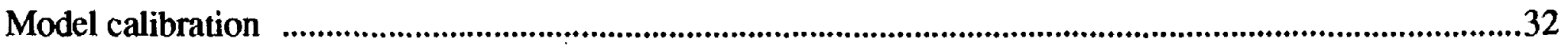

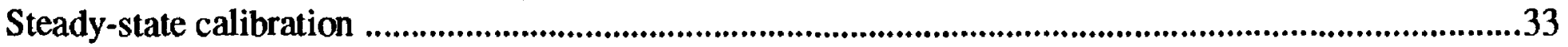

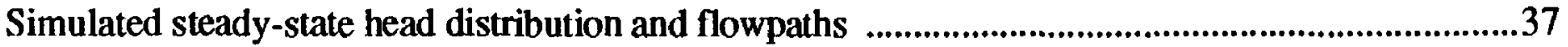

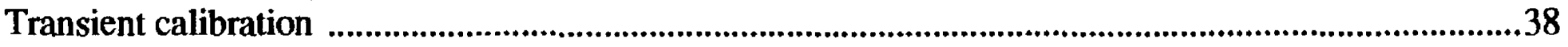

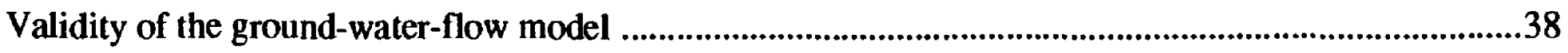

Sources of water in the Killbuck Creek valley .......................................................................................40

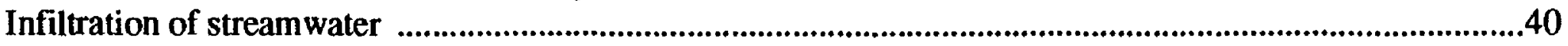

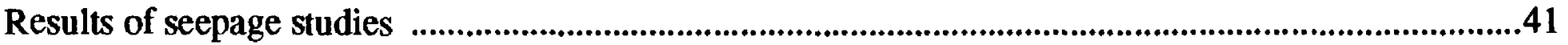

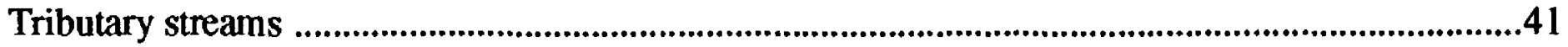

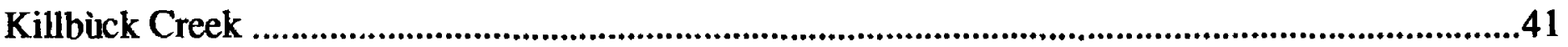

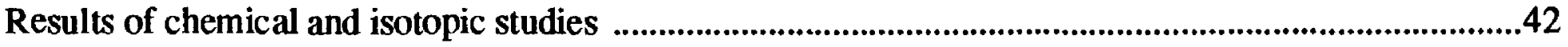

Water in and beneath Killbuck Creek ......................................................................................442

Freshet of February 1985 and streamwater in the stratified drift .................................................4.46

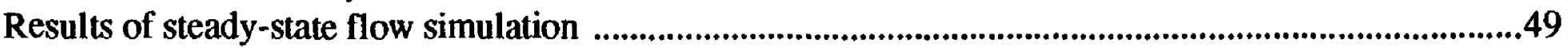

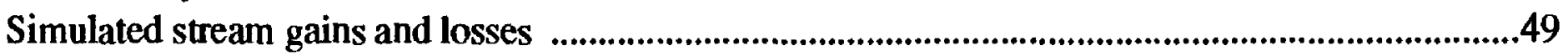

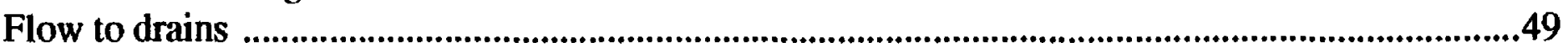

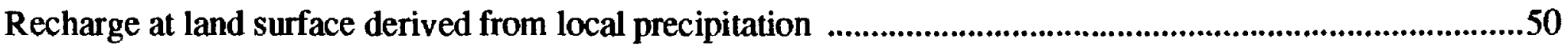

Recharge from precipitation on the valley floor ........................................................................50

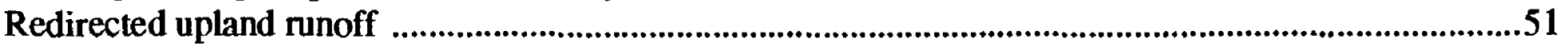

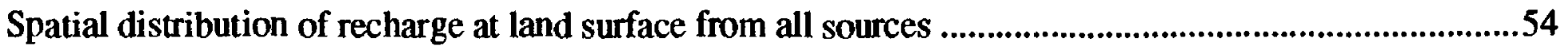




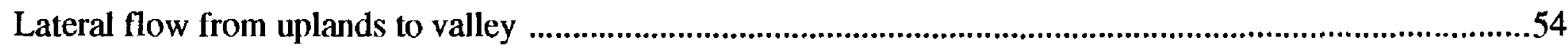

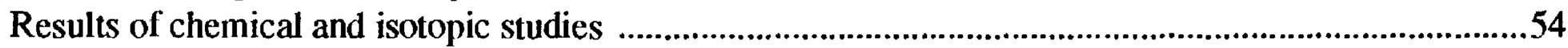

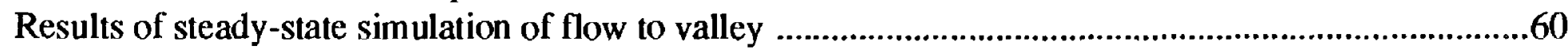

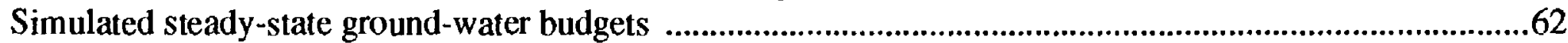

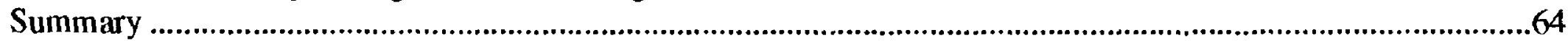

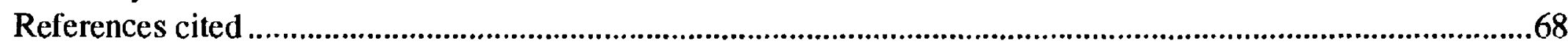

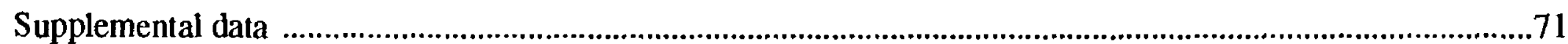

\section{PLATES}

[Plates are in pocket]

Plate 1-8. Map showing:

1. Network of data-collection sites and line-of-section A-A'

2. Model grid, variable-recharge zones, and location of various features simulated by steady-state ground-water-flow model

3. Contours of land-surface elevation array used in Variable-Recharge procedure and location of simulated recharge and seepage areas-steady-state model

4. Ground-water-flow model calibration zones used to generate hydraulic conductivity of layer 1 , and vertical leakance between layers 1 and 2

5. Ground-water-flow model calibration zones used to generate hydraulic conductivity of layers 2 and 3, and vertical leakance between layers 2 and 3

6. Contours of simulated steady-state head (north-well-field subregion) for (A) model layer 1, (B) model layer 2, and (C) model layer 3, and difference between measured and simulated heads representative of fall 1984 conditions

7. Contours of simulated steady-state head for model layer 3 in the entire study area

8. Flow from model layer 1 to layer 2 and range of relative magnitude of vertical recharge to layer 2 for nodes of the steady-state ground-water-flow model

\section{FIGURES}

1. Sources of recharge to stratified drift in valleys in the glaciated northeast.

2. Section A-A' across Killbuck Creek valley showing (A) generalized geology and (B) generalized ground-water-flow-model layering for units shown in figure $2(\mathrm{~A})$.....................4

3. Hydrographs of north well field observation wells D1 through S13 from July 1984 to December 1986

4. Water levels in deep well D2A completed in the stratified drift of Killbuck Creek valley, near Wooster, Ohio, and daily precipitation at Ohio Agricultural Research and Development Center at Wooster, October 1984 through September 1985

5. Contours of simulated steady-state head in south well field subregion for

(A) model layer 2, and (B) model layer 3; and comparison with heads measured on November 25, 1986

6. Mixing relations between surface and ground water beneath Killbuck Creek; based on a mixing line using two estimates of representative isotope composition for ground water and measured composition of Killbuck Creek streamwater collected on (A) July 17 and (B) August 27, 1985

7. Temporal variation of specific conductance of Killbuck Creek (site 1) streamwater and ground water in selected wells, Killbuck Creek valley, near Wooster, Ohio

8. Variable-Recharge procedure allocation of water available for recharge applied to uplands for the steady-state model 
9. Variable-Recharge procedure allocation of upland runoff available to recharge valley for the steady-state model

10. Variation in specific conductance measured at production wells and assignment of western, central, and eastem designations to production waters.....................................56

11. Mixing plot based on sodium and chloride milliequivalents in ground water and the concept of a percentage of shale-sandstone-aquifer water in stratifieddrift-aquifer wells.

12. Mixing relation between shale-sandstone-bedrock water and stratified-drift water near Wooster, Ohio, February 21 to 26, 1985, and comparison to water in Clear Creek and Killbuck Creek based on mixing line using chloride concentrations and $\delta^{18} \mathrm{O}$ values

13. Simulated water budget for the steady-state model

\section{TABLES}

1. Records of wells and a spring in the data-collection network, Killbuck Creek valley, near Wooster, Ohio

2. Records of streambed piezometers in Killbuck Creek and Clear Creek, near Wooster, Ohio

3. Gain/loss discharge measurements on selected reaches of Killbuck Creek, Ohio

4. Gain/loss discharge measurements on selected tributary streams, Killbuck Creek valley, Ohio

5. Ground-water/surface-water level relations at streambed piezometers in Killbuck Creek and Clear Creek near Wooster, Ohio, for the period June through September, 1985

6. Records of ground-water levels in the vicinity of Killbuck Creek valley, near Wooster, Ohio

7. Recharge-induced changes in ground-water conditions at selected wells near the north well field, February 1985 , Wooster, Ohio

8. Boundary fluxes and pumping rates for the steady-state simulation .25

9. Calculation of the water available for recharge, 1984 steady-state simulation and 1985 transient simulation

10. Variable-Recharge procedure input data specifying the distribution of recharge and runoff for upland recharge zones 1 through 15

11. Input data for the Stream and River Packages of the USGS modular ground-waterflow model and Variable-Recharge procedure, steady-state simulation

12. Estimates of horizontal hydraulic properties of sand and gravel deposits from aquifer test data collected in Killbuck Creek valley, Ohio

13. Storage properties and stresses used in the transient simulation

14. Zonal values of horizontal hydraulic conductivity for layer 1 and vertical leakance between layers 1 and 2

15. Zonal values of horizontal hydraulic conductivity for layers 2 and 3 and vertical leakance between layers 2 and 3

16. Comparison of water levels in wells in uplands measured in the fall of 1984 with heads in the uplands from steady-state simulation

17. Simulated heads and head changes for two transient models of period 23 February to 5 March, 1985, and comparison with measured values, northwell-field subregion

18. Selected chemical and isotopic characteristics of streamwaters and of shallow ground water from streambed piezometers in Killbuck Creek 
19. Water-quality records for ground-water and surface-water samples, Killbuck Creek valley near Wooster, Ohio

20. Simulated gains and losses for fall 1984 steady-state model compared to estimates from stream-discharge measurements of September 9, 1985, and August 14, 1986

21. Distribution of valley-vertical recharge from layer $I$ to layer 2 for areas north and south of ground-water divide

22. Net recharge to upland zones and lateral flow from uplands to Killbuck Creek valley, steady-state simulation

23. Water budget for stratified drift, steady-state simulation .62

\section{CONVERSION FACTORS AND VERTICAL DATUM}

\begin{tabular}{rll}
\hline Multiply & by & To obtain \\
inch (in.) & & \\
foot $(\mathrm{ft})$ & 2.54 & millimeter \\
square foot $\left(\mathrm{ft}^{2}\right)$ & 0.3048 & meter \\
mile $\left(\mathrm{mi}^{2}\right)$ & .0929 & square meter \\
square mile $\left(\mathrm{mi}^{2}\right)$ & 1.609 & kilometer \\
acre & 2.589 & square kilometer \\
inches per hour & $4,047.0$ & square meter \\
inches per year & 2.54 & centimeters per hour \\
foot per day $(\mathrm{ft} / \mathrm{d})$ & 2.54 & centimeters per year \\
foot per mile $\left(\mathrm{ft}^{2} / \mathrm{mi}^{2}\right)$ & 0.3048 & meter per day \\
foot squared per day $\left(\mathrm{ft}^{2} / \mathrm{d}\right)$ & 0.1894 & meter per kilometer \\
cubic foot per second $\left(\mathrm{ft}^{3} / \mathrm{s}\right)$ & 0.0929 & meter squared per day \\
cubic foot per day $\left(\mathrm{ft}^{3} / \mathrm{d}\right)$ & 0.02832 & cubic meter per second \\
gallons per minute $\left(\mathrm{gal}^{3} / \mathrm{min}\right)$ & 0.02832 & cubic meter per day \\
gallons per day $(\mathrm{gal} / \mathrm{d})$ & 0.06308 & liters per second \\
million gallons per day $(\mathrm{Mgal} / \mathrm{d})$ & 3.785 & liters per day \\
\end{tabular}

Concentrations of chemical constituents and temperatures of air and water are given in metric units. Concentration is given in milligrams per liter $(\mathrm{mg} / \mathrm{L})$; this unit expresses the concentration of chemical constituents in solution as weight (milligrams) of solute per unit volume (liter) of solution (water). For concentrations of dissolved solids in water less than $7,000 \mathrm{mg} / \mathrm{L}$, the numerical values are, for practical purposes, the same as for concentrations in parts per million.

Water and air temperatures in degrees Celsius $\left({ }^{\circ} \mathrm{C}\right)$ can be converted to degrees Fahrenheit $\left({ }^{\circ} \mathrm{F}\right)$ by the following equation:

$$
{ }^{\circ} \mathrm{F}=1.8\left({ }^{\circ} \mathrm{C}\right)+32
$$

Sea level: In this report, "sea level" refers to the National Geodetic Vertical Datum of 1929 (NGVD of 1929)-a geodetic datum derived from a general adjustment of the first-order level nets of both the United States and Canada, formerly called Sea Level Datum of 1929. 


\title{
Simulated Ground-Water Flow and Sources of Water in the Killbuck Creek Valley Near Wooster, Wayne County, Ohio
}

\author{
By Kevin J. Breen, Angelo L. Kontis, Gary L. Rowe, and Ralph J. Haefner
}

\section{Abstract}

The stratified-drift aquifer in the 3,000-ft (feet)-wide and 100-ft-deep buried valley of Killbuck Creek near Wooster in northeastern Ohio was studied. The stratified drift with adjacent sandstone and shale bedrock produce a system of ground-water flow representative of the western part of the glaciated northeastern United States. The stratified-drift aquifer is an excellent source of water for municipal and industrial wells. The aquifer is recharged locally by water from precipitation on the valley floor and uplands, by infiltration from streams, and by lateral flow to the valley from the uplands. As a result, the aquifer is vulnerable to surface or subsurface spills of contaminants in the valley or the adjacent uplands. Quality of water in the stratified drift is affected by influx of water from bedrock lateral to or beneath the valley. This influx is controlled, in part, by the pumping stress placed on the stratified-drift aquifer.

Hydrogeologic and aqueousgeochemical data were analyzed to establish the framework necessary for steady-state and transient simulations of ground-water flow in stratified drift and bedrock with a three-layer ground-water-flow model. A new model routine, the Variable-Recharge procedure, was developed to simulate areal recharge and the contribution of the uplands to the drift system. This procedure allows for water applied to land surface to infiltrate or to be rejected. Rejected recharge and ground water discharged when the water table is at land surface form surface runoff-this excess upland water can be redirected as runoff to other parts of the model.

Infiltration of streamwater, areal recharge to the uplands and valley, and lateral subsurface flow from the uplands to the valley are sources of water to the stratified-drift aquifer. Water is removed from the stratifieddrift aquifer at Wooster primarily by production wells pumping at a rate of approximately $8.5 \mathrm{ft}^{3} / \mathrm{s}$ (cubic feet per second). The ground-water budget resulting from two types of simulations of ground-water flow in this study indicates the primary sources of water to the wells are recharge at or near land surface and lateral subsurface flow from the shale and sandstone bedrock. Components of recharge at land surface include induced infiltration from streams, precipitation on the valley floor, and infiltration of unchanneled upland runoff that reaches the valley floor.

The steady-state simulation was designed to represent conditions during the fall of 1984. The transient simulation was designed to represent an 11-day snowmelt event, 23 February to 5 March 1985, that caused water levels to rise significantly throughout the valley. Areal recharge to the valley and flow from the uplands to the valley were determined through the VariableRecharge procedure. The total steady-state recharge to the valley was $12.5 \mathrm{ft}^{3} / \mathrm{s}$. Upland sources, areal valley recharge, and induced infiltration from Killbuck Creek accounted for 63,23 , and 8 percent, respectively, of the valley recharge. 
An analysis of the simulated vertical flow to the buried stratified drift through surficial silt, clay, and fine sand indicates that about 75 percent of the total recharge to the buried deposits is the sum of areally extensive, relatively small flows (less than about $0.01 \mathrm{ft}^{3} / \mathrm{s}$ per model node), whereas about 25 percent of the recharge results from areally restricted, relatively large flows (greater than about $0.1 \mathrm{ft}^{3} / \mathrm{s}$ per model node). The large-magnitude flows are located primarily beneath Clear and Little Killbuck Creeks where seepage provides abundant recharge and the surficial sediments grade into coarser alluvial-fan deposits.

Chemical and isotopic studies of ground water and streamwater combined with measurements of stream infiltration provide independent support for the conclusions derived from computer simulations of ground-water flow. In addition, the chemical and isotopic studies helped quantify the rate and pathways of infiltrating water from the surface to the production wells. Isotopic compositions of streamwater and streambed water show that the transport time from the streams to the stratified-drift aquifer ranges from several days to several weeks. The chemical and isotopic data indicate that the streamwater is diluted and mixed with ground water and dispersed within the stratified drift such that it is chemically and isotopically unrecognizable as streamwater at the production wells. The time estimated for infiltrating streamwater to reach the shallow ground-water system beneath the stream is likely 2 months or more.

\section{INTRODUCTION}

The Regional Aquifer-System Analysis (RASA) program of the U.S. Geological Survey (USGS) was designed to provide information for managing the ground-water resources of regional aquifers or aquifers sharing similar characteristics within regions of the United States. The Northeast Glacial Aquifers (NEGA) RASA Program was a study of the hydrology of sand and gravel deposits formed largely by glacial meltwater in the glaciated northeastern United States. The purpose of the NEGA-RASA is to provide information that can be used to assess ground-water supplies and project responses to pumping stress, climatic stress, and contamination incidents.

The stratified drift in Killbuck Creek valley in northeastem Ohio was selected for study because the aquifer system has several features common to valley-fill aquifer systems in the western part of the glaciated northeastem United States. These features include (1) a valley fill composed of sand and gravel interbedded with confining layers of till and glaciallake sediments, (2) an adjoining and underlying sequence of shales and sandstones, and (3) a large pumping stress close to a major stream that provides an opportunity to evaluate factors that control induced recharge.

Natural and induced recharge are sources of water to bedrock valley-fill aquifers. The chief sources of natural recharge to stratified-drift aquifers (Morrissey and others, 1988, p. 20) are (1) precipitation on the valley floor, and (2) recharge from upland sources that include seepage from tributary streams, unchanneled storm runoff and (or) ground-water flow from upland hillsides, and regional ground-water flow through bedrock (fig. 1). Induced recharge (infiltration of water from a stream to a stratified-drift aquifer) can be a source of water if a pumping stress is close to the stream and the streambed is composed of relatively permeable materials.

The initial objective of this study was to define the hydraulic properties that control stream and stratified-drift-aquifer interactions. The study was initially focused on the stream-aquifer interactions but had to be expanded because definition of the hydraulic properties required a knowledge of several other hydrologic factors such as recharge to the stratified-drift aquifer from bedrock shale and sandstone (hereafter termed shale-sandstone aquifer), direct recharge from precipitation, and leakage through confining beds.

\section{Purpose and Scope}

The purpose of this report is to evaluate quantitatively the sources of water in a stratifieddrift aquifer that is stressed by pumping. Three categories of water sources are evaluatedinfiltration of streamwater, areal recharge in the uplands and valley, and lateral flow from the uplands to the valley. 


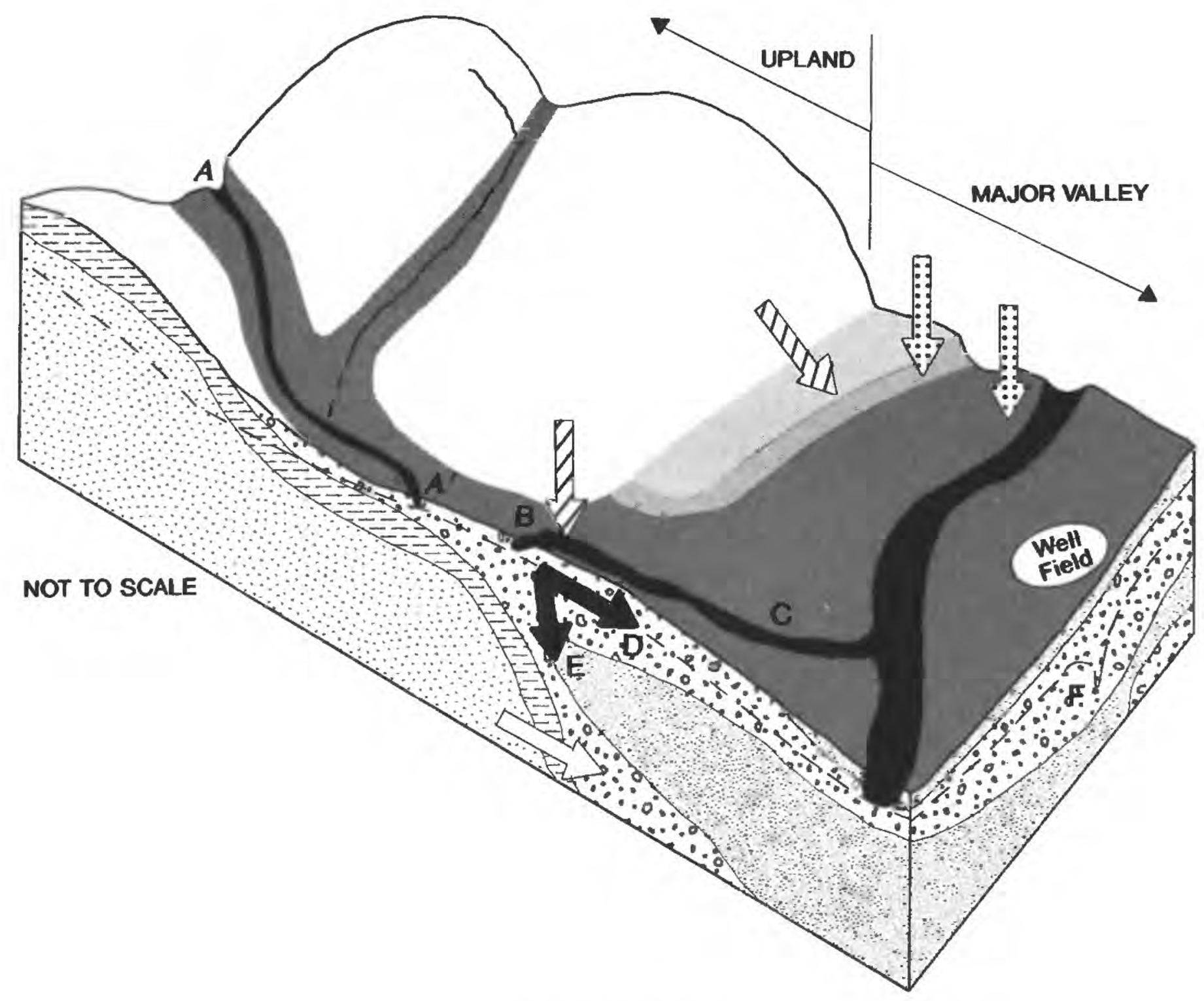

EXPLANATION

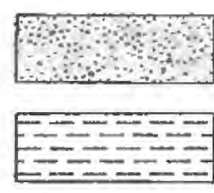

SAND AND GRAVEL

TILL

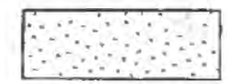

BEDROCK

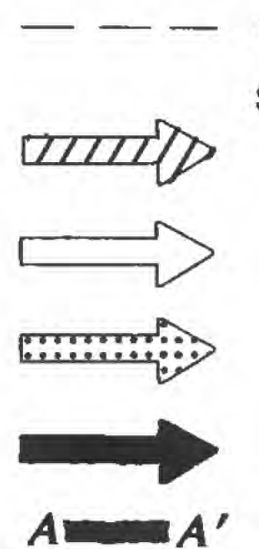

WATER TABLE

SOURCES OF RECHARGE TO SAND AND GRAVEL IN MAJOR VALLEYS

Unchanneled storm runoff and (or) ground-water flow from upland hillsides

Regional ground-water flow through bedrock

Precipitation on the valley floor

Tributary-stream infiltration--see letters A-F

B Edge of major valley where wider, thicker sand and gravel deposits transmit more water than alluvium in tributary valley, so that water table drops below tributary channel and tributary loses water to the underlaying aquifer

C Tributary goes dry--where cumulative seepage loss equals streamflow at $A^{\prime}$

D Recharge that moves laterally to river

E Recharge that moves downward to deeper aquifers

F Cone of depression due to pumping at well field

Figure 1. Sources of recharge to stratified drift in valleys in the glaciated northeast. (Modified from Morrissey and other, 1989, fig. 1.) 


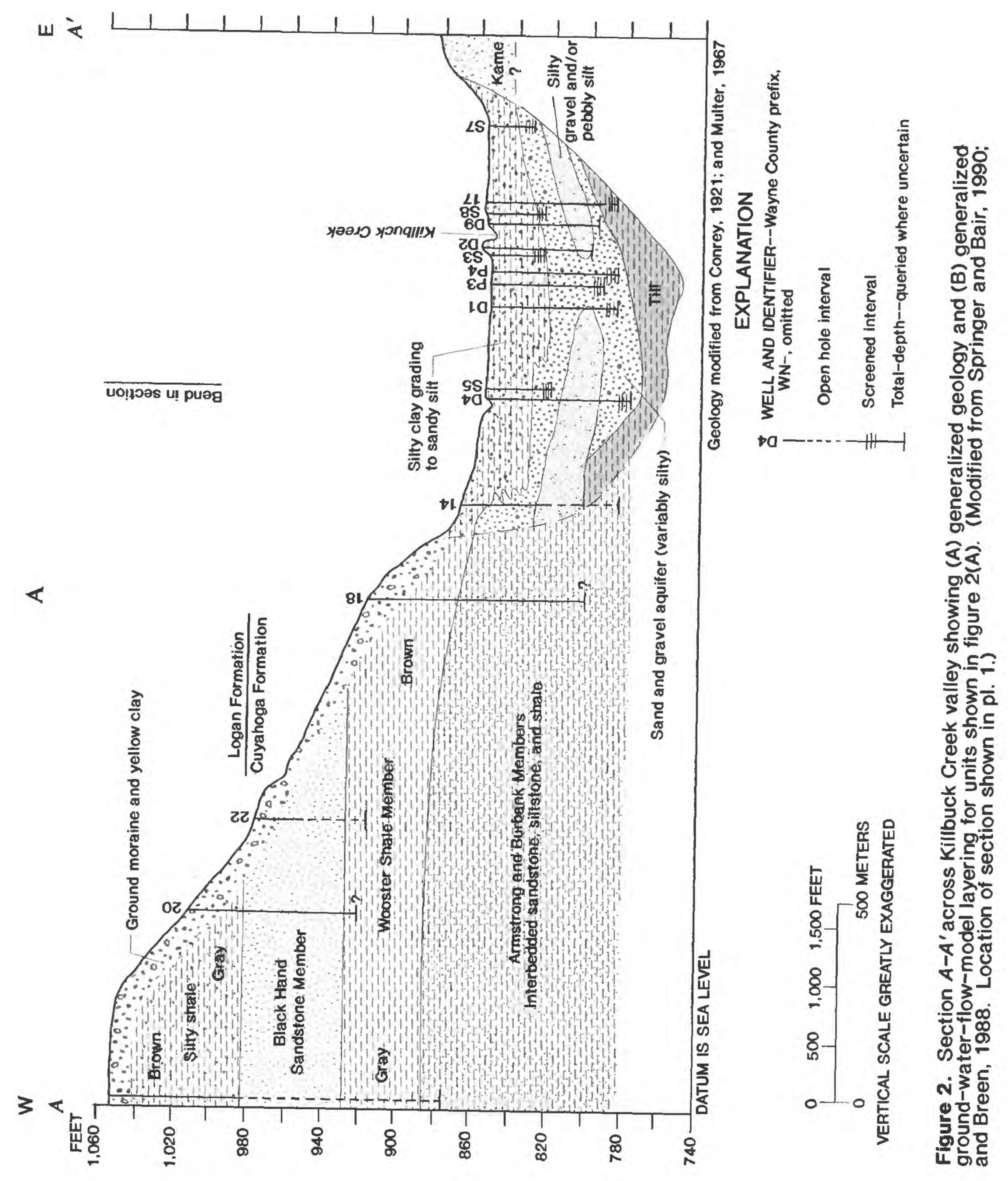




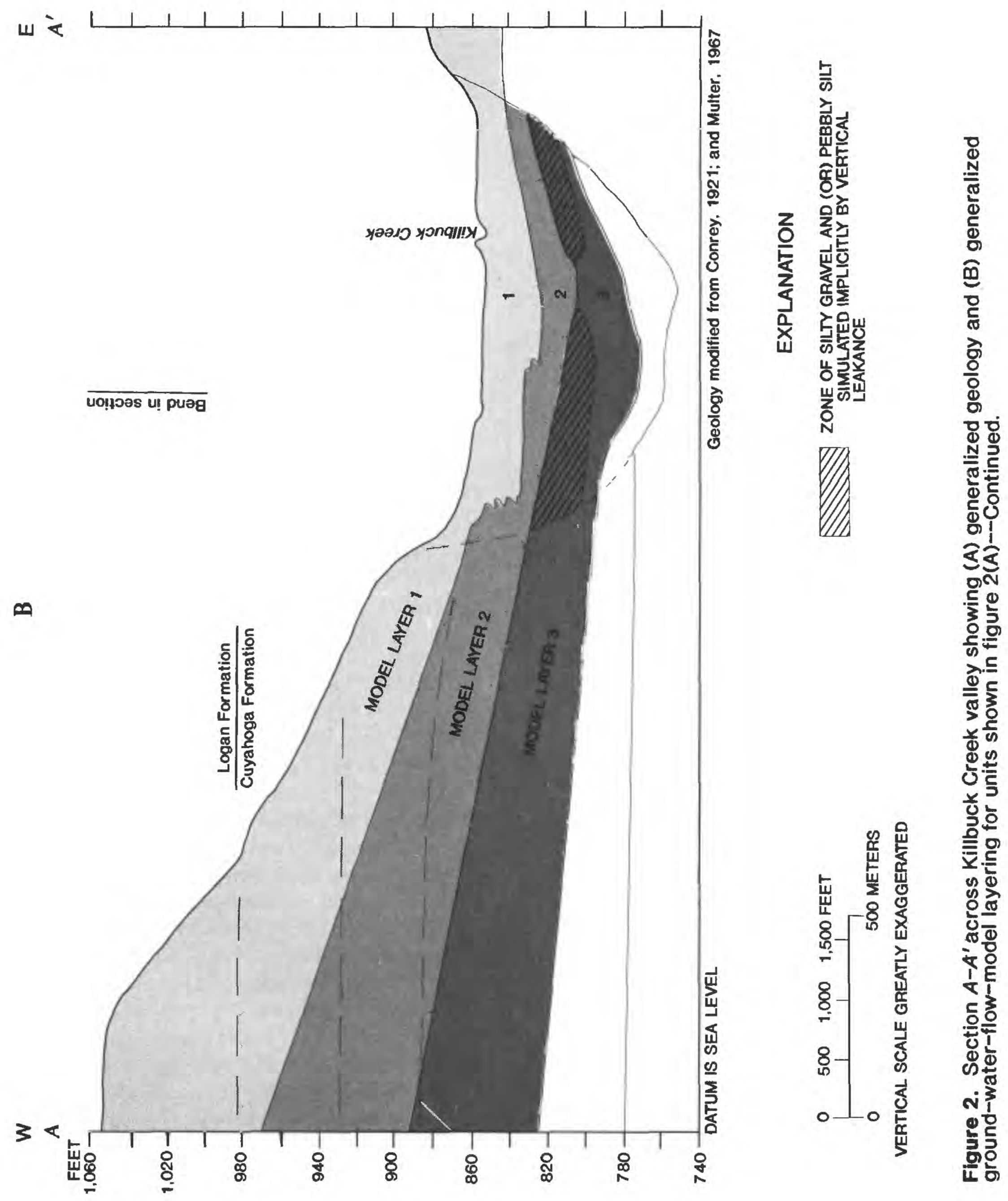


The evaluation was made by (1) review of available hydrogeologic data, (2) measurement of hydraulic head and water chemistry in the stratifieddrift aquifer and the adjoining and underlying shalesandstone aquifer, (3) measurement of stream gain or loss and streamwater chemistry, (4) estimation of ground-water recharge and discharge by use of a 3-dimensional numerical simulation, and (5) comparison of water-source estimates from the simulations of ground-water flow and geochemical techniques.

This report summarizes water-level data from 41 wells, including piezometers driven into the streambeds. The chemistry of water from 21 wells and 6 stream sites also is summarized. Procedures used for the simulation of ground-water flow are described in detail because they incorporate a new method for simulation of recharge. This report contains tabulations of the water-level and waterquality data collected by the USGS during this investigation.

\section{Location and Hydrogeologic Setting}

The study area (pl. 1) is in central Wayne County, Ohio. Wayne County is in the glaciated Appalachian Plateaus physiographic province (Meinzer, 1923; Fenneman, 1938). The Killbuck Creek valley, west of the City of Wooster (population 22,800 in 1990), is representative of the highly productive stratified-drift aquifers often used for public-water supply in northeastem Ohio. Two well fields, hereafter called the north and south well fields, tap the stratified drift and supply water for Wooster.

The stratified drift in Killbuck Creek valley is an excellent aquifer suitable for municipal and industrial well field development (Crowell, 1979). Sustained yields from wells of greater than $100 \mathrm{gal} / \mathrm{min}$ characterize the aquifer near Wooster. Water for Wooster is withdrawn from the stratifieddrift aquifer at rates that range from 3 to 4.5 Mgal/d (City of Wooster, written commun., 1985). The stratigraphy of drift deposits and geometry of the bedrock valley are shown in a generalized geologic section through the valley (fig. 2A).

The valley fill averages about $3,000 \mathrm{ft}$ in width at the north well field and is up to 100 to $120 \mathrm{ft}$ thick in the middle of the valley. The uppermost part of the valley-fill deposits can be characterized as follows: It is less than 20 to $30 \mathrm{ft}$ thick, consists primarily of silt and clay with some fine sand. contains alluvial-fan deposits at the valley margins, is partly saturated, underlies the streambed of Killbuck Creek, and is heterogeneous with respect to hydraulic properties. These deposits are unconfined and are a semiconfining unit for the gravel aquifers in most of the valley. Beneath the uppermost deposits, the drift deposits range in composition from silty clay to gravel. Interbeds of silty gravel and (or) pebbly silt with silt and clay create a system in which the gravel aquifer is locally hydraulically separated into confined and semiconfined gravel zones. Near the pumped wells at the north well field, the upper part of the gravel aquifer is unsaturated.

Shales and sandstones of the Cuyahoga and Logan Formations (Conrey, 1921; Multer, 1967) underlie the Killbuck Creek valley and the adjacent uplands (fig. 2). The bedrock uplands are important shale-sandstone aquifers for rural domestic and commercial water supplies. The Cuyahoga Formation is the primary source of water for wells adjacent to the Killbuck Creek valley. Wells completed in the Black Hand Sandstone Member yield water that has a lower specific conductivity than water from wells completed beneath the Wooster Shale Member. Thus, the upper part of the bedrock contains water that differs chemically from the water in the Armstrong Sandstone and Burbank Members. This indicates a ground-water-flow system in the bedrock that has shallow and deep components. Available data for Wayne County, Ohio, from Sedam and Stein (1970) show that ground waters in the Cuyahoga Formation have concentrations of dissolved solids (or values of specific conductance) that generally increase with depth.

The flow of ground water in the bedrock is primarily along fractures, joints, and bedding planes. Hydraulic heads in bedrock wells adjacent to the valley indicate a pattern of subhorizontal ground-water flow toward the axis of the valley. A potential downward vertlcal flow across the Wooster Shale Member exists in the uplands adjacent to the valley, but data are lacking to determine vertical flow directions in bedrock 
beneath the valley fill.

Killbuck Creek flows into the study area from the northwest (pl. 1). The creek channel is adjacent to the steep bedrock slopes at the eastern edge of the valley as far south as Silver Road. At Silver Road, the stream is channeled toward the middle of the valley. To stop frequent spring flooding, the reach of Killbuck Creek between Silver Road and U.S. Route 30 has been straightened and bordered by levees constructed from nalural earthen materials.

Tributary streams to Killbuck Creek originate in the uplands. During base flow, flow in these streams consists of ground water from springs and seeps that discharges from the bedrock. The named tributaries draining the uplands on the east side of the valley are Clear Creek, Apple Creek, and Christmas Run. On the west side of the valley, Rathburn Run drains a part of the uplands and flows into Little Killbuck Creek, the major tributary flowing into Killbuck Creek. Numerous small unnamed streams flow from the uplands and channel base flow and upland runoff directly onto the valley floor. Tributary streams lose water as they flow across permeable alluvial-fan deposits on the margins of the valley floor. These stream losses represent sources of recharge to the stratified-drift aquifer.

\section{Previous Investigations}

Information on the hydrogeology of the Killbuck Creek valley is primarily from engineering reports describing the development of the stratified-drift aquifer as a water supply for Wooster. The aquifer characteristics were first mapped on the basis of data from geophysical surveys and drilled test wells (Jones and others, 1958). Characteristics of the stratified-drift aquifer south of Wooster were described in more detail during the engineering of the south well field (Miller, 1976, pl. 1; and Miller and Associates, 1982).

In 1983, organic contaminants were detected in water from the south well field. Since 1983, investigations of the occurrence and possible source of contaminants at the south well field have included completion of about 30 test wells.
As a result, extensive geologic and hydrogeologic data are available for the south well field area (Mayhew, 1985).

In June 1984, the USGS began an investigation of the ground-water hydrology and aqueous geochemistry in the Killbuck Creek valley. During 1984-86, ground-water data collected by the USGS were published annually (Shindel and others, 1985, 1986, and 1987). The annual reports included ground-water-level data and data from stream gain/loss measurements. The geochemical and isotopic studies of the north well field area (Breen, 1988; and Dysart, 1988) describe the chenical evidence for waters in the stratified-drift aquifer originating, in part, from sandstones and shales that adjoin and underlie the drift and also show the variability in water chemistry that characterizes the north well field area.

In 1986, monthly measurements of groundwater levels in observation wells were continued at the north well field and were started at the south well field by students at the College of Wooster (Springer, 1987) and The Ohio State University (E.S. Bair, The Ohio State University, written commun., 1986).

In December 1988, the USGS measured vertical hydraulic conductivity of the streambed with a seepage meter at selected locations. This work was an attempt to improve the inconclusive results on gain/loss properties from the 1985-86 study.

Research at The Ohio State University on the hydrogeology of the stratified-drift aquifer continued through 1990. Springer and Bair (1990) applied a semianalytical technique to generate ground-water-flow models of the north and south well fields. In particular, they used a combination of the Theis equation and image-well theory to compute drawdown from predevelopment potentiometric surfaces at uniformly spaced points (400 $\mathrm{ft}$ for the north well field and $250 \mathrm{ft}$ for the south well field). In an ongoing effort, Springer (1990) developed analytical and numerical models of both well fields to compare various methods of delineating well-field protection areas. Springer and Bair (1992) added a semianalytical model in their analysis. 


\section{Acknowledgments}

The assistance and access to wells provided by the City of Wooster is gratefully acknowledged. Appreciation is expressed also to private landowners who granted access to wells and spring WN-32, and who allowed numerous traverses with geophysical instruments.

\section{APPROACH}

Three types of field investigations were done to evaluate the sources of water in the stratified-drift aquifer. These included investigations of groundwater-flow characteristics, stream gain/loss and seepage characteristics, and chemical and isotopic characteristics of surface and ground water.

A network of data-collection sites was established to facilitate these investigations (pl. 1). The network included 26 wells and 1 spring in the drift aquifer and 9 wells in the shale-sandstone aquifer (table 1). Fourlcen observation wells were installed for this study, all in the north well field area (pl. 1). All observation wells listed in table 1 (except WN-D2A, WN-S6A, and WN-3, which were installed by the City of Wooster, Wooster Township, and the State of Ohio, respectively) were installed with an auger drill rig, cased with 2-in. i.d. (inside diameter) PVC casing, and finished with a well screen having a 0.010-in. slot size. Well S6A is a piezometer similar to those installed in the streams (the Wayne County prefix, WN-, is hereafter omitted from well numbers). The depth of well completion is reflected in the shallow (S) and deep (D) designations in the local well numbers. Three wells in the drift aquifer and one well in the shale-sandstone aquifer were equipped with hourly water-level recorders. The data-collection network also included 10 piezometers driven into the drift aquifer beneath the streambed in Killbuck Creek, and 1 piezometer driven into Clear Creek (table 2). Streambed piczometers were installed by use of a hand-held or motorized driver. Piezometers consist of 1.25-in. i.d. galvanized steel pipe attached by a threaded coupling to a well point $0.5 \mathrm{ft}$ long with 40-mesh (0.016-in.) wire-screen openings. The network also included six discharge-measurement sections on Killbuck Creek (table 3), five sections on Little Killbuck Creek, and two sections on Clear
Creek (table 4).

Geologic and hydrogeologic information obtained from the data-collection network is on file at the USGS Water Resources Division office in Columbus, Ohio, and only the most relevant data are tabulated in this report. Also on file are geologic and hydrogeologic information obtained from logs and engineering reports from earlier test-drilling programs for well-field development and from logs of subsurface borings on file at the Ohio Department of Transportation, Columbus, Ohio. Precipitation data and climatological records from a weather station 1 mile east of the Killbuck Creek valley at the Onio Agricultural Research and Development Center are published by the U.S. National Oceanic and Atmospheric Administration.

\section{Ground-Water Flow}

For investigations of ground-water flow, water levels in wells and streambed piezometers were measured by chalked-steel tape or water-stage recorder in feet below land surface. The accuracy of the water-level measurements is to $0.01 \mathrm{ft}$. Waterlevel altitudes were computed by subtracting the water level, in feet below land surface, from the land-surface elevation at the well site. The landsurface elevations and the altitude of the mcasuring point at each well site was determined either by leveling from a USGS benchmark at the north well field or from USGS 7.5-minute topographicquadrangle maps with 20 -ft contour intervals.

Stream stage was converted to a stream-surface elevation for use in contouring the potentiometric surface in the drift aquifer. Stream stage in Killbuck Creek at Old Mansfield Road was measured with a 15-minute stage recorder. Measurements of stream stages at other locations were made relative to reference points on bridges and streambed piezometers. Elevations of reference points were determined by leveling from a USGS benclimark at the north well field.

Water-level data and information on the hydrologic framework of the aquifer system were used to construct a three-dimensional groundwater-flow model of the Killbuck Creek valley. The USGS modular model (McDonald and Harbaugh, 1988) was used to simulate flow conditions in an attempt to quantify the sources of water to the 


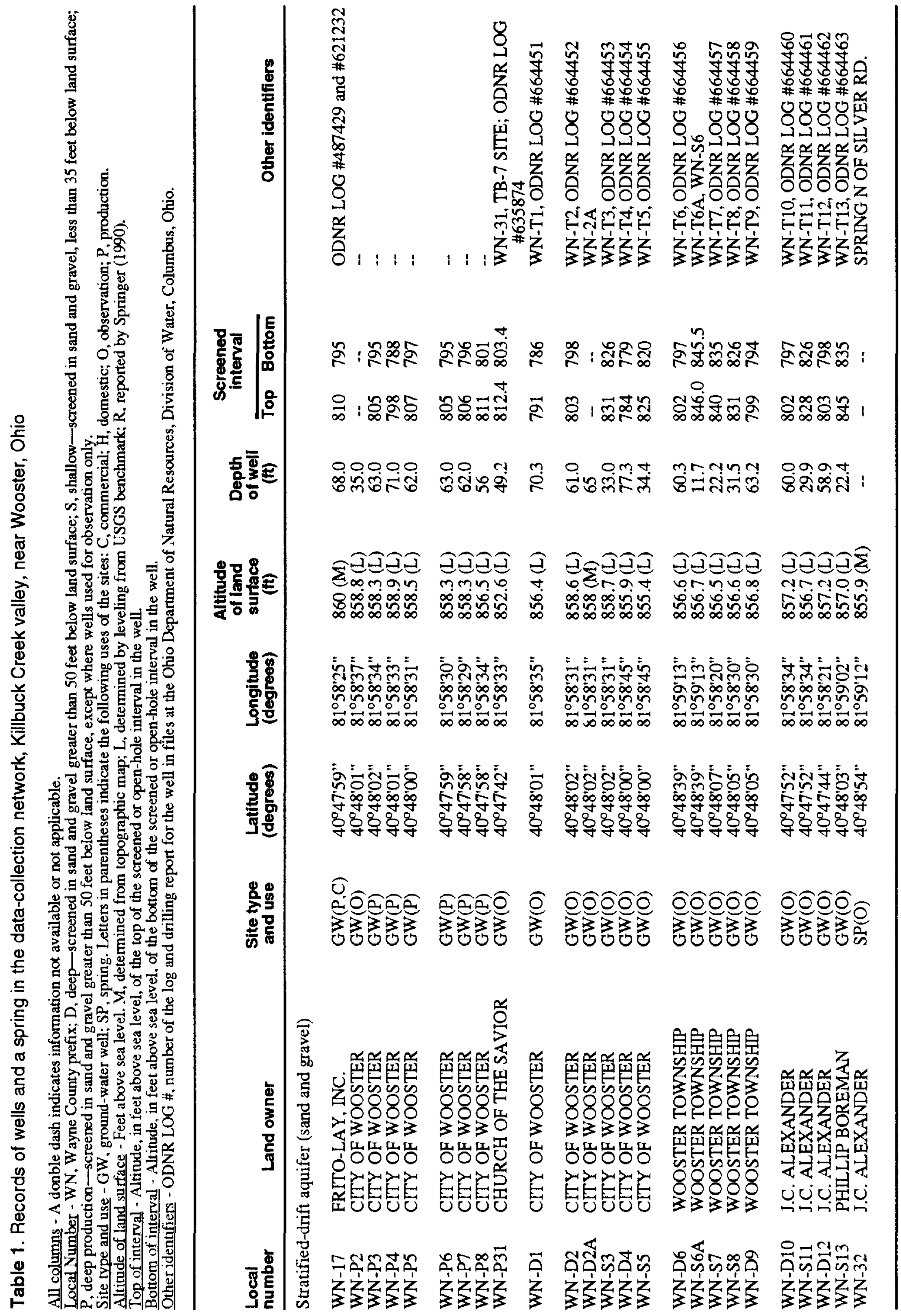




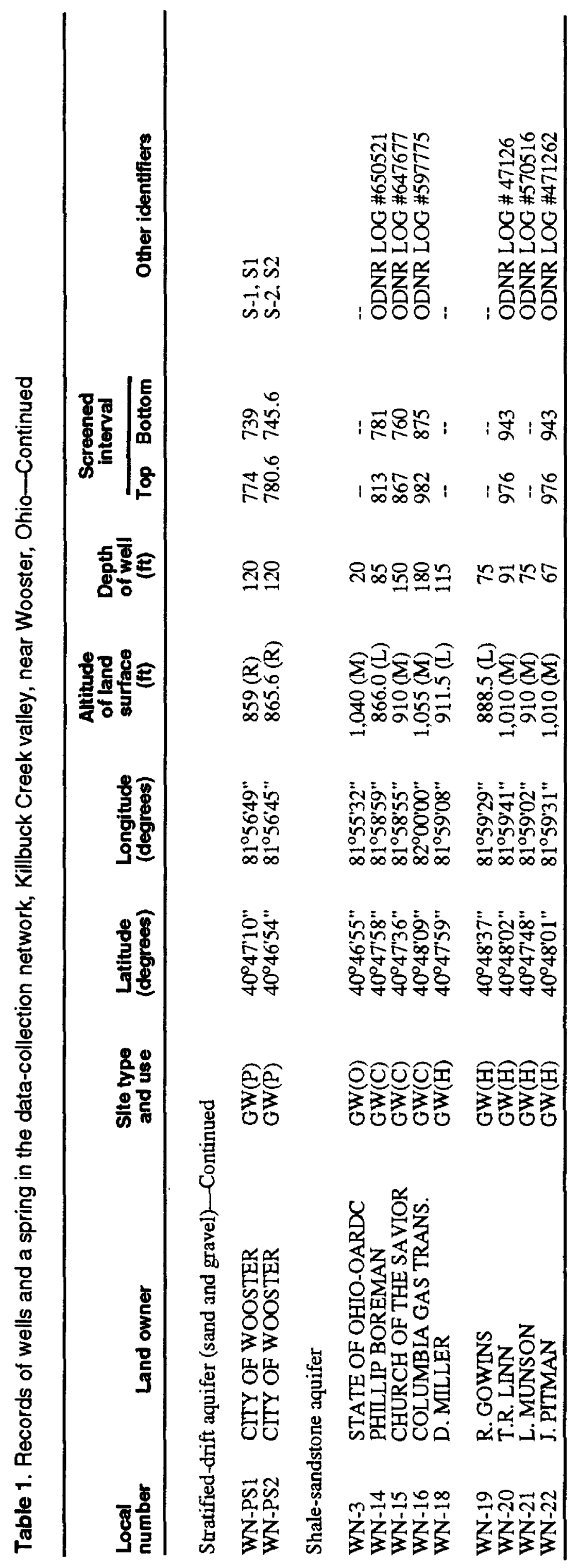


Table 2. Records of streambed piezometers in Killbuck Creek and Clear Creek, near Wooster, Ohio

IWayne County prefix, WN-, onitted from local number, latitude and longitude are in degrees, minutes, and seconds; all other entries are elevations, in feet above sea level, except for depth of well]

\begin{tabular}{lllllll}
\hline $\begin{array}{l}\text { Local } \\
\text { number Latitude }\end{array}$ Longitude & MP1 & LSD' & $\begin{array}{c}\text { Depth } \\
\text { of } \\
\text { well }\end{array}$ & $\begin{array}{c}\text { Bottom } \\
\text { of } \\
\text { well }\end{array}$ & $\begin{array}{c}\text { Top } \\
\text { of } \\
\text { screen }\end{array}$ & $\begin{array}{c}\text { Bottom } \\
\text { of } \\
\text { screen }\end{array}$ \\
\hline
\end{tabular}

\begin{tabular}{|c|c|c|c|c|c|c|c|}
\hline \multicolumn{8}{|c|}{ Killbuck Creek } \\
\hline $40^{\circ} 48^{\prime}\left(96^{\prime \prime}\right.$ & $81^{\circ} 588^{\prime \prime}$ & 850.5 & 847.8 & 11.40 & 836.37 & 837.27 & 836.77 \\
\hline $40^{\circ} 48^{\prime} 39^{\prime \prime}$ & $81^{\prime \prime 58 ' 52 " ~}$ & 854.6 & 851.4 & 6.14 & 845.21 & 846.11 & 845.61 \\
\hline $40^{\circ} 48^{\prime} 25^{\prime \prime}$ & $81^{\circ} 58^{\prime} 49^{\prime \prime}$ & 851.4 & 848.4 & 6.32 & 842.03 & 842.93 & 842.43 \\
\hline $40^{\circ} 48.25^{\prime \prime}$ & $81^{\circ} 58.49^{\prime \prime}$ & 852.0 & 848.3 & 10.54 & 837.79 & 838.69 & 838.19 \\
\hline $40^{\circ} 48^{\prime} 18^{\prime \prime}$ & $81^{\circ} 58^{\prime} 44^{\prime \prime}$ & 850.2 & 846.4 & 8.93 & 837.50 & 838.40 & 837.90 \\
\hline $40^{\circ} 48^{\prime} 18^{\prime \prime}$ & $81^{\circ} 58^{\prime} 44^{\prime \prime}$ & 850.5 & 846.4 & 6.28 & 840.08 & 840.98 & 840.48 \\
\hline $40^{\circ} 48^{\prime} 13^{\prime \prime}$ & $81^{\circ} 58^{\prime} 41^{\prime \prime}$ & 849.8 & 846.8 & 7.45 & 839.33 & 840.23 & 839.73 \\
\hline $40^{\circ} 47^{\circ} 59^{\prime \prime}$ & $81^{\circ} 58^{\prime} 28^{\prime \prime}$ & 847.9 & 846.0 & 8.60 & 837.46 & 838.36 & 837.86 \\
\hline $40^{\circ} 48^{\circ} 39^{\prime \prime}$ & $81^{\circ} 58^{\prime} 52^{\prime \prime}$ & 854.8 & 851.2 & 13.00 & 838.19 & 839.09 & 838.59 \\
\hline $40^{\circ} 47^{\circ} 35^{\prime \prime}$ & $81^{\circ} 58^{\prime}\left(03^{\prime \prime}\right.$ & 849. & 846. & 14.9 & 831.1 & 834.5 & 831.5 \\
\hline \multicolumn{8}{|c|}{ Clear Creek } \\
\hline $40^{\circ} 48^{\prime} 10^{\prime \prime}$ & $81^{\circ} 58^{\prime} 34^{\prime \prime}$ & 850.8 & 850.0 & 8.61 & 842.17 & 843.07 & 842.57 \\
\hline
\end{tabular}

stratified-drift aquifer. Conditions during the fall of 1984 were used to calibrate a steady-state simulation. The calibrated steady-state model was used as the basis for a transient simulation of conditions during a period of intense recharge to the aquifer from a snowmelt event in February 1985. The characteristics of the model are described in detail in the section on "Simulation of Ground-Water Flow."

\section{Streamflow Gain and Loss}

Stream gain/loss studies were made in September 1985 and August 1986 along selected reaches of Killbuck Creek, Little Killbuck Creek, and Clear Creek, with two additional stations on a small tributary (Cashey Creek) and a field-tile drain to Killbuck Creek (tables 3 and 4). Discharge measurements were made in duplicate at each station. Hydraulic heads at streambed piezometers were measured to determine gradients between the stream and shallow ground water beneath Killbuck Creek and Clear Creek during the gain/loss studies (table 5).

A seepage meter (Lee and Cherry, 1978, p. 8) was used in December 1988 at one location on Clear Creek and at three locations along Killbuck Creek. The device is the top 18 in. of a 55-gal metal drum with a nonremovable lid that has handles and a reinforced area to drive it into the stream bed. An opening on top of the drum is fitted with a rubber stopper and tubing that connects to a plastic bag. A streambed piezometer with a $0.5-\mathrm{ft}$ screen is driven into the streambed next to the drum so that the midpoint of the screen is $18 \mathrm{in}$. below the streambed. The hydraulic head difference between the stream and piezometer is measured. $A$ known volume of water is put into the plastic bag, all air is evacuated, and the bag is connected to the opening in the drum by the tubing and stopper. After a measured time interval, the tube between the bag 
Table 3. Gain/loss discharge measurements on selected reaches of Killbuck Creek, Ohio

[Wayne County prefix, WN-, omitted from local number, dashes indicate discharge not determined; $\mathrm{ft}^{3} / \mathrm{s}$, cubic feet per second]

\begin{tabular}{|c|c|c|c|c|}
\hline \multirow{2}{*}{$\begin{array}{c}\text { identifier } \\
\text { on } \\
\text { plate } 1\end{array}$} & & & & $\frac{\text { Discharge, } \mathrm{ft}^{3} / \mathrm{s}}{\text { Date of measurement }}$ \\
\hline & Latitude & Longltude & Description of location & $9-9-85 \quad 8-14-86$ \\
\hline
\end{tabular}

Reach 1: Silver Rd. to K3, K4

\begin{tabular}{|c|c|c|c|c|c|}
\hline KB1 & $40^{\circ} 48^{\prime} 39^{\prime \prime}$ & $81^{\circ} 58 ' 52^{\prime \prime}$ & $150 \mathrm{ft}$ upstream of Silver Rd. bridge & 11.85 & 6.80 \\
\hline FT & -- & -- & Field tile drain to Killbuck Creek & .10 & - \\
\hline KB2 & $40^{\circ} 48^{\prime} 32^{\prime \prime}$ & $81^{\circ} 58^{\prime} 50^{\prime \prime}$ & $300 \mathrm{ft}$ below Silver Rd. bridge & -- & 6.95 \\
\hline \multirow[t]{4}{*}{ KB3 } & $40^{\circ} 48^{\prime} 25^{\prime \prime}$ & $81^{\circ} 58^{\prime} 49^{\prime \prime}$ & At K3, K4 piezometers & 13.60 & 7.23 \\
\hline & & & Net gains or (losses) along reach, in $\mathrm{ft}^{3} / \mathrm{s}$ & 1.8 & 0.43 \\
\hline & & & \multicolumn{3}{|l|}{ Reach 2: K3, K4 to well field and West Lincoln Way } \\
\hline & & & Discharge contributions from REACH 1 & 13.60 & 7.23 \\
\hline \multirow[t]{2}{*}{$\mathrm{CC} 2$} & & & Inflow to REACH 2 from tributary- & & \\
\hline & & & (Clear Creek) & .51 & .46 \\
\hline KB4 & $40^{\circ} 48^{\prime} 05^{\prime \prime}$ & $81^{\circ} 58^{\prime} 32^{\prime \prime}$ & At Old Mansfield Road & 10.70 & 6.30 \\
\hline \multirow[t]{4}{*}{ KB5 } & $40^{\circ} 47^{\prime} 59^{\prime \prime}$ & $81^{\circ} 58 ' 27^{\prime \prime}$ & At well field near P7 (West Lincoln Way) & 12.35 & 6.99 \\
\hline & & & Net gains or (losses) along reach, in $\mathrm{ft}^{3} / \mathrm{s}$ & (1.8) & $(0.7)$ \\
\hline & & & \multicolumn{3}{|l|}{ Reach 3: West Lincoin Way to State Route 30} \\
\hline & & & Discharge contributions from REACH 2 & 12.35 & 6.99 \\
\hline \multirow[t]{2}{*}{ KT1 } & & & Inflow to REACH 3 from tributary- & & \\
\hline & & & (Cashey Creek) & .87 & 2.38 \\
\hline \multirow[t]{5}{*}{ KB6 } & $40^{\circ} 47^{\prime} 35^{\prime \prime}$ & $81^{\circ} 58^{\prime} 02^{\prime \prime}$ & At State Route 30 Bridge & 12.25 & 9.40 \\
\hline & & & Net gains or (losses) along reach, in $\mathrm{ft}^{3} / \mathrm{s}$ & (1.0) & 0.0 \\
\hline & & \multicolumn{4}{|c|}{$\begin{array}{l}\text { Net gains or (losses) along Killbuck Creek from section KB3 to section KB6 } \\
\text { (area where gradients between stream and shallow aquifer are downward), }\end{array}$} \\
\hline & & & in $\mathrm{ft}^{3} / \mathrm{s}$ & $(2.8)$ & $(0.7)$ \\
\hline & & & in $\mathrm{Mgal} / \mathrm{d}$ & (1.8) & $(0.5)$ \\
\hline
\end{tabular}

and the drum is clamped, the bag is disconnected, and the volume of water that is either gained or lost in the bag is measured. The heads, the 18-in. depth, the rate of volume change (volume per time), and the drum diameter are substituled inlo Darcy's equation. A hydraulic conductivity for the upper 18 in. of the streambed is computed.

\section{Chemical and Isotopic Data}

Samples for chenical and isotopic analyses were collected at 17 wells in the stratified-drift aquifer, at one spring from the drift, and at 4 wells in the shale-sandstone aquifer. The streambed piezometers at four sites on Killbuck Creek were sampled during July and August 1985 to determine the chemical and isotopic character of water beneath the streambed. Samples of surface water were collected at two sites on Killbuck Crcek and at a site on Clear Creek. Samples were analyzed for several categories of constituents including water characteristics, major ions, nutrients, stable isotopes of oxgen and hydrogen, and the radioactive 
Table 4. Gain/loss discharge measurements on selected tributary streams, Killbuck Creek valley, Ohio

[Dashes indicate discharge not determined; $\mathrm{ft}^{3} / \mathrm{s}$, cubic feet per second]

Identfier

on

piate 1
Latitude Longitude
Discharge, $\mathrm{tt}^{3} / \mathrm{s}$

Date of measurement

\begin{tabular}{|c|c|c|c|c|c|}
\hline \multicolumn{6}{|c|}{ Little Killbuck Creek (LKC) drainage } \\
\hline LKB1 & $40^{\circ} 49^{\prime} 11^{\prime \prime}$ & $82^{\circ} 00^{\prime} 36^{\prime \prime}$ & $\begin{array}{l}\text { LKC, above Rathburn Run, } 200 \mathrm{ft} \text { west of } \\
\text { junction of Rt. } 302 \text { and Rt. } 539\end{array}$ & -- & 1.68 \\
\hline LKB2 & $40^{\circ} 49^{\prime} 07^{\prime \prime}$ & $82^{\circ} 00^{\prime} 31^{\prime \prime}$ & Rathburn Run, at last bedrock in channel & -- & .64 \\
\hline LKB3 & $40^{\circ} 49^{\prime} 07^{\prime \prime}$ & $81^{\circ} 59^{\prime} 56^{\prime \prime}$ & LKC, 2,000 ft upstream from Rt. 302 bridge & 1.90 & 2.23 \\
\hline LKB4 & $40^{\circ} 49^{\prime} 03^{\prime \prime}$ & $81^{\circ} 59^{\prime} 33^{\prime \prime}$ & LKC, at Rt. 302 bridge & .41 & .85 \\
\hline LKB5 & $40^{\circ} 49^{\prime} 03^{\prime \prime}$ & $81^{\circ} 59^{\prime} 04^{\prime \prime}$ & LKC, $300 \mathrm{ft}$ above confluence of Killbuck Creek & .10 & .31 \\
\hline & & & $\begin{array}{r}\text { Net loss along reach, in } \mathrm{ft}^{3} / \mathrm{s} \\
\text { in Mgai/d }\end{array}$ & $\begin{array}{l}(1.80) \\
(1.16)\end{array}$ & $\begin{array}{l}(1.92) \\
(1.24)\end{array}$ \\
\hline \multicolumn{6}{|c|}{ Clear Creek (CC) Drainage } \\
\hline $\mathrm{CC1}$ & $40^{\circ} 48^{\prime} 19^{\prime \prime}$ & $81^{\circ} 58^{\prime} 22^{\prime \prime}$ & $\begin{array}{l}\text { Last bedrock in channel, } 1,600 \mathrm{ft} \text { upstream } \\
\text { of confluence with Killbuck Creek }\end{array}$ & 1.05 & 1.30 \\
\hline $\mathrm{CC} 2$ & $40^{\circ} 48^{\prime} 10^{\prime \prime}$ & $81^{\circ} 58^{\prime} 34^{\prime \prime}$ & Confluence with Killbuck Creek & .51 & .46 \\
\hline & & & $\begin{array}{l}\text { Net loss aiong reach, in } \mathrm{ft}^{3} / \mathrm{s} \\
\text { in Mgal/d }\end{array}$ & $\begin{array}{l}(.54) \\
(.35)\end{array}$ & $\begin{array}{l}(.84) \\
(.54)\end{array}$ \\
\hline
\end{tabular}

isotope of hydrogen, tritium. Samples from wells, streams, and the spring were collected approximately monthly during the period September 1984 to August 1985. The suite of chemical and isotopic constituents was chosen to evaluate stream/aquifer interactions, areal and temporal variability in the drift aquifer, and leakage to the stratified-drift aquifer from the adjacent uplands.

Sample collection and preparation/preservation for chemical and isotopic analyses were done according to techniques described by Claassen (1982) and Wood (1976). Samples for determination of dissolved-constituent concentrations were filtered at the field site through membranes with a 0.45 -micrometer pore size. Alkalinity, $\mathrm{pH}$, specific conductance, temperature, and dissolved oxygen were measured at the field site. Chemicalconstituent concentrations were determined by the USGS National Water Quality Laboratory. Isotopic analyses were made by the USGS Isotope Fractionation Laboratory in Reston, Va.

\section{SIMULATED GROUND-WATER FLOW}

A three-layer steady-state finite-difference ground-water-flow model of the Killbuck Creek valley and its adjacent uplands was developed to (1) serve as a case study for the simulation of a buried valley-fill system typical of the glaciated northeastern United States, (2) demonstrate treatment of the adjacent uplands as an active part of the simulation of a valley-fill system, (3) demonstrate the application of a new method, the Variable-Recharge procedure, to simulate areal recharge to a valley-fill system bounded by bedrock uplands, (4) provide estimates of streambed hydraulic properties of Killbuck Creek and its tributaries (Little Killbuck and Clear Creeks) to complement estimates derived from streamflow, streambed-seepage meter, and shallow piezometer and permeameter measurements, and (5) quantify approximately the sources of water to the stratifieddrift aquifer system. 
Table 5. Ground-water/surface-water level relations at streambed piezometers in Killbuck Creek and Clear Creek near Wooster, Ohio, for the period June through September, 1985

[Local number, identifier for piezometer shown on plate 1; Wayne County prefix, WN-, omitted from local number; MM-DD-YY, month-day-year, $\mathrm{ft}$, feet; <, value less than the number shown]

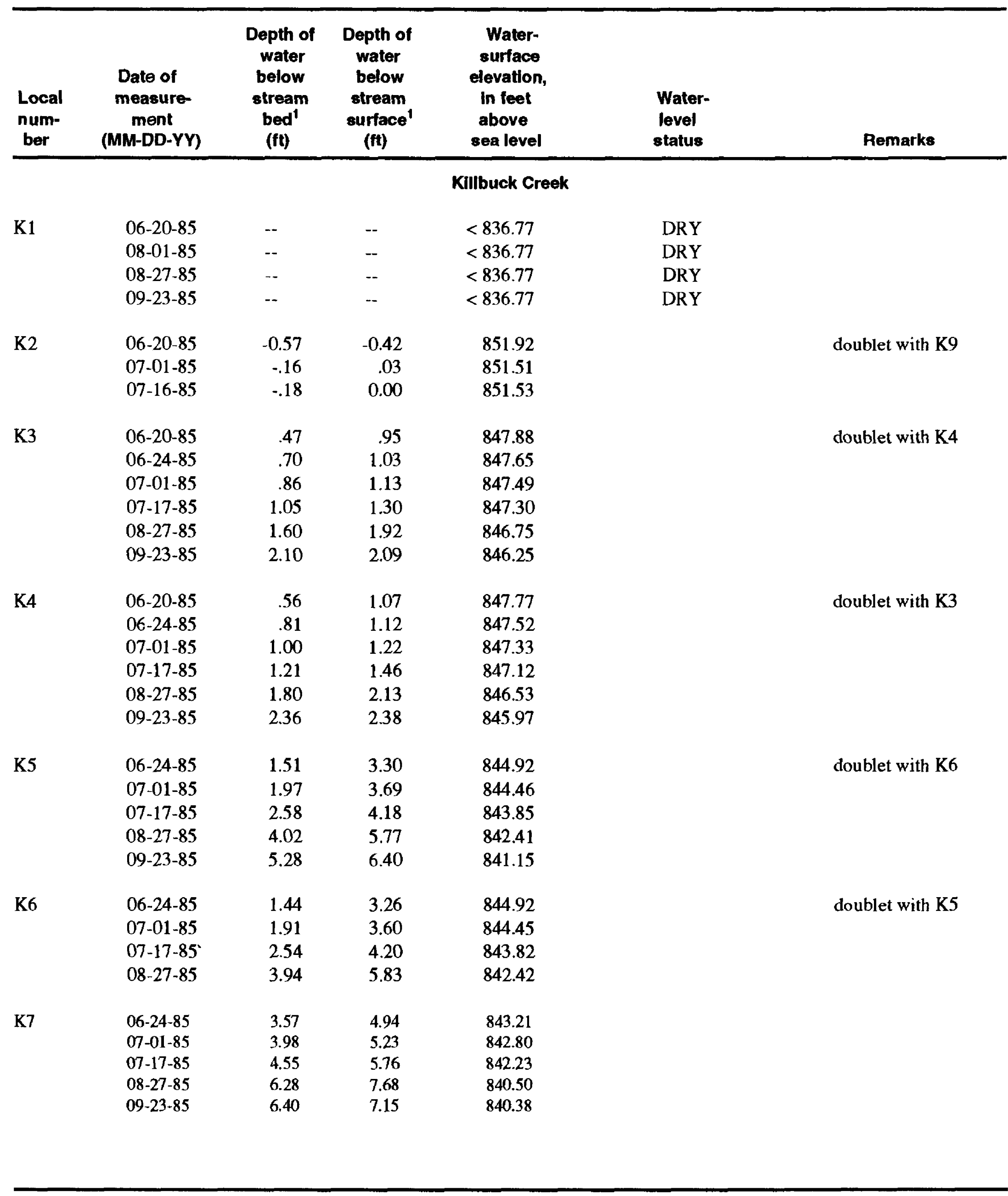

\footnotetext{
${ }^{1}$ A negative value for depth indicates a water level above the reference, either the stream surface or the streambed.
} 
Table 5. Ground-water/surface-water level relations at streambed piezometers in Killbuck Creek and Clear Creek near Wooster, Ohio, for the period June through September, 1985-Continued

\begin{tabular}{|c|c|c|c|c|c|c|}
\hline $\begin{array}{l}\text { Local } \\
\text { num- } \\
\text { ber }\end{array}$ & $\begin{array}{c}\text { Date of } \\
\text { measure- } \\
\text { ment } \\
\text { (MM-DD-YY) }\end{array}$ & $\begin{array}{c}\text { Depth of } \\
\text { water } \\
\text { below } \\
\text { stream } \\
\text { bed }^{\mathbf{1}} \\
\text { (ft) }\end{array}$ & $\begin{array}{c}\text { Depth of } \\
\text { water } \\
\text { below } \\
\text { stream } \\
\text { surface } 1 \\
\text { (ft) }\end{array}$ & $\begin{array}{l}\text { Water- } \\
\text { surface } \\
\text { elevatlon, } \\
\text { in feet } \\
\text { above } \\
\text { sea level }\end{array}$ & $\begin{array}{l}\text { Water- } \\
\text { level } \\
\text { status }\end{array}$ & Remarks \\
\hline \multicolumn{7}{|c|}{ Killbuck Creek-Continned } \\
\hline \multirow[t]{5}{*}{ K8 } & $07-0\}-85$ & - & -- & $<837.86$ & DRY & \\
\hline & $07-02-85$ & -- & -- & $<837.86$ & DRY & \\
\hline & $08-14-85$ & - & -- & $<837.86$ & DRY & \\
\hline & $08-27-85$ & -- & - & $<837.86$ & DRY & \\
\hline & $09-23-85$ & -- & -- & $<837.86$ & DRY & \\
\hline \multirow[t]{4}{*}{ K9 } & $07-02-85$ & -0.18 & 0.18 & 851.37 & & doublet with $\mathrm{K} 2$ \\
\hline & $07-16-85$ & -.13 & .20 & 851.32 & & \\
\hline & $08-28-85$ & -.40 & .30 & 851.59 & & \\
\hline & $09-23-85$ & .15 & .40 & 851.04 & & \\
\hline \multirow[t]{4}{*}{$\mathrm{K} 10$} & $07-03-85$ & 9.40 & 9.46 & 836.6 & & \\
\hline & $07-28-85$ & 10.50 & 10.35 & 835.5 & & \\
\hline & $08-28-85$ & -- & -- & $<831.5$ & DRY & \\
\hline & $09-30-85$ & -- & $\cdots$ & $<831.5$ & DRY & \\
\hline \multicolumn{7}{|c|}{ Clear Creek } \\
\hline \multirow[t]{5}{*}{ C1 } & $06-20-85$ & -- & -- & $<842.57$ & DRY & \\
\hline & $07-01-85$ & -- & -- & $<842.57$ & DRY & \\
\hline & $07-17-85$ & -- & - & $<842.57$ & DRY & \\
\hline & $08-27-85$ & -- & -- & $<842.57$ & DRY & \\
\hline & 09-23-85 & - & -- & $<842.57$ & DRY & \\
\hline
\end{tabular}

The description of simulation methodology in this report is limited to (1) details concerning model design, assignment of hydraulic properties, and the calibration process, and (2) a brief description of the Variable-Recharge procedure.

\section{Modeling Strategy}

The steady-state nodel was calibrated to conditions prevailing during the fall of 1984 . Plausibility of the steady-state model hydraulic properties was tested by a transient simulation of an 11-day recliarge event that occurred in late February 1985. The modular code of McDonald and Harbaugh (1988), with the addition of the new procedure to simulate areal recharge with the Variable-Recharge procedure, was used for all simulations.

\section{Steady-State Simulation}

Water levels in 13 observation wells, all located in the vicinity of the north well field (pl. 1), were measured by the USGS (table 6) (in the supplemental section in back of this report) from July 1984 to September 1985, at time intervals ranging from about one week to two months, and by Springer (1987) from April to December 1986, at about onemonth intervals. A series of test wells were drilled in the south well field area, under the aegis of the City of Wooster, beginning in October 1983 (Mayhew, 1985). Springer (1987) measured water levels in 25 of these wells from June to December 1986, at about one-month intervals. The hydrographs of wells in the north well field (fig. 3) show that during the fall of 1984 water levels were relatively stable, indicating that the aquifer system was probably in an approximate steady-state condition. 

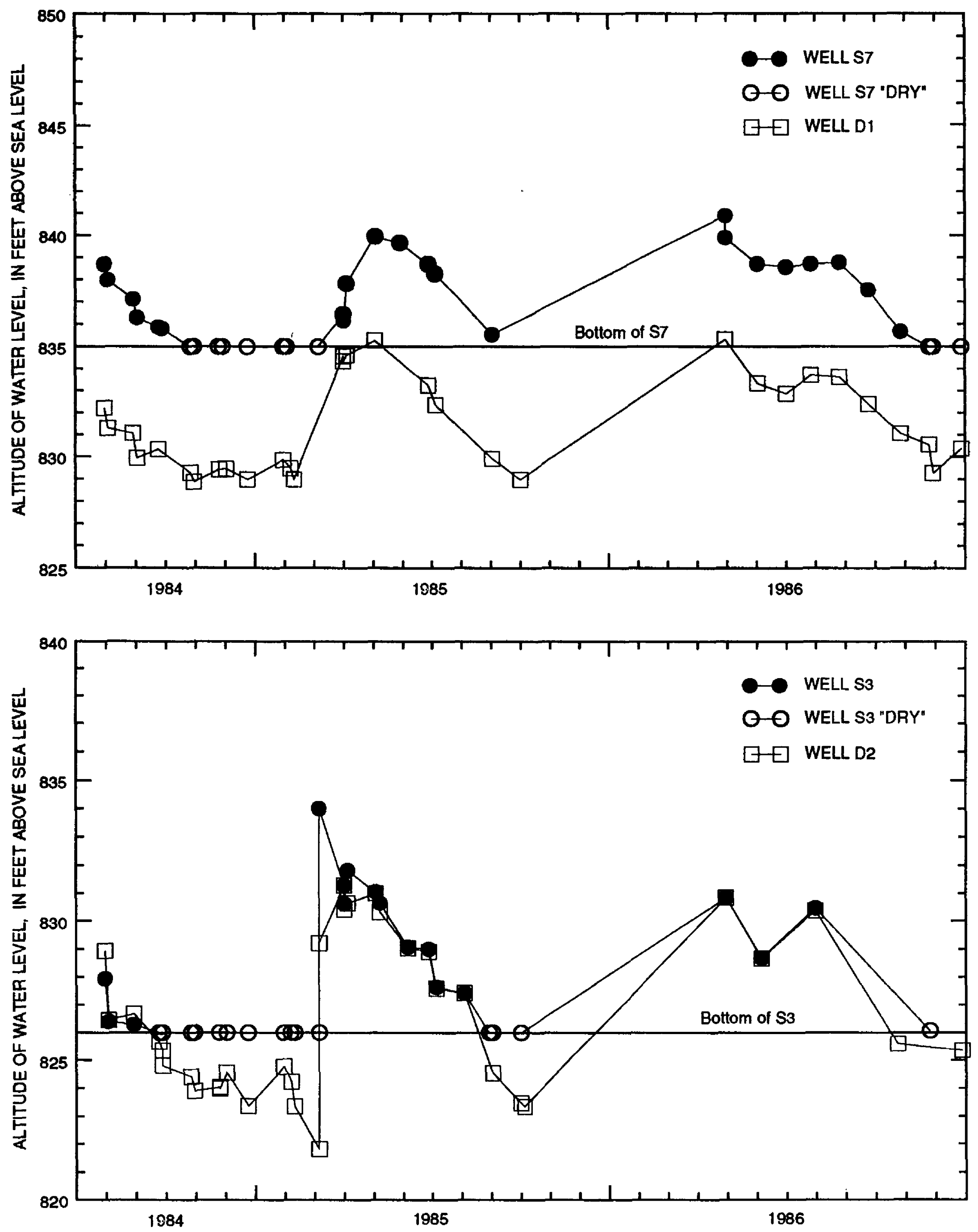

Figure 3. Hydrographs of north well field observation wells D1 through S13 from July 1984 to December 1986. (Data after April 1986 from Springer, 1987.) 

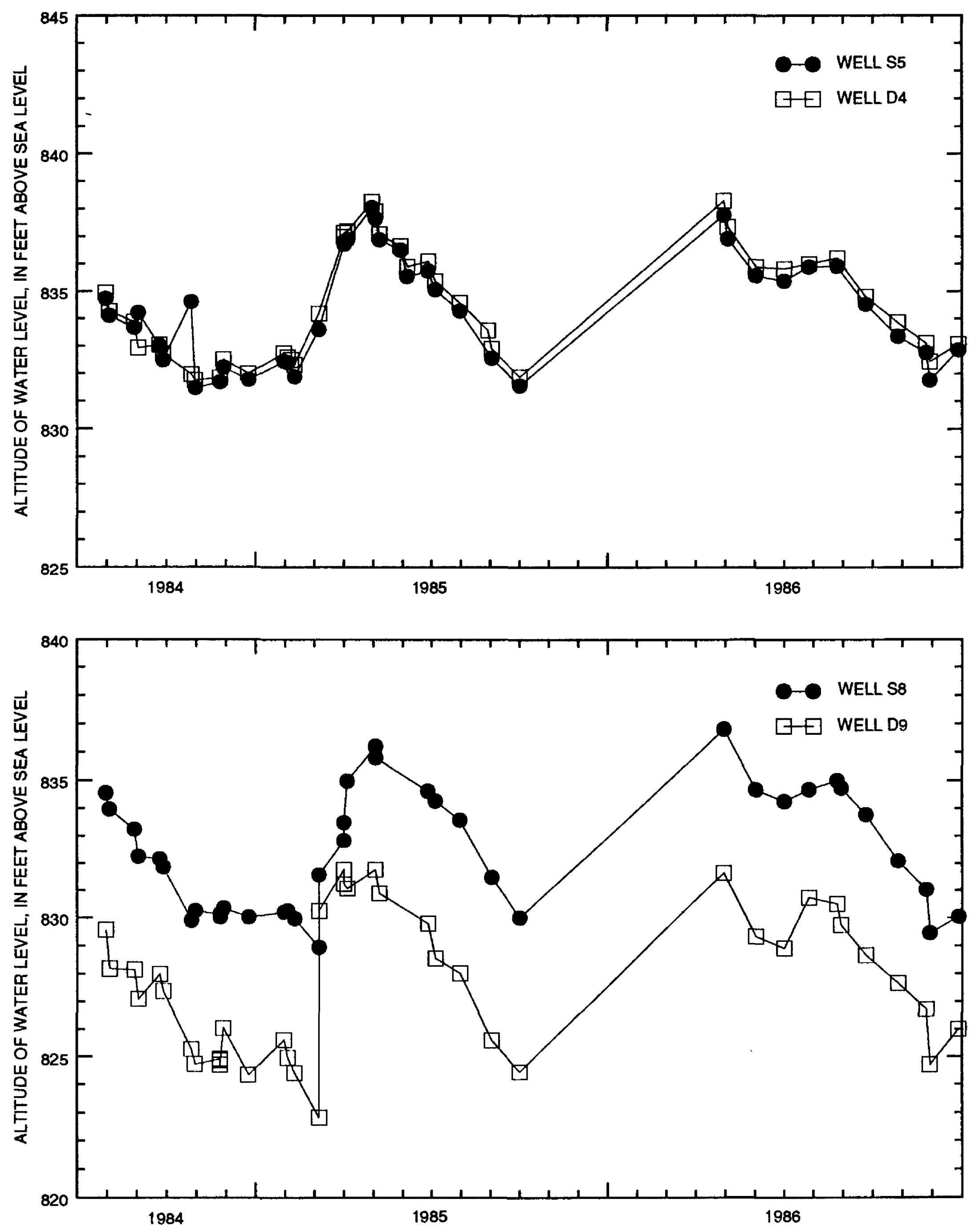

Figure 3. Hydrographs of north well field observation wells D1 through S13 from July 1984 to December 1986--Continued. 

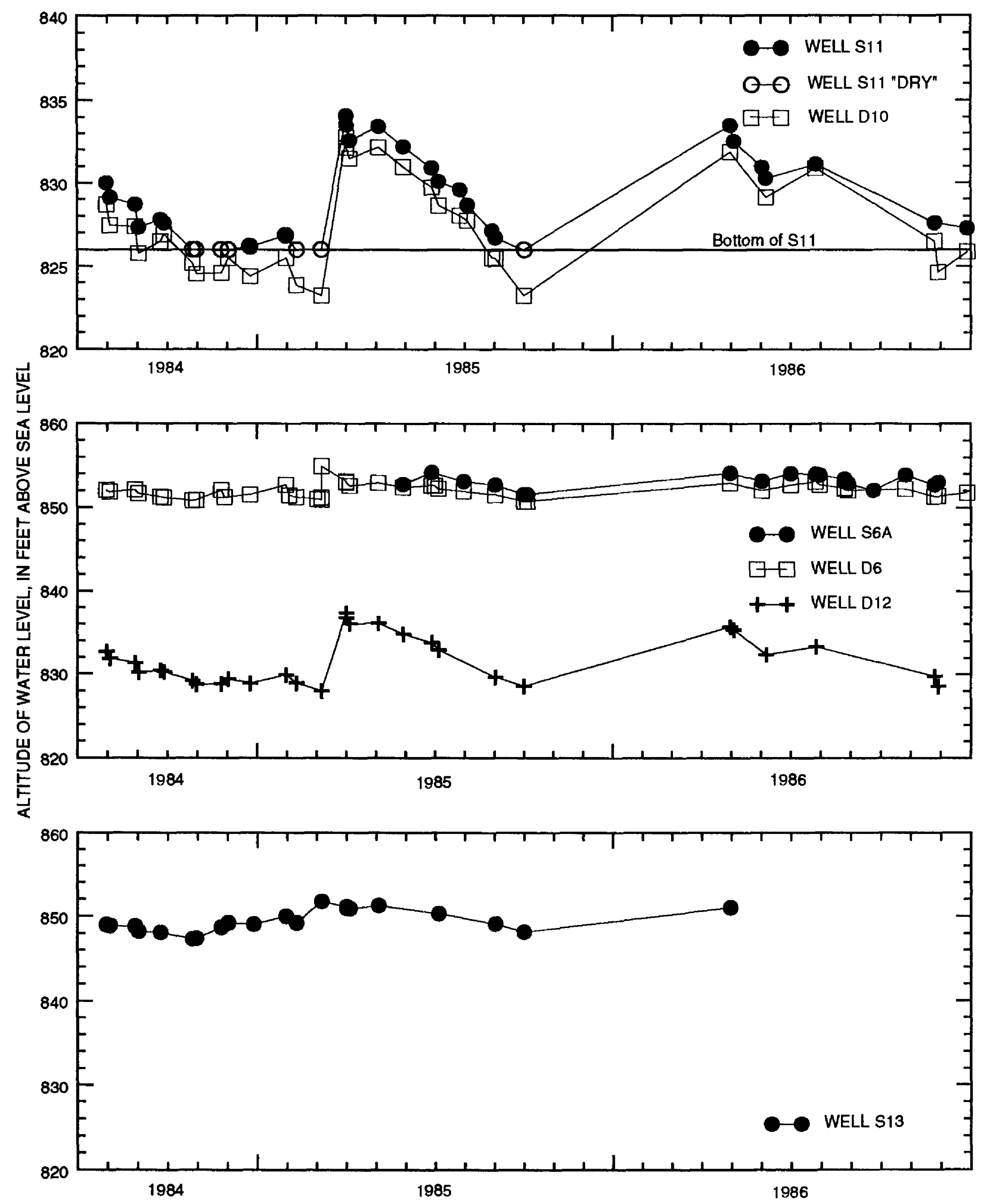

Figure 3. Hydrographs of north well field observation wells D1 through S13 from July 1984 to December 1986--Continued. 
Therefore, the average value of water levels measured during the fall of 1984 was assumed to be representative of the steady-state condition. Furthermore, in the north well field observation wells, water levels measured in November 1986 were relatively close in magnitude to the fall 1984 average water levels (fig. 3), thereby indicating similar hydrologic conditions during these time periods. Consequently, it was assumed that the November 1986 water levels could be used for calibration of the fall 1984 steady-state model in the vicinity of the south well field. Other data that were available for calibration of the steady-state simulation included stream gains and losses in Clear Creek, Little Killbuck Creek, and Killbuck Creek, water levels from Killbuck Creek streambedpiezometers, and water levels in several wells in the uplands (pl. 1)

\section{Transient Simulation}

In response to recharge derived from a rapid melting of $18 \mathrm{in}$. of snow beginning on 23 February 1985, water levels rose several feet throughout the north well field (table 7).

Table 7. Recharge-induced changes in ground-water conditions at selected wells near the north well field, February 1985, Wooster, Ohio

[Wayne County prefix, WN-, omitted from local number, D, deepscreened greater than 50 feet below land surface; $S$, shallow-screened in upper gravels, less than 35 feet below land surface; $P$, deep production-screened greater than 50 feet below land surface; DRY indicates a water level beneath the bottom of the well]

\begin{tabular}{|c|c|c|}
\hline \multirow{2}{*}{$\begin{array}{l}\text { Local } \\
\text { number }\end{array}$} & \multicolumn{2}{|c|}{ Water level. in feet above sea level } \\
\hline & February 21-22 & February 25-26 \\
\hline $\mathrm{D} 2$ & 821.76 & 829.15 \\
\hline s3 & DRY & 834. ${ }^{1}$ \\
\hline D4 & $832.32(1 / 30 / 85)$ & 834.17 \\
\hline S5 & $831.88(1 / 30 / 85)$ & 833.60 \\
\hline D6 & 851.18 & 854.94 \\
\hline s7 & DRY & DRY $Y^{1}$ \\
\hline S8 & 828.95 & 831.56 \\
\hline D9 & 822.82 & 830.25 \\
\hline P3 & 813.37 & $826.46(3 / 1 / 85)$ \\
\hline P4 & 808.43 & $817.60(3 / 1 / 85)$ \\
\hline P5 & 819.30 & -- \\
\hline P6 & 820.51 & $831.09(3 / 1 / 85)$ \\
\hline P7 & 820.20 & $830.86(3 / 1 / 85)$ \\
\hline P8 & 822.16 & $832.74(3 / 1 / 85)$ \\
\hline
\end{tabular}

\footnotetext{
${ }^{T}$ Well venting gases at a significant rate.
}

For example, the water levels in deep well D2A (pl. 1) rose about $11 \mathrm{ft}$ over a six-day period (fig. 4). Killbuck Creek rose at least $7 \mathrm{ft}$ at Silver Road and Old Mansfield Road over a 2- to 3-day period. Presnowmelt ground-water levels were about 1 to $2 \mathrm{ft}$ lower than the average levels prevailing during the fall of 1984 (figs. 3 and 4). Thus, between the fall 1984 assumed steady-state condition and the rapid recharge event of February 1985, there was a period of little or no recharge resulting in a decline in water levels. Nevertheless, for the purpose of providing an approximate confirmation of the steady-state model, it was decided to ignore the period of waterlevel decline and to simulate the rapid recharge event by use of the fall 1984 steady-state heads as the initial condition of an 11-day (23 February through 5 March 1985) transient simulation.

\section{Simulation of Recharge by Variable- Recharge Procedure}

Areal recharge was simulated by a procedure developed as part of the NEGA RASA. The method, termed the Variable-Recharge procedure, conforms to the modular structure of the USGS ground-water-flow model (McDonald and Harbaugh, 1988) and is designed primarily for simulation of a stratified-drift aquifer bounded by bedrock uplands that are an active part of the model. A brief narrative of the procedure follows.

In the USGS ground-water-flow model (McDonald and Harbaugh, 1988), recharge is simulated by specifying an areal distribution of recharge which is applied to active model-nodes, irrespective of the model head-distribution. The basic premise of the Variable-Recharge procedure is that recharge can occur only when the hydraulic head in shallow earth materials is below land surface. Conversely, if the hydraulic head is at or above land surface, recharge cannot occur and ensuing precipitation will be rejected. In addition, when the head is at or above land surface, outward seepage may occur. Thus, the procedure is conceptually similar to the variable source areaoverland flow concept, which postulates that overland flow occurs when soils are saturated by a rising water table (Dunne and Black, 1970), and to the ground-water-flow-model code of Potter and Gburek (1987) wherein outward seepage is 


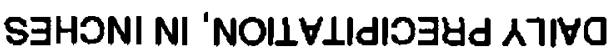

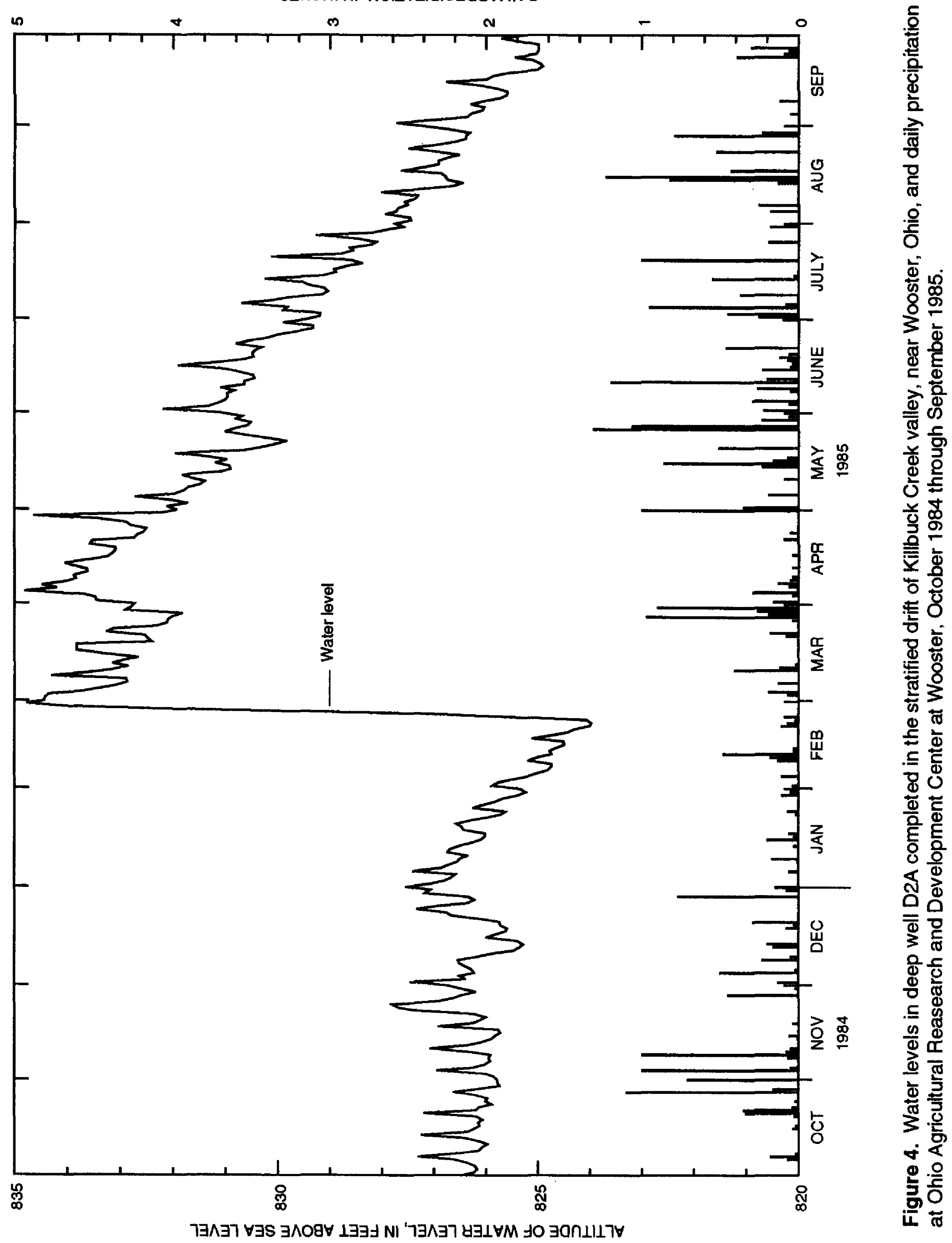


calculated when the water table reaches land surface. When recharge is rejected or seepage occurs on upland hillsides, the rejected recharge and seepage becomes surface runoff that may eventually be a source of recharge to a valley-fill aquifer, either as channeled flow in tributary streams that cross the valley fill, or as unchanneled runoff that infiltrates when it reaches the valley fill at the base of the hillside. Unchanneled runoff is defined as runoff from hill slopes that reaches the valley by way of sheetflow, shallow subsurface flow, and small rills.

The Variable-Recharge procedure requires the following information:

(1) Average land-surface elevation for each active model node of the top model layer.

(2) Division of the entire area to be modeled, including uplands, into a set of upland surfacedrainage subbasins and topographically low areas (Variable-Recharge-zone array). Surface-drainage subbasins in which surface runoff is calculated and redistributed to other parts of the model are assigned a nonzero number. Areas that are topographically low and in which surface runoff is not redistributed are assigned a zero zone number designation and usually include the main valley of a valley-fill system. They may also include topographically low areas in the uplands, where surface runoff enters streams whose flow does not cross the modeled area or is not treated quantitatively in the model.

(3) For each upland subbasin, an estimate of the proportion of upland runoff (suinmation of upland rejected recharge and seepage) that reaches the valley floor as channeled flow.

(4) If part of the upland runoff reaches the valley floor as channeled flow, specification of the model node-location, streambed conductance, stream stage, and elevation of the top and bottom of the streambed for each node along the valley floor that contains a stream reach.

(5) Specification of the model location of nodes, along the valley wall, that receive upland unchanneled runoff.
(6) Estimate of the quantity of water available for recharge (WAFR) for a particular time period. WAFR (in units of length, $L$ ) is the water potentially available to recharge the ground water (in inches) and may be computed from the relation (modified from Lyford and Cohen, 1988, p. 40):

$W A F R=P-E T+S N m-S N S \pm S M,(\mathrm{~L})$

where, $\mathbf{P}$ is precipitation, ET is evapotranspiration of moisture above the saturated zone, $\mathrm{SN}_{\mathrm{m}}$ is snowmelt, $\mathrm{SN}_{\mathrm{s}}$ is snow held in storage, and $\mathrm{SM}$ is the change in soil moisture in the unsaturated zone. If evapotranspiration of soil moisture (ET) exceeds precipitation (P), WAFR is zero, and soil moisture (SM) is depleted. If precipitation exceeds evapotranspiration, then soil moisture addition occurs. Before this addition can become water available for recharge, any soil moisture deficits, accumulated over time, must be replenished.

The WAFR, calculated for the entire model by equation 1 , may be modified for all nodes within each of the surface drainage subbasins by specifying a multiplication factor for each subbasin.

For use in modeling, water available for recharge is expressed as a flow rate for a finitedifference node $i, j, k$, as

$$
R_{w a}=\left(\frac{W A F R}{t} \Delta r \Delta c\right)_{i, j, k},\left(\mathrm{~L}^{3} / \mathrm{t}\right)
$$

where $\Delta \mathrm{r}$ and $\Delta \mathrm{c}$ are the cell dimensions in the row and column directions, respectively; $\Delta \mathrm{r} \Delta \mathrm{c}$ is the area of the cell $i, j, k$; and $t$ is the length of the time period for which water available for recharge is computed. In the McDonald and Harbaugh (1988) indexing system for finite-difference nodes, if $I, J$, $\mathrm{K}$ are the total number of model rows, columns, and layers, respectively, then $\mathrm{i}=1,2, \ldots \mathrm{I} ; \mathrm{j}=1,2, \ldots \mathrm{J}$; and $k=1,2, \ldots K$. In the Variable-Recharge procedure, the layer index $(\mathrm{k})$ is the topmost active model layer to which the $R_{w a}$ is applied. 
The Variable-Recharge procedure is implemented each time the ground-water-flow finite-difference equation is formulated (that is, at each iteration) by comparing the hydraulic head in each node with land-surface elevation. The amount of recharge, rejected recharge, and surface runoff for a particular node depends on the elevation of the simulated hydraulic head $\left(\mathrm{H}_{\mathrm{a}}\right)$ relative to land surface $\left(\mathrm{H}_{\mathrm{s}}\right)$ and to a pseudo land surface $\mathrm{H}_{\mathrm{s}}^{\prime}$ defined to be $\mathrm{H}_{\mathrm{s}}$-df, where df is a specified depth factor. Three types of conditions are simulated by the Variable-Recharge procedure. These in turn, govern the amount of recharge $(R)$, rejected recharge (Rej), secpage $\left(S_{o}\right)$, and surface runoff (SR) that occurs. In particular,

Type 1 (full recharge, no rejected recharge, no surface runoff, no seepage)

$$
\left.\begin{array}{c}
R=R_{w a} \\
R e j=0 \\
S R=0 \\
S_{o}=0
\end{array}\right\} \text { if }\left(H_{a} \leq H_{s}^{\prime}\right)
$$

Type 2 (partial recharge, partial rejected recharge, surface runoff, no seepage)

$$
\left.\begin{array}{c}
R=R_{w a} \frac{\left(H_{s}-H_{a}\right)}{d f} \\
S R=R e j=R_{w a}-R \\
S_{o}=0
\end{array}\right\} \text { if }\left(H_{s}^{\prime}<H_{a}<H_{s}\right) \text { and }(d f>0),\left(\mathrm{L}^{3} / \mathrm{t}\right)
$$

Type 3 (no recharge, full rejected recharge, and possible outward seepage, surface runoff)

$$
\left.\begin{array}{c}
R=0 \\
R e j=R_{w a} \\
S R=R e j+S_{o}=R_{w a}+S_{o}
\end{array}\right\} \text { if }\left(H_{a} \geq H_{s}\right)
$$

In equations $3 a$ through $3 \mathrm{c}$, the node location $\mathrm{i}, \mathrm{j}, \mathrm{k}$ for all terms is implied. In implementing the Variable-Recharge procedure, occasional numerical instabilities arise during the solution iteration process, thereby preventing convergence to a suitable solution for head. The pseudo land surface $\left(\mathrm{H}_{\mathrm{s}}^{\prime}\right)$ and depth factor $(\mathrm{d} f)$ are computational devices intended to minimize such instabilities. Although the depth factor and pseudo land surface have no physical meaning for some hydrologic settings, the manner in which the depth factor affects recharge can be related to a physical process. For example, suppose that the land surface area represented by a model node contains microtopography with relief similar to the depth factor. As the water table rises to the elevation of the low places, recharge in these areas will cease, outward seepage may occur, and surface rills may form. However, recharge can still occur between the low places. Thus, in this setting, recharge will tend to be less than if the microtopography was not present. Similarly, the depth factor acts to reduce recharge as described by equation $3 \mathrm{~b}$. Experience has shown that use of a nonzero depth factor (df), usually $1 \mathrm{ft}$ or less, in equations $3 \mathrm{a}$ and $3 \mathrm{~h}$ will, in most cases, minimize these instabilities. If the depth factor is zero, then $\mathrm{H}_{\mathrm{s}}=\mathrm{H}^{\prime}$ s and only equations $3 \mathrm{a}$ and $3 \mathrm{c}$ apply.

In equation $3 c$, the term $S_{0}$ represents outward seepage that is assumed to occur if the sum of the ground-water flows between the node and the five adjacent nodes is positive. This is determined by calculating the provisional quantity for node $\mathrm{i}, \mathrm{j}, \mathrm{k}$,

$$
\begin{aligned}
& \text { So }^{*}=q_{i, j-1 / 2, k}+q_{i, j+1 / 2, k}+q_{i-1 / 2, j, k}+ \\
& q_{i+1 / 2, j, k}+q_{i, j, k+1 / 2} \quad\left(L^{3} / t\right)
\end{aligned}
$$


where the q terms represent ground-water flow between node $\mathrm{i}, \mathrm{j}, \mathrm{k}$ and the 5 adjacent nodes (eqs. 10 through 13 and eq. 1'5 of McDonald and Harbaugh, 1988). If $S_{0}{ }^{*}$ is positive, then the net flow from adjacent areas is into the node, and this net flow is designated as outward seepage by setting $\mathrm{S}_{\mathrm{o}}=\mathrm{S}_{\mathrm{O}}{ }^{*}$. In addition, the node in question is set to a constant head, equal to land-surface elevation. That is, $\mathrm{H}_{\mathrm{a}}=\mathrm{H}_{\mathrm{s}}$ if $\mathrm{S}_{\mathrm{o}}{ }^{*} \geq 0$. If the net ground-water flow between node $\mathrm{i}, \mathrm{j}, \mathrm{k}$ and adjacent cells is away from the node $\left(S_{0}{ }^{*}<0\right)$, outward seepage does not occur, the node continues to be active, and the provisional term $S_{o}{ }^{*}$ is not used. If the flow between a seepage node and adjacent nodes reverses due to changing hydraulic conditions, the constant-head condition is released and the node becomes active.

The amount of surface runoff available to recharge the valley for each upland subbasin is obtained at each iteration by summing the rejected recharge and outward seepage for all nodes within each upland subbasin (Variable-Recharge zone) and is distributed according to the information specified in items (3), (4) and (5) above. The unchanneled runoff from each subbasin is divided equally among valley nodes designated to receive runoff from that subbasin and is applied as additional water available for recharge (equations 1 and 2). The channeled runoff from each subbasin is divided equally among each tributary stream designated to receive channeled runoff from that subbasin. The computed channeled runoff is applied as the initial streamflow in the upstream node of each tributary stream. Depending on the relation between streamsurface altitude and the hydraulic head in the aquifer beneath the stream, the streams may gain or lose water as they flow across the valley floor. At present, the Variable-Recharge procedure does not provide for any downstream tributary streamflow to be added to its receiving stream. This may pose a problem in simulations where the receiving stream is ephemeral.

\section{Model Design}

The ground-water-flow model was designed to specifically address the objectives outlined in the beginning of this section. The following description of the model grid, its lateral boundaries, and the vertical discretization of the model is requisite to understanding how accurately the model serves to simulate the real system.

\section{Model Grid and Lateral Boundaries}

For this study, the area in and around the Wooster waterworks (north well field) was the primary area of interest. As shown in plate 2, the model grid was oriented northwest to southeast along the trend of the valley in this vicinity. The model grid consists of 84 rows and 77 columns and has a non-uniform spacing that ranges from 150 to $750 \mathrm{ft}$. The finer grid-spacing corresponds with the location of the north well field production wells.

In Killbuck Creek valley, the northerly model boundary was placed about $6,000 \mathrm{ft}$ north of the confluence of Little Killbuck Creek and Killbuck Creek and about $13,000 \mathrm{ft}$ north of the north well field (pl. 2). As demonstrated by model sensitivity analyses, this boundary is sufficiently far from the north well field that inaccuracies of applied boundary conditions will have a minimal effect on the flow systems of interest. The southerly model boundary was located to include the south well field near the confluence of Killbuck and Apple Creeks, but is only 4,000 ft south of production well PS2. Simulations in which the applied boundary condition was varied showed that it can significantly influence the flow field near the south well field.

In the uplands, the model is bounded by zeroflow boundaries along prominent topographic divides assumed to be coincident with groundwater divides, or parallel to flow lines directed toward Killbuck Creek valley. Nodes in zones A through $\mathrm{D}$ (pl. 2) were excluded from the active model. In zone D, ground water flows to Killbuck Creek downstream from the study area. Zones A, B, and $C$ are parts of the watersheds of large tributary streams that enter Killbuck Creek within the model area. Most of ground-water flow in the watersheds discharges to these tributary streams so that the hydraulic effect of zones A, B, and C on the valley fill is primarily through the interaction of the tributary streams with the valley aquifer as described in the section on hydraulic properties of streams and drains (to follow). This interaction was simulated by the Stream Package of Prudic (1989). 


\section{Vertical Discretization}

The Killbuck Crcek valley sediments consist of a heterogeneous mix of stratified drift deposited on, and adjacent to, the shales and sandstones of the Cuyahoga and Logan formations that form the uplands. The vertical heterogeneity of both the valley sediments and the upland bedrock was approximated, for simulation purposes, by discretization into three layers (fig. 2B).

The topmost layer (layer 1) within the valley generally represents lacustrine sediments, which consist primarily of relatively low-permeability silt and clay with small amounts of fine sand. Layer 1 also contains high-permeability alluvialfan deposits near Little Killbuck and Clear Creeks. In the uplands, layer 1 is a composite of shale and sandstone, overlain by till. It is treated as being unconfined and, as such, requires specification of the altitude of the layer bottom. The bottom altitude was developed by subtracting estimated layer thickness ranging from $251035 \mathrm{ft}$, within the valley, and 45 to $75 \mathrm{ft}$, in the uplands, from land-surface elevation.

Layers 2 and 3 within the valley represent material that ranges in composition from silty clay to gravel (Breen, 1988, p. 110). The upland extension of layers 2 and 3 consists of sandstone and shale (fig. 2). Both layers are confined by layer 1 . For the computation of layer 2 and 3 transmissivities, the thickness of each layer within the valley was taken to be $20 \mathrm{ft}$ north of the confluence of Apple and Killbuck Creek and $30 \mathrm{ft}$ to the south. Because of a lack of detailed knowledge of the upland geology, a transmissivity value of $15 \mathrm{ft}^{2} / \mathrm{d}$ was uniformly assigned to the upland segments of model layers 2 and 3. This transmissivity is based on an assumed thickness of $50 \mathrm{ft}$ and assumed horizontal hydraulic conductivity of $0.3 \mathrm{ft} / \mathrm{d}$. Till underlies model layer 3 in the valley (fig. 2), which in turn overlies the bedrock. Flow below layer 3 was assumed to be negligible, so that the botton of layer 3 was taken to be a zero-flow boundary.

Conceptually, the vertical hydraulic connection between layers 1 and 2 is primarily dependent on the vertical hydraulic conductivities of materials within layers 1 and 2 , as opposed to the hydraulic properties of a distinct confining layer. In some locations gravel deposits of layers 2 and 3 are vertically continuous, whereas in other locations they are separated by low-permeability silt and clay. Thus, the vertical hydraulic connection between layers 2 and 3 is, in some places, dependent on the vertical hydraulic conductivities of layer 2 and 3 materials, and in other areas controlled by the vertical hydraulic conductivity and thickness of a distinct confining layer. For the simulation, variability in transmissivity and in vertical leakance was facilitated by developing zones of varying hydraulic conductivity as described in the section "Hydraulic Conductivity and Vertical Leakage."

\section{Model Input}

The input required for the ground-water-flow model includes specification of boundary fluxes, stresses on the system (such as pumping). properties of streams and drains, and aquifer characteristics. The Variable-Recharge procedure requires additional data concerning the water available for recharge, land-surface elevations, designation of upland variable-recharge zones, possible modification of water available for recharge and runoff in urban zones, and disposition of upland runoff. For the transient model, definition of the stresses prevailing during the simulated period and the storage properties of the valley fill and uplands are required: These input data are further described in the following section.

\section{Boundary Fluxes and Pumping Rates}

Ground-water flow across the northem boundary of the model within the valley and ground-water flow emanating from the valleys of Clear and Apple Crecks were simulated by applying nonzero fluxes (pl. 2 and table 8). They were computed from Darcy's Law by use of representative horizontal hydraulic conductivities, model-cell dimensions, and an assumed head gradient perpendicular to the boundaries of 1-ftper-node spacing. Under nonpumping conditions, there is probably a southerly flow within the valley across the southern edge of the model (pl. 1). Pumping from well PS2 would induce northerly flow from the south, however, resulting in a groundwater divide in the valley fill somewhere south of well PS2. Consequently, for the steady-state simulation, it was assumed that a divide is located 
Table 8. Boundary fluxes and pumping rates for the steady-state simulation

[ft ${ }^{3} / s$, cubic feet per second]

\begin{tabular}{|c|c|c|c|c|}
\hline Feature & Layer & $\begin{array}{l}\text { Model node(s) } \\
\text { (row, column) }\end{array}$ & $\begin{array}{c}\text { Flux } \\
\text { per node } \\
\left(\mathrm{ft}^{3} / \mathrm{s}\right) \\
\end{array}$ & $\begin{array}{c}\text { Layer or } \\
\text { group } \\
\text { totals } \\
\left(\mathrm{ft}^{3} / \mathrm{s}\right) \\
\end{array}$ \\
\hline \multicolumn{5}{|c|}{ Boundary fluxes } \\
\hline \multirow[t]{7}{*}{$\begin{array}{l}\text { Killbuck Creek, } \\
\text { northern valley }\end{array}$} & $\begin{array}{l}1 \\
1\end{array}$ & $\begin{array}{l}(1,41)-(1,42) \\
(1,43)-(1,50)\end{array}$ & $\begin{array}{l}0.00174 \\
\underline{0.00230}\end{array}$ & 0.020 \\
\hline & 2 & $(1,41)-(1,42)$ & 0.00578 & \\
\hline & 2 & $(1,43)-(1,46)$ & 0.019 & \\
\hline & 2 & $(1,47)-(1,50)$ & $\underline{0.0077}$ & 0.118 \\
\hline & 3 & $(1,41) \div(1,42)$ & 0.00578 & \\
\hline & 3 & $(1,43)-(1,46)$ & 0.00963 & \\
\hline & 3 & $(1,47)-(1,50)$ & $\underline{0.0077}$ & 0.081 \\
\hline Clear Creek valley & 1 & $(28,44)-(29,44)$ & $\underline{0.001}$ & 0.002 \\
\hline \multirow[t]{7}{*}{ Apple Creek valley } & 1 & $(73,64)$ & 0.002 & \\
\hline & 1 & $(74,64)-(76,74)$ & 0.003 & \\
\hline & 1 & $(77,64)$ & $\underline{0.0046}$ & 0.016 \\
\hline & 2 & $(73,64)$ & 0.02 & \\
\hline & 2 & $(74,64)-(76,74)$ & 0.03 & \\
\hline & 2 & $(77,64)$ & $\underline{0.046}$ & 0.156 \\
\hline & & & Totai & 0.39 \\
\hline \multicolumn{5}{|c|}{ Pumping rates } \\
\hline \multirow[t]{5}{*}{ North well field } & 3 & $(34,33)$ & -1.25 & \\
\hline & 3 & $(35,34)$ & -1.25 & \\
\hline & 3 & $(37,35)$ & -1.25 & \\
\hline & 3 & $(38,35)$ & -1.25 & \\
\hline & 3 & $(39,37)$ & $\underline{-0.5}$ & -5.5 \\
\hline \multirow[t]{4}{*}{ South well field } & 3 & $(72,54)$ & -1.21 & \\
\hline & 3 & $(74,52)$ & -0.45 & \\
\hline & 3 & $(78,50)$ & $\underline{-1.35}$ & -3.01 \\
\hline & & & Total & -8.5 \\
\hline
\end{tabular}


near the southern edge of the model and acts as a zero-flow boundary. The pumping rates used in the steady-state simulation (table 8) represent average rates for the north well field during the fall of 1984, and average rates for the south well field during the 1986 water year ${ }^{1}$ (Springer and Bair, 1990).

\section{Variable Recharge Data}

As previously discussed, the Variable-Recharge procedure requires the water available for recharge (eq. 1) expressed as a flow rate (eq. 2) for each active node of model layer 1 , an array of landsurface elevations, a zone array that delineates upland subbasins and the valley fill, and information that characterizes how the water available for recharge and upland surface runoff is to be distributed. These data were developed as follows.

\section{Water Available For Recharge}

Each of the terms for calculation of water available for recharge (WAFR, eq. 1) were estimated for successive periods of a month or less from 1 January 1984 through 5 March 1985 (table 9). The total WAFR for the period October through December 1984 was 3.27 in. This quantity was converted to an equivalent continuous rate of $3.43 \times 10^{-8} \mathrm{ft} / \mathrm{s}$ for use in the steady-state simulation. The flow rate of water available for recharge for a particular node was then obtained by multiplying by the nodal surface area (eq. 2 ).

\section{Land-Surface Elevation}

The array containing land-surface elevation for each of the unequally spaced model nodes was obtained by initially.estimating average landsurface elevation within blocks of size $750 \mathrm{ft}$ by $750 \mathrm{ft}$, from USGS topographic maps of the area. A bicubic-spline interpolation method (Davis and Kontis, 1970; Kontis and Mandle, 1980) was applied to the uniformly spaced values to produce landsurface elevation, within the non-uniformly spaced model-blocks (pl. 2). A contour represen-

\footnotetext{
${ }^{\mathrm{J}} \mathrm{A}$ water year for 1986 is defined as beginning on October 1 , 1985, and ending on September 30, 1986.
}

tation of the resultant land-surface elevation is given in plate 3 .

\section{Upland Variable-Recharge Zones}

The delineation of upland topography into subbasins or Variable-Recharge zones is slown in plate 2. For each of the subbasins, numbered 1 through 15 , that are entirely within the model area, it was assumed that any surface runoff and groundwater flow occurring within these zones moves toward upland tributary streams or to adjacent portions of the Killbuck Creek valley wilhin the model area. Surface runoff from upland subbasins A, B, and C drains toward Little Killbuck Creek, Clear Creek, and Apple Creek, respectively, and it was assumed that most of the ground-water flow also discharges to those streams. Consequently, model nodes within these subbasins were treated as being inactive; however, the portion of each tributary stream that flows onto the Killhuck Creek valley (pls. 1 and 2 ) was explicitly simulaled by the Stream Package of Prudic (1989). In addition, underflow within the Clear Creek and Apple Creek valleys was simulated by nonzero specified fluxes, at the edge of Killbuck Creek valley (pl. 2). During the early stages of simulation, underflow was also applied in the Little Killbuck Creek valley but was removed because of model insensitivily. Surface runoff and ground-water flow within zone D was assumed to drain away from the portion of the Killbuck Creek valley within the model area, so that zone D nodes are inactive. Upland nodes with zone numbers 1 through 15 , together with all active nodes in topographically low areas, designated as zone-zero, constitute the Variable-Recharge zone array (pl. 2).

\section{Reduction of Water Available for Recharge and Runoff in Urban Areas}

Paved areas, storm sewers, roadside ditches, and drainage systems around buildings, all of which commonly accompany urban development in uplands, are likely to reduce recharge and intercept unchanneled upland runoff. Therefore, the Variable-Recharge procedure allows for the rate of water available for recharge to be modified for each zone and (or) the proportion of surface runoff that may recharge aquifers downslope to be specified 


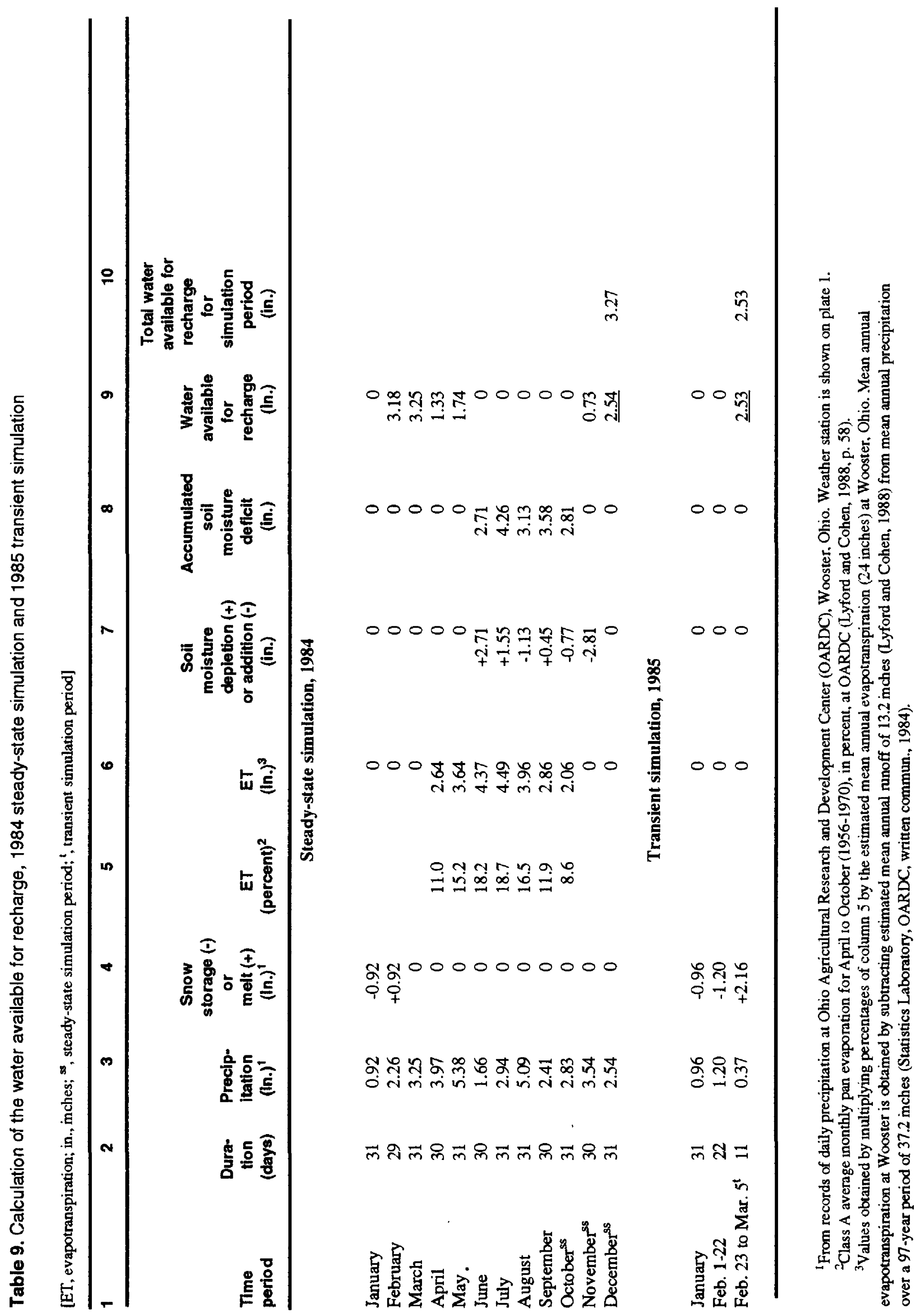


differently for each zone. Much of zone 10 (pl. 2) of the model has urban land use. Therefore, the calculated rate of water available for recharge of $3.43 \times 10^{-8} \mathrm{ft} / \mathrm{s}$ was arbitrarily reduced by 50 percent in this zone only, as was the percentage of surface runoff that flows downslope to the valley (table 10, columns 2 and 3).

\section{Disposition of Upland Runoff}

The proportion of surface runoff that reaches the valley as channeled flow also must be specified. In many cases, the topographic expression of the subbasins may be used to estimate this quantity (Handman, 1986). Topographic maps show that upland zones 1-3, 9, and 11-15 of the model have a few gullies notched into the side of Killbuck Creek valley, but no streams that extend out to Killbuck Creek or to major tributaries. The hillside gullies undoubtedly carry storm runoff at times, but apparently much of it infillrates near the base of the hillside rather than forming permanent channels across the valley floor. Therefore, these zones were specified as having no channeled runoff. If modeling were to be carried out on a more detailed scale, perhaps a few of the hillside gullies could be simulated individually. For zones 4-8, estimates of channeled runoff ranging upward from 50 percent were specified (table 10, column 4). These values are rough estimates and are based on the proportion of hillside area within each subbasin that slopes toward a tributary stream valley relative to the proportion that slopes toward the Killbuck Creek valley. The proportion of upland runoff that becomes unchanneled runoff is the difference between the available runoff and the channeled runoff. The unchanneled runoff is distributed as water available for recharge to nodes located within the valley, adjacent to each upland zone.The location of these nodes is shown on plate 2 , and the number of nodes, per zone, is given in table 10 , column 5. For upland zones with channeled flow, the number of explicitly simulated tributary streams emanating from each zone and the number of model nodes containing a tributary stream is also specified (table 10, columns 6 and 7).

The tributary streams designated to receive channeled runoff from the uplanils are shown in plate 2. These streams are simulated within the Variable-Recharge procedure in a manner similar to the Stream Package (Prudic, 1989), with the exception that the streamflow in the upstream node of each stream, rather than being specified as part of the model input, is calculated within the model and distributed according to information specified in table 10.

The calculated channeled surface-runoff is applied to the upstream node of each of the simulated tributary streams emanating from the uplands (pl. 2). From that point on, the disposition of the channeled surface-runoff is a function of the relation between stream-surface elevation and head in the valley nodes beneath the streams. Thus, the streams may gain or lose water as they flow across the valley floor.

For valley nodes designated to receive unchanneled surface runoff, the actual quantity of recharge entering the nodes is calculated according to equations $3 \mathrm{a}$ through $3 \mathrm{c}$. Thus, if the water level in these nodes rises to or near land surface, recharge is cut off or reduced, and a node may become a seepage node (eq. 3d). There is, however, no provision to apply rejected recharge and seepage occurring in the valley to other parts of the model. In these cases, if field evidence indicates that seepage does not in fact occur, then the hydraulic properties of the region in question can be adjusted to lower the simulated heads. If seepage does occur, presumably some channel exists to conduct it to the master stream and out of the modeled area, or the region has wetland characteristics.

\section{Hydraulic Properties of Streams and Drains}

Little Killbuck, Clear, and Apple Crecks (pl. 1) were simulated with the Stream Package (Prudic, 1989), whereas the smaller tributary streams that emanate from the active upland-segments (pl. 2) were simulated as part of the Variable-Recharge procedure. In addition, an unnamed, intermittent tributary stream whose source is spring 32, north of Silver Road (pl. 1) was simulated with the Stream Package. This feature is hereafter termed the midvalley tributary stream. Both procedurcs require specification of the quantity of flow in the upstream node of each stream, streambed conduclance, and elevations of the stream surface and of the top and bottom of the streambed. Streambed conductance 
Table 10. Variable-Recharge procedure input data specifying the distribution of recharge and runoff for upland recharge zones 1 through 15

[ $R_{\text {wa }}$ is the calculated water available for recharge, equation 2]

\begin{tabular}{|c|c|c|c|c|c|c|}
\hline 1 & 2 & 3 & 4 & 5 & 6 & 7 \\
\hline $\begin{array}{c}\text { Upland } \\
\text { zone }\end{array}$ & $\begin{array}{l}\text { Percent } \\
\text { of } \mathrm{P}_{\text {wa }} \\
\text { applled } \\
\text { to zone }\end{array}$ & $\begin{array}{l}\text { Percent of } \\
\text { upland } \\
\text { runoff } \\
\text { avallable to } \\
\text { recharge } \\
\text { valley }\end{array}$ & $\begin{array}{l}\text { Percent of } \\
\text { upland } \\
\text { runoff } \\
\text { appearing as } \\
\text { channeled } \\
\text { flow }\end{array}$ & $\begin{array}{l}\text { Number of } \\
\text { valley nodes } \\
\text { recolving } \\
\text { unchanneled } \\
\text { flow }\end{array}$ & $\begin{array}{l}\text { Number of } \\
\text { tributary } \\
\text { streamal } \\
\text { channels }\end{array}$ & $\begin{array}{c}\text { Number of } \\
\text { nodes per } \\
\text { channel }\end{array}$ \\
\hline 1 & 100 & 100 & 0 & 7 & 0 & 0 \\
\hline 2 & 100 & 100 & 0 & 11 & 0 & 0 \\
\hline 3 & 100 & 100 & 0 & 9 & 0 & 0 \\
\hline 4 & 100 & 100 & 75 & 5 & 1 & 6 \\
\hline 5 & 100 & 100 & 80 & 8 & 1 & 12 \\
\hline 6 & 100 & 100 & 87 & 9 & 1 & 11 \\
\hline 7 & 100 & 100 & 50 & 8 & 2 & 4 and 2 \\
\hline 8 & 100 & 100 & 50 & 5 & 1 & 9 \\
\hline 9 & 100 & 100 & 0 & 7 & 0 & 0 \\
\hline 10 & 50 & 50 & 0 & 21 & 0 & 0 \\
\hline 11 & 100 & 100 & 0 & 4 & 0 & 0 \\
\hline 12 & 100 & 100 & 0 & 2 & 0 & 0 \\
\hline 13 & 100 & 100 & 0 & 3 & 0 & 0 \\
\hline 14 & 100 & 100 & 0 & 5 & 0 & 0 \\
\hline 15 & 100 & 100 & 0 & 13 & 0 & 0 \\
\hline
\end{tabular}

(CRIV) for each node containing a stream is defined as

$$
C R I V=(K / m) A, \quad\left(\mathrm{~L}^{2} / \mathrm{t}\right)
$$

where $\mathrm{K}$ is the vertical hydraulic conductivity of the streambed materials, $m$ is the streambed thickness, and $\mathrm{A}$ is the area of the stream within the node.

The hydraulic interaction between layer 1 and Killbuck Creek and an extensive network of agricultural-tile drains (pl. 2) were simulated by the River and Drain Packages (McDonald and Harbaugh, 1988), respectively. The River Package requires specification of streambed conductance and elevation of the stream surface and streambed bottom. For each node containing a drain, the Drain Package requires specification of the drain elevation and a conductance term which incorporates the effect of all processes contributing to head loss between the drain and the surrounding material in which the model head prevails. The drains were assigned a uniform elevation corresponding to a depth $5 \mathrm{ft}$ below land-surface elevation. The conductance of all drains was set at $0.05 \mathrm{ft}^{2} / \mathrm{s}$. This value, although somewhat arbitrary, produced flows to the drains that appear to be reasonable and, in one locale in the drain system (FT of pl. 1), was commensurate with measured flow.

For the steady-state simulation, stream-surface elevations were derived from point measurements of stream stage at streambed piezometers, and interpolation between point measurements, or were estimated from topographic contours. Elevations of the top and bottom of streambeds were obtained by applying the estimated water depths and streambed thicknesses to the stream-surface elevation (table 11). 1n most cases, the elevations describing the physical characteristics of the streams are approximations of actual conditions. Streambed hydraulic conductances (eq. 4) were calculated by use of the streambed leakance $(\mathrm{K} / \mathrm{m})$ and width values given in table 11 , together with the dimensions of the finite-difference cells containing stream reaches. The analysis of the seepage-meter 
Table 11. Input data for the Stream and River Packages of the USGS modular ground-water-flow model and VariableRecharge procedure, steady-state simulation

$\left[\mathrm{ft}^{3} / \mathrm{s}\right.$, cubic feet per second; $\mathrm{K} / \mathrm{m}$, vertical hydraulic conductivity of streambed divided by streambed thickness; (ft/d)/ft, feet per day per foot; $\mathrm{ft}$, feet; *, initial streamflow at upstream node is calculated by the model from upland runoff occurring in the upland recharge zone containing the tributary streams; --, no measurement]

\begin{tabular}{|c|c|c|c|c|c|c|}
\hline \multirow[b]{2}{*}{ Feature } & \multirow[b]{2}{*}{$\begin{array}{c}\text { Model } \\
\text { reech } \\
\text { (row, column) }\end{array}$} & \multirow{2}{*}{$\begin{array}{l}\text { Inltial } \\
\text { stream- } \\
\text { flow } \\
\left(\mathrm{ft}^{3} / \mathrm{s}\right)\end{array}$} & \multirow{2}{*}{$\begin{array}{c}\text { Streambed } \\
\text { ieakance, } \\
\mathrm{K} / \mathrm{m} \\
{[(\mathrm{ft} / \mathrm{d}) / \mathrm{ft}]}\end{array}$} & \multicolumn{3}{|c|}{ Streambed propertles } \\
\hline & & & & $\begin{array}{l}\text { Stream } \\
\text { wldth } \\
\text { (fi) }\end{array}$ & $\begin{array}{l}\text { Top of } \\
\text { streambed } \\
\text { (ft) }\end{array}$ & $\begin{array}{l}\text { Bottom of } \\
\text { streambed } \\
\text { (ft) }\end{array}$ \\
\hline \multirow[t]{4}{*}{ Killbuck Creek } & $(1,47)-(23,36)$ & -- & 1.0 & 35.0 & -- & 5.0 \\
\hline & $(24,36)-(39,36)$ & -- & 0.1 & 35.0 & -- & 5.0 \\
\hline & $(40,36)-(45,36)$ & -- & 0.025 & 35.0 & -- & 5.0 \\
\hline & $(46,36)-(84,26)$ & -- & 0.01 & 35.0 & -- & 5.0 \\
\hline \multirow[t]{2}{*}{ Little Killbuck Creek } & $(3,18)-(11,42)$ & 5.0 & 5.0 & 20.0 & 1.0 & 2.0 \\
\hline & $(11,43)-(12,44)$ & -- & 1.0 & 20.0 & 1.0 & 2.0 \\
\hline \multirow[t]{7}{*}{ Clear Creek } & $(29,44)-(29,43)$ & 3.0 & 10.0 & 10.0 & 1.0 & 6.0 \\
\hline & $(29,42)$ & -- & 10.0 & 10.0 & 1.0 & 5.0 \\
\hline & $(29,41)$ & -- & 10.0 & 10.0 & 1.0 & 4.5 \\
\hline & $(29,40)$ & -- & 10.0 & 10.0 & 1.0 & 4.0 \\
\hline & $(30,39)$ & -- & 10.0 & 10.0 & 1.0 & 3.0 \\
\hline & $(31,38)$ & -- & 10.0 & 10.0 & 1.0 & 2.5 \\
\hline & $(31,37)$ & -- & 2.0 & 10.0 & 1.0 & 2.5 \\
\hline \multirow[t]{3}{*}{ Apple Creek } & $(76,64)-(76,60)$ & 10.0 & 0.06 & 35.0 & 4.0 & 5.0 \\
\hline & $(75,59)-(73,56)$ & -- & 0.04 & 35.0 & 4.0 & 5.0 \\
\hline & $(73,55)-(74,47)$ & -- & 0.025 & 35.0 & 4.0 & 5.0 \\
\hline \multirow{3}{*}{$\begin{array}{l}\text { Midvalley tributary } \\
\text { stream }\end{array}$} & $(12,37)-(13,36)$ & 0.0 & 0.35 & 5.0 & 1.0 & 2.0 \\
\hline & $(14,35)-(15,34)$ & -- & 0.26 & 5.0 & 1.0 & 2.0 \\
\hline & $(16,33)-(51,35)$ & -- & 0.10 & 5.0 & 1.0 & 2.0 \\
\hline $\begin{array}{l}\text { Variable-Recharge } \\
\text { tributary streams }\end{array}$ & each node & * & 0.1 & 8.0 & 1.0 & 2.0 \\
\hline
\end{tabular}

measurements and the work of Springer (1987 and 1990 ) in terms of providing quantitative estimates of streambed conductance was inconclusive. Consequently, an initial estimate of $1(\mathrm{ft} / \mathrm{d}) / \mathrm{ft}$ was used for Killbuck Creek along its entire length and adjusted on the basis of the model calibration. The relatively low values of streambed leakance used in the simulation for reaches adjacent to the north and south well fields are representative of the predominantly silly clay that underlies the Killbuck Creek streambed along these reaches. Silty clay also comprises the streambed of Apple Creek near the south well field and the midvalley tributary stream. Field evidence indicates somewhal coarser streambed materials in Killbuck Creek in the northern part of the model. For the Little Killbuck and Clear Creek streambeds, the higher values of streambed leakance (table 11) are indicative of coarse-grained alluvial-fan deposits found in these areas.

For the tributary streams simulated as part of the Variable-Recharge procedure (pl. 2), elevations of stream surfaces and top and bottom of the streambed were calculated within the model from specified depths below land-surface elevation (pl. 3). For the steady-state simulation, these were set at 3,4 , and $5 \mathrm{ft}$ below land surface, respectively. 


\section{Hydraulic Conductivity and Vertical Leakage}

Initial estimates of the hydraulic conductivity of the Killbuck Creek valley sediments were derived from a variety of sources including well logs (Jones and others, 1958; Mayhew, 1985), aquifer tests (table 12), and the interpretation of electrical-resistivity and electromagneticconductivity survey data. Analysis of the well logs indicates that the clay, silt, sand, and gravel sediments within the Killbuck Creek valley have a high degree of lateral and vertical variability. The well logs are from wells located primarily in the vicinity of the north and south well fields. Elsewhere along the margins of the valley, north of the north well field and in the region between the north and south well fields, apparent resistivity from an electrical-resistivity survey (Jones and others, 1958) and apparent conductivity from an electromagnetic survey conducted by the USGS in July 1986 were used as a guide in estimating the spatial variability of hydraulic conductivity. The 1986 electromagnetic survey was performed with a Geonics, EM-31 ${ }^{2}$ instrument (McNeill, 1980), which responds to the electrical properties of earth materials to a maximum depth of about $20 \mathrm{ft}$. The areas containing data from the EM-31 survey are shown in plate 1 . The electrical-resistivity survey lines of Jones and others (1958) were spaced about $1,000 \mathrm{ft}$ apart in the vicinity of the north well field and about $500 \mathrm{ft}$ apart to the south. Along each survey line, measurements were made at sites spaced about $250 \mathrm{ft}$ apart. At each site, resistivity data were collected with electrode spacings of 20 , $40,60,80,120$, and $160 \mathrm{ft}$, thereby obtaining a measure of apparent resistivity as a function of depth. These data display a general three-layered pattem (Jones and others, 1958) wherein the apparent resistivity, except in small areas, is relatively low for the shallow (less than 20 -ft depth) system, relatively high for intermediate (40- to 80-ft) depths, and relatively low for the deep (greater than $120-\mathrm{ft}$ ) subsurface. From these data, two contour maps were prepared representing apparent resistivity of the shallow- and intermediate-depth systems. The EM-31 data were incorporated in the shallow-source map after values

\footnotetext{
${ }^{2}$ Any use of trade names in this publication is for descriptive purposes only and does not imply endorsement by the U.S. Government.
}

of conductivity were converted to electrical resistivity.

It was assumed that the salinity of the ground water was spatially uniform, and that a qualitative correlation exists between the spatial variability of the shallow-source apparent resistivity and model layer-1 horizontal hydraulic conductivity. Likewise, a qualitative correlation was assumed between the variability of the intermediate depth apparent resistivity, which ranges from about 160 to $600 \mathrm{ohm}-\mathrm{ft}$, and horizontal hydraulic conductivities of model layers 2 and 3. Two horizontal hydraulicconductivity zone maps were then prepared in which model nodes within the valley were partitioned into a series of zones corresponding to particular ranges of shallow- and intermediatedepth apparent resistivity. Information from well logs (Jones and others, 1958, and Allan Razem, U.S. Geological Survey, written commun., 1984), was also used to design this zonation.

The zone map for layer 1 (pl. 4) was then used to generate model-input values of horizontal hydraulic conductivity by assigning a horizontal hydraulic conductivity to each zone and, thereby, to each node within a zone. The layer 1 zone map was also used to assign values of vertical leakance between layers 1 and 2 . In general, the highest vertical-leakance values correspond to zones of higher apparent resistivity. Horizontal hydraulic conductivity, similarly assigned to each zone in the intermediate-depth zone map (pl. 5), was multiplied by the thicknesses assigned to layers 2 and 3 to generate model-input values of transmissivity for those layers at each node. The intermediate-depth zone map was also used as a basis for estimating values of vertical-leak ance between layers 2 and 3 . During the calibration process, in order to improve the fit between observed and model values, adjustments and additions were made to the original zone maps. The upland zones (41-55), shown in plates 4 and 5 , are coincident with the previously discussed upland recharge-zones (pl. 2).

\section{Transient Simulation Data}

For the transient simulation, changes in stresses relative to steady-state conditions were made to reflect average conditions over the 11-day period 23 February through 5 March 1985. These con- 
Table 12. Estimates of horizontal hydraulic properties of sand and gravel deposits from aquifer test data collected in Killbuck Creek valley, Ohio

[ft ${ }^{2} / d$, feet squared per day; $f t$, feet; $f t / d a y$, feet per day; --, no measurement]

\begin{tabular}{|c|c|c|c|c|c|}
\hline Location & $\begin{array}{l}\text { Transmis- } \\
\text { sivity } \\
\left(\mathrm{ft}^{2} / \mathrm{d}\right)^{1}\end{array}$ & $\begin{array}{l}\text { Thlok- } \\
\text { ness } \\
\text { (ft) }\end{array}$ & $\begin{array}{l}\text { Horizontal hydraulic } \\
\text { conductivity } \\
\text { (ft/day) }\end{array}$ & $\begin{array}{c}\text { Storage } \\
\text { coefficient } \\
\text { (dimenslonless) }\end{array}$ & Sources \\
\hline North well field & 30,800 & 53 & 580 & 0.0015 & Jones and others (1958) \\
\hline $\begin{array}{l}\text { (Re-interpretation } \\
\text { of above } \\
\text { data) }\end{array}$ & 12,000 & 53 & 230 & 0.02 & $\begin{array}{l}\text { S. Norris, Consulting Hydro- } \\
\text { geologist, written commun., } \\
1986\end{array}$ \\
\hline Church of Savior well & 13,400 & 35 & 380 & -. & This study \\
\hline \multicolumn{6}{|l|}{ South well field } \\
\hline Well PS1 & 66,900 & 85 & 790 & 0.0043 & Jones and others (1958) \\
\hline Well PS2 & 93,600 & 86 & 1,090 & 0.00051 & Miller, L.E. (1976) \\
\hline $\begin{array}{l}\text { South of well field } \\
\text { along Prairie Lane }\end{array}$ & 26,700 & -- & $\begin{array}{r}510 \\
\text { to } 690\end{array}$ & -- & $\begin{array}{l}\text { Miller, L.M., and Associates } \\
\text { (1981) }\end{array}$ \\
\hline $\begin{array}{l}\text { North of Apple Creek } \\
\text { between test } \\
\text { wells } 17 \text { and } 20\end{array}$ & 42,800 & & $\begin{array}{r}120 \\
\text { to } 270\end{array}$ & & $\begin{array}{l}\text { G.H. Mayhew, Hydro- } \\
\text { geologist, Ohio Drilling } \\
\text { Co., written commun., } \\
1989\end{array}$ \\
\hline
\end{tabular}

\footnotetext{
${ }^{1}$ Reported values rounded to nearest $100 \mathrm{ft}^{2} / \mathrm{d}$

${ }^{2}$ Reported values rounded to nearest $10 \mathrm{ft}^{2} / \mathrm{d}$
}

sisted of a 3-ft increase in elevation of all stream surfaces for Killbuck, Little Killbuck, Clear, and Apple Creeks, and a 2-ft increase for the small tributary streams simulated with the VariableRecharge procedure. These increases are approximations of conditions observed in the field. Other transient stresses included a value of water available for recharge commensurate with the water equivalent to the 18 -in. snowmelt (table 9), elimination of pumpage from the south well field (table 8 and table 13), and application of southerly directed fluxes along the valley portion of the southern edge of the model (table 13). Pumpage from the south well field was eliminated because there was no pumping fron this area during the transient-simulation time period.

Starting with the simulated steady-state heads as the initial condition, and application of the stresses and storage properties given in table 13 , the 11-day transient simulation was implemented over three time-steps of 3-, 3.6-, and 4.4-day duration.
Because the storage-coefficient estimates that were derived from aquifer tests (table 12) display a wide variability for similar materials, the storage properties used in the transient simulation were selected from published ranges of values (Freeze and Cherry, 1979; Todd, 1970)

\section{Model Calibration}

The steady-state and transient models were calibrated to measured values of head in piezometers and, where appropriate, strcambed gain/loss estimates. Comparisons of simulated versus observed data values indicate that the data used in the simulation and the resulting flow patterns replicate conditions within the Killbuck Creek valley fairly well. The following section describes the data used in the calibration cffort and the resulting comparisons made between the modeled and actual hydrologic system. The section is concluded with a discussion of some of the limitations and validity of the model. 
Table 13. Storage properties and stresses used in the transient simulation

[ft, feet; $\mathrm{ft} / \mathrm{s}$, feel per second; $\mathrm{ft}^{3} / \mathrm{s}$, cubic feet per second]

Storage properties

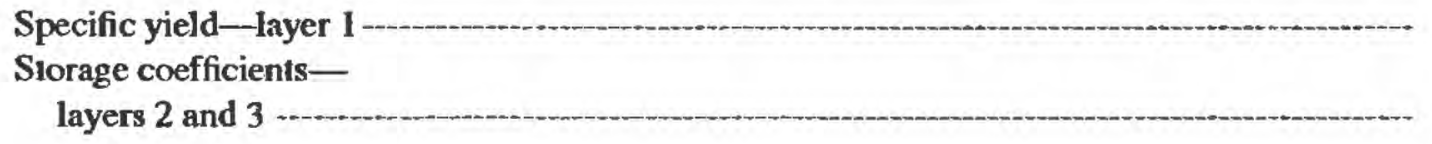

Stresses

Stream surface elevations

Rate of water available for recharge

Fluxes (per model node) applied to

valley nodes along southem boundary:

Row and column

$(84,23)$ through $(84,28)$ -

$(84,29)$

$(84,30)$ through $(84,38)$

$(84,39)$ through $(84,42)$.

$(84,43)$ through $(84,49)$

$(84,50)$

$(84,51)$ through $(84,52)$ -

Pumping

South well field

North well field
0.03

0.0003 in valley, 0.00005 in uplands $3 \mathrm{ft}$ above elevations of
fall 1984 steady-state
simulation
$2.2 \times 10^{-7} \mathrm{ft} / \mathrm{s}$

$\begin{array}{cc}\begin{array}{c}\text { Layer 2 } \\ \left(\mathrm{ft}^{3} / \mathrm{s}\right)\end{array} & \begin{array}{c}\text { Layer 3 } \\ \left(\mathrm{ft}^{3} / \mathrm{s}\right)\end{array} \\ -0.0013 & -0.00043 \\ -0.001 & -0.00035 \\ -0.021 & -0.021 \\ -0.026 & -0.026 \\ -0.034 & -0.034 \\ -0.0017 & -0.0006 \\ -0.0026 & -0.0009\end{array}$

pumping rate set to zero pumping rates are same as steady-state model (table 8)

\section{Steady-State Calibration}

The steady-state calibration process consisted of varying hydraulic properties over a plausible range of values until known characteristics of the aquifer system were approximately replicated. The final set of hydraulic properties associated with each zone for model layers 1, 2, and 3 (pls. 4 and 5) are given in tables 14 and 15 . The calibrated values of streambed leakance (ec. 4) for the simulated streams are given in table 11. For the north well field area, the model was calibrated with respect to the average of water-level measurements made during the fall of 1984 in 13 observation wells open to model layers 2 or 3 and water-level measurements in 8 streamhed piczometers open to model layer 1 (pl. 1 and table 6). For the south well field, the water-level measurements used for calibration were made on 25 November 1986 (Springer, 1987) in 24 observation wells open to model layer 2 or 3. In addition, measurements from 9 widely scattered wells in the uplands (pl. 1 and table 6) and streambed loss/gain estimates (tables 3 and 4) were available for comparison with simulated values. The head distributions for the north and south well fields within subregions containing the production wells, streambed piezometers, and observation wells used in the calibration are shown in plate 6 and figure 5 . The contours were produced by applying a one-dimensional cubic spline interpolation to the unequally spaced model-heads to create a uniform spacing of $100 \mathrm{ft}$ (Davis and Kontis, 1970) along model rows and then along model columns. Also shown is the difference in magnitude between observed values and the corresponding interpolated model-heads for layers 2 and 3. Layer-2 observation wells designaled with the word "dry" (pl. 6B) are those that werc dry during the fall of 1984. The indicated difference for these wells is the elevation of the bollom of the screened interval minus the interpolated modelhead. Thus, the simulated head for well S7 was 
A

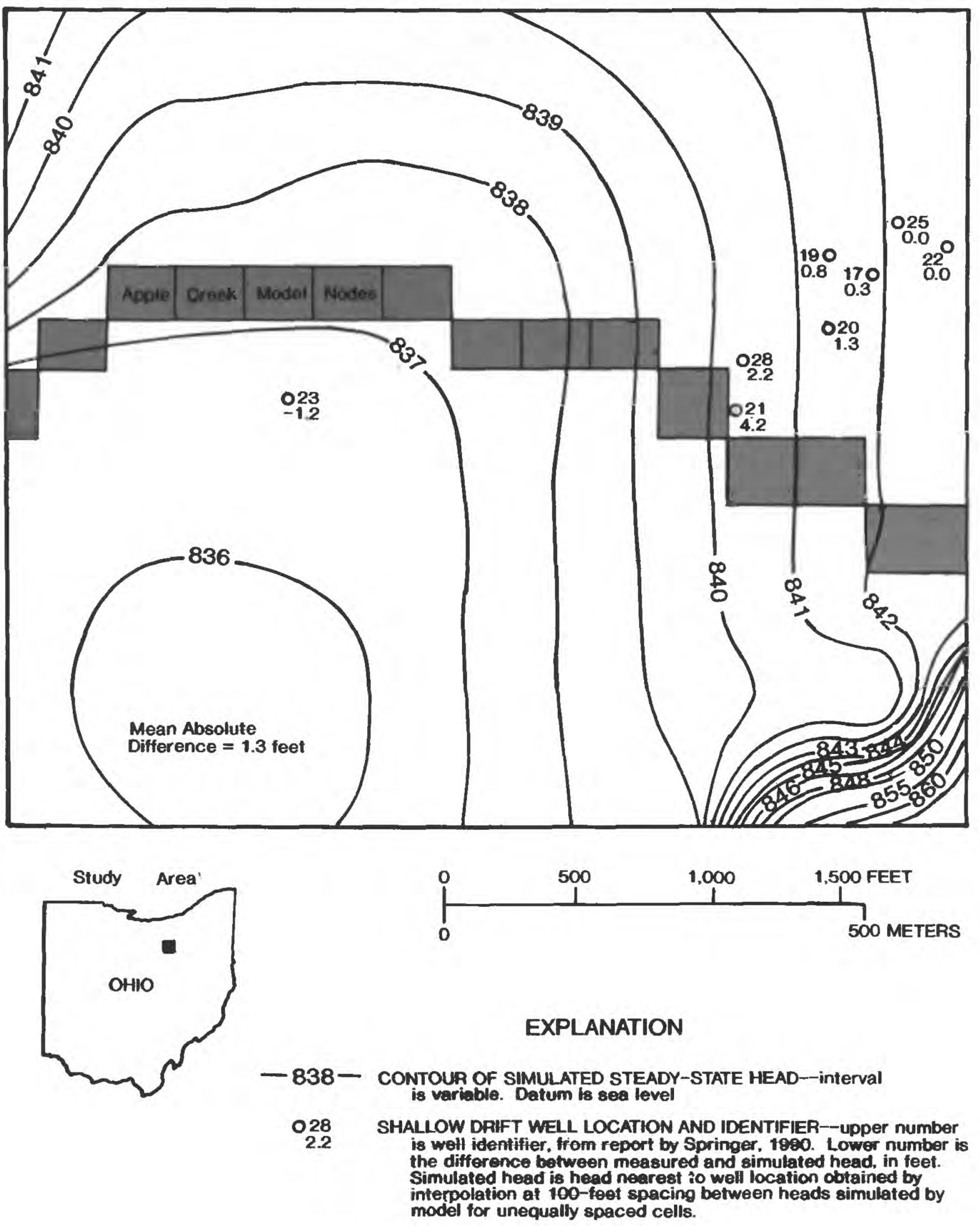

Flgure 5. Contours of simulated steady-state head in south well field subregion for (A) model layer 2, and (B) model layer. 3; and comparison with heads measured on November 25, 1986. 
B

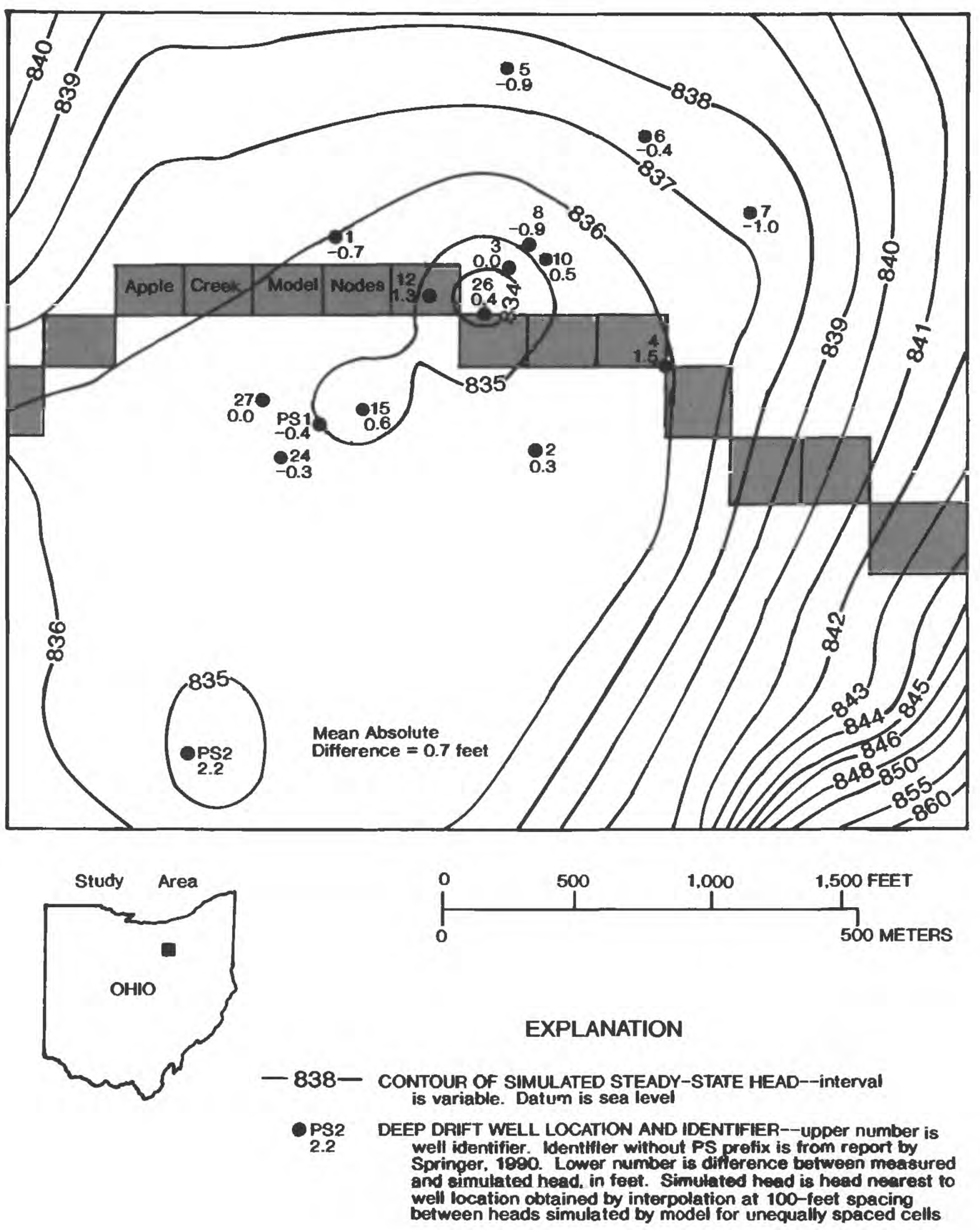

Figure 5. Contours of simulated steady-state head in south well field subregion for (A) model layer 2, and (B) model layer 3; and comparison with heads measured on November 25, 1986--Continued. 
Table 14. Zonal values of horizontal hydraulic conductivity for layer 1 and vertical leakance between layers 1 and 2

[ft/d, feet per day; (ft/s)/ft, feet per second per foot]

\begin{tabular}{|c|c|c|c|}
\hline \multicolumn{2}{|c|}{ Layer 1} & \multicolumn{2}{|c|}{ Between layers 1 and 2} \\
\hline Zone(s) & $\begin{array}{c}\text { Horlzontal } \\
\text { hydraulic } \\
\text { conductivity } \\
\text { (ft/d) }\end{array}$ & Zone(s) & $\begin{array}{l}\text { Vertical } \\
\text { leakance } \\
{[(f t / s) / f t]}\end{array}$ \\
\hline $8,11,12,18,19$ & 0.25 & 19 & $2.5 \times 10^{9}$ \\
\hline $1,10,16$ & 0.50 & 17 & $1.0 \times 10^{-8}$ \\
\hline 6 & 1.0 & $4,8,16$ & $1.25 \times 10^{-8}$ \\
\hline 4 & 3.0 & 1 & $5.0 \times 10^{-8}$ \\
\hline $2,5,14$ & 5.0 & $12,20,21$ & $1.0 \times 10^{7}$ \\
\hline 3,21 & 10.0 & 11 & $5.0 \times 10^{-7}$ \\
\hline 7 & 20.0 & 10,13 & $1.0 \times 10^{-6}$ \\
\hline 17 & 25.0 & $2,6,14,18$ & $2.0 \times 10^{-6}$ \\
\hline $13,15,20$ & 75.0 & 5 & $5.0 \times 10^{-6}$ \\
\hline \multirow[t]{2}{*}{9} & 100.0 & $3,7,15$ & $1.0 \times 10^{-5}$ \\
\hline & & 9 & $2.5 \times 10^{-4}$ \\
\hline 41 through 55 & 0.3 & 41 through 55 & $1.0 \times 10^{-9}$ \\
\hline 22 through 25 & 0.0 & 22 through 25 & 0.0 \\
\hline
\end{tabular}

Table 15. Zonal values of horizontal hydraulic conductivity for layers 2 and 3 and vertical leakance between layers 2 and 3

[ft/d, feet per day; (ft/s)/ft, feet per second per foot]

\begin{tabular}{|c|c|c|c|c|c|}
\hline \multicolumn{2}{|c|}{ Layer 2} & \multicolumn{2}{|c|}{ Between layers 2 and 3} & \multicolumn{2}{|c|}{ Layer 3} \\
\hline Zone(s) & $\begin{array}{l}\text { orlzontal } \\
\text { ydraulic } \\
\text { nductlvity } \\
\text { (ft/d) }\end{array}$ & Zone(s) & $\begin{array}{l}\text { Vertical } \\
\qquad[(\mathrm{ft} / \mathrm{s}) / \mathrm{ft}]\end{array}$ & Zone(s) & $(f t / d)$ \\
\hline 11,28 & 5.0 & 15,24 & $1.0 \times 10^{-9}$ & $11,24,28,29$ & 5.0 \\
\hline 29 & 25.0 & 10 & $5.0 \times 10^{-9}$ & 22,26 & 10.0 \\
\hline $1,12,13,19,26$ & 50.0 & 19 & $1.0 \times 10^{-8}$ & $1,13,19$ & 25.0 \\
\hline 6 & 100.0 & 8,28 & $1.25 \times 10^{-8}$ & 20 & 50.0 \\
\hline $16,20,22,25$ & 150.0 & 23 & $2.5 \times 10^{-8}$ & 6,25 & 100.0 \\
\hline $2,8,18,23,24$ & 200.0 & $1,2,6,7,9,11,13$ & $1.0 \times 10^{-7}$ & 7 & 125.0 \\
\hline 7,9 & 225.0 & $16,17,18,20,26,29$ & $1.0 \times 10^{-7}$ & 16,27 & 150.0 \\
\hline 17,27 & 250.0 & 5 & $3.125 \times 10$ & $2,12,18$ & 200.0 \\
\hline 3 & 275.0 & $3,12,14,22,25,27$ & $1.0 \times 10^{-6}$ & 23 & 225.0 \\
\hline 15 & 300.0 & 4 & $1.25 \times 10^{-6}$ & 9 & 250.0 \\
\hline 10,14 & 350.0 & 30 & $2.5 \times 10^{-6}$ & 3 & 275.0 \\
\hline 4,21 & 425.0 & 21 & $1.0 \times 10^{-5}$ & 8,17 & 300.0 \\
\hline \multirow[t]{4}{*}{5,30} & 500.0 & & & 10,15 & 350.0 \\
\hline & & & & 14 & 375.0 \\
\hline & & & & $4,5,21$ & 500.0 \\
\hline & & & & 30 & 700.0 \\
\hline 41 through 55 & 0.3 & 41 through 55 & $1.0 \times 10^{-9}$ & 41 through 55 & 0.3 \\
\hline 31 through 34 & 0.0 & 31 through 34 & 0.0 & 31 through 34 & 0.0 \\
\hline
\end{tabular}


below the screen, which means that the true difference between simulated and actual water level at $\$ 7$ might be less than the computed difference of 4.1 ft (pl. 6B). The simulated head for well S11 was above the screen bottom, so the true difference between simulated and actual head is greater than the $1.2 \mathrm{ft}$ computed.

The mean absolute difference (MAD; eq. 5) was used as the statistical measure of overall model fit; that is, for $\mathrm{N}$ observation wells

$$
M A D=\frac{1}{N} \Sigma_{n=1}^{N}\left|h_{m}-h_{o}\right|_{n},
$$

where $h_{m}$ is the model head within the node associated with an observation well with water level $h_{0}$. MAD for the observation wells near the north well field was 1.4 and $1.6 \mathrm{ft}$ for layers 2 and 3 , respectively; for the south well field, the MAD was 1.3 and $0.7 \mathrm{ft}$ for layers 2 and 3 , respectively. Overall, the MAD for both layers 2 and 3 was $1.1 \mathrm{ft}$.

The steady-state layer- 1 water-table configuration in the north-well-field subregion and its relation to simulated streams is shown in plate 6 . Also given is the location of the streambed piezometers within the subregion, and a comparison between simulated values and piezometer measurements made on 27 and 28 August 1985 (table 6). In the north well field, water levels measured in late August 1985 were similar to the average of water levels measured during the fall of 1984 (figs. 3 and 4). Consequently, it was assumed that the streambed-piezometer water levels measured in August 1985 were similar to fall 1984 average levels, and therefore could be used for the steady-state calibration. For the four piezometers that were not dry (pl. 6A), the MAD is about $0.4 \mathrm{ft}$. For the three dry piezometers, the simulated head was lower than the screen-bottom elevation.

Piezometer K10, located south of the subregion, was dry in late August 1985. The simulated water level for the node containing $\mathrm{K} 10$ was considerably higher than the screen-bottom elevation.

The comparison between observed and model heads for wells located in the uplands is given in table 16. Differences between model and observed heads range from less than $1 \mathrm{ft}$ to about $32 \mathrm{ft}$, with a MAD of about $11 \mathrm{ft}$. A comparison of the simulated steady-state stream losses and gains relative to measured values is given in the subsequent section "Sources of Water in the Killbuck Creek Valley."

\section{Simulated Steady-State Head Distrlbution and Flowpaths}

The distribution of steady-state head for layer 3 only, over the entire model, is shown in plate 7. The head contours are based on values from a uniformly spaced grid of $300 \mathrm{ft}$. These values were generated from the unequally spaced model heads by applying the aforementioned one-dimensional cubic spline interpolation procedure. The gross characteristics of layer 1 and 2 heads are similar to those of layer 3. Flow in the uplands is directed toward topographic depressions and, generally, toward Killbuck Creek valley. In the northern part of the valley, in the vicinity of Little Killbuck Creek, flow is toward Killbuck Creek.In the northwell-field subregion, flow is toward the production wells from adjacent areas. In and around the south well field, flow is toward the pumping wells. A ground-water divide, located about 5,000 ft south of the north well field, separates the north and south well-field flow systems.

In the uplands, vertical flow is generally downward in the topographically high (recharge) areas and upward in topographically low(discharge) areas. In the upland discharge areas, the simulated hydraulic heads in the confined layers (layers 2 and 3) range from less than a foot to several tens of feet above land surface. Although there is little information on the actual head distribution, the simulated head in these areas may be too high. In general, upland heads in discharge areas could be readily reduced by increasing horizontal hydraulic conductivity and (or) the vertical leakance between model layers throughout the uplands or locally in discharge areas. As shown by model sensitivity analysis, upland flow patterns, the upland recharge contribution to the valley fill, and the valley head distribution can be affected by variations in upland hydraulic properties. The magnitude of the variation required to cause a lowering of head in upland discharge areas would not, however, materially alter the general characteristics of the simulated valley-fill flow system presented herein. 
Table 16. Comparison of water levels in wells in uplands measured in the fall of 1984 with heads in the uplands from steady-state simulation

[MM-DD-YY, month, day, year; ft, feet; MAD, mean absolute difference, as defined in text by equation 5]

\begin{tabular}{|c|c|c|c|c|c|c|}
\hline Well in uplands' & $\begin{array}{l}\text { Date of } \\
\text { measurement } \\
\text { (MM-DD-YY) }\end{array}$ & $\begin{array}{l}\text { Model node } \\
\text { (row, column) }\end{array}$ & Layer & $\begin{array}{l}\text { Observed } \\
\text { (ft) }\end{array}$ & Simulated & $\begin{array}{l}\text { Absolute } \\
\text { difference } \\
\text { (ft) }\end{array}$ \\
\hline$\overline{3^{3}}$ & $12-20-84$ & $(83,61)$ & 1 & $1,027.0$ & $1,005.7$ & 21.3 \\
\hline Golf Course $^{4}$ & $11-02-86$ & $(28,65)$ & 3 & $1,004.0^{5}$ & $1,033.3$ & 29.3 \\
\hline Pig Farm ${ }^{4}$ & $11-25-86$ & $(7,23)$ & 3 & 874.9 & 874.1 & 0.8 \\
\hline 15 & $11-29-84$ & $(41,19)$ & 3 & 884.0 & 883.3 & 0.7 \\
\hline 16 & $11-29-84$ & $(17,14)$ & 3 & 989.0 & $1,020.6$ & 31.6 \\
\hline 18 & $09-23-85$ & $(28,21)$ & 3 & 855.8 & 856.0 & 0.2 \\
\hline 19 (Gowins) & $11-25-86$ & $(14,25)$ & 3 & 853.3 & 859.7 & 6.4 \\
\hline 20 & $11-29-84$ & $(21,15)$ & 3 & 981.0 & 980.1 & 0.9 \\
\hline 21 (Munson) & $11-25-86$ & $(34,19)$ & 3 & 867.6 & 873.8 & 6.1 \\
\hline & & & & & \multicolumn{2}{|c|}{$M A D=10.78$} \\
\hline
\end{tabular}

\footnotetext{
${ }^{1}$ Location of well shown in plate 1.

${ }^{2}$ Simulated value is head in model cell that contains the well, except as noted.

${ }^{3}$ Well is outside of active model area; comparison is for a nearby cell $(83,61)$ in uplands with similar topographic expression. Cell is denoted as 3(MS), for model shift, on plate 1.

${ }^{4}$ From Springer, 1987.

${ }^{5}$ Observed value is average of measurements at two wells.
}

\section{Transient Calibration}

The model fit of the transient simulation, in terms of heads on 5 March 1985 and the change in heads relative to fall 1984 average conditions, is summarized in table 17 under the model 1 entries. The MAD statistics for the agreement between simulated heads and heads measured on 5 March 1985 (column 9, table 17) and between simulated and measured head changes (column 8 , table 17 ) is 1.8 and $2.5 \mathrm{ft}$, respectively. The model fit for individual wells is reasonably good except for observation well S13 (table 17). Among the various alternatives as to why the transient simulation fit poorly in the vicinity of well $S 13$, is an excessive amount of recharge from simulated upland runoff. Consequently, the transient simulation was repeated with a slightly redesigned model (model 2 ) in which 5 additional nodes, distant from $S 13$, were designated to receive unchanneled runoff from zone 6 (pl. 2), and the percentage of total available upland runoff from zone 6 to be treated as unchanneled flow (table 10) was reduced from 13 percent to 3 percent. The effect of these changes was to greatly reduce the total recharge from unchanneled runoff near well S13 and, in turn, to lower head in this vicinity. The model-heads and head-changes, relative to initial conditions, for this second case (model 2, table 17) indicate that the adjusted allocation of upland runoff resulted in a considerable improvement near well $\mathrm{S} 13$ and a reasonably good fit elsewhere. To the extent that the simulated storage properties and stresses (table 13) are approximated, the results of the transicnt simulation provide additional evidence that the general characteristics of the steady-stale simulation may be representative of aclual conditions.

\section{Validity of the Ground-Water-Flow Model}

It is to be noted that there are large segments of the ground-water-flow model in which thcre is little or no data. Where data is available, it is evident that the valley-fill materials are highly heterogeneous so that there is no reason to expect that this is not the case elsewhere. Thus, the assigned uniform hydraulic properties in the uplands and in valley 


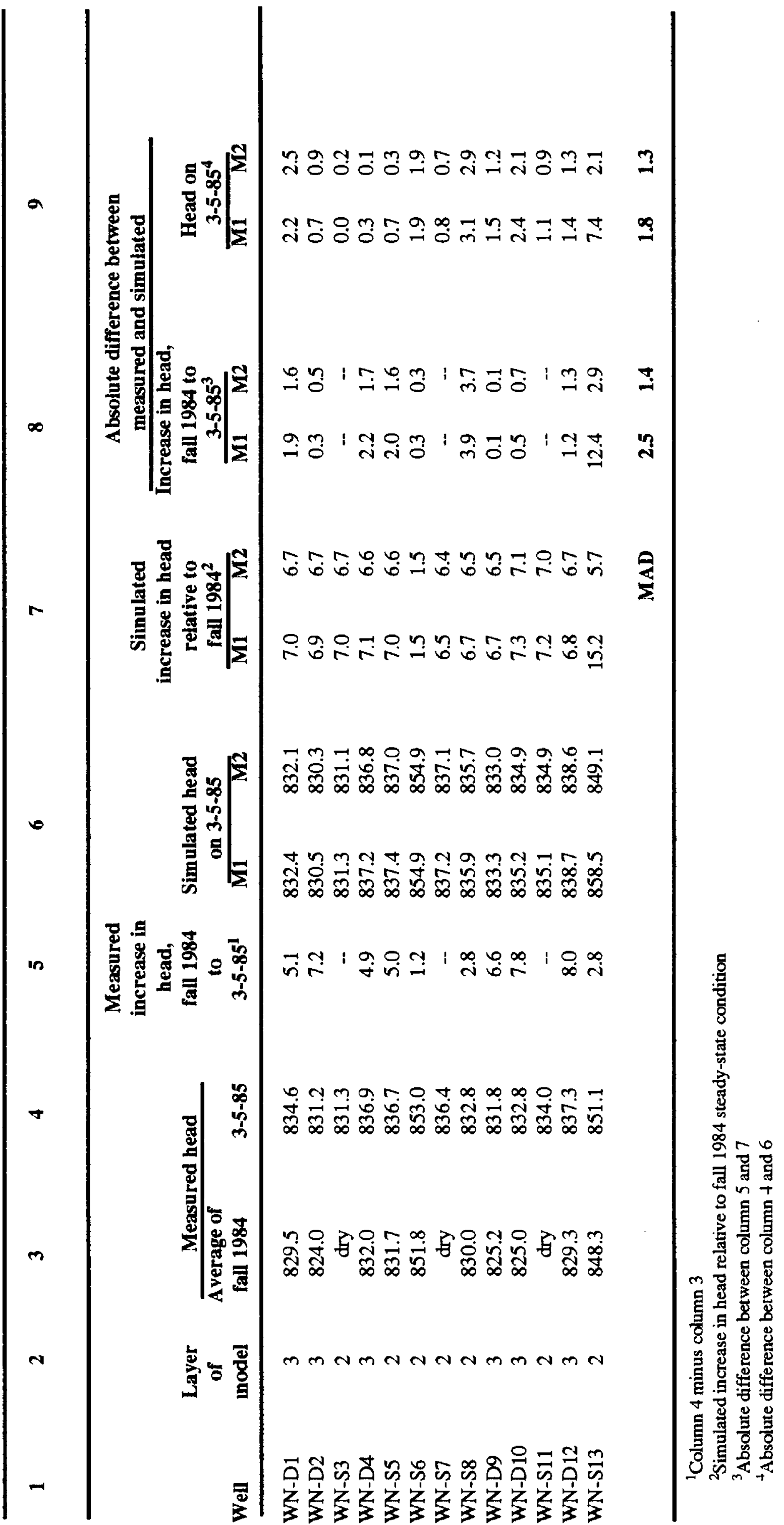


areas where data are lacking is undoubtedly a gross simplification of actual conditions. The particular combination of model geometry (fig. 2), boundary fluxes (table 8), water available for recharge (table 9), assumed criteria for the VariableRecharge procedure (table 10), hydraulic properties of streams (table 11), and hydraulic conductivities and vertical leakance for valley fill and upland materials (tables 13,14, and 15) that constitute the calibrated model, produced a head and flow distribution within the valley that matched known information reasonably well. Although this combination is a feasible representation of the hydrogeology, it is not unique. Consequently, the following discussion of sources of water that is based on model results should be considered as a possible, but by no means definitive, representation of flows for fall 1984 steady-state conditions.

\section{SOURCES OF WATER IN THE KILLBUCK CREEK VALLEY}

As previously discussed, the actual or potential sources of water to stratified-drift aquifers are direct recharge from precipitation on the valley floor, lateral flow through bedrock, upland runoff that includes lateral flow through bedrock and surface or shallow subsurface unchanneled runoff, and infiltration of streamwater from upland tributaries as well as from Killbuck Creek. Several methods of quantifying these sources are described in the following sections, and the results of model simulation of the various sources are summarized in the form of a ground-water budget.

\section{Infiltration of Streamwater}

Borehole logs, supported by geophysical data, indicate that the upper $20 \mathrm{ft}$ of unconsolidated sediment beneath Killbuck Creek valley is generally a slightly sandy, silty clay, which probably interfingers with and grades into alluvial sand and gravel only where tributaries enter the valley. The artificial channel of Killbuck Creek is incised less than $20 \mathrm{ft}$, and core sampling along the channel near the Wooster north well field indicates that channel-bar gravels are underlain by clay-rich sediments. Thus, geologic information indicates that induced infiltration of water from Killbuck Creek near the north well field should be relatively small. Heads in piezometers finished several feet below the top of the streambed were consistently below stream stage in the reach from KB3 $(2,000 \mathrm{ft}$ south of Silver Road) to Lincoln Way West, which indicates that this reach is generally losing rather than gaining. As described in the following sections, however, measurements of the rate of loss from this reach have been imprecise or inconsistent.

Streamflow measurements on 14 August 1986 (table 3), indicated a net loss of $0.7 \mathrm{ft}^{3} / \mathrm{s}$ (1) percent of flow); the ground-water-flow model approximately replicated this loss. Significant fluctuations in temperature and content of deuterium and oxygen-18 isotopes in streambed piezometers also indicates that downward seepage must be occurring; computations based on rates of change of these isotopes indicate a loss on the order of $0.03 \mathrm{ft}^{3} / \mathrm{s}$. Comparison of isotope and chloride content of water in production wells, observation wells, and streams indicates that streamwater infiltrating to the shallow-drift aquifer does not appear as streamwater in the production wells days or weeks after infiltration. Instead, the isotopic and chemical data indicate that the stream water must be diluted and mixed with ground water and dispersed within the drift such that it is chemically and isotopically unrecognizable as streamwater at the production wells. The time estimated for infiltrating streamwater to reach the shallow ground-water system beneath the stream is likely 2 montlis or more. Streamflow measurements and seepagemeter studies indicate significant instantaneous losses from Little Killbuck and Clear Creeks where they enter Killbuck Creek valley, a patten widely observed throughout the Appalachian Plateau (Morrisey and others, 1988). Losses of water from tributary streams, whether close to (Clear Creek) or distant from (Little Killbuck Creek) the production wells, were not discernible as streanwater in the production wells.

The temporal response of the aquifer to the flooding in late February 1985 was dynamic, and physical conditions in the aquifer, such as significant rises in water levels over periods of days in shallow and deep wells, indicated significant recharge to the aquifer. Streamwater, chemically 
dilute from the melted snow, with extremely light and anomalous isotopic composition, was untraceable in samples of ground water in any of the drift wells. These observalions give credence to the idea that losses from streams become blended into the larger reservoir of water in the drift aquifer. Even if the water is isotopically unique when it leaves the stream, it becomes non-unique and part of a long-term average composition of ground water in the aquifer that supplies the production wells.

\section{Results of Seepage Studies}

Measurements of streambed properties and stream gain/loss characteristics were designed to quantify stream/aquifer interactions on tributary streams and along Killbuck Creek in the vicinity of the north well field.

\section{Tributary Streams}

Measurements of streamflow at several sites on Little Killbuck Creek and Clear Creek (pl. 1) during periods of low flow in 1985 and 1986 are reported in table 4. Each reported value is the mean of two successive measurements at the same site. Both data sets show significant and consistent losses of greater than $1.8 \mathrm{ft}^{3} / \mathrm{s}$ and greater than $0.5 \mathrm{ft}^{3} / \mathrm{s}$ for Little Killbuck Creek and Clear Creek, respectively.

The losses from Little Killbuck Creek occur chicfly in a 2,000-ft reach immediately upstream from Killbuck Creek valley. The alluvium consists of coarse gravel exposed in streambank cuts. The lower end of this reach flows over alluvial-fan deposits or flood-plain alluvium that are apparent on aerial photographs. Kame-terrace deposits are mapped on the north wall of the Little Killbuck Creek valley along this reach (White, 1967) and may underlie the alluvium. Surface geophysical surveys indicate that a tongue of coarse sediment (surface conductivity of less than 10 millimhos per meter) from the Little Killbuck Creek alluvium is possibly connected to the spring discharge at site WN-32. Discharge from this spring may include a large fraction of the seepage losses from Little Killbuck Creek. The capture zone of the spring, which might include a reach of Little Killbuck Creek, was not quantified due to a lack of water-level data at points west and north of the spring. Thus, the hydraulic connection between the alluvial-fan deposits of Little Killbuck Creek and the spring can only be inferred from the surfacegeophysical data. Seepage-meter measurements in the losing reach indicate streambed vertical hydraulic conductivities of about $1 \mathrm{ft} / \mathrm{d}$ (Springer, 1990, p. 36).

The losses from Clear Creek (table 4) occur along a reach that also contains coarse fan deposits at the edge of Killbuck Creek valley and is bordered on one side by kame terrace deposits (White, 1967). Seepage-meter measurements confirm the reach is losing water and indicate that the mean streambed vertical hydraulic conductivity is about $7 \mathrm{ft} / \mathrm{d}$ (Springer, 1990, p. 36). A streambed piezometer at site $\mathrm{C} 1$ (pl. 1) was consistently dry and indicates the potential for flow from the stream to the shallow drift at a rate dependent on the vertical hydraulic conductivity of the streambed.

\section{Killbuck Creek}

Measurements of stream flow at several sites on Killbuck Creek on the same days of measurements on tributary streams are reported in table 3 . Stage remained constant during the measurements, and pumping at the north well field was kept at a constant rate of about $4.4 \mathrm{Mgal} / \mathrm{d}$.

The gain/loss studies on Killbuck Creek proved to be difficult to interpret and quantify. Apparently, the stream has both gaining and losing reaches. Piezometers driven into the streambed show a weak upward gradient at the northernmost pair near KB1 (K2/K9, table 5), intermittent upward and downward gradients at pair $\mathrm{K} 5 / \mathrm{K} 6$, and a downward gradient at pair K3/K4. There is evidence of a gaining reach (reach 1 , table 3 ) between KB1 and KB3. Seepage-meter results for the two sites between Silver Road and piezometer pair K3/K4 near KB3 were, however, inconclusive. Both gaining and losing characteristics were indicated by the scepage meter, with computed vertical hydraulic conductivities in the range of 5 to $10 \mathrm{ft} / \mathrm{d}$.

Strong downward gradients from the streambed to the shallow drift are characteristic of the system closer to the pumping stress at the north well field (tabie 5). The piezometers nearest to the well field (K1 and K8) are dry at depths of 6 and $10 \mathrm{ft}$ below stream grade. The reach of Killbuck Creek that flows past the north well field (between 
measurement section KB3 and KB6), where gradients between the stream and shallow drift are downward, was likely losing about $0.7 \mathrm{ft}^{3} / \mathrm{s}$ when measured in 1986 during a period of low flow. A loss in this reach also was indicated by the less precise 1985 measurements.

Sediment cores from the streambed below the confluence of Clear Creek and Killbuck Creek were composed of coarse gravel about one- to two-ft thick underlain by impermeable clay. The occurrence of clay probably limits stream leakage and offers an explanation for the relatively small losses of water from Killbuck Creek adjacent to the north well field.

In summary, strean)flow measurements in Killbuck Creek did not yield conclusive quantitative estimates of the gain/loss characteristics and, thus, do not give a clear understanding of stream/aquifer interactions. Several factors contributed to this situation: (1) the pools and riffles in the studied reach offer only fair to good measurement sections compared to the excellent sections generally found in the tributary streams, (2) low-flow discharges in Killbuck Creek approach magnitudes suitable for quantitative gain/ loss analysis in the 1986 data set only (streamflows in the 1985 data set are 75 percent higher than in 1986), and (3) for the 1985 data, measurements were not significantly rigorous, numerous, or consistent to define with statistical precision the gains or losses in reaches studied near the north well field.

\section{Results of Chemical and Isotopic Studies}

The chemical and isotopic studies were designed to supplement the seepage studies by providing an alternative method for quantifying stream/aquifer interactions. Studies were of two general types as follows (1) small scale, in which water characteristics in Killbuck Creek were compared with water from piezometers completed in the drift aquifer beneath the streambed, and (2) aquifer scale, in which chemical and isotopic characteristics areally and seasonally in the aquifer systems were compared with Killbuck Creek and a tributary stream (Clear Creek)

\section{Water In and Beneath Killbuck Creek}

Samples of water in Killbuck Creek and in sand and gravel beneath the stream were collecled in July and August 1985 at piezometers K2/K9, K3/K4, $\mathrm{K} 5 / \mathrm{K} 6$, and $\mathrm{K} 7$ (pl. 1). Chemical and isolopic characteristics at these sites are shown in table 18 . Complete tabulations of water-quality data collected during these two months are given in table 19 (in the supplemental data section in back of this report). Isotopic data for July 1985 indicate that water beneath the stream is isotopically lighter than water in Killbuck Creek. Waters from streambed piezometers fall on a mixing line between streamwater and representative drift water (fig. 6). The isotopic composition of representative drift water was estimated in two ways. First, the composition was assumed to be equivalent to the median isotopic composition of ground water collected from well D6. This well is completed in a deep part of the stratified-drift aquifer located upgradient of the piezometer sites and has a relatively constant isotopic composition (table 19). Second, the composition was assumed to be equivalent to the mean isotopic composition of water for deep wells in drift from September 1984 through August 1985 computed by Dysart (1988, fig. 11, p. 148). The two estimates yield nearly the same isotopic compositions. According to the isotopic data for the July samples, the waters from the streambed piezometers are composed of approximately equal proportions of stream and drift water (fig. 6A).

In contrast, waters collected from the slreambed piezometers in late August are isotopically heavier than Killbuck Creek streamwater and, therefore, cannot have been derived from mixing of August 27 streamwater and representative drift water (fig. 6b). The streambed-piezometer waters also cannot have been derived from a mixture of drift watcr and bedrock water as all ground-water samples collected during this study were isotopically lighter than the August piezometer waters (Dysar, 1988). Isotopically heavy ground water heneath Killbuck Creek in late August must have been derived from infiltration of isotopically enriched streamwater. 
Table 18. Selected chemical and isotopic characteristics of streamwaters and of shallow ground water from streambed piezometers in Killbuck Creek

$[\mu \mathrm{S} / \mathrm{cm}$, microsiemens per centimeter at 25 degrees Celsius; deg. $\mathrm{C}$, degrees Celsius; $\mathrm{mg} / \mathrm{L}$, milligrams per liter, mv, millivolts; Wayne County prefix, WN-, omitted from well number, (S), shallow piezometer of doublet; (D), deep piezometer of doublet; alkalinity values for unfiltered samples; dashes indicate constituent not determined]

\begin{tabular}{|c|c|c|c|c|c|c|c|c|c|}
\hline $\begin{array}{c}\text { Site } \\
\text { Identifier }\end{array}$ & Tlme & $\begin{array}{c}\text { Speclfic } \\
\text { conduct- } \\
\text { ance } \\
(\mu \mathrm{S} / \mathrm{cm})\end{array}$ & $\begin{array}{c}\text { pH } \\
\text { (standard } \\
\text { units) }\end{array}$ & $\begin{array}{l}\text { Temper- } \\
\text { ature, } \\
\text { water } \\
\text { (deg. C) }\end{array}$ & $\begin{array}{c}\text { Oxygen, } \\
\text { dlseolved } \\
\text { (mg/L) }\end{array}$ & $\begin{array}{c}\text { Alkallnity, } \\
\text { tolal } \\
\text { field } \\
(\mathrm{mg} / \mathrm{L} \text { as } \\
\left.\mathrm{CaCO}_{3}\right)\end{array}$ & $\begin{array}{l}\text { OxIda- } \\
\text { ton } \\
\text { reduc- } \\
\text { tion } \\
\text { poten- } \\
\text { tial } \\
\text { (mv) }\end{array}$ & $\begin{array}{l}\delta D \\
\text { per } \\
\text { mll }\end{array}$ & $\begin{array}{l}8^{18} \mathrm{O} \\
\text { per } \\
\mathrm{mil}\end{array}$ \\
\hline & & & & $\begin{array}{l}\text { K2 AND K9 } \\
\text { July } 16,1985\end{array}$ & & & & & \\
\hline Killbuck Cr. & 1115 & 630 & 8.0 & 21.5 & 7.4 & 180 & 320 & $-45.5^{1}$ & $-6.75^{1}$ \\
\hline $\mathrm{K} 2(\mathrm{~S})$ & 1230 & 610 & 7.3 & 17.5 & 0.2 & 230 & 140 & -52.0 & -8.05 \\
\hline \multirow[t]{2}{*}{ K9 (D) } & 1220 & 630 & 7.4 & 14.0 & 0.2 & 210 & 130 & -- & -- \\
\hline & & & & $\begin{array}{l}\text { K3 AND K4 } \\
\text { July 17, } 1985\end{array}$ & & & & & \\
\hline Killbuck Cr. & 1115 & 630 & 8.0 & 21.5 & 7.4 & 180 & 320 & $-45.5^{1}$ & $-6.75^{1}$ \\
\hline $\mathrm{K} 3(\mathrm{~S})$ & 1315 & 650 & 7.3 & 20.5 & 0.2 & -- & 180 & -51.0 & -7.50 \\
\hline \multirow[t]{2}{*}{$\mathrm{K} 4$ (D) } & 1250 & 617 & 7.3 & 16.5 & 0.4 & 177 & 240 & -50.0 & -7.70 \\
\hline & & & & August 27, 1985 & & & & & \\
\hline \multirow[t]{3}{*}{ Killbuck Cr. } & 0945 & 623 & 7.9 & 19.5 & 7.4 & 186 & 310 & $-43.5^{2}$ & $-7.15^{2}$ \\
\hline & 1100 & 613 & 8.0 & 20.0 & 9.6 & -- & 290 & $-\cdot$ & -- \\
\hline & 1630 & 598 & 8.0 & 22.0 & 9.5 & -- & 350 & -- & -- \\
\hline \multirow[t]{2}{*}{ K3 (S) } & 1120 & 584 & 7.2 & 21.0 & 0.2 & 170 & 240 & -41.5 & -6.65 \\
\hline & 1645 & 576 & 7.2 & 21.0 & 0.2 & -- & 180 & -- & -- \\
\hline \multirow[t]{3}{*}{ K4 (D) } & 1155 & 618 & 7.1 & 19.5 & 0.2 & 180 & 240 & -42.0 & -6.60 \\
\hline & 1700 & 609 & 7.2 & 20.0 & 0.2 & $-\cdot$ & 150 & -- & -- \\
\hline & & & & $\begin{array}{l}\text { K5 AND K6 } \\
\text { July 17, } 1985\end{array}$ & & & & & \\
\hline Killbuck Cr. & 1115 & 630 & 8.0 & 21.5 & 7.4 & 180 & 320 & $-45.5^{1}$ & $-6.75^{1}$ \\
\hline \multirow[t]{2}{*}{ K5 (D) } & 1140 & 613 & 7.1 & 18.0 & 0.4 & -- & 280 & -52.0 & -7.75 \\
\hline & & & & August 27, 1985 & & & & & \\
\hline \multirow[t]{3}{*}{ Killbuck Cr. } & 0945 & 623 & 7.9 & 19.5 & 7.4 & 186 & 310 & $-43.5^{2}$ & $-7.15^{2}$ \\
\hline & 1230 & $60) 2$ & 7.9 & 21.0 & 9.3 & $\cdots$ & 330 & -- & -- \\
\hline & 1715 & 598 & 8.0 & 22.0 & 9.2 & -- & 340 & -- & -- \\
\hline \multirow[t]{2}{*}{ K5 (D) } & 1305 & 601 & 7.0 & 18.5 & 0.2 & 178 & 210 & -41.5 & -6.75 \\
\hline & 1735 & 595 & 7.1 & 18.5 & 0.3 & -- & 240 & -- & -- \\
\hline \multirow[t]{3}{*}{ K6 (S) } & 1335 & 585 & 7.0 & 20.5 & 0.2 & 172 & 250 & -42.0 & -6.75 \\
\hline & 1800 & 580 & 7.1 & 20.0 & 0.4 & $\cdots$ & 260 & -- & -- \\
\hline & & & & $\begin{array}{c}\text { K7 } \\
\text { July } 17,1985\end{array}$ & & & & & \\
\hline Killbuck $\mathrm{Cr}_{\mathrm{r}}$ & 1115 & 630 & 8.0 & 21.5 & 7.4 & 180 & 320 & -- & - \\
\hline \multirow[t]{2}{*}{$\mathrm{K} 7$} & 1040 & 555 & 7.1 & 19.0 & 0.3 & -- & 280 & -- & - \\
\hline & & & & August 27, 1985 & & & & & \\
\hline \multirow[t]{3}{*}{ Killbuck Cr. } & 0945 & 623 & 7.9 & 19.5 & 7.4 & 186 & 310 & -- & -- \\
\hline & 1405 & 594 & 8.1 & 22.5 & 9.4 & -- & 310 & -- & - \\
\hline & 1815 & 600 & 8.0 & 22.0 & 9.2 & -- & 310 & -- & -- \\
\hline \multirow[t]{2}{*}{ K7 } & 143.5 & 583 & 6.9 & 19.5 & 0.3 & 168 & 300 & -- & -- \\
\hline & 1830 & 579 & 6.9 & 19.5 & 0.5 & -- & 330 & $\cdots$ & -- \\
\hline
\end{tabular}

'Isotopic composition in Killbuck Creek at Old Mansfield Road, time 0745.

${ }^{2}$ Mean isotopic composition from samples collected at Silver Rd, and Old Mansfield Rd. 
A

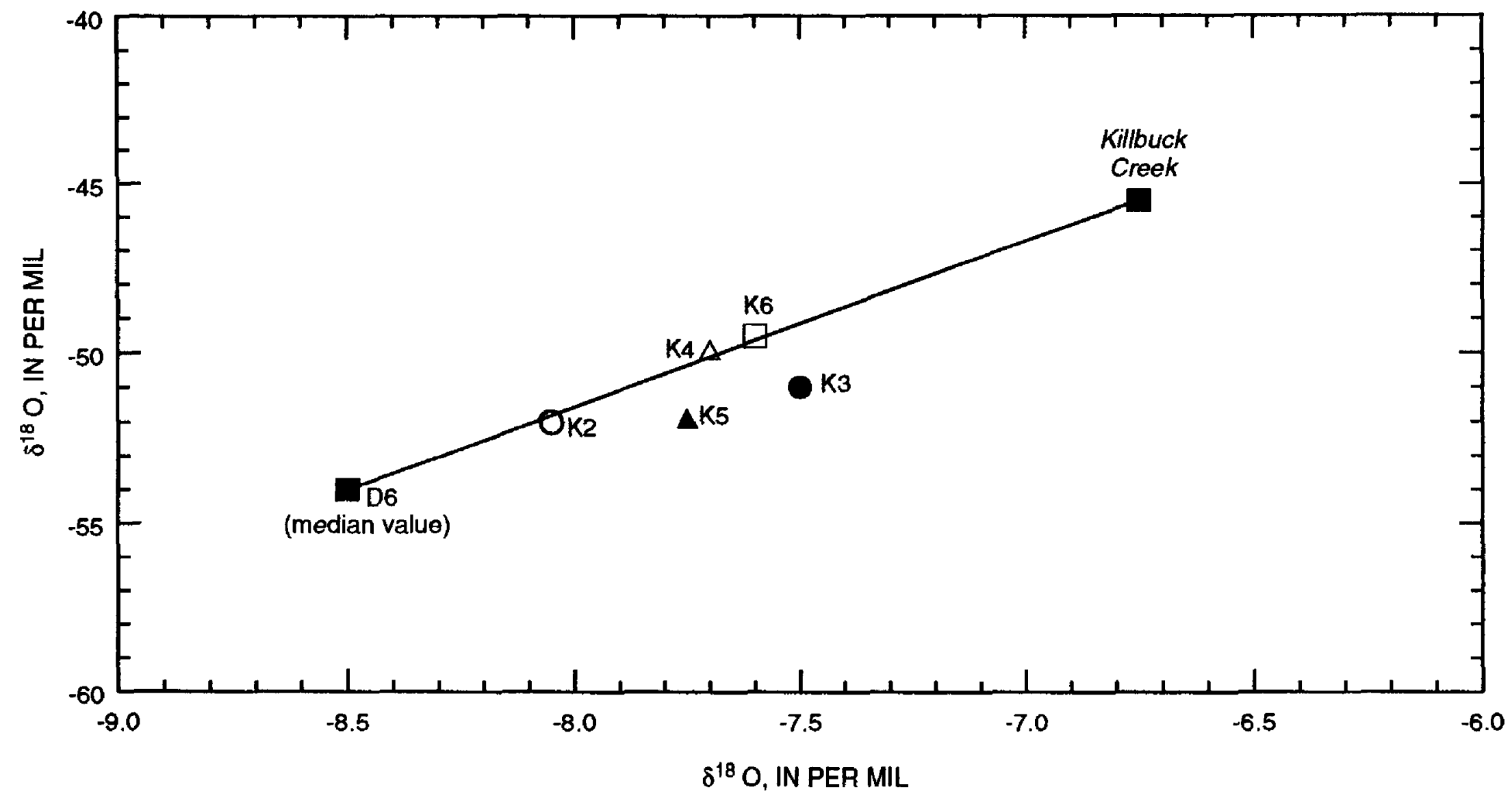

B

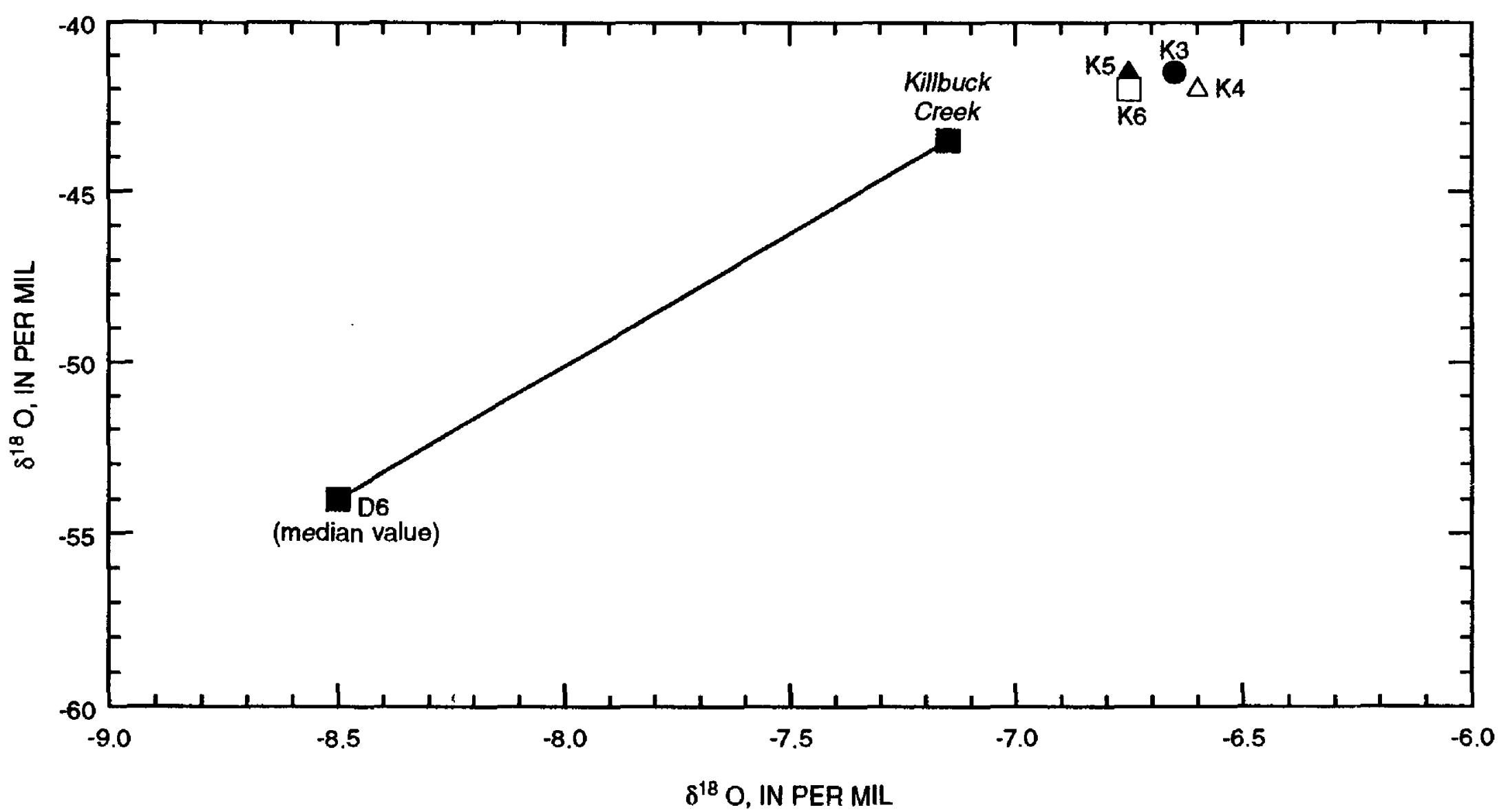

Figure 6. Mixing relations between surface and ground water beneath Killbuck Creek; based on a mixing line using two estimates of representative isotope composition for ground water and measured composition of Killbuck Creek stream water collected on (A) July 17 and (B) August 27,1985. (Wayne county prefix, WN-, omitted.) 
If the same mixing ratio betwcen stream and drift water estimated from July samples (approximately 1:1, fig. 6a) is also applicable to the piezometer waters collected in August, then the estimated isotopic composition of the streamwater would be near $\delta \mathrm{D}=-30$ per mil and $\delta^{18} \mathrm{O}=-4.5$ per mil. Waters this isotopically enriched were not found in either Killbuck Creek or its tributaries during this study although a seasonal trend towards heavier isotopic compositions in surface waters during the summer months is noted by Dysart (1988). Surface waters with isotopic compositions similar to the postulated end-member streanwater estimated above have been recorded at USGS National Stream Quality Accounting Nelwork surface-water stations in northen Ohio (Tyler Coplen, U.S. Geological Survey, written commun., 1992).

The significant change in the isotopic composition of shallow ground water between July and August indicates that a dynamic, shallow ground-water-flow system exists beneath Killbuck Creek. Vertical head gradients between the stream and shallow aquifer are larger in August than in July (table 5). Thus, as gradients increase, the amount of streamwater infiltration beneath Killbuck Creek will also increase, shifting the isotopic signature of shallow ground water beneath Killbuck Creek towards the isotopic signature of infiltrating streamwater. The differences in isotopic composition between the stream and ground water for the measured dates indicate that movement of water from the stream to the shallow aquifer is not as fast as indicated by the seepage-meter leakage rates ( 5 to $10 \mathrm{ft} / \mathrm{d}$ ). The "heavier" isotopic signature of shallow ground water in August compared to July indicates that leakage rates may be as slow as 5 to $10 \mathrm{ft}$ per month. This is the approximate distance between the streambed and the piezometer screen that was covered between samples. Assuming a distance of $7.5 \mathrm{ft}$ between the streambed and the piezometer screen and by use of the time of 1.3 months between the July 17 and August 27 samples, an areally integrated estimate of the minimum stream leakage rate was calculated. The calculation for the 3,000-ft reach of Killbuck Creek from KB3 to Lincoln Way West is as follows at the top of the next page. More frequent sampling at regular intervals would be required to further define and constrain this semiquantitative result for a rate of stream leakage.

Well S8, located $50 \mathrm{ft}$ east of Killbuck Creek and downgradient of the losing reach of Clear Creek, was hypothesized to be the well most likely to demonstrate the effects of leakage of streamwater from Clear Creek to the shallow drift. However, comparison of the isotopic data collected for waters from well S8 and Clear Creek displayed no obvious correlation. In fact, the isotopic composition of water from well S8 was relatively stable, displaying none of the major fluctuations that would be expected if significant amounts of Clear Creek streamwater were being mixed with shallow drift water upgradient of well $\mathrm{S} 8$.

The marked differences in dissolved oxygen concentrations and $\mathrm{pH}$ in the shallow ground water and the stream (table 18) indicate that the leakage process is also chemically dynamic. Dissolved oxygen in streamwater is removed almost entirely by reactions in the streambed and shallow aquifer. A discussion of chemical reactions contributing to the observed changes is given in Breen (1988, p. 121). The associated drop in $\mathrm{pH}$ may indicate that, as oxygen depletion is taking place, carbon dioxide concentrations are increasing by nearly an order of magnitude. Specific conductance is virtually the same in the stream and shallow ground water, indicating minor overall changes in the concentrations of dissolved ions as water leaves the stream and enters the shallow ground water beneath the stream. Nevertheless, the $\mathrm{pH}$ and dissolved oxygen changes are indicative of chemical reactions that may negate an assumption of conservative mixing for assessing stream leakage. Thus, comparison of chemical constituent concentrations in streamwater and shallow ground water was not used to assess stream leakage.

Temperature changes between the stream and shallow aquifer at the streambed piczometers (table 18) support the hypothesis that there is interchange of water between the stream and slaallow aquifer. During 16 to 17 July 1985, temperature gradients of -0.4 to $-0.5^{\circ} \mathrm{C} / \mathrm{ft}$ characterize the reach of Killbuck Creek between piezometers K $3 / \mathrm{K} 4$ and $\mathrm{K} 7$. At piezometers $\mathrm{K} 2 / \mathrm{K} 9$, a steeper gradient exists of -0.7 to $-0.8^{\circ} \mathrm{C} / \mathrm{ft}$. These data are consistent with stream gain/loss and seepage-mcter results, indicating that both gaining and losing 
Step 1: Compute area of streambed'for infiltration at base flow.

\begin{tabular}{ll}
$3,000 \mathrm{ft}$ & $\begin{array}{l}\text { Length of reach from KB3 to Lincoln Way West } \\
\text { Average width of stream at base flow } \\
\times 20 \mathrm{ft}\end{array}$ \\
\hline $6 \times 10^{4} \mathrm{ft}^{2}$ & Area of streambed
\end{tabular}

Step 2: Convert leakage rate to Darcian velocity.

$7.5 \mathrm{ft} / 1.3 \mathrm{mo}$. Estimate of downward water velocity from isotopic (lata

x.25

Estimate of porosity

$1.4 \mathrm{ft} / \mathrm{mo}$ Computed estimate of Darcian velocity

Step 3: Compute areally integrated stream-leakage rate.

$1.4 \mathrm{ft} / 2.59 \times 10^{6}$ seconds Unit conversion for Darcian velocity

$\mathrm{x} 6 \times 10^{4} \mathrm{ft}^{2} \quad$ Computed area of streambed

$0.03 \mathrm{ft}^{3} / \mathrm{s} \quad$ Areally integrated rate of stream leakage for reach

reaches characterize Killbuck Creek. Temperature gradients are generally quite steep during the summer months beneath gaining streans (Lapham, 1989, p. 13). The relatively steep gradient at piezometers $\mathrm{K} 2 / \mathrm{K} 9$ is consistent with the head measurements at the site that indicate an upward flow of water from the shallow drift to the streams. The gradients in the reach from piezometers $\mathrm{K} 3 / \mathrm{K} 4$ to $\mathrm{K} 7$ are small relative to $\mathrm{K} 2 / \mathrm{K} 9$ and are indicative of a stream reach that is losing water to the shallowdrift aquifer.

In summary, the isotopic and temperature data for waters beneath Killbuck Creek support the hypothesis that infiltration of strean water to the aquifer is taking place along the reach studied. This is in agreement with hydraulic head measurements and gives additional evidence that stream discharge measurements that indicated a losing reach can be further quantified with the isolopic data. In contrast, the chemical data were not useful in assessing stream leakage rates because chemical reactions continually alter stream water chemistry as the water infiltrates the streambed.

\section{Freshet of February 1985 and Streamwater in the Stratifled Drift}

Specific conductance of water in Killhuck Creek displays little variation, with the exception of the February flood event, during which thic conductance rose and then fell dramatically in response to input of chemically dilute meltwater (fig. 7). The apparent compositional stability implied by the specific conductance valucs shown on figure 7 is probably an artifact of the limited number of conductance measurements made on Killbuck Creek during this study; conduclance can show significant fluctuations during even minor precipitation events. The dilute meltwater of February 1985 was isotopically anomalous, exhibiting extremely light composition (Dysart, 1988, p. 146).

Ground-water chemistry in the drifl was affected by the February 1985 snowinelt and nood. All maximum specific conductance values were measured during the flood event and aquiler resaluration period. Therefore, the dilute streamwater was unrecognizable in the stratified-drift aquifer at the production wells; only minor scasonal variations in specific conductance were recorded in waters from the production wells. Isolopic compositions for ground water in both the stratificd-drift and shale-sandstone aquifers also exhibit only minor seasonal variations, with lighter values 


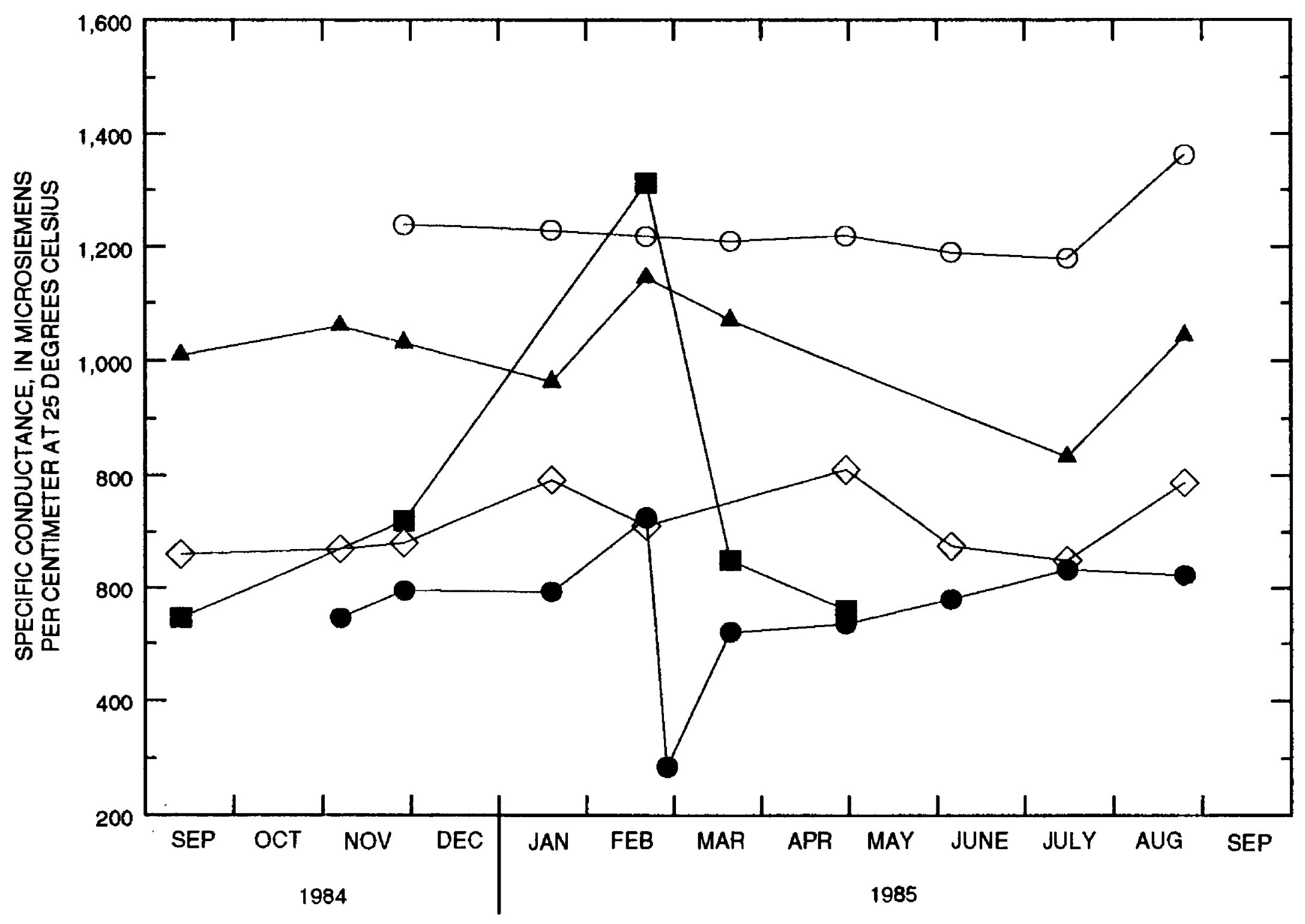

EXPLANATION

- KILLBUCK CREEK--site 1

- WELLD2

$\diamond \diamond$ WELL P4

$\triangle$ WELLP5

$\Theta \bigcirc$ WELL 14

(Wayne county prefix, WN-, is omitted)

Figure 7. Temporal variation of specific conductance of Killbuck Creek (site 1) stream water and ground water in selected wells, Killbuck Creek valley, near Wooster. 
tending to occur during summer and fall months.

Instantaneous-mixing calculations by use of isotopic data gave results that indicated that less than 5 percent of water from the production wells was stream water (Dysart, 1988, p. 148). Only the data collected during February 21 through 26, 1985 , indicate the possibility of appreciable stream infiltration. Median isotope values from six ground-water sites sampled during February 21 through 26 and two surface-water sites sampled on February 21 indicate that 15 percent surface water and 85 percent ground water were in the waters from the production wells (Dysart, 1988, p. 149). Thus, the phrase "appreciable stream infiltration" used by Dysart describes a relatively small percentage of streamwater that remains identifiable as streamwater in the produclion wells.

A reasonable hypothesis to test with isotopic data is whether the isotopic composition of water pumped from a production well corresponds to the average isotopic composition of water in the stream over some period of time. Average-mixing calculations (or arithmetic-mean models) for the period January 1985 to May 1985 that include the freshet give results that indicate the possibility that average isotopic compositions for Killbuck Creek, ground water in deep drift, and ground water from the production wells were the same (Dysart, 1988, p.148). This similarity in average composition indicates stream infiltration, in general, and not just from Killbuck Creek, may be an important component of the drift water.

In summary, water as dilute or as isotopically light as that found in the streams in February 1985 was never observed in samples from any of the wells. This leads to two conclusions:

(1) instantaneous mixing models are not valid for estimating contributions of streamwater in wells, and (2) piston or plug flow of waters with distinctive isotopic compositions is not occurring; rather, a mixing and dispersion process is likely as small amounts of streamwater from Killbuck Creck and Clear Creck infiltrate the stratified drift and recharge the aquifer.

Calcium sulfate-type waters were found in well S3 after the freshet of February 1985. This is the only known occurrence of calcium sulfate-type water in the stratified-drift aquifer, and its origin is related to temporal variations in water levels in the shallow, unconfined part of the stratified-drift aquifer in the north well field. Well S3 was dry prior to February 1985, but water levels rose above the screened interval in response to the freshel. The occurrence of calcium sulfate-type water in the well was attributed to the dissolution of gypsum (calcium sulfate) and other soluble sulfate salts that formed during the dry period that preceded the February recharge event (Breen, 1988).

Other wells whose ground-water chemistry was notably affected by the February 1985 snowmelt and flood included production well P5 and observation well D2. A plot of specific conductance versus time reveals a moderate increase in the specific conductance of water from well P5 (fig. 7). The most notable increase, however, is associated with well D2, which exhibits an almost two-fold increase in specific conductance between November 1984 and February 1985. Intercstingly, this well is the deep well associated with well S3 (pl. 1). Given that $S 3$ contained moderately saline calcium sulfate-type water in February 1985, it was expected that the increase in specific conductance observed in well D2 during and after the February flood event would be due to movement of shallow calcium sulfate-type waters into deeper parts of the aquifer. Although calcium and sulfate concentrations in well D2 did exhibit moderate increases, the major cause of the sharp increase in specific conductance of the D2 well water was the greater than three-fold increases in the sodium and chloride concentrations (table 19).

A tentative hypothesis to explain the conductance increases shown in figure 7 is that the elevated head associated with the February flood event resulted in a short-term increase in the quantity of sodium chloride-type water discharging into the eastern boundary of the north well field. This short-term head increase resulted in a temporary increase in the proportion of bedrockderived sodium chloride-type water in the vicinity of well D2. Supporting evidence for this hypothesis is provided by the observation that the specific conductance of water from well P4 did not increase over this period. This is consistent with the mixing relations discussed above, which suggest that only a minor component of bedrock-derived sodium chloride-type water is present in the water of well P4. 
If the cause of the increase in specific conductance observed in wells D2 and P5 was infiltration of road-salt-contaminated mcliwater, it would be expected that all wells in the north well field would show increases in specific conductance. The limited data available (table 19) indicale that such an increase did not occur. However, the lack of postflood data for the chemical conposition of water in wells P4 and P5 precludes a more rigorous test of this hypothesis.

\section{Results of Steady-State Flow Simulation}

The steady-stale flow simulation was designed to reproduce conditions in the fall of 1984 on the basis of hydrologic data oblained throughout the study area. The following sections discuss the results of this simulalion, particularly with respect to gaining and losing stretches of Killbuck Creek and its tributaries and the amount of water that flowed to simulated drains.

\section{SImulated Stream Gains and Losses}

Gains and losses for stream reaches simulated by the River and Stream Package of the modular model (McDonald and Harbaugh, 1988; and Prudic, 1989, respectively) are summarized in table 20 . Where applicable, model results are presented for reaches corresponding to stream-discharge measurements of tables 3 and 4 . It is to be noled that the stream-discharge measurements represent conditions prevailing on two specific dates (9 September 1985 and 14 August 1986), whereas the simulation pertains to steadystate conditions during the fall of 1984 , and, as such, the measured and simulated values are not directly comparable. On the other hand, both cases are representative of relatively low-flow conditions so that an approximate correspondence between simulated and measured values may be anticipated

According to the simulation, Killbuck Creek lost $1.1 \mathrm{ft}^{3} / \mathrm{s}$ between stream-discharge measurement sites $\mathrm{KB} 1$ and $\mathrm{KB} 6$ in response to ground-water withdrawals at the north well field. Except for a very small loss near the south well field, all other reaches gained. Paired streambed piezometers $\mathrm{K} 2$ and $\mathrm{K} 9, \mathrm{~K} 3$ and $\mathrm{K} 4$, and $\mathrm{K} 5$ and
K6 (pl. 6C) are located along the simulaled losing reach of Killbuck Creek. The paired piezometer water-level measurements (table 5) show that flow was generally downward, indicating that Killbuck Creek was, in fact, losing at these locations. The simulated loss between stream-discharge measurement sites KB3 and KB6 (pl. 1) was about $0.7 \mathrm{ft}^{3} / \mathrm{s}$ as compared with losses of 2.8 and $0.7 \mathrm{Cl}^{3} / \mathrm{s}$ (table 20) measured in September 1985 and August 1986, respectively. Little Killhuck Creek both gained and lost along its simulated length (pl. 2), with a net loss of about $1 \mathrm{ft}^{3} / \mathrm{s}$ in the reach upstream from Route 302 as compared wilh measured losses of 1.4 to $1.5 \mathrm{ft}^{3} / \mathrm{s}$. Clear Creek lost about $1.3 \mathrm{ft}^{3} / \mathrm{s}$ along the entire simulated reach, as compared to measured losses of 0.5 to $0.8 \mathrm{ft}^{3} / \mathrm{s}$; whereas the Apple Creek simulated loss was $0.16 \mathrm{ft}^{3} / \mathrm{s}$. The midvalley tributary stream, which was assigned zero streamflow in its upstream node (pl. 2), gained a small amount of water in the vicinity of the spring located north of Silver Road, and lost this flow further downstream. Thereafter, the midvalley tributary stream was essentially dry. Gaining and losing reaches of Killbuck, Little Killbuck, Clear, and Apple Creeks and the midvalley tributary stream are shown in plate 3 . Stream nodes in which losses occurred are indicated by an asterisk, whereas nodes in which gains occurred are denoted by crosses. Areas devoid of symbols, within the valley, are either constant-head nodes (ponds) or nodes along the midvalley tributary stream in which the stream was dry.

\section{Flow to Drains}

The total flow to drains (pl. 2) for steady-state conditions was $0.67 \mathrm{ft}^{3} / \mathrm{s}$. Most of this flow $\left(0.51 \mathrm{ft}^{3} / \mathrm{s}\right)$ occurred in the set of drains west of the midvalley tributary stream and north of Silver Road. The only available measurement of draindischarge (FT of pl. 1) was made on 9 Seplember 1985 , for the drain field east of the midvalley tributary stream and north of Silver Road. This measured discharge was $0.1 \mathrm{ft}^{3} / \mathrm{s}$ (table 3 ), whereas the simulated discharge was essentially the same. Simulated flow to the remaining drains, south of the north well field, was essentially zero. 
Table 20. Simulated gains and losses for fall 1984 steady-state model compared to estimates from stream-discharge measurements of September 9, 1985, and August 14, 1986

$\left[\mathrm{ft}^{3} / \mathrm{s}\right.$, cubic feet per second; *, measurements were inconclusive based on data in table 3; --, no measurement; NA, not applicable]

\begin{tabular}{|c|c|c|c|c|}
\hline Stream reach & $\begin{array}{l}\text { Measurement } \\
\text { sections on } \\
\text { plate } 1\end{array}$ & $\begin{array}{l}\text { Model reach } \\
\text { (row, column) }\end{array}$ & $\begin{array}{c}\text { Net } \\
\text { simulated } \\
\text { galn (lose) } \\
\left(\mathrm{ft}^{3} / \mathrm{s}\right)\end{array}$ & $\begin{array}{c}\text { Measured } \\
\text { gain or (loss) } \\
\begin{array}{cc}9-9-85 & 8-14-86 \\
\left(f t^{3} / 8\right) & \left(f^{3} / 8\right)\end{array}\end{array}$ \\
\hline
\end{tabular}

Killbuck Creek

Upstream from Silver Rd

Silver Rd. to Rt. 30

Downstream froin Rt. 30

NA
KB1, KB6
KB3, KB6
NA

NA

A

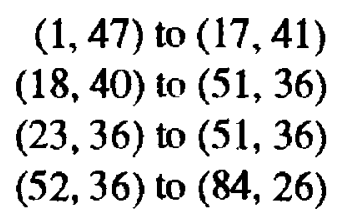

$(1,47)$ to $(17,41)$

$(23,36)$ to $(51,36)$

$(52,36)$ to $(84,26)$
1.78

(1.1)

0.69

0.08
$(1.0)^{*} \quad(0.3)^{*}$

$(2.8)^{*} \quad(0.7)^{*}$

-. $\quad-$

Little Killbuck Creek

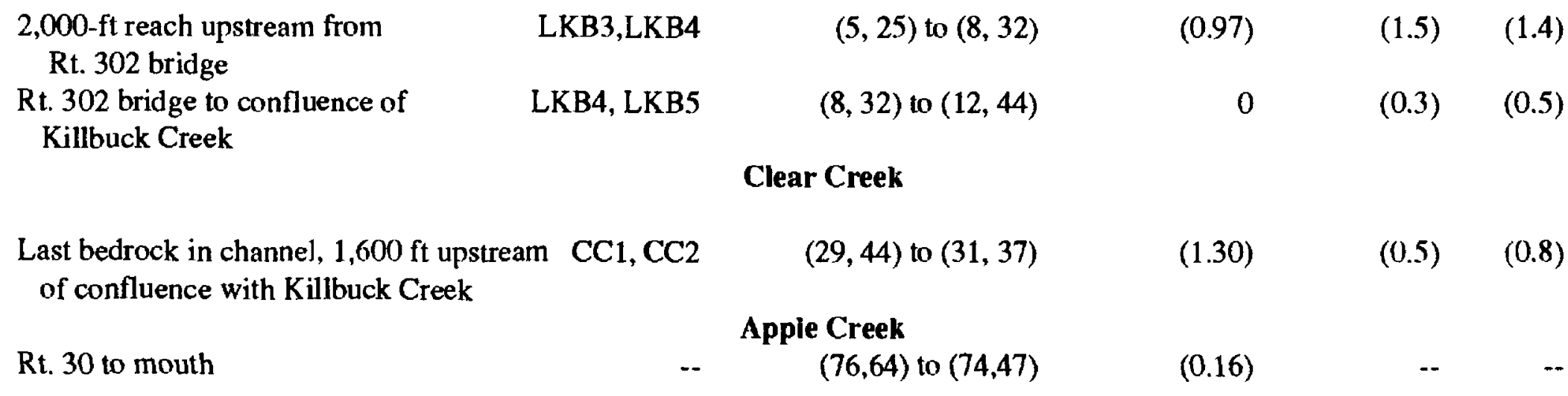

Midvalley tributary stream and Cashey Creek

\begin{tabular}{llrll}
-- & $(12,37)$ to $(14,35)$ & 0.016 & - & - \\
-- & $(15,34)$ to $(20,26)$ & $(0.016)$ & -- & - \\
.- & $(21,26)$ to $(48,33)$ & dry &.- & -- \\
-- & $(49,34)$ to $(51,35)$ & 0.003 & -- & -- \\
\hline
\end{tabular}

\section{Recharge at Land Surface Derived From Local Precipitation}

Simulated recharge to the stratified-drift aquifer in the fall of 1984 includes recharge from precipitation directly on the valley and recharge from upland runoff that originated as precipitation on the uplands and was redirected to the valley floor by the Variable-Recharge procedure. The following sections describe the magnitudes of these recharge components individually, then summarize the spatial distribution and magnitude of all forms of recharge at or near land surface, which include not only infiltration of local precipitation and surface runoff, but also secpage losses from large streams and lateral flow into the upper part of valley fill from the uplands.

\section{Recharge from Precipitation on the Valley Floor}

The distribution of recharge and discharge nodes that resulted from application of the VariableRecharge procedure to fall 1984 steady-stale conditions, superimposed on contours of landsurface elevation, is shown in plate 3 . Nolles in which recharge occurred are indicatcd by an asterisk, whereas nodes in which outwarl seepage occurred are indicated by a cross. Excluding gaining stream nodes, seepage nodes covered 2.5 percent of the valley floor, primarily in lowlying areas adjacent to streams or ponds or nodes designated to receive unchanneled upland runoff. The total amount of water available for recharge applied to Killbuck Creek valley $\left(3.44 \mathrm{mi}^{2}\right.$ in area) was $3.29 \mathrm{ft}^{3} / \mathrm{s}$, of which $0.37 \mathrm{ft}^{3} / \mathrm{s}$ was rejected 
where the water table was at or near land surface, resulting in $2.92 \mathrm{ft}^{3} / \mathrm{s}$ of direct recharge from precipitation on the valley. Over the duration of the simulation ( 92 days), the latter quantity is equivalent to $2.87 \mathrm{in}$. of direct recharge to the valley fill.

\section{Redirected Upland Runoff}

In the uplands, as would be expected, seepage nodes coincide with local and regional topographic lows and the lower slopes of hillsides (pl. 3). These nodes constituted 26 percent of the upland area during the 1984 steady-state conditions.

For the fall 1984 steady-state conditions, the rate of water available for recharge summed over the entire uplands ( $12.2 \mathrm{mi}^{2}$ in area) was $10.45 \mathrm{ft}^{3} / \mathrm{s}$. The disposition of this available recharge is illustrated in figure 8 . The relation of simulated head in layer 1 to land-surface elevation (pl. 3) and the specified depth factor (df $=1.0 \mathrm{ft}$ ) as described by equation 2 , was such that infiltration to the uplands occurred at the rate of $5.70 \mathrm{ft}^{3} / \mathrm{s}$, and $4.75 \mathrm{ft}^{3} / \mathrm{s}$ was rejected. A portion of the infiltrated water moved laterally through layer 1 of the uplands and seeped outward at a rate of $2.87 \mathrm{ft}^{3} / \mathrm{s}$. The total net recharge to the uplands layer 1 was $2.83 \mathrm{ft}^{3} / \mathrm{s}$; a rate cquivalent to about 0.8 in. of recharge over the duration of the simulation. Of the $2.83 \mathrm{ft}^{3} / \mathrm{s}$ of total net recharge, $0.99 \mathrm{ft}^{3} / \mathrm{s}$ was distributed to the valley by way of lateral flow through layer 1 , and a net of $1.84 \mathrm{ft}^{3} / \mathrm{s}$ flowed downward to the upland segment of layer 2 .

The total upland surface runoff $\left(7.62 \mathrm{ft}^{3} / \mathrm{s}\right)$, equal to the sum of rejected recharge $\left(4.75 \mathrm{ft}^{3} / \mathrm{s}\right)$ and seepage $\left(2.87 \mathrm{ft}^{3} / \mathrm{s}\right)$. represents flow that was available to recharge the valley. As discussed previously (table 10), it was assumed that only 50 percent of the water available for recharge to zone 10 (pl. 2) was availablc to recharge the valley. This lost recharge amounted to $0.53 \mathrm{ft}^{3} / \mathrm{s}$, so that $7.09 \mathrm{ft}^{3} / \mathrm{s}$ of runoff was available to recharge the valley. The manner in which the upland surface runoff was allocated to the valley is shown in figure 9. According to the specifications (table 10) as to how this surface runofr was to be distributed, $3.20 \mathrm{ft}^{3} / \mathrm{s}$ and $3.89 \mathrm{ft}^{3} / \mathrm{s}$ were available for unchanneled and channeled surface runoff, respectively, to the valley nodes and tributary streams shown in plate 2 .
For the unchanneled runoff, the relation of the simulated water table in layer 1 , within the valley, to land-surface elevation, and the variable-recharge depth factor (eq. 3) resulted in $1.74 \mathrm{ft}^{3} / \mathrm{s}$ of additional recharge to valley nodes along the valley wall and $1.46 \mathrm{ft}^{3} / \mathrm{s}$ of rejected recharge. This rejected recharge is primarily the result of water levels in nodes allocated to receive unchanneled recharge that were slightly lower than land surface but above the 1-ft depth factor (eq. 3). Must of this rejected recharge occurred in the region adjacent to upland zone 1, west of Killbuck Creek (pl. 2).

The $3.89 \mathrm{ft}^{3} / \mathrm{s}$ of channeled flow was distributed as flow to the upstream nodes of the six tributary streams simulated by the Variable-Recharge procedure (pl. 2 and table 10). Except for the tributary stream emanating from upland recharge zone 4, all of these features lost water to layer 1. Because of the low assigned streambed leakance $(\mathrm{K} / \mathrm{m})$ of $0.1 \mathrm{ft} / \mathrm{d} / \mathrm{ft}$ and narrow stream width of $8 \mathrm{ft}$ (table 11), the simulated streambed conductance (eq. 4) was relatively small, so that the magnitude of net simulated-loss for these streanss was only $0.15 \mathrm{ft}^{3} / \mathrm{s}$. Consequently, the component of upland channeled runoff that did not recharge the valley was $3.74 \mathrm{ft}^{3} / \mathrm{s}$. Of this quantity, about $2 \mathrm{ft}^{3} / \mathrm{s}$ flowed to Killbuck Creek from the tributary streams emanating from upland subbasins 4 and 5 (pl. 2). Thus, about $1.7 \mathrm{ft}^{3} / \mathrm{s}$ flowed from the 4 northernmost tributary streams; $1.5 \mathrm{ft}^{3} / \mathrm{s}$ of which was from the stream emanating from upland basin 6 . The Variable-Recharge procedure does not provide for flow in the downstream reach of these tributary streams to move to their receiving streams. If this flow were applied, some segments of the midvalley tributary stream depicted as diry on plate 3 would probably contain flow. This additional streamflow represents potential recharge to the valley fill that was not accounicel for in the simulation. Given the relatively low streambed leakance of the midvalley tributary siream (table 11), the magnitude of any stream loss would probably be small. 
TOTAL WATER

AVAILABLE FOR RECHARGE

APPLIED TO UPLANDS

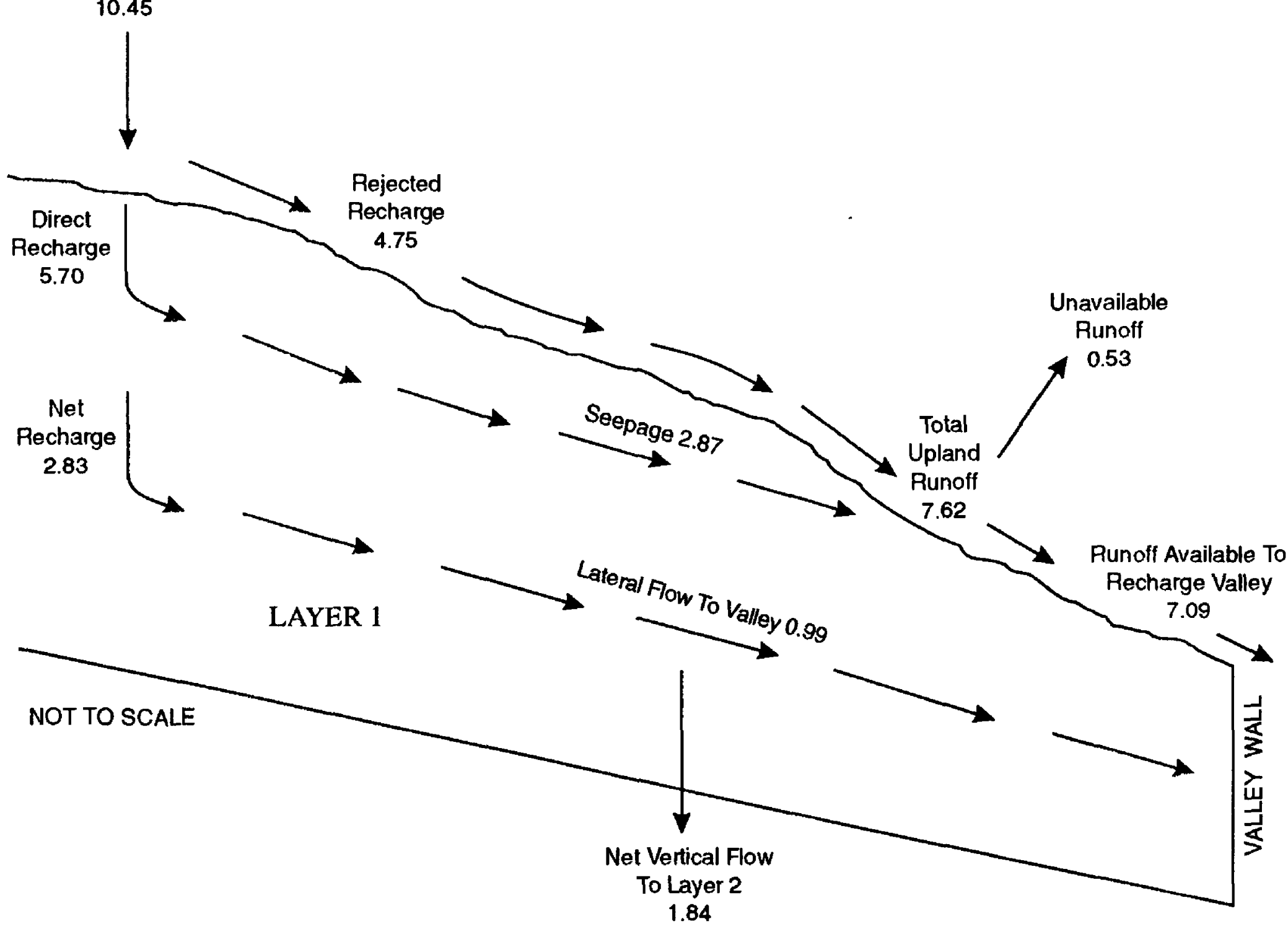

EXPLANATION

$\longrightarrow 4.75$ GENERALIZED DIRECTION AND
MAGNITUDE OF FLOW--in

cubic feet per second

Figure 8. Variable-Recharge procedure allocation of water available for recharge applied to uplands for the steady-state model. 

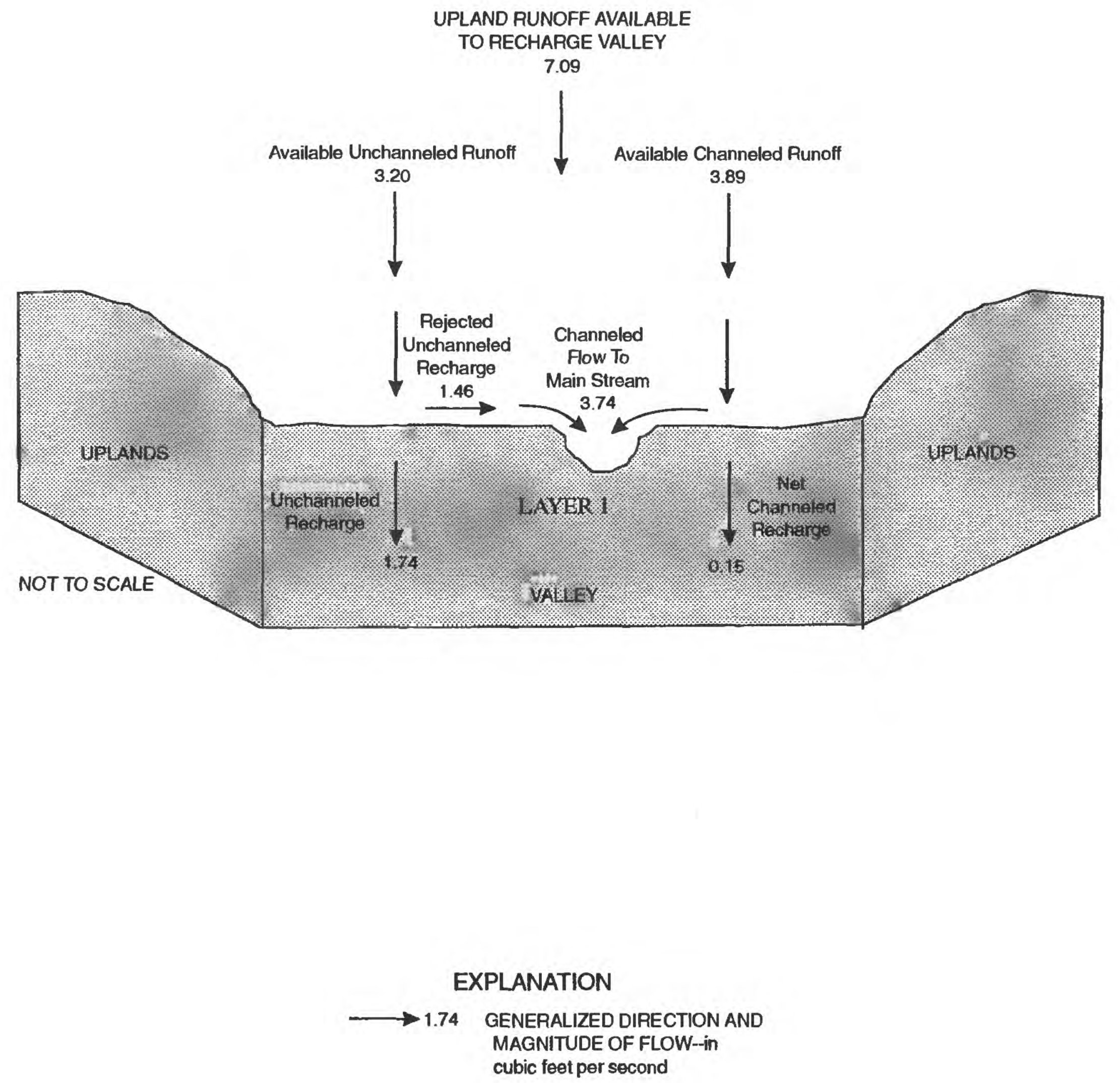

Figure 9. Variable-Recharge procedure allocation of upland runoff available to recharge valley for the steady-state model. 
Spatial Distribution of Recharge at Land Surface from All Sources

Further insight regarding the sources and spatial distribution of recharge to the buried sands and gravels of the Killbuck Creek valley may be obtained from analysis of the simulated flow patterns. As shown in figure 13, the sum of all vertical flow from layer 1 to layer 2, within the valley, was $8.98 \mathrm{ft}^{3} / \mathrm{s}$. Of this quantity, $7.03 \mathrm{ft}^{3} / \mathrm{s}$ occurred north of the ground-water divide (pl. 7) that separates lateral flow to the north and south well fields. In order to determine the location of the primary sources of recharge in the region north of the divide, the percentage of the total recharge $\left(7.03 \mathrm{ft}^{3} / \mathrm{s}\right)$ flowing through each valley node in that region was calculated. The results of this calculation are shown in plate 8 , in terms of ranges of percentage of flow. A similar calculation was made for the region south of the divide, and the resultant percentages are also shown in plate 8 . The data on plate 8 is summarized in table 21 , in terms of the number of nodes and percentage of flow, for each of the selected ranges.

For the north well field, in 98.7 percent of the nodes north of the divide, the per-node percentage of the total vertical-flow was less than 1 percent, and these nodes accounted for 72.4 percent $\left(5.09 \mathrm{ft}^{3} / \mathrm{s}\right)$ of the total vertical-recharge $\left(7.03 \mathrm{ft}^{3} / \mathrm{s}\right)$ to layer 2. The remaining 1.3 percent of the nodes, located primarily beneath Little Killbuck and Clear Creeks, had flow greater than about $0.1 \mathrm{ft}^{3} / \mathrm{s}$ per node and accounted for 27.6 percent $\left(1.94 \mathrm{ft}^{3} / \mathrm{s}\right)$ of the vertical recharge to layer 2 . The latter set of nodes are also located in regions that were assigned relatively high vertical-leakance values (pl. 5 and table 14) and represent windows of small areal extent through which a significant amount of recharge occurred. Most of the simulated vertical recharge north of the divide $\left(5.09 \mathrm{ft}^{3} / \mathrm{s}\right)$ was, however, the accumulation of small vertical flows (less than about $0.01 \mathrm{ft}^{3} / \mathrm{s}$ per node) over a relatively large area.

For the south well field, in 98.7 percent of the nodes south of the ground-water divide, the pernode percentage of the total recharge was less than 1 percent, and these nodes accounted for 90 percent $\left(1.74 \mathrm{ft}^{3} / \mathrm{s}\right)$ of the vertical recharge to layer 2 . The remaining 10 percent $\left(0.19 \mathrm{ft}^{3} / \mathrm{s}\right)$ of the vertical downward flow occurred in 1.3 percent of the nodes. These are located along the valley wall northeast of the south well field, and beneath Apple Creek. Thus, south of the divide, the simulated vertical recharge to layer 2 was primarily in the form of small vertical flows (less than about $0.01 \mathrm{ft}^{3} / \mathrm{s}$ per node), spread over a large area.

The results of this analysis indicate that, to the extent that the simulation is representative of actual conditions, most recharge to the buried sands and gravels was due to the cumulative effect of areally extensive, small-magnitude flows. A small amount of the simulated recharge occurred in the northern part of the model area through local zones of relatively high vertical leakance, most of which are associated with major tributary streams.

\section{Lateral Flow From Uplands to Valley}

The amount of water that flows in the subsurface between the uplands and Killbuck Creek valley is equal to the amount of water that enters the uplands through recharge from precipitation. Chemical and isotopic studies and the steady-state simulation were analyzed to quantify the amount of water that enters the valley. The results of these analyses are presented in the following sections.

\section{Results of Chemical and Isotopic Studies}

Ground-water chemistry at Killbuck Creek valley is defined by the presence of two major water types (Freeze and Cherry, 1979, p. 252). Calcium bicarbonate-type waters are present in the stratifieddrift aquifer in the valley and in the shale-sandstone aquifer above the Wooster Shale on hilltops or hillsides adjacent to the valley. Sodium chloride-type waters are present in the shale-sandstone aquifer underlying the valley (Breen, 1988). Two distinct patterns in ground-water chemistry can be discerned in the stratified-drift aquifer in the vicinity of the north well field: (1) a pattem of increasingly concentrated calcium bicarbonate-type waters towards the southern part of the valley near Lincoln Way West, and (2) a pattern of progressive increases in the sodium and chloride concentrations of ground water towards the eastern edge of the north well field. 
Table 21. Distribution of valley-vertical recharge from layer 1 to layer 2 for areas north and south of ground-water divide

$\left[\mathrm{ft}^{3} / \mathrm{s}\right.$, cubic feet per second]

\begin{tabular}{|c|c|c|c|c|c|c|c|c|}
\hline \multirow{3}{*}{$\begin{array}{l}\text { Range of } \\
\text { total flow } \\
\text { in percent }\end{array}$} & \multicolumn{4}{|c|}{ North of divlde } & \multicolumn{4}{|c|}{ South of divide } \\
\hline & \multirow{2}{*}{$\begin{array}{c}\text { Number } \\
\text { of } \\
\text { nodes }\end{array}$} & \multirow{2}{*}{$\begin{array}{l}\text { Percentage } \\
\text { of total } \\
\text { nodes }\end{array}$} & \multicolumn{2}{|c|}{ Flow } & \multirow{2}{*}{$\begin{array}{c}\text { Number } \\
\text { of } \\
\text { nodes }\end{array}$} & \multirow{2}{*}{$\begin{array}{c}\text { Percentage } \\
\text { of tolal } \\
\text { nodes }\end{array}$} & \multicolumn{2}{|c|}{ Flow } \\
\hline & & & Percent & $\mathrm{f} / \mathrm{s} / 8$ & & & Percent & $7 \mathrm{f} / \mathrm{s}$ \\
\hline$<0.1$ & 813 & $\overline{83.6}$ & 22.1 & 1.55 & 195 & 32.7 & 12.6 & 0.24 \\
\hline $0.1-0.5$ & 108 & 11.1 & 25.7 & 1.81 & 373 & 62.6 & 63.3 & 1.23 \\
\hline $0.5-1.0$ & 39 & 4.0 & 24.6 & 1.73 & 20 & 3.4 & 14.1 & 0.27 \\
\hline $1.0-2.0$ & 8 & $<1$ & 11.7 & 0.82 & 8 & 1.3 & 10.0 & 0.19 \\
\hline $2.0-3.0$ & 1 & $<1$ & 2.5 & 0.18 & 0 & 0 & 0 & 0 \\
\hline$>3.0$ & 3 & $<1$ & 13.4 & 0.94 & 0 & 0 & 0 & 0 \\
\hline TOTALS & 972 & 100 & 100.0 & 7.03 & 596 & 100 & 100.0 & 1.93 \\
\hline
\end{tabular}

The calcium bicarbonate pattem is not believed to be related to lateral flow of water from the uplands to the valley. The pattern is defined by decreases in ground-water $\mathrm{pH}$, increases in specific conductance, and increases in calcium, iron, manganese, and bicarbonate concentrations. This pattem is illustrated by comparing the composition of the water in upvalley well D6 with the composition of water in downvalley wells D10 and D12 (table 19). The composition at D10 and D12 is due to the chemical evolution of calcium bicarbonate waters as the ground water flows toward the production wells. If water in well D6 is presumed to represent the composition of waters far upgradient from the production wells, then the observed chemical trends indicate that gaseous carbon dioxide is being added to the ground water, resulting in a decrease in ground-water $\mathrm{pH}$. Acidity associated with the elevated carbon dioxide levels is quickly neutralized by reaction with calcium carbonate, resulting in the observed increases in the calcium and bicarbonate concentrations of ground water. Observed increases in iron and manganese concentrations probably result from dissolution of iron-rich chlorite and iron/manganese oxides and a trend towards slightly more reducing conditions in the southern part of the aquifer (Breen, 1988).

The sodium chloride pattern is caused by lateral flow from the uplands to the valley. The pattem is illustrated by specific conductance data obtained from the production wells (fig. 10). The process responsible for this pattem is mixing between calcium bicarbonate-type waters of the stratifieddrift aquifer and sodium chloride-type waters from the shale-sandstone aquifer (Breen, 1988).
Mixing of the two water types is clearly defined on a plot of sodium versus chloride (fig. 11). Data for produc- tion wells P4 and P5 fall on a mixing line defined by bedrock water (well 14) and representative drift water (well D6) (fig. 11). Compositional data indicate that well water from production well P5 contained about 30 percent sodium chloride-type water, whereas the production well located at the west edge of the north well field (well P4) contained less than 10 percent of sodium chloride component (fig. 11). The overall composition of the produc- tion well waters indicates that the dominant com-ponent of both waters was a mixture of calcium bicarbonate-type waters derived from both upvalley and downvalley parts of the stratified-drift aquifer (Breen, 1988).

The percentage of bedrock-derived sodium chloride-type water was estimated also by use of isotopic data by Dysart (1988). No evidence for a bedrock-derived sodium chloride component in production well $\mathrm{P} 4$ is indicated by the $\delta^{18} \mathrm{O}$ chloride mixing relations shown on figure 12 . Evidence to support the hypothesis that bedrockinfluenced water reaches the production wells on the east side of the north well field are (1) production wells P5, P6, P7, and 17 arc completed closer to the till-bedrock contact than the other production wells, and (2) the till at the base of the stratified drift is thinner and more permeable on the east side of the north wellfield than on the west side of the Killbuck Creek valley. These arguments are based on the geologic section (fig. 2) and on the presence of permeable kame material on the side of the valley east of well 17 . 


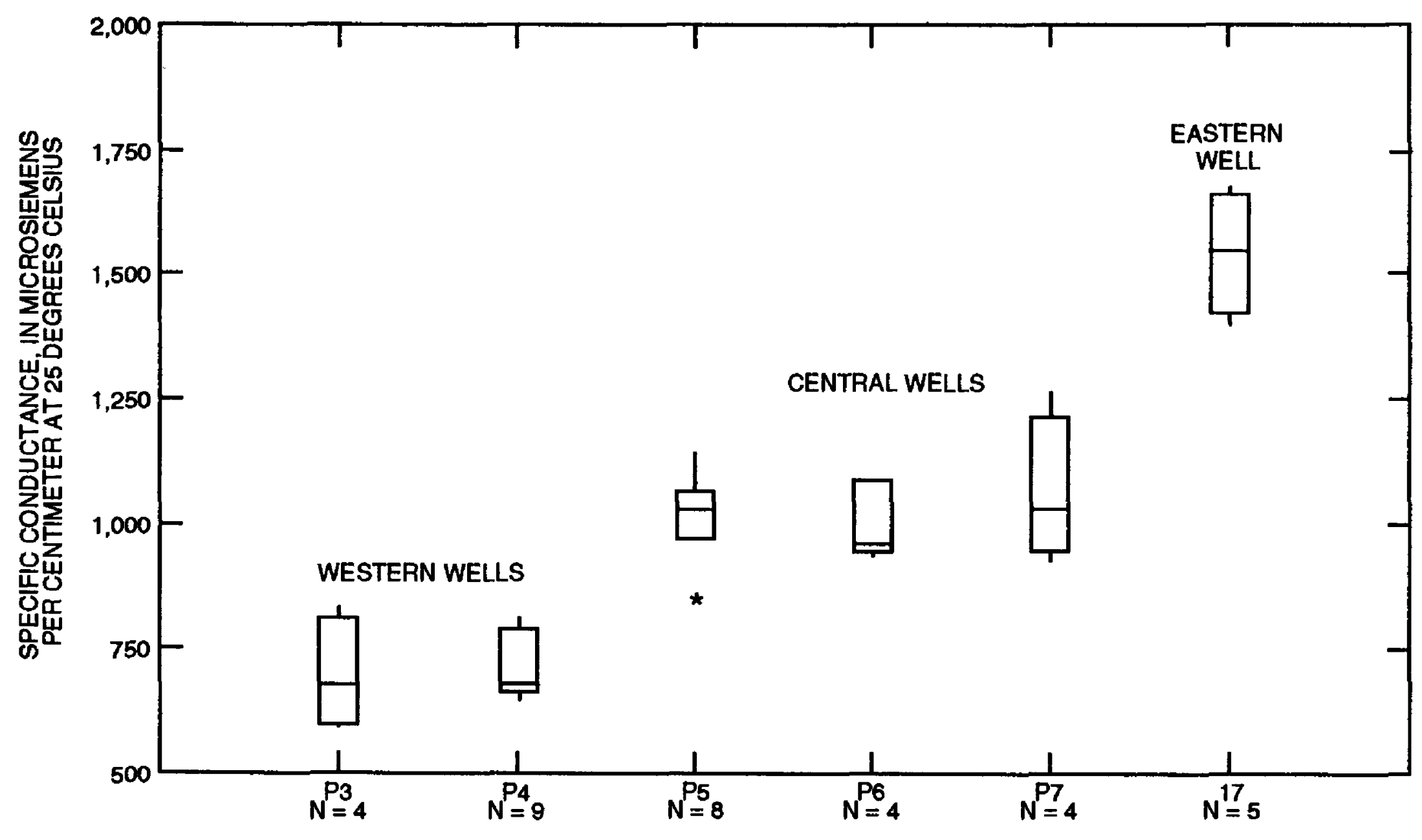

PRODUCTION-WELLL IDENTIFIER AND NUMBER OF OBSERVATIONS

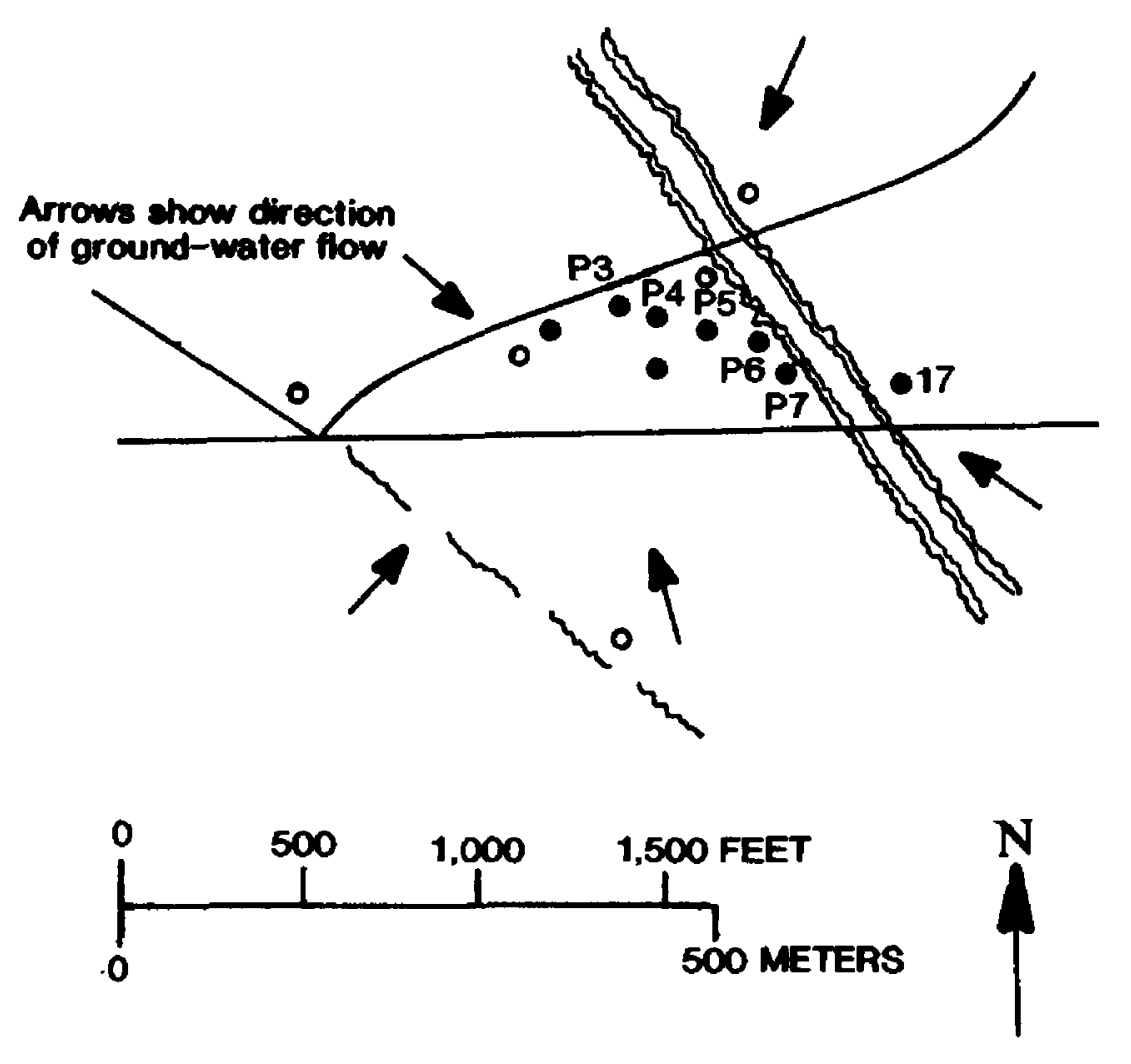

EXPLANATION

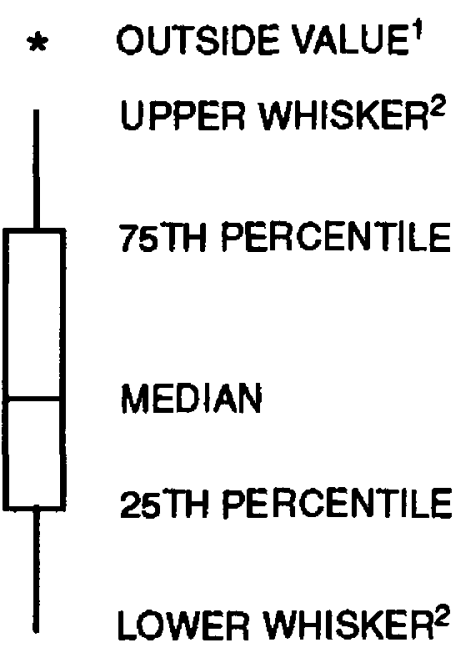

${ }^{1}$ An outside value is defined as $>1.5$ and $\leq 3$ interquartile ranges from the box.

2Upper whisker is defined as the largest data point less than or equal to the upper quartile plus 1.5 times the interquartile range. Lower whisker is minus 1.5 times the interquartile range.

Figure 10. Variation in specific conductance measured at production wells and assignment of western, central, and eastern designations to production waters. (Location of map of north well field is shown in pl. 1.) 


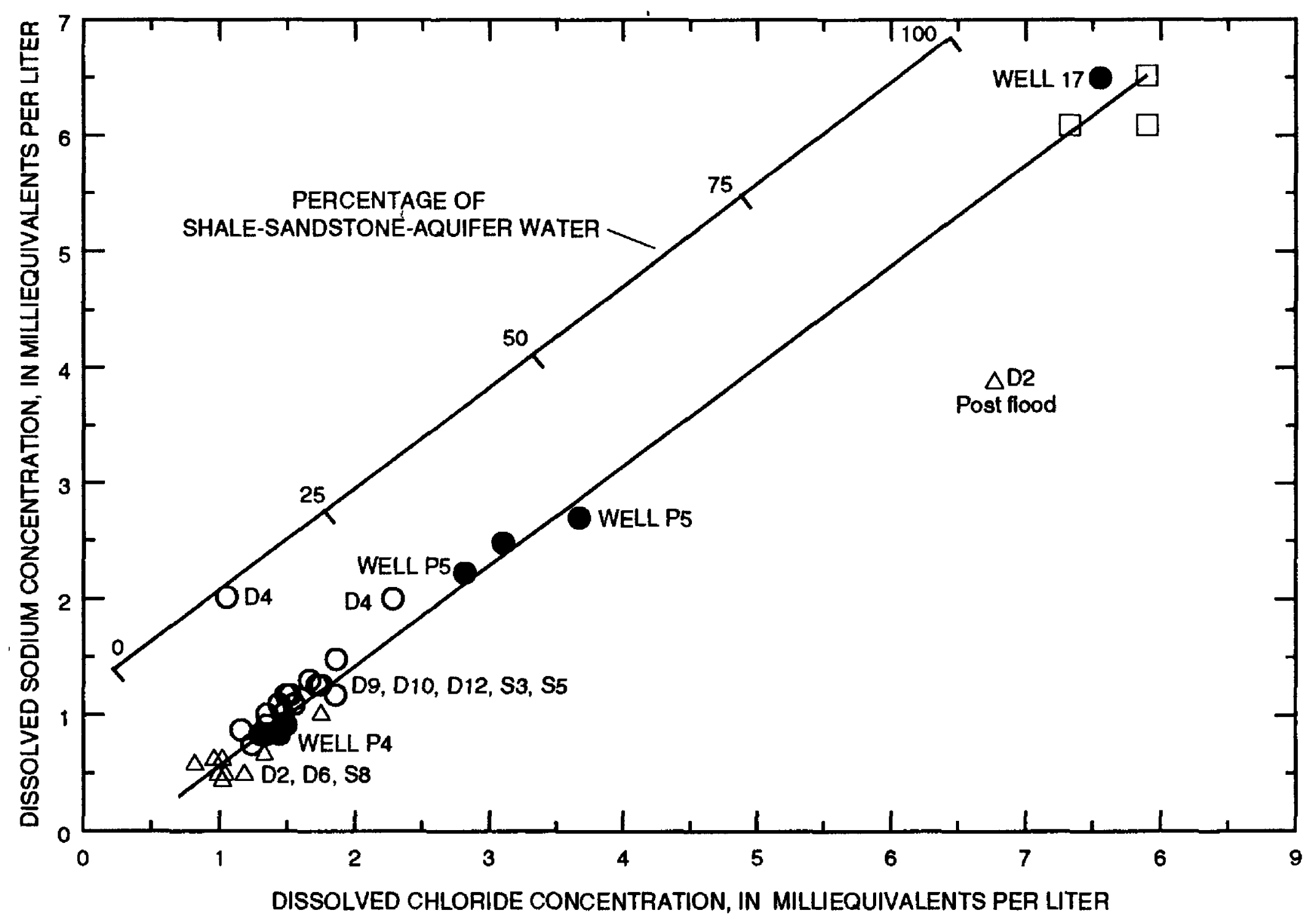

\section{EXPLANATION}

$\triangle$ DEEP DRIFT--note well identifier

O DEEP AND SHALLOW DRIFT--note well identifier

- PRODUCTION

$\square$ SHALE-SANDSTONE BEDROCK WELL 14

(Wayne county prefix, WN-, is omitted)

Figure 11. Mixing plot based on sodium and chloride milliequivalents in ground water and the concept of a percentage of shale-sandstone-aquifer water in stratified-aquifer wells. 


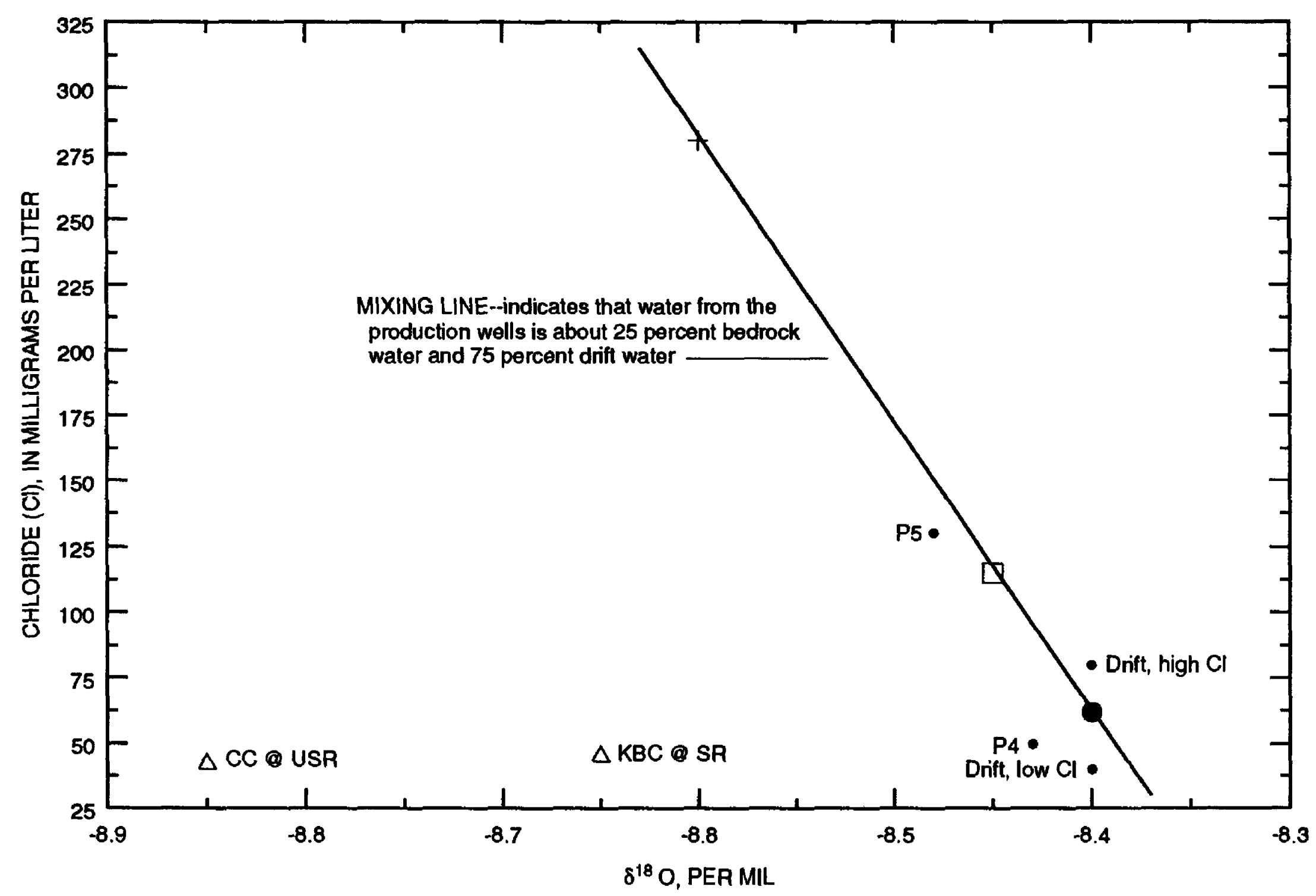

EXPLANATION

PRODUCTION WELLS, MEDIAN

DRIFT, MEDIAN (OF ALL OBSERVATION WELLS)

+ BEDROCK, WELL 14--Wayne county prefix, WN-, is omitted

$\triangle$ SURFACE-WATER SITE AND NUMBER

- DRIFT, AND IDENTIFIER

Figure 12. Mixing relation between shale-sandstone bedrock water and stratified-drift water near Wooster, Ohio, February 21 to 26, 1985, and comparison to water in Clear Creek and Killbuck Creek based on mixing line using chloride concentrations and $\delta^{18} O$ values. (From Dysart, 1988, p. 153.) 
Isotopic data for tritium also indicate that lateral flow of ground water from the shalesandstone bedrock aquifer to the stratified-drift aquifer is occurring. Evidence that ground water flows laterally through the shale-sandstone aquifer from upland areas into the stratified drift over hydrologically short time scales (years to decades) is provided by the concentration of the radioactive hydrogen isotope tritium in water collected from well 14. In January 1985 , water from well 14 contained $20 \mathrm{TU}$ (tritium units) ( $1 \mathrm{TU}=3.24$ picocuries per liter), which indicates that a significant component of water from well 14 entered the bedrock aquifer after the advent of atmospheric nuclear testing in 1953 (table 19). Drift ground water at wells D2, S5, and D6 contained between 31 and 43 tritium units (table 19). Due to the transient nature of the tritium input function and limitations imposed by a single sample set, more precise estimates of the age of the waters cannot be obtained; both the drift and the bedrock water may have entered the respective aquifers at any time between 1953 and 1985 . Well 14 is located at the west edge of Killbuck Creek valley, right at the base of the adjacent hillside (pl. 1), and the importance of the tritium data from this well is that it shows that laterally directed flow of ground water through the bedrock toward, and presumably into, the valley fill is occurring. This evidence combined with the chemical data implies that the bedrock aquifer should not be viewed as a boundary to flow to the stratified-drift aquifer. The implication would be stronger if sources of sodium and chloride other than from the bedrock were considered and evaluated.

The possibility that sodium and chloride derived from road salt applied to Lincoln Way West was affecting the ground-water quality of the production wells was considered. However, simple mass balance calculations utilizing the concentration of chloride in production well P5 (approximately $120 \mathrm{mg} / \mathrm{L}$; table 19) and a pumping rate of $1.25 \mathrm{ft}^{3} / \mathrm{s}$ (table 8 ) indicate that salt applications in excess of one ton per day would be required annually to maintain the sodium and chloride concentrations observed in well P5 alone. By including other high-chloride waters and pumping rates for wells $17, \mathrm{P} 7$, and $\mathrm{P} 6$, the estimate of one ton per day of road salt would need to be tripled to provide salt in the water produced from the 4 wells combined. Given the limited number of days in the year during which road salting occurs, it is unlikely that application of salt to roads near the well field is the source of sodium and chloride in production wells of the north well field. The potential also exists for contributions of sodium and chloride on the east side of the valley from the road salt storage facility located on the south side of Lincoln Way, east of the north well field (pl. 1). Geophysical surveys in the 1950's traversed near the facility, and no highly conductive aquifer characteristics attributable to high conductance water in the aquifer were noted. Little else is known of ground-water chemistry, particularly sodium and chloride concentrations in the drift aquifer near the storage facility.

Oil and gas brine spilled, leaked, or otherwise discharged from deep oil and gas wells is conceivably a source of the sodium and chloride in the production wells. Numerous oil and gas wells line the margins of the Killbuck Creek valley near Wooster. Additional data are needed to determine whether the chemical signature of sodium chloride in production well water indicates that brine from oil and gas wells near the north well field is a source of the sodium and chloride.

The stratified-drift aquifer contains a readily discernible component of bedrock-derived sodium chloride-type water where extensive pumping occurs adjacent to the drift/bedrock interface. The best example of this pattern is provided by well 17 , an industrial well that is located east of Killbuck Creek near the eastern edge of the valley (pl. 1 and fig. 2). This well is pumping water from near the base of the glacial drift deposits, and its water contains sodium and chloride concentrations that are almost identical to those observed in the well completed in shale bedrock (well 14). Further west of the valley wall, the chemical and isotopic mixing models of Breen (1988) and Dysart (1988) indicate that bedrock-derived sodium chloride-type water may comprise 25 to 40 percent of the ground water pumped by production wells located in the central and eastern parts of the north well field (figs. 11 and 12). Chemical data indicate that the proportion of bedrock-derived sodium chloride water in groundwater of the north well field increases from west to 
east, in the direction of the valley wall (fig. 10). This indicates that pumping is significantly increasing the rate of vertical and lateral leakage from bedrock strata in the vicinity of the well field. Assuming about $2 \mathrm{Mgal} / \mathrm{d}$ is pumped from the central and eastem parts of the north well field, about $0.5 \mathrm{Mgal} / \mathrm{d}$, or $0.75 \mathrm{ft}^{3} / \mathrm{s}$, is derived from bedrock water with a sodium chloride water-type.

Leakage of water with a saline component into freshwater aquifers caused by pumping has been documented in the literature for several types of hydrogeologic settings. The upconing of saline water into freshwater beneath a pumped well is described in general by Heath (1983, p. 68, 78, and 79 ) and in more detail by Bennett and others (1968). Pumping in a coastal hydrogeologic setting has resulted in saline-water influx to the freshwater aquifers of Cape Cod, Mass. (Reilly and others, 1987). In a hydrogeologic setting similar to the Killbuck Creek valley, saline water in stratified drift in Dale Valley, New York, was hypothesized to be originating either naturally in bedrock or from brine wells in the vicinity (Randall, 1979, p. 58). The bedrock was the likely source; however, the evidence was not definitive. In the glacial-outwash hydrogeologic setting near Vincennes, Ind., saline water is probably entering the outwash aquifer from fractures in the underlying sandstone bedrock (Shedlock, 1980). The source of salinity near Vincennes was related to an area of abandoned oil wells; however, the exact source could not be determined.

\section{Results of Steady-State SImuiation of Flow to Valley}

The Variable-Recharge procedure is a highly simplified approach to simulate the magnitude and distribution of upland infiltration and surface runoff. Most of the factors that are the concern of hillslope and unsaturated zone hydrology and which govern the detailed magnitude and distribution, in time and space, of infiltration and surface runoff are ignored. Consequently, the most that can be expected from the Variable-Recharge procedure is that the simulated effects are a reasonably good, large-scale approximation of actual processes. A measure of how well these processes are simulated can be obtained from an analysis of recharge and surface runoff behavior within individual upland subbasins. Table 22 shows the simulated surface runoff, net recharge, and lateral flow for each upland subbasin of the steady-state simulation. In upland subbasins $1,4,5,6,8$, and 10 (pl. 2), the simulated steady-state component of surface runoff was a relatively high proportion of the water available for recharge, whereas the component of net upland recharge was proportionally low. Each of these subbasins contains at least one relatively large stream channel. In subbasins 12 through 15 , the simulated component of surface runoff was a small proportion of the water available for recharge, and the net upland recharge component was proportionally large. Except for upland zone 12, these subbasins lack stream channels. The remaining subbasins $(2,3,7,9$, and 11, pl. 2$)$ contain relatively small stream-channels, and the proportion of simulated surface runoff and net upland recharge is roughly the same. Thus, in most cases, the distribution of surface runoff and net upland recharge is, in a qualitative sense, that which would be expected given the topographic character of each subbasin.

The net upland recharge ultimately recharges the valley-fill at the valley wall by way of lateral flow within the uplands. The simulated lateral flow to the Killbuck Creek valley, for each of the upland zones (pls. 2 and 4) and for each layer, is given in table 22 . The western uplands (hydraulic conductivity zones 41 through 51) contributed a total of $1.49 \mathrm{ft}^{3} / \mathrm{s}$ to the valley, or $0.53,0.53$, and $0.43 \mathrm{ft}^{3} / \mathrm{s}$ to layers 1,2 , and 3 , respectively. The eastern uplands (hydraulic conductivity zones 20 and 52 through 55) contributed a total of $1.35 \mathrm{ft}^{3} / \mathrm{s}$ to the valley or $0.47,0.54$, and $0.34 \mathrm{ft}^{3} / \mathrm{s}$ to layers 1,2 , and 3 , respectively. Upland hydraulic conductivity zones 20 and 44 through 53 drain to regions that are primarily north of the ground-water divide separating the north and south well fields. These upland zones contributed a total of $2.02 \mathrm{ft}^{3} / \mathrm{s}$ to the valley, or $0.83,0.71$, and $0.48 \mathrm{ft}^{3} / \mathrm{s}$ to layers 1,2 , and 3 , respectively. Upland hydraulic conductivity zones 41 through 43,54, and 55, which drain to areas south of the divide, provided a total of $0.82 \mathrm{ft}^{3} / \mathrm{s}$ of lateral flow to the valley, or $0.17,0.36$, and $0.29 \mathrm{ft}^{3} / \mathrm{s}$ to layers 1,2 , and 3 , respectively. 


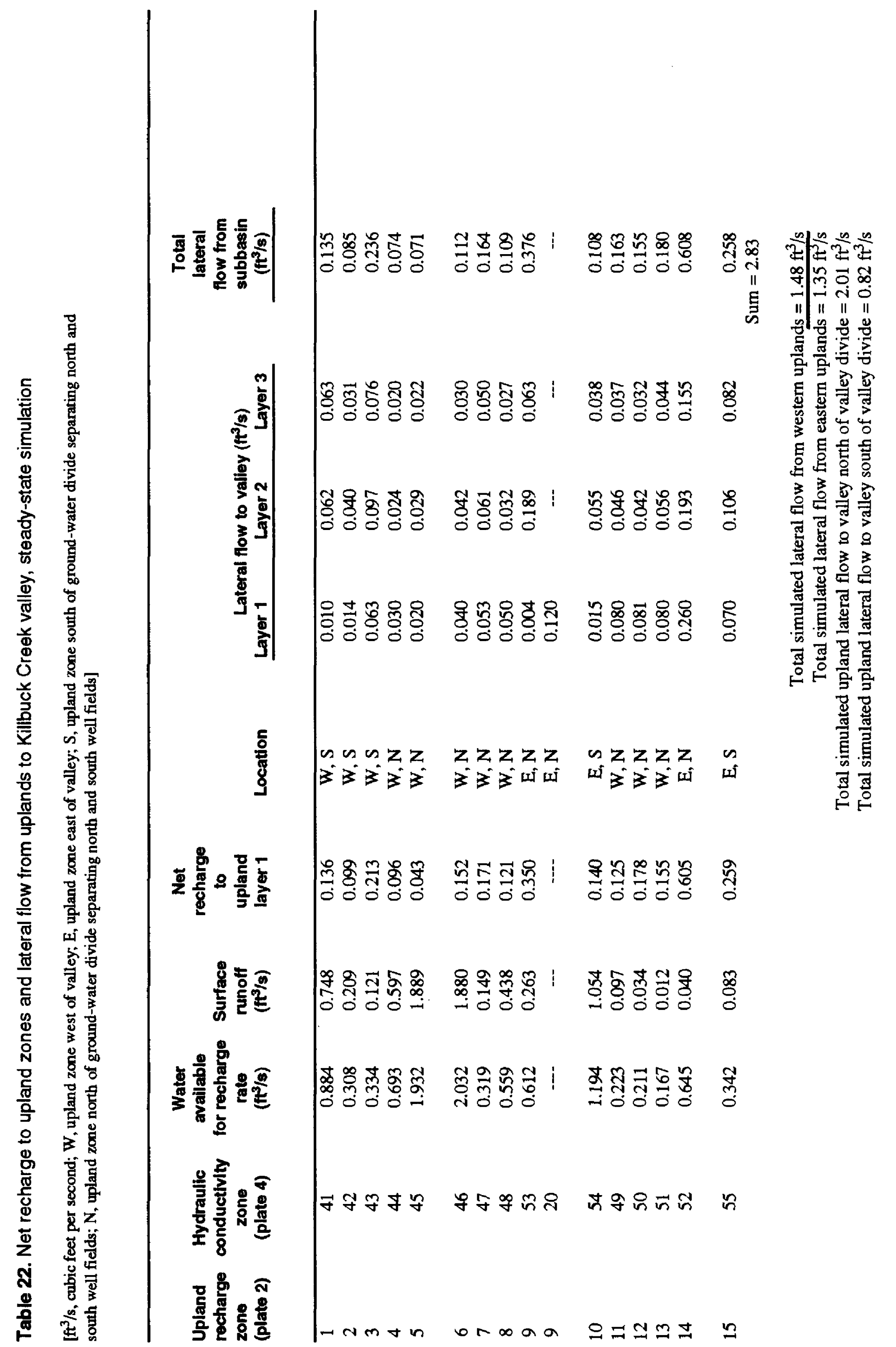


If there were no lateral flow between upland subbasins, then the lateral flow emanating from a particular subbasin would equal the net recharge to the subbasin. As shown in table 22, there was a small amount of flow between subbasins. This lateral flow between upland subbasins could be the result of the relatively large model-cell size in the uplands and the consequent discretization errors in delineating the boundaries between subbasins. On the other hand, the effects of topography on a flow system generally attenuate with depth so that the lateral flow could be representative of regional flow between subbasins.

\section{Simulated Steady-State Ground-Water Budgets}

The simulated steady-state water budget for the stratified drift is summarized in table 23. The total flow to the stratified drift from all sources was about $12.5 \mathrm{ft}^{3} / \mathrm{s}$. This total flow consists of the following components: direct recharge $\left(2.92 \mathrm{ft}^{3} / \mathrm{s}\right)$; unchanneled and channeled recharge from upland sources $\left(1.91 \mathrm{ft}^{3} / \mathrm{s}\right)$; losses from streams and ponds $\left(4.41 \mathrm{ft}^{3} / \mathrm{s}\right)$; lateral boundary fluxes through all layers $\left(0.39 \mathrm{ft}^{3} / \mathrm{s}\right.$, table 8$)$; and lateral flow from the uplands through all layers $\left(2.83 \mathrm{ft}^{3} / \mathrm{s}\right.$, fig. 11). The total lateral flow from the uplands $\left(2.83 \mathrm{ft}^{3} / \mathrm{s}\right)$ represents about 23 percent of all inflows to the stratified drift. Of the total inflow to the stratified drift (about $12.5 \mathrm{ft}^{3} / \mathrm{s}$ ), $7.9 \mathrm{ft}^{3} / \mathrm{s}$ may be attributed to sources originating in the uplands (table 23). Thus, the upland sources represent about 63 percent of the total recharge to the stratified drift.

The simulated water budget for the entire model, including the vertical interchange between model layers and lateral flows into the valley, is given in figure 13. The quantity termed "lotalrecharge to valley at land surface," of magnitude $9.24 \mathrm{ft}^{3} / \mathrm{s}$, consists of all inflow terms of table 23 except lateral flow from the uplands and underflow. The sum of all lateral flows from the uplands to the valley was $2.83 \mathrm{ft}^{3} / \mathrm{s}$, equivalent to the net recharge to the uplands.

Table 23. Water budget for stratified drift, steady-state simulation

[ft ${ }^{3} / \mathrm{s}$, cubic feet per second; in., inches; $*$ upland sources of recharge]

\begin{tabular}{|c|c|c|c|}
\hline \multirow{2}{*}{$\frac{\text { Inflow, } \mathrm{ft}^{3 / 8}}{\text { Direct recharge }}$} & \multicolumn{3}{|c|}{ Outfiow, $\mathrm{ft}^{3} / \mathrm{s}$} \\
\hline & 2.92 (2.91 in.) & Seepage & 0.71 \\
\hline $\begin{array}{l}\text { Recharge from upland } \\
\text { unchanneled sources }\end{array}$ & $1.74^{*}$ & & \\
\hline $\begin{array}{l}\text { Recharge from upland } \\
\text { channeled sources }\end{array}$ & $.17 *$ & $\begin{array}{l}\text { Discharge to channels of } \\
\text { minor tributaries }\end{array}$ & .02 \\
\hline $\begin{array}{l}\text { Recharge from Little Killbuck, } \\
\text { Clear, and Apple Creeks }\end{array}$ & $2.99 *$ & Discharge to Little Killbuck Creek & .74 \\
\hline Recharge from Killbuck Creek & 1.10 & Discharge to Killbuck Creek & 1.86 \\
\hline $\begin{array}{l}\text { Recharge from constant heads } \\
\text { (ponds) }\end{array}$ & .32 & Discharge to drains & .67 \\
\hline Upstream underflow & .22 & & \\
\hline $\begin{array}{l}\text { Clear Creek and Apple Creek } \\
\text { underflow }\end{array}$ & $.17 *$ & & \\
\hline Lateral flow from uplands & $2.83^{*}$ & $\begin{array}{l}\text { Pumpage (north and south } \\
\text { well fields) }\end{array}$ & 8.50 \\
\hline & $T A L=12.5$ & TOTAL $=$ & 12.5 \\
\hline
\end{tabular}




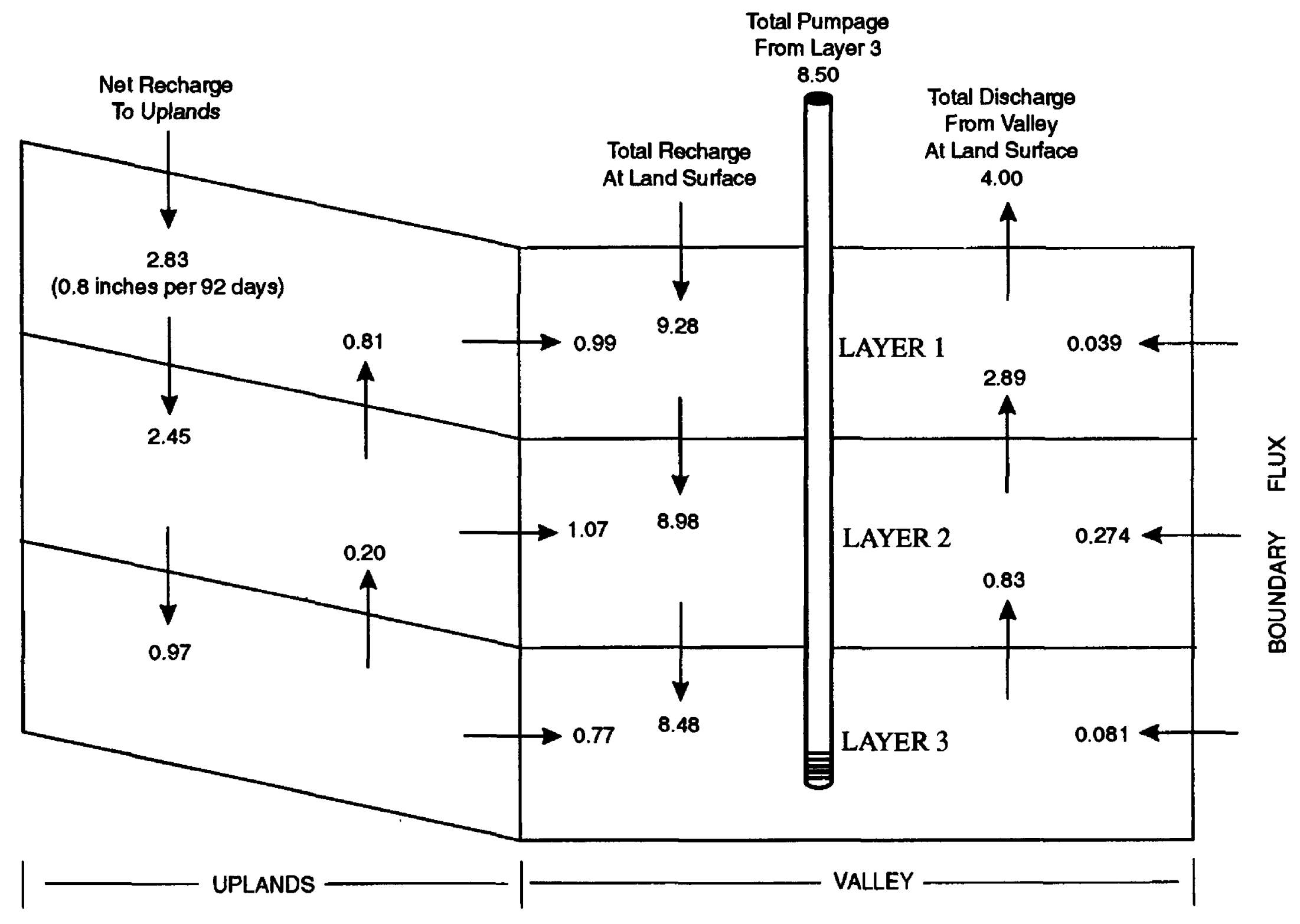

EXPLANATION

$\begin{array}{ll}\longrightarrow 1.07 & \text { DIRECTION AND MAGNITUDE } \\ \text { OF FLOW-in cubic feet } \\ \text { per second }\end{array}$

Figure 13. Simulated water budget for the steady-state model. 


\section{SUMMARY}

Infiltration of streamwater, areal recharge in the uplands and valley, and lateral subsurface flow from the uplands to the valley were evaluated as sources of water to the stratified-drift aquifer in the Killbuck Creek valley near Wooster, Ohio. The aquifer is stressed by pumping from two well fields. Simulation of ground-water flow is the primary technique described in this report for evaluating sources of water; however, chemical and isotopic studies were also used to indicate important factors to consider in flow simulations. Chemical and isotopic studies also provided a means to constrain and evaluate the results of the computer simulations.

The USGS modular model was used to construct a three-layer steady-state ground-water-flow model of the Killbuck Creek valley aquifer and the adjoining uplands to simulate average hydraulic conditions prevailing during the fall of 1984 . The interaction of Killbuck Creek and streams tributary to Killbuck Creek with the aquifer, as well as the hydraulic effects of a network of subsurface drains adjacent to the north well field, were simulated with the River, Stream, and Drain packages of the modular model. Pumpage in the steady-state simulation was 5.5 and $3.0 \mathrm{ft}^{3} / \mathrm{s}$ from the north and south well fields, respectively. Initial estimates of horizontal hydraulic conductivity were based on well logs, aquifer tests, and electrical-resistivity data. For segments of the model in which little or no information was available, hydraulic properties were estimated primarily by model calibration. Model layer 1 in the valley is a confining unit that overlies the gravel aquifers in layers 2 and 3, which are tapped by the production wells. As a result of the calibration process, simulated hydraulic conductivity within the valley ranged from 0.25 to $100 \mathrm{ft} /$ day for layer $1 ; 5$ to $500 \mathrm{ft} / \mathrm{d}$ for layer 2 ; and 5 to $700 \mathrm{ft} / \mathrm{d}$ for layer 3 . Vertical leakance within the valley varied from $2.5 \times 10^{-9}$ to $2.5 \times 10^{-4}(\mathrm{ft} / \mathrm{s}) / \mathrm{ft}$ between layers 1 and 2 and from $1 \times 10^{-9}$ to $1 \times 10^{-5}(\mathrm{ft} / \mathrm{s}) / \mathrm{ft}$ between layers 2 and 3 . These values reflect the high degree of spatial heterogeneity of the drift deposits and of their hydraulic properties. In the uplands, uniform values of $0.3 \mathrm{ft} /$ day and $1 \times 10^{-9}(\mathrm{ft} / \mathrm{s}) / \mathrm{ft}$ were used for the horizontal hydraulic conductivity within each layer and vertical leakance between layers, respectively.

For the steady-state simulation, the model was calibrated by minimizing the mean absolute deviation between head measurements assumed to be representative of fall 1984 average conditions and the corresponding model heads. Mean absolute deviations for observation wells in layers 2 and 3 near the north well field were 1.4 and $1.6 \mathrm{ft}$, respectively, and for observation wells in layers 2 and 3 near the south well field were 1.3 and $0.7 \mathrm{ft}$, respectively. Overall, mean absolute deviation for all observation wells within the valley for layers 2 and 3 was $1.1 \mathrm{ft}$. Mean absolute deviation with respect to heads measured in streambed piezometers was $0.4 \mathrm{ft}$, and with respect to nine observation wells located in the uplands was $10.8 \mathrm{ft}$.

To provide further confidence in the hydraulic properties derived in the steady-state simulation, a transient simulation of a rapid snowmelt event, over the time period 23 February through 5 March, 1985, was constructed. As a result of the melting of an 18-in. snowpack, water levels rose considerably throughout the valley. The stresses applied to the model consisted of a water available for recharge flux of $2.2 \times 10^{-7} \mathrm{ft} / \mathrm{s}$, an increase of stream-surface elevation of 2 to $3 \mathrm{ft}$ relative to steady-state levels, and elimination of pumping from the south well field. The fall 1984 steady-state heads were the initial condition for the transient simulation. Water levels measured in 13 observation wells in the vicinity of the north well field, on 5 March, 1985 , and the difference between these water levels and the average water levels measured during the fall of 1984, were used for comparison with simulated results. The transient model fit, in terms of mean absolute deviation between measured and simulated heads, was $1.8 \mathrm{ft}$ and between the measured and simulated rise in head was $2.5 \mathrm{ft}$. The fit was relatively good for individual wells except observation well S13, in which simulated head and rise in head was considerably higher than the measured values. Consequently, a second transient simulation was run wherein the quantity of unchanneled runoff from the upland zone adjacent to the model region near the well was considerably reduced. The effect of this reduced runoff was to significantly lower the simulated head and head rise in the vicinity of S13 and to affect the head distribution marginally in other areas. The overall 
model fit for this second case was $1.3 \mathrm{ft}$ for simulated head and $1.4 \mathrm{ft}$ for simulated rise in head. These results indicate that, if the simulated storage properties are characteristic of the aquifer materials, the hydraulic properties used in the simulation are a plausible representation of the actual setting.

Infiltration of streamwater is a source of recharge to the stratified-drift aquifer. The locations of losing reaches of Killbuck Creek, Little Killbuck Creek, and Clear Creek, on the basis of steady-state simulations, generally correspond to losing reaches indicated by stream discharge and streambed piezometer measurements. Streamflow measurements on 14 August 1986 for Killbuck Creek indicate a net loss of $0.7 \mathrm{ft}^{3} / \mathrm{s}$ (10 percent of flow); the simulation approximately replicated this loss. Along tributary reaches on which stream discharge was measured, the magnitude of simu-lated losses for Little Killbuck Creek and Clear Creek (1.0 and $1.3 \mathrm{ft}^{3} / \mathrm{s}$ ) differed considerably from the measurement-derived losses $\left(1.4\right.$ and $\left.0.5 \mathrm{ft}^{3} / \mathrm{s}\right)$. This discrepancy between simulated and measured losses may be attributed to several factors, including (1) errors in the magnitude and spatial distribution of hydraulic properties assigned to the streambed and aquifer materials in the vicinity of the streams, (2) errors in the stream-discharge measurements used to derive the magnitude of the stream loss, and (or) (3) conditions during fall 1984 differing significantly from conditions prevailing on the dates of streamflow measurement (9 September 1985, and 14 August 1986). Significant fluctuations in temperature and content of deuterium and oxygen-18 isotopes in water from streambed piezometers confirm that streamwater infiltrates the streambed into the shallow drift beneath Killbuck Creek. Comparison of isotope content and chloride concentrations in water from production wells, observation wells, and streams suggests that streamwater infiltrating into the shallow drift does not appear as streamwater in the observation wells within days or weeks after infiltration. Instead, the isotopic and chemical data indicate that the streamwater must be diluted and mixed with ground water and dispersed within the drift. As a result, streamwater is chemically and isotopically unrecognizable as streamwater at the production wells. The time estimated for infiltrating streamwater to reach the shallow ground-water system beneath the stream is likely 2 months or more.

A pattern of progressive increases in the sodium and chloride concentrations of ground water towards the eastem edge of the north well field indicates that lateral or upward flow from the sandstone and shale bedrock is occurring and is acting, in part, as a source of sodium and chloride. Other potential sources of the sodium and chloride exist near the north well field; however, the bedrock adjacent to and beneath the valley is the most likely source on the basis of available data. Chemical and isotopic mixing models indicate that bedrockderived sodium chloride-type water may comprise between 25 and 40 percent of the ground water pumped by production wells located in the central and eastem parts of the north well field. At 25 percent of the $2 \mathrm{Mgal} / \mathrm{d}$, this amounts to about $0.75 \mathrm{ft}^{3} / \mathrm{s}$ at the north well field. Total lateral subsurface flow from the uplands to the valley amounts to $2.83 \mathrm{ft}^{3} / \mathrm{s}$ from the simulations and includes contributions over the entire stratified drift/bedrock interface. The estimate from chemical mixing represents a part of the total flow from bedrock to the stratified drift and is consistent with the simulation.

Areal recharge was simulated by a newly developed method termed the Variable-Recharge procedure. In this method, a specified quantity of water available for recharge is applied to each of the topmost active-model nodes. Depending on the relation of water levels to land-surface elevation, water may enter the ground-water system or may be totally or partially rejected. Water that infiltrates the system may, in turn, seep outward from a node in which the water level is at land surface. This occurs if the net flow to the node from adjacent nodes is positive. The summation of rejected recharge and outward seepage in the uplands represents runoff which is available to recharge the valley in the form of unchanneled recharge to valley nodes adjacent to the valley wall or as channeled recharge by way of losses from tributary streams that flow onto the valley floor.

Lateral subsurface flow from upland sources to the valley was quantified as part of total recharge from upland sources in the steady-state sinulation. The water available for recharge to the uplands was calculated at $3.43 \times 10^{-8} \mathrm{ft} / \mathrm{s}$, or $10.45 \mathrm{ft}^{3} / \mathrm{s}$ over the 
entire upland area in the active model. The quantity of simulated runoff, composed of rejected recharge and outward seepage, was $7.62 \mathrm{ft}^{3} / \mathrm{s}$; thus, $2.83 \mathrm{ft}^{3} \%$ s (or, equivalently, 0.79 in.) was the simulated net recharge to the uplands. This net recharge equals the total lateral subsurface ground-water flow from the upland to the valley. Of the $7.62 \mathrm{ft}^{3} / \mathrm{s}$ of surface runoff, $7.09 \mathrm{ft}^{3} / \mathrm{s}$ was applied to the valley in the form of $3.20 \mathrm{ft}^{3} / \mathrm{s}$ of available unchanneled runoff and $3.89 \mathrm{ft}^{3} / \mathrm{s}$ of available channeled runoff. The remaining runoff of $0.53 \mathrm{ft}^{3} / \mathrm{s}$ was assumed to be unavailable to the valley. The available channeled runoff was applied as streamflow in the upstream nodes of six tributary streams flowing from the western uplands. Because of relatively low values of simulated streambed conductance, there was only $0.17 \mathrm{ft}^{3} / \mathrm{s}$ of recharge to the valley from these streams, whereas the unchanneled runoff from the upland contributed $1.74 \mathrm{ft}^{3} / \mathrm{s}$ of recharge to the valley. Overall, the contributions to the valley from the water available for recharge applied to the uplands consisted of lateral flow to the valley plus channeled and unchanneled runoff and amounted to $4.74 \mathrm{ft}^{3} / \mathrm{s}$, or about 38 percent of the total recharge $\left(12.5 \mathrm{ft}^{3} / \mathrm{s}\right)$ to the Killbuck Creek valley stratified drift. If recharge of $2.99 \mathrm{ft}^{3} / \mathrm{s}$ from Little Killbuck, Clear, and Apple Creeks watershed, by way of stream losses within the valley and $0.17 \mathrm{ft}^{3} / \mathrm{s}$ underflow is included, the total contribution of the uplands $\left(7.9 \mathrm{ft}^{3} / \mathrm{s}\right)$ represents about 63 percent of the flow to the stratified drift. Despite the relatively low horizontal hydraulic conductivity (transmissivity) of the uplands, the lateral flow was a significant proportion of the total flow to the valley. In particular, the $2.83 \mathrm{ft}^{3} / \mathrm{s}$ of simulated lateral flow from the uplands represents about 23 percent of the flow to the stratified drift.

Areal recharge to the Killbuck Creek valley from precipitation on the valley floor is a significant part of the simulated recharge to the stratified drift. Recharge is seldom rejected. Areas comprising 97.5 percent of the valley floor where the water table was below land surface received $2.92 \mathrm{ft}^{3} / \mathrm{s}$ ( 2.87 in.) of direct recharge from precipitation falling on the valley floor. Land uses on the valley floor involve transportation, handling, and storage of materials that are potential contaminants of ground water if accidental or other spills or leaks occur. Precipitation falling on the valley floor could mix with or otherwise mobilize spills or leaks of contaminants. Contaminants can, thus, reach the aquifer via surface recharge on the valley floor.

The areal distribution of simulated recharge was reviewed to determine if localized "windows" of large hydraulic conductivity in the silt and clay cap of the valley fill (layer 1) contributed a large part of the total recharge to the underlying stratified drift. The total simulated flow from layer I to layer 2 north of the divide was $7 \mathrm{ft}^{3} / \mathrm{s}, 72$ percent of which $\left(5.1 \mathrm{ft}^{3} / \mathrm{s}\right)$ was the summation of relatively small flows through a large number of nodes. The remaining $1.9 \mathrm{ft}^{3} / \mathrm{s}$ occurred primarily through a few nodes located beneath Clear Creek with a lesser amount from a few nodes beneath Little Killbuck Creek. The total simulated flow from layer 1 to layer 2 south of the divide was about $1.9 \mathrm{ft}^{3} / \mathrm{s}$, 90 percent of which was the accumulation of many small flows. Thus, except near Clear and Little Killbuck Creeks, the simulated vertical recharge to the buried sand and gravel deposits was in the form of small-magnitude diffuse flow as opposed to large-magnitude flow through local regions of high hydraulic conductivity. This mechanism of recharge is supported by the relatively uniform isotopic signature of the ground water in the stratified-drift aquifer.

The implications of this mechanism of recharge for potential contamination of the aquifer are (1) waters from Clear and Little Killbuck Creeks, if contaminated by an accidental or other type of spill or leak, could enter the aquifer system relatively quickly and potentially affect water quality at the north well field; (2) areal contributions of recharge water dominated by small-magnitude diffuse flow would provide dilution recharge in the event of a spill or leak of a contaminant at a single point in the valley or the uplands; and (3) rapid infiltration of contaminants through "windows" in the valley floor is not likely on the basis of the simulations of recharge for this study. Additional factors need to be considered in the simulations to predict the direction and rate of flow of contaminants to the well fields. The simulation presented in this report provides a framework for evaluating additional factors affecting ground-water quality. 
Seventy percent of the total recharge to the stratified-drift aquifer is withdrawn at the production wells. The Wooster production wells were pumping water at a rate of approximately $8.5 \mathrm{ft}^{3} / \mathrm{s}$, and all simulated sources of water to the stratified drift provide $12.5 \mathrm{ft}^{3} / \mathrm{s}$ of recharge. All production wells are screened within layer 3 of the conceptual ground-water-flow system.

This evaluation of the sources of water to the stratified-drift aquifer must be qualified because the results are based on a model that conceptually represents a complex natural system. The model was conceptualized and designed by use of the available hydrogeologic and aqueous geochemical information. However, the set of simulated hydraulic conductivities, vertical leakance values, streambed properties, water available for recharge rates, pumping rates, and allocation of upland recharge constitute one particular combination of properties that produced a reasonably good fit with respect to a limited set of known characteristics. This combination of properties is descriptive of the Killbuck Creek buried-valley aquifer system during the fall of 1984 and the end of the rapid snowmelt event in late February 1985. Other combinations of properties could produce similar results. In areas in which geologic and geophysical (electrical resistivity) information was available, the model properties are probably a good approximation of the hydrogeologic system. In areas where no information was available, such as along the valley walls, the northern part of the valley, and the region between the north and south well field, the assigned properties are strictly the result of the modelcalibration process and, as such, are less reliable. Nevertheless, the model developed herein provides useful information concerning the sources of water in the Killbuck Creek valley and demonstrates that the stratified-drift aquifer is vulnerable to surface or subsurface spills of contaminants in the valley or the adjacent uplands. The importance of upland sources of water as recharge to the stratified drift is especially significant in delineation of contributing areas and other considerations relating to wellhead protection. 


\section{REFERENCES CITED}

Bennett, G.D., Mundorff, M.J., and Hussain, S.A., 1968, Electric-analog studies of brine coning beneath fresh-water wells in the Punjab region, West Pakistan: U.S. Geological Survey Water-Supply Paper 1608-J, 1 pl., 31 p.

Breen, K.J, 1988, Geochemistry of the stratified-drift aquifer in the Killbuck Creek valley west of Wooster, Ohio, in Randall, A.D.., and Johnson, A.I., eds., Regional Aquifer Systems of the United States, Northeast Glacial Aquifers: American Water Resources Association, Monograph Series, no. 11, p. 105-132.

Claassen, H.C., 1982, Guidelines and techniques for obtaining water samples that accurately represent the water chemistry of an aquifer: U.S. Geological Survey Open-File Report 82-1024, 49 p.

Conrey, G.W., 1921, Geology of Wayne County: Ohio Geological Survey Bulletin 24, 155 p.

Crowell, Katie, 1979, Ground-water resources of Wayne County: Ohio Department of Natural Resources, Division of Water, 1 pl., scale 1:62,500.

Davis, T.M., and Kontis, A.L., 1970, Spline interpolation algorithms for track-type survey data with application to the computation of mean gravity anomalies: U.S. Naval Oceanographic Office Technical Report 226, Bay St. Louis, Mo., 50 p.

Dunne, T. and Black, R.D., 1970, Partial area contributions to storm runoff in a small New England watershed: Water Resources Research, v. 6, no. 5 , p. $1296-1311$.

Dysart, J.E., 1988, Use of Oxygen-18 and deuterium mass-balance analysis to evaluate induced recharge to stratified-drift aquifers, in Randall, A.D., and Johnson, A.I., eds., Regional Aquifer Systems of the United States, Northeast Glacial Aquifers: American Water Resources Association, Monograph Series, no. 11, p. 133-154.

Fenneman, N.M. 1938, Physiography of the eastern United States: New York, McGraw-Hill, 691 p.
Freeze, R.A., and Cherry, T.A., 1979, Groundivater: Englewood Cliffs, N.J., Prentice Hall, 604 p.

Handman, E.H., 1986, Delineating recharge areas for stratified drift aquifers in Connecticut with geologic and hydrologic maps: U.S. Geological Survey Water- Resources Investigations Report 83-4230, $39 \mathrm{p}$.

Heath, R.C., 1983, Basic ground-water hydrology: U.S. Geological Survey Water-Supply Paper 2220, 84 p.

Jones, H.P., Henry, T.B., and Williams, L.G., 1958, Water improvements report for Wooster, Ohio: Toledo, Ohio, Jones, Henry, and Williams, Engineers, 201 p.

Kontis, A.L., and Mandle, R.J., 1980, Data-base system for northern Midwest regional aquifer system analysis: U.S. Geological Survey Water-Resources Investigations Report 80-104, 23 p.

Lapham, W.W., 1989, Use of temperature profiles beneath streams to determine rates of vertical ground-water flow and vertical hydraulic conductivity: U.S. Geological Survey WaterSupply Paper 2337, 35 p.

Lee, D.R., and Cherry, J.A., 1978, A field exercise on ground water flow using seepage meters and minipiezometers: Journal of Geological Education, v. 27, p. 6-10.

Lyford, F.P., and Cohen, A.J., 1988, Estimation of water available for recharge to sand and gravel aquifers in the glaciated Northeastern United States, in Randall, A.D., and Johnson, A.I., eds., Regional Aquifer Systems of the United States, Northeast Glacial Aquifers: American Water Resources Association, Monograph Series, no. 11, p. 37-61.

Mayhew, G.H., 1985, Contamination investigation of the south wellfield for the city of Wooster, Olio: Massillon, Ohio, Ohio Drilling Company, 17 p.

McDonald, M.G., and Harbaugh, A.W., 1988, A modular three-dimensional finite difference groundwater flow model: U.S. Geological Survey Techniques of Water-Resources Investigations, book C, chap. A1, $586 \mathrm{p}$. 
McNeill, J.D., 1980, Electromagnetic terrain conductivity measurement at low induction numbers: Mississauga, Ontario, Geometrics Limited, Technical Note TN-6, $15 \mathrm{p}$.

Meinzer, O.E., 1923, Occurrence of ground water in the United States: U.S. Geological Survey WaterSupply Paper 489, 321 p.

Miller, L.E., 1976, Aquifer performance evaluation and ground-water production potential of the city of Wooster, Ohio: Toledo, Ohio, Jones and Henry Engineers, Lid., $15 \mathrm{p}$.

Miller, L.M., and Associates, 1981, Pumping test analysis of the south wellfield-well no. S-2, Wooster, Ohio: Toledo, Ohio, Jones and Henry Engineers, Ltd., 15 p.

Morrissey, J.D., Randall, A.D., and Williams, J.H., 1988, Upland runoff as a major source of recharge to stratified drift in the glaciated Northeast, in Randall, A.D., and Johnson, A.I., eds., Regional Aquifer Systems of the United States, Northeast Glacial Aquifers: American Water Resources Association, Monograph Series, no. 11, p. 17-36.

Multer, H.G., 1967, Bedrock geology of Wayne County, Ohio: Ohio Geological Survey, Report of Investigations $61,1 \mathrm{pl}$.

Potter, S.T., and Gburek, W.J., 1987, Seepage face simulation using PLASM: Ground Water, v. 25, no. 6, p. $722-732$.

Prudic, D.E., 1989, Documentation of a computer program to simulate streain-aquifer relations using a modular, finite difference, ground-water flow model: U.S. Geological Survey Open-File Report 88-729, 113 p.

Randall, A.D., 1979, Ground water in Dale Valley, New York: U.S. Geological Survey Water-Resources Investigations Report 78-120, 92 p.

Reilly, T.E., Frimpter, M.H., LeBlanc, D.R., and Goodman, A.S., 1987, Analysis of steady-state saltwater upconing with application at Truro well field, Cape Cod, Massachusetts: Ground Water, v. 25, no. 2 , p. 194-206.
Sedam, A.C., and Stein, R.B., 1970, Saline ground-water resources of Ohio: U.S. Geological Survey Hydrologic Investigations Atlas HA-366, 2 pls., scale 1:500,000.

Shedlock, R.J., 1980, Saline water at the base of the glacial-outwash aquifer near Vincennes, Knox County, Indiana: U.S. Geological Survey WaterResources Investigations Report 80-65, 55 p.

Shindel, H.L., Klingler, J.H., Mangus, J.P., and Trimble, L.E., 1985, Water-resources data-Ohio, volume 2: U.S. Geological Survey WaterData Report OH-85-2, p. 162-182.

--- 1986, Water-resources data--Ohio, volume 2: U.S Geological Survey Water-Data Report OH-86-2, p. 274-280.

---- 1987, Water-resources data--Ohio, volume 2: U.S. Geological Survey Water-Data Report OH-87-2, 342 p

Springer, A.E., 1987, A hydrogeologic evaluation of ground water resources of Wooster, Ohio: Wooster, Ohio, an unpublished senior independent-study thesis, The College of Wooster, $78 \mathrm{p}$.

---- 1990, An evaluation of wellfield-protection area delineation methods as applied to municipal wells in the stratified drift aquifer at Wooster, Ohio: Unpublished M.S. thesis, Department of Geology and Mineralogy, The Ohio State University, 167 p.

Springer, A.E., and Bair, E.S., 1990, The effectiveness of semianalytical methods for delineating wellfield protection areas in stratified-drift buried-valley aquifers: Ground Water Management, v. 1, p. 413-429.

Springer, A.E., and Bair, E.S., 1992, Comparison of methods used to delineate capture zones of wells: 2 . Stratified-drift buried-valley aquifer: Ground Water, v. 30, no. 6, p. 908-917.

Todd, D.K., ed., 1970, The Water Encyclopedia: Port Washington, N.Y., Water Information Center, $559 \mathrm{p}$. 
White, G.W., 1967, Glacial geology of Wayne County, Ohio: State of Ohio Department of Natural Resources, Division of Geological Survey Report of Investigation no. $62,1 \mathrm{pl} ., 39 \mathrm{p}$.

Wood, W.W., 1976, Guidelines for collection and field analysis of ground-water samples for selected unslable conslituents: U.S. Geological Survey Techniques of Water-Resources Investigations, book 1, chap. D2, 24 p. 


\section{SUPPLEMENTAL DATA}

Table 6. Records of ground-water levels in the vicinity of Killbuck Creek valley, near Wooster, Ohio

Table 19. Water-quality records for ground-water and surface-water samples, Killbuck Creek valley near Wooster, Ohio 
Table 6. Records of ground-water levels in the vicinity of Killbuck Creek valley, near Wooster, Ohio

Local Number - WN, Wayne County prefix; D, deep observation well-screened greater than 50 feet below land surface; $S$, shallow observation well--screened in upper gravels, less than 35 feet below land surface; $P$, deep production well- - screened greater than 50 feet below land surface (except $P 2$ and $\mathrm{P31}$-screened less than $50 \mathrm{ft}$ below land surface); C, streambed piezometer installed in Clear Creek; K, streambed piezometer installed in Killbuck Creek.

Station number - 15-digit unique identifier based on site latitude (first six digits), longitude (digits seven through thirteen), and a 2-digit sequencenumber suffix.

Datum - Altitude, in feet above sea level, of the land surface at the well.

Water level - The depth to water in the well, in feet below the datum. A negative value indicates that the water level is above the datum. Intermittent measurements of static water level by U.S. Geological Survey personnel using chalked steel tape; measurements with asterisk are by City of Wooster personnel; $P$, indicates measurement during pumping, not a static level; $A$, indicates measurement by air-line; $T$, measurement by electric tape. DRY indicates a water level beneath the bottom of the well. HIGHEST refers to the water level (of those listed) that was highest in the well, that is, closest to the land surface. LOWEST refers to the water level (of those listed) that was furthest from the land surface.

\begin{tabular}{llllll}
\hline & Water & Water & Water \\
Date & level & Date & levei & Date & level \\
\hline
\end{tabular}

Stratlfied-drlft aquifer

Local Number: WN-P2

JUL 18,1984

AUG 08, 1984

28.67

AUG 30, 1984

OCT 25, 1984

NOV 07,1984

NOV 28, 1984

DEC 12, 1984

HIGHEST
LOWEST

Local Number: WN.P3

OCT 19, $1984 \quad 38.83$

NOV 16, $1984 \quad 38.67 *$

DEC 14, $1984 \quad 39.75^{*}$

JAN 11, 1985 42.92*

Local Number: WN-P4

OCT 19, 1984

$47.17^{*}$

NOV 16, 1984

$47.25 *$

$48.50^{*}$

JAN 11, 1985

$47.67 *$

Local Number: WN-P5

OCT 19, 1984 34.58*

NOV $16,1984 \quad 35.08^{*}$

DEC 14, $1984 \quad 35.50^{*}$

JAN 11, $1985 \quad 34: 50^{*}$

Local Number: WN-P6

OCT 19, $1984 \quad 35.58 *$

NOV 16, $1984 \quad 35.82 *$

DEC 14, $1984 \quad 36.50^{*}$

JAN 11, $1985 \quad 35.42 *$

Local Number: WN.P7

OCT 19, $1984 \quad 36.00^{*}$

NOV 16, $1984 \quad 36.50^{*}$

DEC 14, $1984 \quad 37.00^{*}$

JAN 11, $1985 \quad 35.83^{*}$
Station Number: 404801081583700

JAN 03, $1985 \quad 31.01$

JAN 17, $1985 \quad 31.78$

JAN 30, $1985 \quad 32.26$

MAR 05, $1985 \quad 25.47$

MAR 07, $1985 \quad 26.16$

MAR 19, $1985 \quad 26.02$

APR 17, 1985

APR 10, 1986

JAN 30, 1985

Station Number: $\mathbf{4 0 4 8 0 2 0 8 1 5 8 3 4 0 0}$

FEB 15, 1985 40.33*

MAR 15, $1985 \quad 37.50^{*}$

JUN 28, 1985 35.58*

JUL 19, $1985 \quad 31.33^{*}$

Station Number: 404801081583300

FEB 15, $1985 \quad 49.92 *$

MAR 15, $1985 \quad 43.00^{*}$

JUN 28, $1985 \quad 46.67 *$

JUL 19, 1985 . $47.50^{*}$

Station Number: $\mathbf{4 0 4 8 0 0 0 8 1 5 8 3 1 0 0}$

FEB 15, 1985 38.75*

MAR 15, $1985 \quad 28.50^{*}$

JUN 28, $1985 \quad 32.00^{*}$

JUL 19, $1985 \quad 32.75 *$

Station Number: $\mathbf{4 0 4 7 5 9 0 8 1 5 8 3 0 0 0}$

FEB 15, 1985 37.33*

MAR 15, $1985 \quad 33.17^{*}$

JUN 28, $1985 \quad 32.50^{*}$

JUL 19, $1985 \quad 33.17 *$

Station Number: 404758081582900

FEB 15, $1985 \quad 37.66^{*}$

MAR 15, $1985 \quad 27.00^{*}$

JUN 28, 1985 30.67*

JUL 19, $1985 \quad 32.92 *$
JUN 05,1985

JUN 27, 1985

AUG 28, 1985

SEP 23, 1985

APR 10, 1986

AUG 16, 1985

SEP 13, 1985

AUG 16, 1985

SEP 13, 1985

Datum: $858.9 \mathrm{ft}$

48.75*

$50.08 *$

AUG 16, 1985

SEP 13, 1985

Datum: $858.5 \mathrm{ft}$

$34.25 *$

$35.33^{*}$

AUG 16, 1985

Datum: $858.4 \mathrm{ft}$

SEP 13, 1985

$34.58 *$

$35.67 *$
Datum: $858.3 \mathrm{ft}$

AUG 16, $1985 \quad 34.75^{*}$

SEP 13, $1985 \quad 36.25 *$ 
Table 6. Records of ground-water levels in the vicinity of Killbuck Creek valley, near Wooster, Ohio-Continued

\begin{tabular}{llllll}
\hline Date & $\begin{array}{l}\text { Water } \\
\text { level }\end{array}$ & Date & $\begin{array}{l}\text { Water } \\
\text { level }\end{array}$ & Date & $\begin{array}{l}\text { Water } \\
\text { level }\end{array}$ \\
\hline
\end{tabular}

Stratifled-drift aquifer-Continued

Local Number: WN.p8

OCT $19,1984 \quad 42.58 *$

NOV $16,1984 \quad 42.75 *$

DEC 14, $1984 \quad 44.50^{*}$

JAN 11,1985

Local Number: WN-P31

APR 14, $1986 \quad 17.54$

MAY 30, $1986 \quad 20.62$

HIGHEST $\quad 17.54$

LOWEST 22.61

Local Number: WN-D1

JUL 19, 1984

JUL 26, $1984 \quad 25.08$

AUG 08, 1984

AUG 30, $1984 \quad 26.42$

SEP 04, $1984 \quad 26.04$

OCT $15,1984 \quad 27.09$

OCT 25, 1984

NOV 07, $1984 \quad 26.95$

HIGHEST $\quad 21.05$

LOWEST $\quad 27.50$

Local Number: WN-D2

JUL 26, 1984

29.73

AUG 08, 1984

32.20

31.98

SEP 04, $1984 \quad 32.99$

SEP 10, $1984 \quad 33.30$

SEP 12, $1984 \quad 33.86$

OCT 15, $1984 \quad 34.25$

OCT 25, 1984

NOV 05, $1984 \quad 34.61$

NOV 09, $1984 \quad 34.67$

NOV 28, 1984

HIGHEST $\quad 27.38$

LOWEST $\quad 36.84$

Local Number: WN-S3

JUL 19, 1984

JUL 26, 1984

30.77

32.29

AUG 08, 1984

32.40

SEP 04, 1984

SEP 10, 1984

OCT 15,1984

OCT 25,1984

NOV 05, 1984
DRY

DRY
Station Number: $\mathbf{4 0 4 7 5 8 0 8 1 5 8 3 4 0 0}$

FEB 15, $1985 \quad 33.92 *$

MAR 15, $1985 \quad 25.50^{*}$

JUN 28, $1985 \quad 39.67^{*}$

JUL 19, $1985 \quad 29.00^{*}$

Station Number: $\mathbf{4 0 4 7 4 2 0 8 1 5 8 3 3 0 0}$

JUL 08, $1986 \quad 20.01$

OCT 02, $1986 \quad 22.61$

APR 14, 1986

OCT 02,1986

Station Number: $\mathbf{4 0 4 8 0 1 0 8 1 5 8 3 5 0 0}$

NOV 28, $1984 \quad 26.92$

DEC 12, $1984 \quad 27.40$

JAN 03, $1985 \quad 26.52$

JAN 17, $1985 \quad 26.90$

JAN 30, $1985 \quad 27.40$

MAR 05, $1985 \quad 21.80$

MAR 07, $1985 \quad 22.02$

MAR 19,1985 21.75

APR 10, 1986

OCT 25,1984

Station Number: $\mathbf{4 0 4 8 0 2 0 8 1 5 8 3 1 0 2}$

DEC 12, $1984 \quad 35.30$

JAN 03, $1985 \quad 33.90$

JAN 18, 1985

JAN 30, $1985 \quad 35.31$

FEB 22, $1985 \quad 36.84$

FEB 26, $1985 \quad 29.45$

MAR 05, $1985 \quad 27.38$

MAR 07, $1985 \quad 28.25$

MAR 20, $1985 \quad 28.01$

APR 17, $1985 \quad 27.65$

APR 30, $1985 \quad 28.34$

MAR 05, 1985

FEB 22, 1985

Station Number: $\mathbf{4 0 4 8 0 2 0 8 1 5 8 3 1 0 3}$

JAN 03, 1985 DRY

JAN 18, 1985 DRY

JAN 30, 1985

DRY

FEB 22, 1985 DRY

FEB 26, $1985 \quad 24.70$

MAR 05, $1985 \quad 27.42$

MAR 07, $1985 \quad 28.08$

MAR 20, $1985 \quad 26.88$
AUG 16, 1985

SEP 13, 1985

Datum: $856.5 \mathrm{ft}$

40.58*

$32.25 *$

Datum: 852.6 ft

APR 17, 1985

JUN 05, 1985

JUN 27, 1985

AUG 28, 1985

SEP 23, 1985

APR 10, 1986

Datum: $856.4 \mathrm{ft}$

21.10

23.11

24.00

26.46

27.40

21.05
MAY 30,1985

JUN 05, 1985

JUN 27, 1985

JUL 28, 1985

AUG 28, 1985

SEP 23, 1985

SEP 30, 1985

APR 10, 1986

MAY 30,1986

JUL 10, 1986

OCT 02, 1986

JUN 05, 1985

JUN 27, 1985

JUL 28, 1985

AUG 15, 1985

AUG 28, 1985

SEP 23, 1985

APR 10, 1986

MAY 30, 1986
Datum: $858.6 \mathrm{ft}$

29.64

29.76

31.07

31.22

34.12

35.18

35.31

27.82

30.01

28.28

33.07 
Table 6. Records of ground-water levels in the vicinity of Killbuck Creek valley, near Wooster, Ohio-Continued

\begin{tabular}{|c|c|c|c|c|c|}
\hline Date & $\begin{array}{l}\text { Water } \\
\text { level }\end{array}$ & Date & $\begin{array}{l}\text { Water } \\
\text { level }\end{array}$ & Date & $\begin{array}{l}\text { Water } \\
\text { level }\end{array}$ \\
\hline \multicolumn{6}{|c|}{ Stratilied-drift aquifer-Continned } \\
\hline \multicolumn{2}{|c|}{ Local Nnmber: WN-S3_Continned } & \multicolumn{3}{|c|}{ Statlon Nnmber: 404802081583103} & \multirow{4}{*}{$\begin{array}{l}\text { Datum: } 858.7 n \\
28.24\end{array}$} \\
\hline NOV 09, 1984 & DRY & APR 17,1985 & 27.65 & JUL 10, 1986 & \\
\hline NOV 28,1984 & DRY & APR 30, 1985 & 28.05 & & \\
\hline DEC 12, 1984 & DRY & MAY 30, 1985 & 29.63 & & \\
\hline HIGHEST & \multirow{2}{*}{$\begin{array}{r}24.70 \\
\text { WELL DRY }\end{array}$} & \multirow{2}{*}{\multicolumn{3}{|c|}{ FEB 26, 1985}} & \\
\hline LOWEST & & & & & \\
\hline \multicolumn{2}{|c|}{ Local Nnmber: WN-D4 } & \multicolumn{3}{|c|}{ Station Nnmber: $\mathbf{4 0 4 8 0 0 0 8 1 5 8 4 5 0 0}$} & Datum: $855.9 n$ \\
\hline JUL 19,1984 & 20.99 & JAN 03, 1985 & 23.20 & MAY 03, 1985 & 19.31 \\
\hline JUL 26, 1984 & 21.67 & JAN 16,1985 & 23.35 & MAY 30,1985 & 20.06 \\
\hline AUG 08, 1984 & 22.07 & JAN 17,1985 & 23.43 & JUN 05, 1985 & 19.86 \\
\hline AUG 30, 1984 & 23.01 & JAN 30, 1985 & 23.62 & JUN 27, 1985 & 20.57 \\
\hline SEP 04, 1984 & 22.90 & FEB 25, 1985 & 21.77 & JUL 16, 1985 & 21.37 \\
\hline SEP 12, 1984 & 23.23 & MAR 05, 1985 & 18.97 & AUG 13, 1985 & 22.37 \\
\hline OCT 15,1984 & 23.97 & MAR 07, 1985 & 18.81 & AUG 28, 1985 & 23.05 \\
\hline OCT 25,1984 & 24.19 & MAR 20, 1985 & 18.76 & SEP 23, 1985 & 24.05 \\
\hline NOV 09, 1984 & 24.10 & APR 11,1985 & 17.69 & APR 10, 1986 & 17.67 \\
\hline NOV 26, 1984 & 23.43 & APR 17, 1985 & 18.03 & APR 21, 1986 & 18.58 \\
\hline DEC 12, 1984 & 23.94 & APR 29, 1985 & 18.88 & & \\
\hline HIGHEST & 17.67 & APR 10, 1986 & & & \\
\hline LOWEST & 24.19 & OCT 25,1984 & & & \\
\hline \multicolumn{2}{|c|}{ Local Nnmber: WN-S5 } & \multicolumn{3}{|c|}{ Station Nnmber: 404800081584501} & Datum: $855.4 \mathrm{n}$ \\
\hline JUL 19, 1984 & 20.69 & JAN 03, 1985 & 22.98 & MAY 30,1985 & 19.89 \\
\hline JUL 26, 1984 & 21.31 & JAN 16,1985 & 23.03 & JUN 05, 1985 & 19.68 \\
\hline AUG 08, 1984 & 21.75 & JAN 30, 1985 & 23.54 & JUN 27,1985 & 20.37 \\
\hline AUG 30, 1984 & 21.20 & FEB 25, 1985 & 21.82 & JUL 16, 1985 & 21.15 \\
\hline SEP 04, 1984 & 22.42 & MAR 05, 1985 & 18.71 & AUG 13, 1985 & 22.49 \\
\hline SEP 12, 1984 & 22.93 & MAR 07, 1985 & 18.62 & AUG 28, 1985 & 22.87 \\
\hline OCT 15,1984 & 20.82 & MAR 20,1985 & 18.55 & SEP 23, 1985 & 23.85 \\
\hline OCT 25,1984 & 23.94 & APR 11, 1985 & 17.40 & APR 10, 1986 & 17.65 \\
\hline NOV 09,1984 & 23.74 & APR 17, 1985 & 17.79 & APR 21, 1986 & 18.52 \\
\hline NOV 26,1984 & 23.20 & APR 29, 1985 & 18.55 & & \\
\hline DEC 12, 1984 & 23.65 & MAY 03, 1985 & 18.92 & & \\
\hline HIGHEST & 17.40 & APR 11, 1985 & & & \\
\hline LOWEST & 23.94 & OCT 25,1984 & & & \\
\hline \multicolumn{2}{|c|}{ Local Number: WN-D6 } & \multicolumn{3}{|c|}{ Station Nnmber: 404839081590900} & Datnm: $856.6 n$ \\
\hline JUL 18, 1984 & 4.63 & JAN 03, 1985 & 3.98 & JUN 06, 1985 & 3.99 \\
\hline JUL 26, 1984 & 4.84 & JAN 15,1985 & 5.20 & JUN 20, 1985 & 4.06 \\
\hline AUG 08, 1984 & 4.52 & JAN 30, 1985 & 5.44 & JUN 27, 1985 & 4.40 \\
\hline AUG 30, 1984 & 5.04 & FEB 13,1985 & 5.67 & JUL 16,1985 & 4.73 \\
\hline SEP 04, 1984 & 5.37 & FEB 21,1985 & 5.73 & AUG 28, 1985 & 5.13 \\
\hline SEP 10, 1984 & 5.47 & FEB 22, 1985 & 5.49 & SEP 23, 1985 & 5.94 \\
\hline OCT 15,1984 & 5.87 & FEB 26, 1985 & 1.73 & SEP 30,1985 & 5.94 \\
\hline OCT 25,1984 & 5.78 & MAR 05, 1985 & 3.56 & APR 10, 1986 & 3.71 \\
\hline NOV 07, 1984 & 4.61 & MAR 07, 1985 & 3.66 & JUL 08, 1986 & 3.96 \\
\hline
\end{tabular}


Table 6. Records of ground-water levels in the vicinity of Killbuck Creek valley, near Wooster, Ohio-Continued

\begin{tabular}{llllll}
\hline Date & $\begin{array}{l}\text { Water } \\
\text { level }\end{array}$ & Date & $\begin{array}{l}\text { Water } \\
\text { level }\end{array}$ & Date & $\begin{array}{l}\text { Water } \\
\text { level }\end{array}$ \\
\hline
\end{tabular}

Stratified-drift aquifer-Continned

$\begin{array}{lc}\text { Local Number: WN-D6-Continned } \\ \text { NOV 26, } 1984 & 5.44 \\ \text { DEC 12, } 1984 & 5.11\end{array}$

HIGHEST $\quad 1.73$

LOWEST $\quad 5.94$

Local Nnmber: WN-S6A

MAY 03, $1985 \quad 3.90$

JUN 06, 1985

JUL 16, 1985

AUG 28, 1985

HIGHEST $\quad 2.46$

LOWEST $\quad 5.13$

Local Number: WN-S7

JUL 26, 1984

17.84

AUG 08, 1984

18.53

19.40

AUG 30, 1984

20.22

SEP 04, 1984

20.64

SEP 10, 1984

20.69

OCT 15,1984

DRY

DRY

OCT 25, 1984

NOV 07, 1984

DRY

HIGHEST

15.62

LOWEST

20.97

Local Nnmber: WN-S8

JUL 18, 1984

22.07

JUL 26, 1984

AUG 08, $1984 \quad 23.39$

AUG 30, $1984 \quad 24.38$

SEP 04, 1984

SEP 12, $1984 \quad 24.76$

OCT $15,1984 \quad 26.72$

OCT 25, 1984

NOV 05, $1984 \quad 26.50$

NOV 07, $1984 \quad 26.49$

HIGHEST $\quad 19.82$

LOWEST $\quad 27.67$
Station Number: $\mathbf{4 0 4 8 3 9 0 8 1 5 9 0 9 0 0}$

MAR 21, $1985 \quad 4.07$

APR 17, $1985 \quad 3.71$

MAY 01, 1985

4.23

FEB 26, 1985

SEP 23, 1985, SEP 30, 1985

Station Nnmber: $\mathbf{4 0 4 8 3 9 0 8 1 5 9 0 9 0 1}$

SEP 23, 1985

5.13

SEP 301985

5.11

APR 10, 1986

2.55

JUL 08, 1986

2.75

JUN 06, 1985

SEP 23, 1985

Station Number: 404807081582000

NOV 26, 1984

DRY

DEC 12, 1984

JAN 03, 1985

JAN 16, 1985

FEB 26, 1985

MAR 05, 1985

MAR 07, 1985

MAR 20, 1985

DRY

DRY

DRY

DRY

20.08

20.34

18.69

APR 17, 1985

16.58

APR 10, 1986

AUG 28, 1985

Station Number: 404805081582600

NOV 08, 1984

26.59

NOV 26, 1984

26.28

DEC 12, 1984

26.59

JAN 03, 1985

26.42

26.36

JAN 15, 1985

26.65

FEB 22, 1985

FEB 26, 1985

MAR 05, 1985

MAR 07, 1985

27.67

25.06

23.79

23.14
AUG 06, 1986

AUG 14, 1986

DEC 21, 1988

AUG 06, 1986

AUG 14, 1986

DEC 02, 1988

MAY 01, 1985

JUN 06, 1985

JUN 27, 1985

AUG 28, 1985

SEP 23, 1985

APR 10, 1986

DEC 20, 1988

MAR 19,1985

APR 17, 1985

APR 30, 1985

JUN 05, 1985

JUN 27, 1985

JUL 16, 1985

AUG 28, 1985

SEP 23, 1985

APR 10, 1986

AUG 14, 1986
Datum: $856.6 \mathrm{ft}$

4.45

4.60

5.52

Datnm: $856.7 \mathrm{n}$

3.58

3.82

4.25

Datum: $856.5 \mathrm{ft}$

16.87

17.82

18.24

20.97

DRY

15.62

DRY

APR 10, 1986

FEB 22, 1985

Datum: $856.6 \mathrm{ft}$

21.64

20.42

20.81

21.99

22.36

23.05

25.13

26.61

19.82

21.89 
Table 6. Records of ground-water levels in the vicinity of Killbuck Creek valley, near Wooster, Ohio-Continued

\begin{tabular}{llllll}
\hline Date & Water & Water & Water \\
level & Date & level & Date & level \\
\hline
\end{tabular}

Stratified-drift aquffer-Coutiuned

Local Number: WN-D9

JUL 19, 1984

JUL 26, 1984

AUG 08, 1984

AUG 30, 1984

SEP 04, 1984

SEP 12, 1984

OCT 15,1984

OCT 25, 1984

NOV 05, 1984

NOV 07, 1984

HIGHEST

LOWEST

33.98

Local Number: WN.D10

JUL 19, 1984

JUL 26, $1984 \quad 29.75$

AUG 08, $1984 \quad 29.82$

AUG 30, $1984 \quad 31.42$

SEP 04, $1984 \quad 30.70$

SEP 10, $1984 \quad 30.29$

OCT $15,1984 \quad 32.00$

OCT 25, $1984 \quad 32.66$

NOV 09, $1984 \quad 32.59$

NOV 27, 1984

HIGHEST $\quad 24.42$

LOWEST $\quad 33.96$

Local Number: WN-S11

JUL 19, 1984

26.73

JUL 26, $1984 \quad 27.63$

AUG 08, $1984 \quad 28.04$

AUG 30, $1984 \quad 29.41$

SEP 04, $1984 \quad 28.93$

SEP 10, $1984 \quad 29.13$

OCT 15, 1984 DRY

OCT 25, 1984 DRY

NOV 09, 1984 DRY

NOV 27, $1984 \quad$ DRY

HIGHEST $\quad 22.65$

LOWEST $\quad 30.56$

Local Number: WN-D12

JUL 19, $1984 \quad 24.56$

JUL 26, 1984

AUG 08, 1984

AUG 30, $1984 \quad 27.05$

SEP 04, $1984 \quad 26.82$
Statjon Number: $\mathbf{4 0 4 8 0 5 0 8 1 5 8 2 6 0 1}$

NOV 08, $1984 \quad 32.10$

NOV 26, $1984 \quad 30.77$

DEC 12, $1984 \quad 32.46$

JAN 03, $1985 \quad 31.19$

JAN 15, $1985 \quad 31.84$

JAN 30, $1985 \quad 32.38$

FEB 22, $1985 \quad 33.98$

FEB 26, $1985 \quad 26.55$

MAR 05, $1985 \quad 25.04$

MAR 07, 1985

25.56

APR 17, 1985

FEB 22, 1985

Station Number: $\mathbf{4 0 4 7 5 2 0 8 1 5 8 3 4 0 0}$

DEC 12, 1984

JAN 03, $1985 \quad 31.67$

JAN 30, 1985

FEB 21, $1985 \quad 33.96$

MAR 05, $1985 \quad 24.42$

MAR 07, $1985 \quad 25.07$

MAR 21, $1985 \quad 25.73$

APR 17, $1985 \quad 25.04$

MAY 02, $1985 \quad 26.23$

JUN 07, $1985 \quad 27.47$

MAR 05, 1985

FEB 21, 1985

Station Number: $\mathbf{4 0 4 7 5 2 0 8 1 5 8 3 4 0 1}$

DEC 12,1984 $\quad 30.56$

JAN 03, $1985 \quad 29.88$

JAN 30, 1985 DRY

FEB 21, 1985 DRY

MAR 05, $1985 \quad 22.65$

MAR 07, $1985 \quad 23.22$

MAR 21, $1985 \quad 24.16$

APR 17, $1985 \quad 23.32$

MAY 02, $1985 \quad 24.55$

JUN 07, 1985

25.82

MAR 05, 1985

DEC 12, 1984

Station Number: $\mathbf{4 0 4 7 4 4 0 8 1 5 8 2 1 0 0}$

NOV 27, $1984 \quad 27.83$

DEC 12, 1984

JAN 03, $1985 \quad 27.35$

JAN 30, $1985 \quad 28.31$

FEB 21, 1985
MAR 19, 1985

APR 17, 1985

APR 30, 1985

JUN 05, 1985

JUN 27, 1985

JUL 17, 1985

AUG 28, 1985

SEP 23, 1985

APR 10, 1986

AUG 14, 1986

JUN 27, 1985

JUL 02, 1985

JUL 28, 1985

AUG 14, 1985

AUG 28, 1985

SEP 23, 1985

APR 10, 1986

MAY 30,1986

JUN 27, 1985

JUL 02, 1985

JUL 28, 1985

AUG 14, 1985

AUG 28, 1985

SEP 23, 1985

APR 10, 1986

APR 21, 1986

MAY 14, 1986

MAY 30, 1986

MAY 02, 1985

JUN 07, 1985

JUN 27, 1985

AUG 28, 1985

SEP 23, 1985
Datum: $856.8 \mathrm{ft}$

25.73

25.03

25.90

27.00

28.25

28.78

31.22

32.34

25.15

27.06

Datum: $857.2 \mathrm{ft}$

28.56

29.17

29.46

31.69

31.75

33.95

25.33

28.10
Datum: $856.7 \mathrm{ft}$

26.65

27.17

28.08

29.64

30.01

DRY

23.25

24.24

25.79

26.47
Datum: $857.2 \mathrm{ft}$

22.41

23.42

24.33

27.55

28.60 
Table 6. Records of ground-water levels in the vicinity of Killbuck Cre日k valley, near Wooster, Ohio-Continued

\begin{tabular}{|c|c|c|c|c|c|}
\hline Date & $\begin{array}{l}\text { Water } \\
\text { level }\end{array}$ & Date & $\begin{array}{l}\text { Water } \\
\text { level }\end{array}$ & Date & $\begin{array}{l}\text { Water } \\
\text { level }\end{array}$ \\
\hline \multicolumn{6}{|c|}{ Stratified-drift aquifer-Continued } \\
\hline \multicolumn{2}{|c|}{ Local Number: WN-D12-Continued } & \multicolumn{3}{|c|}{ Station Number: 404744081582100} & Datum: $857.2 \mathrm{n}$ \\
\hline SEP 10, 1984 & 26.99 & MAR 05, 1985 & 19.86 & APR 10, 1986 & 21.53 \\
\hline OCT 15,1984 & 28.06 & MAR 07, 1985 & 20.44 & APR 14, 1986 & 21.89 \\
\hline OCT 25,1984 & 28.43 & MAR 21, 1985 & 21.15 & MAY 30, 1986 & 24.80 \\
\hline NOV 09,1984 & 28.38 & APR 17,1985 & 21.09 & & \\
\hline HIGHEST & 19.86 & MAR 05, 1985 & & & \\
\hline LOWEST & 29.21 & FEB 21,1985 & & & \\
\hline
\end{tabular}

\section{Stratifled-drift aquifer streambed piezometers}

Local Number: WN-S13

JUL 19, 1984

JUL 26, 1984

AUG 08, 1984

AUG 30, 1984

SEP 04, 1984

OCT 15,1984

OCT 25, 1984

\section{HIGHEST}

LOWEST

Local Number: WN-17

FEB 25, 1985

60. A

HIGHEST

LOWEST

Local Number: WN-C1

JUN 20, 1985

JUL 01, 1985

Local Number: WN-K1

JUN 20, 1985

JUL 01, 1985

DRY

DRY

Local Number: WN-K2

JUN 20, 1985

\section{HIGHEST}

LOWEST

$-.57$

$-.16$

Local Number: WN-K3

JUN 20, 1985

JUN 24, 1985

JUL 01, 1985

2.20
Station Number: $\mathbf{4 0 4 8 0 6 0 8 1 5 9 0 2 0 0}$

NOV 09, $1984 \quad 8.33$

NOV 28, $1984 \quad 7.79$

DEC 13, 1984

JAN 03, $1985 \quad 7.03$

JAN 30, $1985 \quad 7.79$

FEB 26, 1985

MAR 05, 1985

5.93

FEB 26, 1985

OCT 15,1984

Station Number: $\mathbf{4 0 4 7 5 9 0 8 1 5 8 2 1 0 0}$

AUG 28, $1985 \quad 31 . T$

AUG 28, 1985

FEB 25, 1985

Station Number: $\mathbf{4 0 4 8 1 0 0 8 1 5 8 3 4 0 0}$

JUL 17, 1985 DRY

AUG 27, 1985 . DRY

Station Number: $\mathbf{4 0 4 8 0 6 0 8 1 5 8 3 3 0 0}$

AUG 01, 1985 DRY

AUG 27, 1985 DRY

Station Number: $\mathbf{4 0 4 8 3 9 0 8 1 5 8 5 2 0 1}$

JUL 01, $1985 \quad-.16$

JUL 16, 1985

JUL 01, 1985

Station Number: $\mathbf{4 0 4 8 2 5 0 8 1 5 8 4 9 0 1}$

JUL 17, $1985 \quad 1.05$

AUG 27, $1985 \quad 1.60$

SEP 23, $1985 \quad 2.10$

.47 JUN 20, 1985

SEP 30, 1985
MAR 07, 1985

MAR 21, 1985

APR 17, 1985

JUN 27, 1985

AUG 28, 1985

SEP 23, 1985

APR 10, 1986

SEP 23, 1985

SEP 30, 1985

SEP 23, 1985

JUL 16, 1985

Datum: $851.4 \mathrm{ft}$

$-.18$

Datum: $848.4 \mathrm{ft}$

SEP 30, 1985

2.20

6.09

6.17

5.82

6.76

7.92

8.86

6.05

Datum: $860 \mathrm{nt}$

Datum: 850.0 ft

DRY

DRY

DRY
Datum: $\mathbf{8 5 8 . 2} \mathrm{ft}$

Datum: $847.8 \mathrm{ft}$ 
Table 6. Records of ground-water levels in the vicinity of Killbuck Creek valley, near Wooster, Ohio-Continued

\begin{tabular}{llllll}
\hline & Water & Water & Water \\
Date & level & Date & level & Date & level \\
\hline
\end{tabular}

Local Nnmber: WN-K4

JUN 20, 1985

JUN 24, 1985

JUL 01, 1985

.56

.81

1.00

HIGHEST

LOWEST

.56

2.48

Local Number: WN-K5

JUN 24, 1985

JUL 01, 1985

1.51

1.97

HIGHEST

1.51

LOWEST

5.44

Local Number: WN.K6

JUN 24, 1985

1.44

JUL 01, 1985

1.91

HIGHEST

LOWEST

1.44

5.48

Local Number: WN-K7

JUN 24, 1985

3.57

JUL 01,1985

3.98

HIGHEST

3.57

LOWEST

6.40

Locai Number: WN-K8

JUL 01, 1985

JUL 02, 1985

DRY

DRY

Local Number: WN-K9

JUL 02, 1985

$-.18$

JUL 16, 1985

$-.13$

HIGHEST

LOWEST

$-.40$

Local Number: WN-K10

JUL 03, 1985

9.36

HIGHEST

LOWEST

9.36

DRY

Stratified-drift aquifer streambed plezometers - Continued

Statlon Number: $\mathbf{4 0 4 8 2 5 0 8 1 5 8 4 9 0 2}$

JUL 17, 1985

AUG 27, 1985

1.21

SEP 23, 1985

2.36

JUN 20, 1985

SEP 30, 1985

Station Number: 404818081584401

JUL 17; 1985

AUG 27, 1985

2.58

4.02

JUN 24, 1985

SEP 30, 1985

Station Number: $\mathbf{4 0 4 8 1 8 0 8 1 5 8 4 4 0 2}$

JUL $17,1985 \quad 2.54$

AUG 27, 1985

3.94

JUN 24, 1985

SEP 30, 1985

Station Number: $\mathbf{4 0 4 8 1 3 0 8 1 5 8 4 1 0 0}$

JUL 17, 1985

4.55

AUG 27, 1985

6.28

JUN 24, 1985

SEP 23, 1985

Station Number: $\mathbf{4 0 4 7 5 9 0 8 1 5 8 2 8 0 0}$

AUG 14, 1985 DRY

AUG 27, 1985

DRY

Station Number: $\mathbf{4 0 4 8 3 9 0 8 1 5 8 5 2 0 2}$

AUG 28, $1985 \quad-.40$

SEP 23, 1985

AUG 28, 1985

SEP 23, 1985

Station Number: 404735081580300

JUL 28, 1985

10.55

JUL 03, 1985
SEP 30, 1985

Datum: 848.3 ft

2.48

SEP 23, 1985

SEP 30, 1985

Datum: $846.4 \mathrm{n}$

5.28

5.44

SEP 23, 1985

SEP 30, 1985

Datum: $846.4 \mathrm{ft}$

5.01

5.48

SEP 23, 1985

SEP 30, 1985

Datum: $847.0 \mathrm{ft}$

6.40

6.30

SEP 23, 1985

Datum: $846.0 \mathrm{ft}$

DRY

DRY

Datum: 851.2 f

SEP 30, 1985

0.11

Datum: 849 n

AUG 28, 1985

DRY 
Table 6. Records of ground-water levels in the vicinity of Killbuck Creek valley, near Wooster, Ohio-Continued

\begin{tabular}{|c|c|c|c|c|c|}
\hline Date & $\begin{array}{l}\text { Water } \\
\text { level }\end{array}$ & Date & $\begin{array}{l}\text { Water } \\
\text { level }\end{array}$ & Date & $\begin{array}{l}\text { Water } \\
\text { level }\end{array}$ \\
\hline \multicolumn{6}{|c|}{ Shale-sundstone aqnifer } \\
\hline \multicolumn{2}{|c|}{ Local Nnmber: WN-14 } & \multicolumn{3}{|c|}{ Statlon Nnmber: 404758081585900 } & Datnm: $866.0 \mathrm{ft}$ \\
\hline NOV 09, 1984 & 25.40 & NOV 28,1984 & 25.17 & DEC 13, 1984 & 25.32 \\
\hline HIGHEST & 25.17 & NOV 28, 1984 & & & \\
\hline LOWEST & 25.40 & NOV 09, 1984 & & & \\
\hline \multicolumn{2}{|c|}{ Local Nnmber: WN-15 } & \multicolumn{3}{|c|}{ Station Nnmber: 404736081585500} & Datum: $910 \mathrm{ft}$ \\
\hline NOV 29,1984 & 25.54 & MAR 05, 1985 & 25.02 & AUG 28, 1985 & 26.54 \\
\hline JAN 18,1985 & 25.22 & MAR 21, 1985 & 25.10 & APR 15, 1986 & 25.66 \\
\hline HIGHEST & 25.02 & MAR 05, 1985 & & & \\
\hline LOWEST & 26.54 & AUG 28, 1985 & & & \\
\hline \multicolumn{2}{|c|}{ Local Nnmber: WN-16 } & \multicolumn{3}{|c|}{ Statlon Nnmber: 404809082000000} & Datnm: 1,055 n \\
\hline NOV 29,1984 & 65.85 & MAR 05, 1985 & 63.74 & MAR 21, 1985 & 64.36 \\
\hline HIGHEST & 63.74 & MAR 05, 1985 & & & \\
\hline LOWEST & 65.85 & NOV 29,1984 & & & \\
\hline \multicolumn{2}{|c|}{ Local Number: WN-18 } & \multicolumn{3}{|c|}{ Statlon Nnmber: 404759081590800} & Datum: $911.5 \mathrm{ft}$ \\
\hline JUL 03, 1985 & 53.36 & AUG 28, 1985 & & & \\
\hline JUL 18, 1985 & 54.45 & SEP 23,19855 & & & \\
\hline HIGHEST & 53.36 & JUL 03, 1985 & & & \\
\hline LOWEST & 55.75 & SEP 23,1985 & & & \\
\hline \multicolumn{2}{|c|}{ Local Nnmber: WN-19 } & \multicolumn{3}{|c|}{ Station Nnmber: 404837081592900} & Datnm: $888.5 \mathrm{ft}$ \\
\hline NOV 29,1984 & 35.95 & JUL 02,1985 & 34.56 & SEP 23, 1985 & $39.01 \mathrm{P}$ \\
\hline MAR 21, 1985 & 34.87 & AUG 13,1985 & 35.20 & & \\
\hline HIGHEST & 34.56 & JUL 02, 1985 & & & \\
\hline LOWEST & 35.95 & NOV 29,1984 & & & \\
\hline \multicolumn{2}{|c|}{ Local Nnmber: WN-20 } & \multicolumn{3}{|c|}{ Station Nnmber: 404802081594100} & Datnm: 1,010 ft \\
\hline NOV 29,1984 & 29.32 & MAR 21, 1985 & 26.69 & MAY 03, 1985 & 27.39 \\
\hline HIGHEST & 26.69 & MAR 21, 1985 & & & \\
\hline LOWEST & 29.32 & NOV 29,1984 & & & \\
\hline
\end{tabular}


Table 19. Water-quality records for ground-water and surface-water samples, Killbuck Creek valley near Wooster, Ohio

\section{Explanation of Column Headings}

All columns A double dash indicates information not available or not applicable.

A less than symbol $(<)$ indicates value is less than the value shown.

Local Idemifier Local well number, spring number, or stream site shown on Plate I.

Wayne County prefix, WN-, is omitted from well and spring numbers on Plate 1.

Letters in well number suffix signify the following:

$$
\begin{aligned}
& \mathrm{K}-\text { streambed piezometer, } \\
& \mathrm{P} \text {-city production well; } \\
& \mathrm{S}-\text { shallow observation well; } \\
& \mathrm{D} \text {-deep observation well. }
\end{aligned}
$$

Stream sites are abbreviated as follows:

CC AT USR - CLEAR CREEK AT UPPER SILVER ROAD BRIDGE AT WOOSTER, OHIO

KBC AT SR-KILLBUCK CREEK AT SILVER ROAD AT WOOSTER, OHIO

KBC AT OMR - KILLBUCK CREEK AT OLD MANSFIELD ROAD AT WOOSTER, OHIO

Station number

15-digit unique identifier based on site latitude (first six digits), longitude (digits seven through thirteen), and a 2-digit sequence-number suffix. An 8-digit identifier (03138800) is used for one stream location that was used prior to this study for the collection of streamflow data.

Type of site

DGW, ground water from well in stratified-drift aquifer, DSP, spring water from stratified-drift aquifer, RGW, ground water from well in shale-sandstone aquifer, SW, stream water; SGW, ground water from piezometer in streambed.

$\underline{\text { Water level }}$

The depth to water in the well, in feet below the land surface at the well site. A negative value indicates that water level is above land surface.

\section{Abbreviations}

$\mu \mathrm{S} / \mathrm{cm}$, microsiemens per centimetci at $25 \mathrm{deg} . \mathrm{C}$

Eh, oxidation-reduction potential

mv, millivolts

deg. C, degrees Celsius

Ing/L, milligrams per Liter

$\mathrm{mg} / \mathrm{L}$, micrograms per Liter

$\delta \mathrm{D}$, hydrogen $\left({ }^{2} \mathrm{H} /{ }^{1} \mathrm{H}\right.$ )stable isotope ratio, in parts per thousand (per mil) relative to the standard, SMOW (Standard Mean

Ocean Water)

per mil, parts per thousand

$\delta^{18} \mathrm{O}$, oxygen $\left({ }^{18} \mathrm{O} /{ }^{16} \mathrm{O}\right.$ ) stable isotope ratio, in parts per thousand (per mil) relative to the standard, SMOW (Standard Mean

Ocean Water)

inst., instantaneous

$\mathrm{ft}^{3} / \mathrm{s}$, cubic feet per second

WH, whole water, unfiltered sample

FET, fixed-endpoint on-site titration for alkalimity

T.U., Tritium Units 
Table 19. Water-quality records for ground-water and surface-water samples, Killbuck Creek valley near Wooster, Ohio-Continued

Sample 1: September 11-12, 1984

\begin{tabular}{|c|c|c|c|c|c|c|c|c|c|}
\hline $\begin{array}{l}\text { Local } \\
\text { identifier }\end{array}$ & $\begin{array}{l}\text { Station } \\
\text { number }\end{array}$ & Date & $\begin{array}{c}\text { Type } \\
\text { of } \\
\text { site }\end{array}$ & Time & $\begin{array}{l}\text { Water } \\
\text { levei }\end{array}$ & $\begin{array}{c}\text { Spe- } \\
\text { cific } \\
\text { con- } \\
\text { duct- } \\
\text { ance } \\
(\mu S / c m)\end{array}$ & $\begin{array}{l}\text { pH } \\
\text { (stand- } \\
\text { ard } \\
\text { units) }\end{array}$ & $\begin{array}{c}\text { Eh } \\
\text { (mv) }\end{array}$ & $\begin{array}{c}\text { Temper- } \\
\text { ature, } \\
\text { air } \\
\text { (deg. C) }\end{array}$ \\
\hline P4 & 404801081583300 & $09-12-84$ & DGW & 1550 & -- & 660 & 6.8 & 180 & 28.0 \\
\hline P5 & 404800081583100 & $09-12-84$ & DGW & 1525 & $\ldots$ & 1010 & 6.8 & 190 & 28.0 \\
\hline D2 & 404802081583102 & $09-12-84$ & DGW & 1420 & 33.58 & 545 & 6.9 & 130 & 28.0 \\
\hline S5 & 404800081584501 & $09-12-84$ & DGW & 1800 & 22.93 & 815 & 6.6 & 180 & 27.0 \\
\hline D6 & 404839081590900 & $09-11-84$ & DGW & 1215 & 5.50 & 500 & 7.4 & 90 & 27.5 \\
\hline S8 & 404805081582600 & $09-12-84$ & DGW & 0955 & 24.76 & 575 & 6.7 & 370 & 17.0 \\
\hline D9 & 404805081582601 & $09-12-84$ & DGW & 1200 & 29.41 & 565 & 7.1 & 160 & 27.0 \\
\hline D10 & 404752081583400 & $09-11-84$ & DGW & 1445 & 31.48 & 755 & 6.7 & 200 & 28.0 \\
\hline $\mathrm{D} 12$ & 404744081582100 & $09-11.84$ & DGW & 1645 & 27.22 & 815 & 6.8 & 200 & 28.0 \\
\hline KBC AT OMR & 03138800 & $09-11-84$ & SW & 0935 & -. & 750 & 7.4 & -. & 23.0 \\
\hline
\end{tabular}

\begin{tabular}{|c|c|c|c|c|c|c|c|c|c|}
\hline $\begin{array}{l}\text { Locai } \\
\text { Identifier }\end{array}$ & Date & \multicolumn{2}{|c|}{$\begin{array}{c}\text { Temper- } \\
\text { ature, } \\
\text { water } \\
\text { (deg. C) } \\
\end{array}$} & $\begin{array}{l}\text { Oxygen, } \\
\text { dis- } \\
\text { solved } \\
\text { (mg/L) }\end{array}$ & $\begin{array}{c}\text { Oxygen, } \\
\text { dls- } \\
\text { soived } \\
\text { (percent } \\
\text { satur- } \\
\text { ation) }\end{array}$ & $\begin{array}{c}\text { Hard- } \\
\text { ness, } \\
\text { total } \\
\text { (mg/L } \\
\text { as } \\
\mathrm{CaCO}_{3} \text { ) }\end{array}$ & $\begin{array}{c}\text { Acidity } \\
\text { (mg/h } \\
\text { as H) }\end{array}$ & $\begin{array}{c}\text { Caiclum, } \\
\text { dis- } \\
\text { soived } \\
\text { (mg/ } \\
\text { as } \mathrm{Ca} \text { ) }\end{array}$ & $\begin{array}{l}\text { Magne- } \\
\text { slum, } \\
\text { dis- } \\
\text { solved } \\
\text { (mg/L } \\
\text { as Mg) }\end{array}$ \\
\hline $\mathrm{P} 4$ & $09-12-84$ & \multicolumn{2}{|c|}{10.5} & $<0.1$ & -. & 310 & 0.2 & 95 & 18 \\
\hline P5 & $09-12-84$ & \multicolumn{2}{|c|}{10.5} & 0.4 & 4 & 390 & 0.2 & 120 & 23 \\
\hline D2 & $09-12-84$ & \multicolumn{2}{|c|}{11.0} & $<0.1$ & -- & 260 & 0.3 & 76 & 17 \\
\hline S5 & $09-12-84$ & \multicolumn{2}{|c|}{11.5} & $<0.1$ & -- & 370 & $<0.1$ & 110 & 23 \\
\hline D6 & $09-11-84$ & \multicolumn{2}{|c|}{12.0} & 0.2 & 2 & 240 & $<0.1$ & 66 & 18 \\
\hline S8 & $09-12-84$ & \multicolumn{2}{|c|}{11.0} & $<0.1$ & -- & 270 & 0.1 & 81 & 16 \\
\hline D9 & $09-12-84$ & \multicolumn{2}{|c|}{11.5} & $<0.1$ & -- & 220 & 0.1 & 59 & 17 \\
\hline D10 & $09-11-84$ & \multicolumn{2}{|c|}{12.0} & $<0.1$ & -- & 360 & $<0.1$ & 110 & 20 \\
\hline D12 & $09-11-84$ & \multicolumn{2}{|c|}{10.0} & $<0.1$ & -- & 390 & $<0.1$ & 120 & 22 \\
\hline KBC AT OMR & $09-11-84$ & \multicolumn{2}{|c|}{18.5} & 8.1 & 88 & 340 & 0.2 & 94 & 26 \\
\hline $\begin{array}{l}\text { Local } \\
\text { Identifier }\end{array}$ & Date & $\begin{array}{c}\text { Sodium, } \\
\text { dis- } \\
\text { solved } \\
\text { (mg/L } \\
\text { as Na) }\end{array}$ & $\begin{array}{l}\text { Sodium, } \\
\text { percent }\end{array}$ & $\begin{array}{c}\text { Sodium } \\
\text { ad } \\
\text { sorp- } \\
\text { tlon } \\
\text { ratio } \\
\end{array}$ & $\begin{array}{l}\text { Potas- } \\
\text { slum, } \\
\text { dis- } \\
\text { solved } \\
\text { (mg/L } \\
\text { as K) } \\
\end{array}$ & $\begin{array}{c}\text { Blcar. } \\
\text { bonate, } \\
\text { WH FET, } \\
\text { fleld } \\
(\mathrm{mg} / \mathrm{Las} \\
\mathrm{HCO} \text { ) }\end{array}$ & $\begin{array}{c}\text { Alka- } \\
\text { linity, } \\
\text { WH FET, } \\
\text { field } \\
\text { (mg/L as } \\
\left.\mathrm{CaCO}_{3}\right)\end{array}$ & $\begin{array}{l}\text { Sulfate, } \\
\text { dls- } \\
\text { soived } \\
\text { (mg/L } \\
\text { as } \mathrm{SO}_{4} \text { ) }\end{array}$ & $\begin{array}{l}\text { Chlo- } \\
\text { ride, } \\
\text { dis- } \\
\text { solved } \\
(\mathrm{mg} / \mathrm{h} \\
\text { as Cl) }\end{array}$ \\
\hline P4 & $09-12-84$ & 19 & 12 & 0.5 & 1.4 & 310 & 251 & 62 & 46 \\
\hline P5 & $09-12-84$ & 57 & 24 & 1 & 1.6 & 410 & 333 & 84 & 110 \\
\hline D2 & $09-12-84$ & 14 & 10 & 0.4 & 1.3 & 240 & 200 & 64 & 34 \\
\hline S5 & $09-12-84$ & 25 & 13 & 0.6 & 1.7 & 400 & 325 & 78 & 55 \\
\hline D6 & $09-11-84$ & 10 & 8 & 0.3 & 1.2 & 240 & 196 & 39 & 36 \\
\hline
\end{tabular}


Table 19. Water-quality records for ground-water and surface-water samples, Killbuck Creek valley near Wooster, Ohio-Continued

Sample 1: September 11-12, 1984-Continued

\begin{tabular}{|c|c|c|c|c|c|c|c|c|c|}
\hline $\begin{array}{l}\text { Local } \\
\text { Identlfier }\end{array}$ & Date & $\begin{array}{c}\text { Sodlum, } \\
\text { dls- } \\
\text { solved } \\
\text { (mg/L } \\
\text { as } \mathrm{Na}) \\
\end{array}$ & $\begin{array}{l}\text { Sodlum, } \\
\text { percent } \\
\end{array}$ & $\begin{array}{l}\text { Sodlum } \\
\text { ad- } \\
\text { sorp- } \\
\text { tion } \\
\text { ratio } \\
\end{array}$ & $\begin{array}{l}\text { Potas- } \\
\text { slum, } \\
\text { dls- } \\
\text { solved } \\
\text { (mg/L } \\
\text { as K) } \\
\end{array}$ & $\begin{array}{c}\text { Bicar- } \\
\text { bonate, } \\
\text { WH FET, } \\
\text { fleld } \\
\text { (mg/L as } \\
\left.\mathrm{HCO}_{3}\right) \\
\end{array}$ & $\begin{array}{c}\text { Alka- } \\
\text { Ilnity, } \\
\text { WH FET, } \\
\text { field } \\
(\mathrm{mg} / \mathrm{L} \text { as } \\
\left.\mathrm{CaCO}_{3}\right)\end{array}$ & $\begin{array}{c}\text { Sulfate, } \\
\text { dls- } \\
\text { solved } \\
\text { (mg/L } \\
\left.\text { as } \mathrm{SO}_{4}\right) \\
\end{array}$ & $\begin{array}{l}\text { Chlo- } \\
\text { ilde, } \\
\text { dls- } \\
\text { solved } \\
\text { (mg/L } \\
\text { as Cl) } \\
\end{array}$ \\
\hline S8 & $09-12-84$ & 13 & 9 & 0.3 & 2.2 & 260 & 213 & 46 & 29 \\
\hline D9 & $09-12-84$ & 30 & 23 & 0.9 & 2.1 & 270 & 217 & 40 & 59 \\
\hline D10 & $09-11-84$ & 23 & 12 & 0.5 & 1.2 & 380 & 313 & 49 & 52 \\
\hline D12 & $09-11-84$ & 21 & 10 & 0.5 & 1.8 & 440 & 361 & 55 & 48 \\
\hline KBC AT OMR & $09-11-84$ & 21 & 12 & 0.5 & 3.9 & 240 & 193 & 160 & 43 \\
\hline $\begin{array}{l}\text { Local } \\
\text { Ident|fier }\end{array}$ & Date & $\begin{array}{l}\text { Fluo- } \\
\text { rlde, } \\
\text { dle- } \\
\text { solved } \\
\text { (mg/L } \\
\text { as F) } \\
\end{array}$ & $\begin{array}{c}\text { Bromlde, } \\
\text { dls- } \\
\text { solved } \\
\text { (mg/L } \\
\text { as Br) } \\
\end{array}$ & $\begin{array}{c}\text { Slllca, } \\
\text { dle- } \\
\text { solved } \\
\text { (mg/L } \\
\text { as } \\
\mathrm{SIO}_{2} \text { ) } \\
\end{array}$ & $\begin{array}{c}\text { Solids, } \\
\text { residue } \\
\text { at } 180 \\
\text { deg. C, } \\
\text { dis- } \\
\text { solved } \\
\text { (mg'th) } \\
\end{array}$ & $\begin{array}{c}\text { Sollds, } \\
\text { sum of } \\
\text { constl- } \\
\text { tuents, } \\
\text { dls- } \\
\text { solved } \\
\text { (mg/L) } \\
\end{array}$ & 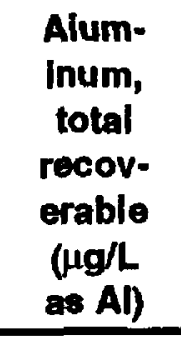 & $\begin{array}{l}\text { Alum- } \\
\text { Inum, } \\
\text { dls- } \\
\text { solved } \\
(\mu g / L \\
\text { as Al) } \\
\end{array}$ & $\begin{array}{c}\text { Iron, } \\
\text { total } \\
\text { recov- } \\
\text { orable } \\
(\mu g / L \\
\text { as } \mathrm{Fe}) \\
\end{array}$ \\
\hline P4 & $09-12-84$ & 0.1 & 0.12 & 11 & 403 & 406 & 20 & $<10$ & 2600 \\
\hline P5 & $09-12-84$ & $<0.1$ & 0.14 & 13 & 743 & 612 & $<10$ & $<10$ & 3600 \\
\hline D2 & $09-12-84$ & 0.1 & 0.060 & 9.1 & 341 & 337 & 620 & $<10$ & 6800 \\
\hline \$5 & $09-12-84$ & $<0.1$ & 0.10 & 19 & 497 & 509 & 8700 & $<10$ & 26000 \\
\hline D6 & $09-11-84$ & $<0.1$ & 0.10 & 9.7 & 367 & 298 & 710 & $<10$ & 9300 \\
\hline S8 & $09-12-84$ & 0.1 & 0.090 & 8.8 & 371 & 325 & 110 & $<10$ & 860 \\
\hline D9 & $09-12-84$ & 0.1 & 0.22 & 12 & 403 & 350 & 30 & 10 & 55000 \\
\hline D10 & $09-11.84$ & 0.1 & 0.10 & 15 & 557 & 461 & 20 & 10 & 2100 \\
\hline D12 & $09-11-84$ & 0.1 & 0.13 & 12 & 615 & 499 & 1000 & $<10$ & 15000 \\
\hline KBC AT OMR & $09-11-84$ & 0.2 & 0.19 & 7.7 & 548 & 472 & 530 & $<10$ & 1800 \\
\hline
\end{tabular}

\begin{tabular}{|c|c|c|c|c|c|c|c|c|}
\hline $\begin{array}{l}\text { Local } \\
\text { Identifier }\end{array}$ & Date & $\begin{array}{l}\text { Iron, } \\
\text { dls- } \\
\text { solved } \\
\text { ( } \mu \mathrm{g} / \mathrm{L} \\
\text { as Fe) }\end{array}$ & $\begin{array}{l}\text { Lithlum, } \\
\text { dls- } \\
\text { solved } \\
\text { ( } \mu \mathrm{g} / \mathrm{L} \\
\text { as L) }\end{array}$ & $\begin{array}{c}\text { Manga- } \\
\text { nese, } \\
\text { total } \\
\text { recov- } \\
\text { ersble } \\
(\mu g / L \\
\text { as } M n)\end{array}$ & $\begin{array}{l}\text { Manga- } \\
\text { nese, } \\
\text { dls- } \\
\text { solved } \\
\text { ( } \mu g / L \\
\text { as Mn) }\end{array}$ & $\begin{array}{l}\text { Stron- } \\
\text { tium, } \\
\text { dle- } \\
\text { solved } \\
\text { ( } \mu \mathrm{g} / \mathrm{L} \\
\text { as Sr) }\end{array}$ & $\begin{array}{l}\delta \mathrm{D}, \\
\text { per } \\
\text { mil }\end{array}$ & $\begin{array}{c}\delta^{18} \mathrm{O} \\
\text { per } \\
\mathrm{mll}\end{array}$ \\
\hline P4 & $09-12-84$ & 2200 & 11 & 230 & 210 & 160 & -57.5 & -8.70 \\
\hline P5 & $09-12-84$ & 3100 & 10 & 220 & 220 & 190 & -57.5 & -8.75 \\
\hline D2 & $09-12-84$ & 960 & 9 & 160 & 43 & 130 & -60.0 & -9.05 \\
\hline S5 & $09-12-84$ & $15(x)$ & 13 & 1100 & 670 & 260 & -55.0 & -8.40 \\
\hline D6 & $09-11-84$ & 750 & 5 & 190 & 35 & 120 & -54.5 & -8.60 \\
\hline S8 & $(19-12-84$ & 4 & 8 & 420 & 420 & 130 & -59.0 & -8.95 \\
\hline D9 & $09-12-84$ & 380 & 12 & 1000 & 73 & 200 & -56.0 & -8.60 \\
\hline D10 & $09-11-84$ & 2000 & 9 & 480 & 490 & 230 & -57.5 & -8.70 \\
\hline $\mathrm{D} 12$ & $09-11-84$ & 2200 & 7 & 570 & 360 & 220 & -62.0 & -9.25 \\
\hline KBC AT OMR & $09-11-84$ & 10 & 6 & 180 & 110 & 260 & -48.0 & -7.25 \\
\hline
\end{tabular}


T.able 19. Water-quality records for ground-water and surface-water samples, Killbuck Creek valley near Wooster, Ohio-Continued

Sample 2: November 7-8, 1984

\begin{tabular}{|c|c|c|c|c|c|c|c|c|c|}
\hline $\begin{array}{l}\text { Local } \\
\text { Identlifier }\end{array}$ & Station number & Date & $\begin{array}{l}\text { Type } \\
\text { of } \\
\text { site }\end{array}$ & Time & $\begin{array}{l}\text { Water } \\
\text { ievel } \\
\text { (feot) }\end{array}$ & $\begin{array}{c}\text { Dis- } \\
\text { charge, } \\
\text { Inst. } \\
\left(\mathrm{ft}^{3} / \mathrm{s}\right)\end{array}$ & $\begin{array}{l}\text { Spo- } \\
\text { ciflc } \\
\text { con- } \\
\text { duct- } \\
\text { ance } \\
(\mu \mathrm{S} / \mathrm{cm})\end{array}$ & $\begin{array}{l}\text { pH } \\
\text { (stand- } \\
\text { ard } \\
\text { units) }\end{array}$ & $\begin{array}{l}\text { Eh } \\
\text { (mv) }\end{array}$ \\
\hline P4 & 404801081583300 & $11-07-84$ & DGW & 1600 & -- & .- & 670 & 7.0 & 160 \\
\hline P5 & 404800081583100 & $11-07-84$ & DGW & 1525 & -- & -- & 1060 & 6.9 & 160 \\
\hline D6 & 404839081590900 & $11-07-84$ & DGW & 1335 & 4.61 & -- & 495 & 7.5 & 90 \\
\hline CC AT USR & 404848081580900 & $11-08-84$ & sw & 1325 & -- & -- & 430 & 7.5 & -. \\
\hline KBC AT SR & 404838081585200 & $11-08-84$ & SW & 1030 & -- & 67 & 545 & 7.6 & -. \\
\hline
\end{tabular}

\begin{tabular}{|c|c|c|c|c|c|c|c|c|c|}
\hline $\begin{array}{l}\text { Local } \\
\text { Identifier }\end{array}$ & Date & $\begin{array}{c}\text { Temper- } \\
\text { ature, } \\
\text { alr, } \\
\text { (deg. C) }\end{array}$ & $\begin{array}{c}\text { Temper- } \\
\text { ature, } \\
\text { water } \\
\text { (deg. C) } \\
\end{array}$ & $\begin{array}{c}\text { Oxygen, } \\
\text { dis- } \\
\text { solved } \\
\text { (mg/L) } \\
\end{array}$ & $\begin{array}{c}\text { Oxygen, } \\
\text { dis- } \\
\text { soived } \\
\text { (percent } \\
\text { satur- } \\
\text { ation) } \\
\end{array}$ & $\begin{array}{c}\text { Hard- } \\
\text { ness, } \\
\text { total } \\
\text { (mg/L } \\
\mathrm{as} \\
\left.\mathrm{CaCO}_{3}\right) \\
\end{array}$ & $\begin{array}{ll} & \mathrm{Ca} \\
& \\
\text { Acidity } \\
(\mathrm{mg} / \mathrm{L} \\
\mathrm{as} \mathrm{H})\end{array}$ & $\begin{array}{c}\text { Calcium, } \\
\text { dls- } \\
\text { soived } \\
\text { (mg/L } \\
\text { as Ca) } \\
\end{array}$ & $\begin{array}{c}\text { Magne- } \\
\text { sium, } \\
\text { dlis- } \\
\text { soived } \\
(\mathrm{mg} / \mathrm{h} \\
\text { as Mg) } \\
\end{array}$ \\
\hline P4 & $11-07-84$ & 12.0 & 10.5 & $<0.1$ & .. & 310 & 0.3 & 94 & 19 \\
\hline P5 & $11-07-84$ & 12.0 & 10.0 & $<0.1$ & -- & 390 & 0.4 & 120 & 23 \\
\hline D6 & $11-07-84$ & 11.0 & 11.5 & $<0.1$ & -- & 240 & 0.3 & 67 & 18 \\
\hline CC AT USR & $11-08-84$ & 12.0 & 8.0 & 11.6 & 100 & 180 & 0.1 & 47 & 15 \\
\hline KBC AT SR & $11-08-84$ & 11.0 & 6.0 & 10.1 & 83 & 220 & 0.1 & 60 & 17 \\
\hline $\begin{array}{l}\text { Local } \\
\text { identifler }\end{array}$ & Date & $\begin{array}{c}\text { Sodlum, } \\
\text { dls- } \\
\text { solved } \\
\text { (mg/L } \\
\text { as } \mathrm{Na} \text { ) }\end{array}$ & $\begin{array}{l}\text { Sodlum, } \\
\text { percent }\end{array}$ & $\begin{array}{l}\text { Sodlum } \\
\text { ad- } \\
\text { sorp- } \\
\text { tlon } \\
\text { ratio }\end{array}$ & $\begin{array}{l}\text { Potas- } \\
\text { slum, } \\
\text { dis- } \\
\text { solved } \\
\text { (mg/L } \\
\text { as K) }\end{array}$ & $\begin{array}{c}\text { Blcar- } \\
\text { bonate, } \\
\text { WH FET, } \\
\text { field } \\
\left(\mathrm{mg}^{\prime} \mathrm{Las}^{2}\right. \\
\left.\mathrm{HCO}_{3}\right)\end{array}$ & $\begin{array}{c}\text { Alka- } \\
\text { IInity, } \\
\text { WH FET, } \\
\text { field } \\
(\mathrm{mg} / \mathrm{L} \text { as } \\
\left.\mathrm{CaCO}_{3}\right)\end{array}$ & \multicolumn{2}{|c|}{$\begin{array}{c}\text { Sulfalo, } \\
\text { dis- } \\
\text { solved } \\
\text { (mg/L } \\
\left.\mathrm{as} \mathrm{SO}_{4}\right) \\
\end{array}$} \\
\hline p4 & $11-07-84$ & 19 & 12 & 0.5 & 1.5 & 290 & 238 & \multicolumn{2}{|c|}{58} \\
\hline P5 & $11-07-84$ & 62 & 25 & 1 & 1.7 & 380 & 308 & \multicolumn{2}{|c|}{75} \\
\hline D6 & $11-07-84$ & 10 & 8 & 0.3 & 1.3 & 220 & 180 & \multicolumn{2}{|c|}{37} \\
\hline CC AT USR & $11-08-84$ & 12 & 12 & 0.4 & 3.3 & -- & 93 & \multicolumn{2}{|c|}{41} \\
\hline KBC AT SR & $11-08-84$ & 19 & 15 & 0.6 & 5.3 & 160 & 130 & \multicolumn{2}{|c|}{67} \\
\hline
\end{tabular}


Table 19. Water-quality records for ground-water and surface-water samples, Killbuck Creek valley near Wooster, Ohio-Continued

Sample 2: November 7-8, 1984-Continued

\begin{tabular}{|c|c|c|c|c|c|c|c|c|}
\hline $\begin{array}{l}\text { Locai } \\
\text { Identifier }\end{array}$ & Date & $\begin{array}{l}\text { Chio- } \\
\text { ride, } \\
\text { dls } \\
\text { solved } \\
\text { (mgh } \\
\text { as Ci) } \\
\end{array}$ & $\begin{array}{l}\text { Fluo- } \\
\text { ride, } \\
\text { dls- } \\
\text { solved } \\
\text { (mg/L } \\
\text { as F) } \\
\end{array}$ & $\begin{array}{c}\text { Silica, } \\
\text { dis- } \\
\text { soived } \\
\text { (mgll } \\
\text { as } \\
\mathrm{SiO}_{2} \text { ) }\end{array}$ & $\begin{array}{c}\text { Sollds, } \\
\text { residue } \\
\text { at } 180 \\
\text { deg. C, } \\
\text { dis- } \\
\text { solved } \\
\text { (mg/L) }\end{array}$ & $\begin{array}{c}\text { Solids, } \\
\text { sum of } \\
\text { consti- } \\
\text { tuents, } \\
\text { dis- } \\
\text { soived } \\
\text { (mg/L) } \\
\end{array}$ & $\begin{array}{l}\text { Solids, } \\
\text { dis- } \\
\text { solved } \\
\text { (tons } \\
\text { per } \\
\text { day) } \\
\end{array}$ & $\begin{array}{l}\text { Aium- } \\
\text { inum, } \\
\text { totai } \\
\text { recov- } \\
\text { erable } \\
(\mu \mathrm{g} / \mathrm{L} \\
88 \mathrm{Al}) \\
\end{array}$ \\
\hline P4 & $11-07-84$ & 48 & $<0.1$ & 12 & 421 & 396 & -- & 30 \\
\hline P5 & $11-07-84$ & 130 & $<0.1$ & 14 & 646 & 614 & -- & 20 \\
\hline D6 & $11-07-84$ & 36 & $<0.1$ & 9.9 & 282 & 288 & - & 250 \\
\hline CC AT USR & $11-08-84$ & 32 & 0.1 & 7.9 & 262 & 214 & -- & 30 \\
\hline KBC AT SR & $11-08-84$ & 41 & 0.1 & 8.0 & 330 & 296 & 59.7 & 120 \\
\hline $\begin{array}{l}\text { Local } \\
\text { identifier }\end{array}$ & Date & $\begin{array}{l}\text { Alum- } \\
\text { Inum, } \\
\text { dis- } \\
\text { solved } \\
\text { ( } \mu \mathrm{g} / \mathrm{L} \\
\text { as Ai) }\end{array}$ & $\begin{array}{l}\text { Iron, } \\
\text { totai } \\
\text { recov- } \\
\text { erabie } \\
(\mu \mathrm{g} / \\
\text { as } \mathrm{Fe})\end{array}$ & $\begin{array}{l}\text { Iron, } \\
\text { dis- } \\
\text { solved } \\
\text { ( } \mu \mathrm{g} / \mathrm{L} \\
\text { as Fe) }\end{array}$ & $\begin{array}{c}\text { Manga- } \\
\text { nese, } \\
\text { total } \\
\text { recov- } \\
\text { erable } \\
(\mu g / L \\
\text { as } \mathrm{Mn})\end{array}$ & $\begin{array}{l}\text { Manga- } \\
\text { nese, } \\
\text { dis- } \\
\text { solved } \\
(\mu \mathrm{g} / \mathrm{L} \\
\text { as Mn) }\end{array}$ & $\begin{array}{l}\delta \mathrm{D}, \\
\text { per } \\
\text { mil }\end{array}$ & $\begin{array}{c}\delta^{18} \mathrm{O} \\
\text { per } \\
\mathrm{mli}\end{array}$ \\
\hline P4 & $11-07-84$ & 20 & 2200 & 2100 & 230 & 200 & -55.5 & -8.60 \\
\hline P5 & $11-07-84$ & 20) & 6800 & 3000 & 250 & 210 & -57.0 & -8.75 \\
\hline D6 & $11-07-84$ & 30 & 3300 & 740 & 100 & 35 & -57.0 & -8.60 \\
\hline CC AT USR & $11-08-84$ & 20 & 100 & 17 & 20 & 13 & -53.5 & -8.30 \\
\hline KBC AT SR & $11-08-84$ & 30 & 620 & 48 & 90 & 59 & -47.0 & -7.35 \\
\hline
\end{tabular}

Sample 3: November 26-28, 1984

\begin{tabular}{|c|c|c|c|c|c|c|c|c|c|}
\hline $\begin{array}{l}\text { Local } \\
\text { identifier }\end{array}$ & Station number & Date & $\begin{array}{c}\text { Type } \\
\text { of } \\
\text { site } \\
\end{array}$ & Time & $\begin{array}{c}\text { Water } \\
\text { level } \\
\text { (feet) }\end{array}$ & $\begin{array}{c}\text { Dis- } \\
\text { charge, } \\
\text { Inst. } \\
\left(\mathrm{fr}^{3} / \mathrm{s}\right) \\
\end{array}$ & $\begin{array}{l}\text { Spe- } \\
\text { cific } \\
\text { con- } \\
\text { duct- } \\
\text { ance } \\
(\mu S / c m)\end{array}$ & $\begin{array}{c}\text { pH } \\
\text { (stand- } \\
\text { ard } \\
\text { units) } \\
\end{array}$ & $\begin{array}{c}\text { Eh } \\
\text { (mv) }\end{array}$ \\
\hline P4 & 404801081583300 & $11-28-84$ & DGW & 1530 & -- & -- & 680 & 6.8 & 170 \\
\hline P5 & 404800081583100 & $11-28-84$ & DGW & 1615 & -- & -- & 1030 & 6.7 & 170 \\
\hline D2 & 404802081583102 & $11-28-84$ & DGW & 1045 & 34.10 & -- & 720 & 7.0 & 140 \\
\hline S5 & 404800081584501 & $11-26-84$ & DGW & 1420 & 23.20 & -- & 850 & 6.9 & 160 \\
\hline D6 & 404839081590900 & $11-26-84$ & DGW & 1545 & 5.44 & -- & 510 & 7.6 & 80 \\
\hline S8 & 404805081582600 & $11-26-84$ & DGW & 1135 & 26.28 & -- & 540 & 7.2 & 280 \\
\hline D9 & 404805081582601 & $11-26-84$ & DGW & 1235 & 30.77 & -- & 565 & 7.5 & 120 \\
\hline D10 & 404752081583400 & $11-27-84$ & DGW & 0855 & 31.68 & -- & 765 & 6.7 & 140 \\
\hline D12 & 404744081582100 & $11-27-84$ & DGW & 1030 & 27.83 & -- & 830 & 6.7 & 150 \\
\hline 14 & 404758081585900 & $11-28-84$ & RGW & 1340 & 25.17 & - & 1240 & 7.3 & 130 \\
\hline 32 & 404854081591200 & $11-27-84$ & DSP & 1645 & -- & -- & 480 & 6.6 & -- \\
\hline CC AT USR & 404848081580900 & $11-27-84$ & SW & 1230 & -- & 3.7 & 440 & 8.4 & -- \\
\hline KBC AT SR & 404838081585200 & $11-27-84$ & SW & 1445 & -- & 30 & 595 & 7.9 & -. \\
\hline
\end{tabular}


Table 19. Water-quality records for ground-water and surface-water samples, Killbuck Creek valley near Wooster, Ohio-Continued

Sample 3: November 26-28, 1984-Continued

\begin{tabular}{|c|c|c|c|c|c|c|c|c|c|}
\hline $\begin{array}{l}\text { Local } \\
\text { identifier }\end{array}$ & Date & $\begin{array}{c}\text { Temper- } \\
\text { ature, } \\
\text { air, } \\
\text { (deg. C) }\end{array}$ & $\begin{array}{c}\text { Temper- } \\
\text { ature, } \\
\text { water } \\
\text { (deg. C) }\end{array}$ & $\begin{array}{c}\text { Oxygen, } \\
\text { dis- } \\
\text { eolved } \\
\text { (mgh) }\end{array}$ & $\begin{array}{l}\text { Oxygen, } \\
\text { dis- } \\
\text { solved } \\
\text { (percent } \\
\text { satur- } \\
\text { afion) } \\
\end{array}$ & $\begin{array}{l}\text { Hard- } \\
\text { ness, } \\
\text { totai } \\
\text { (mgll } \\
\text { as } \\
\mathrm{CaCO}_{3} \text { ) }\end{array}$ & $\begin{array}{l}\text { Caiclum, } \\
\text { dis- } \\
\text { eoived } \\
\text { (mg/ } \\
\text { as Ca) }\end{array}$ & $\begin{array}{l}\text { Magne- } \\
\text { sium, } \\
\text { dis- } \\
\text { eolved } \\
\text { (mg/L } \\
\text { as } \mathrm{Mg} \text { ) } \\
\end{array}$ & $\begin{array}{c}\text { Sodium, } \\
\text { dis- } \\
\text { solved } \\
\text { (mg/l } \\
\text { as Na) }\end{array}$ \\
\hline P4 & $11-28-84$ & 1.5 & 10.0 & $<0.1$ & -- & 310 & 94 & 19 & 19 \\
\hline P5 & $11-28-84$ & 1.5 & 10.0 & $<0.1$ & -- & 390 & 120 & 23 & 62 \\
\hline D2 & $11-28-84$ & 7.0 & 10.5 & $<0.1$ & -- & 320 & 95 & 20 & 23 \\
\hline S5 & $11-26-84$ & 17.0 & 11.5 & $<0.1$ & -- & 370 & 110 & 23 & 27 \\
\hline D6 & $11-26-84$ & 17.0 & 11.0 & $<0.1$ & -- & 240 & 67 & 18 & 11 \\
\hline$\$ 8$ & $11-26-84$ & 15.0 & 11.0 & $<0.1$ & -. & 240 & 72 & 15 & 14 \\
\hline D9 & $11-26-84$ & 17.5 & 11.0 & $<0.1$ & -- & 220 & 60 & 17 & 29 \\
\hline D10 & $11-27-84$ & 10.0 & 10.5 & $<0.1$ & -- & 330 & 100 & 19 & 27 \\
\hline D12 & $11-27-84$ & 10.0 & 9.0 & $<0.1$ & -- & 390 & 120 & 22 & 23 \\
\hline 14 & $11-28-84$ & 10.0 & 11.0 & $<0.1$ & -- & 250 & 65 & 21 & 150 \\
\hline 32 & $11-27-84$ & 15.5 & 12.0 & -- & -- & 200 & 55 & 16 & 15 \\
\hline CC AT USR & $11-27-84$ & 15.5 & 7.0 & 13.5 & 115 & 190 & 48 & 16 & 17 \\
\hline KBC AT SR & $11-27-84$ & 15.5 & 7.0 & 12.0 & 103 & 250 & 66 & 20 & 25 \\
\hline $\begin{array}{l}\text { Locai } \\
\text { Identifier } \\
\end{array}$ & Date & $\begin{array}{l}\text { Sodium, } \\
\text { percent }\end{array}$ & $\begin{array}{l}\text { Sodlum } \\
\text { ad- } \\
\text { sorp- } \\
\text { tlon } \\
\text { ratlo }\end{array}$ & $\begin{array}{l}\text { Potas- } \\
\text { elum, } \\
\text { dle- } \\
\text { solved } \\
\text { (mg/L } \\
\text { as } \mathrm{K} \text { ) }\end{array}$ & $\begin{array}{c}\text { Blcar- } \\
\text { bonate, } \\
\text { WH FET, } \\
\text { fieid } \\
\left(\mathrm{mg}^{\prime} \mathrm{las}\right. \\
\left.\mathrm{HCO}_{3}\right)\end{array}$ & $\begin{array}{c}\text { Alka- } \\
\text { iinity, } \\
\text { WH FET, } \\
\text { field } \\
\left(\mathrm{mg}_{\mathrm{L}} \text { as }\right. \\
\left.\mathrm{CaCO}_{3}\right)\end{array}$ & $\begin{array}{c}\text { Suifate, } \\
\text { dls- } \\
\text { solved } \\
\text { (mg/l } \\
\left.\text { ae } \mathrm{SO}_{4}\right)\end{array}$ & \multicolumn{2}{|c|}{$\begin{array}{l}\text { Chio- } \\
\text { ride, } \\
\text { dls- } \\
\text { eolved } \\
\text { (mg/L } \\
\text { as Cl) }\end{array}$} \\
\hline P4 & $11-28-84$ & 12 & 0.5 & 1.1 & 300 & 249 & 60 & & 51 \\
\hline P5 & $11-28-81$ & 25 & 1 & 1.8 & 380 & 315 & 78 & & 30 \\
\hline $\mathrm{D} 2$ & $11-28-84$ & 13 & 0.6 & 1.5 & 290 & 238 & 69 & & 62 \\
\hline S5 & $11-26-84$ & 14 & 0.6 & 1.3 & 360 & 297 & 77 & & 66 \\
\hline D6 & $11-26-84$ & 9 & 0.3 & 1.3 & 230 & 187 & 39 & & 42 \\
\hline S8 & $11-26-84$ & 11 & 0.4 & 2.1 & 220 & 180 & 43 & & 36 \\
\hline D9 & $11-26-84$ & 22 & 0.9 & 1.5 & 220 & 183 & 43 & & 61 \\
\hline D10 & $11-27-84$ & 15 & 0.6 & 1.3 & 340 & 282 & 56 & & 53 \\
\hline D12 & $11-27-84$ & 11 & 0.5 & 1.7 & 430 & 348 & 57 & & 48 \\
\hline 14 & $11-28-84$ & 56 & 4 & 2.6 & 250 & 205 & 6.6 & & 80 \\
\hline 32 & $11-27-84$ & 14 & 0.5 & 2.8 & 170 & 139 & 43 & & 39 \\
\hline CC AT USR & $11-27-84$ & 16 & 0.5 & 2.8 & 130 & 110 & 42 & & 39 \\
\hline KBC AT SR & $11-27-84$ & 18 & 0.7 & 1.7 & 190 & 158 & 78 & & 49 \\
\hline
\end{tabular}


Table 19. Water-quality records for ground-water and surface-water samples, Killbuck Creek valley near Wooster, Ohio-Continued

Sample 3: November 26-28, 1984-Continued

\begin{tabular}{|c|c|c|c|c|c|c|c|c|}
\hline $\begin{array}{l}\text { Locai } \\
\text { Identifier }\end{array}$ & Date & $\begin{array}{l}\text { Fluo- } \\
\text { rlde, } \\
\text { dis- } \\
\text { solved } \\
\text { (mgh } \\
\text { as F) } \\
\end{array}$ & $\begin{array}{c}\text { sillos, } \\
\text { dlis- } \\
\text { solved } \\
\text { (mg/L } \\
\text { as } \\
\mathrm{SIO}_{2} \text { ) }\end{array}$ & $\begin{array}{l}\text { Sollde, } \\
\text { residue } \\
\text { at } 180 \\
\text { deg. C, } \\
\text { dls- } \\
\text { solved } \\
\text { (mg/L) }\end{array}$ & $\begin{array}{c}\text { Sollids, } \\
\text { sum of } \\
\text { constl- } \\
\text { tuents, } \\
\text { dis- } \\
\text { solved } \\
\text { (mg/L) }\end{array}$ & $\begin{array}{c}\text { Sollde, } \\
\text { dls. } \\
\text { solved } \\
\text { (tons } \\
\text { por } \\
\text { day) } \\
\end{array}$ & $\begin{array}{l}\text { Alum- } \\
\text { Inum, } \\
\text { total } \\
\text { recov- } \\
\text { erable } \\
\text { (ugh } \\
\text { a Al) }\end{array}$ & $\begin{array}{c}\text { Aium- } \\
\text { Inum, } \\
\text { dls- } \\
\text { solved } \\
(\mu g / \\
\text { as Al) }\end{array}$ \\
\hline P4 & $11-28-84$ & $<0.1$ & 11 & 407 & 407 & -- & 30 & 30 \\
\hline P5 & $11-28-84$ & $<0.1$ & 14 & 618 & 621 & -- & 30 & 10 \\
\hline D2 & $11-28-84$ & $<0.1$ & 10 & 432 & 425 & -- & 100 & 20 \\
\hline S5 & $11-26-84$ & $<0.1$ & 19 & 540 & 503 & -- & 440 & 20 \\
\hline D6 & $11-26-84$ & $<0.1$ & 9.9 & 288 & 301 & -- & 130 & 30 \\
\hline S8 & $11-26-84$ & $<0.1$ & 8.8 & 343 & 299 & -- & 120 & 20 \\
\hline D9 & $11-26-84$ & 0.1 & 12 & 315 & 334 & -- & 1100 & 20 \\
\hline D10 & $11-27-84$ & $<0.1$ & 15 & 444 & 443 & -. & 90 & 10 \\
\hline D12 & $11-27-84$ & $<0.1$ & 12 & 529 & 495 & -- & 520 & 10 \\
\hline 14 & $11-28-84$ & 0.1 & 12 & 673 & 661 & -- & 50 & 10 \\
\hline 32 & $11-27-84$ & $<0.1$ & 6.0 & 261 & 260 & -- & 70 & 20 \\
\hline CC AT USR & $11-27-84$ & $<0.1$ & 3.2 & 245 & 234 & 2.45 & 40 & 30 \\
\hline KBC AT SR & $11-27-84$ & 0.1 & 5.3 & 371 & 340 & 30.1 & 90 & 30 \\
\hline $\begin{array}{l}\text { Local } \\
\text { Identifier }\end{array}$ & Date & $\begin{array}{l}\text { Iron, } \\
\text { total } \\
\text { recov- } \\
\text { erable } \\
(\mu \mathrm{g} / \mathrm{L} \\
\text { a } \mathrm{Fe})\end{array}$ & $\begin{array}{l}\text { Iron, } \\
\text { dls- } \\
\text { solved } \\
(\mu g / 2 \\
\text { as Fo) }\end{array}$ & $\begin{array}{c}\text { Manga- } \\
\text { nese, } \\
\text { total } \\
\text { recov- } \\
\text { erable } \\
(\mu g / 2 \\
\text { as Mn) }\end{array}$ & $\begin{array}{l}\text { Mangar } \\
\text { nese, } \\
\text { dls- } \\
\text { solved } \\
(\mu g / L \\
\text { as } \mathrm{Mn})\end{array}$ & $\begin{array}{l}\delta \mathrm{D}, \\
\text { per } \\
\text { mII }\end{array}$ & $\begin{array}{l}\delta^{180} \text {, } \\
\text { por } \\
\text { mll }\end{array}$ & $\begin{array}{c}\text { Tritium, } \\
\text { total } \\
\text { (pc//L) }\end{array}$ \\
\hline P4 & $11-28-84$ & 2300 & 2000 & 230 & 200 & -56.5 & -8.65 & -- \\
\hline P5 & $11-28-84$ & 3300 & 2900 & 240 & 220 & -55.5 & -8.60 & -. \\
\hline D2 & $11-28-84$ & 2100 & 1400 & 80 & 63 & -57.5 & -8.90 & 110 \\
\hline s5 & $11-26-84$ & 5000 & 1300 & 860 & 750 & -54.6 & -8.45 & 130 \\
\hline D6 & $11-26-84$ & 1500 & 760 & 70 & 35 & -54.5 & -8.60 & -- \\
\hline S8 & $11-26-84$ & 580 & 9 & 390 & 350 & -54.0 & -8.25 & -- \\
\hline D9 & $11-26-84$ & 15000 & 300 & 320 & 69 & -56.0 & -8.60 & .. \\
\hline D10 & $11-27-84$ & 2400 & 1800 & 440 & 420 & -54.5 & -8.55 & -- \\
\hline D12 & $11-27-84$ & 6500 & 2200 & 470 & 390 & -56.5 & -8.45 & -. \\
\hline 14 & $11-28-84$ & 620 & 470 & 120 & 99 & -57.0 & -8.65 & 64 \\
\hline 32 & $11-27-84$ & 110 & 9 & $<10$ & $<1$ & -56.0 & -8.50 & .- \\
\hline CC AT USR & $11-27-84$ & 80 & 13 & 30 & 10 & -54.5 & -8.40 & .. \\
\hline KBC AT SR & $11-27-84$ & 450 & 13 & 100 & 86 & -50.0 & -7.80 & -. \\
\hline
\end{tabular}


Table 19. Water-quality records for ground-water and surface-water samples, Killbuck Creek valley near Wooster, Ohio-Continued

Sample 4: January 15-18, 1985

\begin{tabular}{|c|c|c|c|c|c|c|c|c|c|c|}
\hline $\begin{array}{l}\text { Local } \\
\text { Identifier }\end{array}$ & \multicolumn{2}{|c|}{$\begin{array}{l}\text { Statlon } \\
\text { number }\end{array}$} & Date & $\begin{array}{c}\text { Typo } \\
\text { of } \\
\text { site }\end{array}$ & $\begin{array}{l}\text { Water } \\
\text { level } \\
\text { (feet) }\end{array}$ & $\begin{array}{l}\text { Spe- } \\
\text { ciflc } \\
\text { con- } \\
\text { duct- } \\
\text { ance } \\
(\mu S / c m)\end{array}$ & $\begin{array}{c}\text { pH } \\
\text { (stand- } \\
\text { ard } \\
\text { unlis) }\end{array}$ & $\begin{array}{c}\text { Eh } \\
\text { (mv) }\end{array}$ & $\begin{array}{c}\text { Temper- } \\
\text { ature, } \\
\text { alr } \\
\text { (deg. C) }\end{array}$ & $\begin{array}{l}\text { Temper- } \\
\text { ature, } \\
\text { water } \\
\text { (deg. C) }\end{array}$ \\
\hline P4 & \multicolumn{2}{|c|}{404801081583300} & $01-17-85$ & DGW & -- & 792 & 7.2 & -- & -9.0 & 10.5 \\
\hline P5 & \multicolumn{2}{|c|}{404800081583100} & $01-18-85$ & DGW & -- & 964 & 7.1 & 180 & -9.0 & 10.0 \\
\hline \$5 & \multicolumn{2}{|c|}{404800081584501} & $01-16-85$ & DGW & 23.03 & 832 & 7.1 & 180 & -9.0 & 11.0 \\
\hline D6 & \multicolumn{2}{|c|}{404839081590900} & $01-15-85$ & DGW & 5.20 & 491 & 7.7 & 80 & -2.0 & 10.5 \\
\hline S8 & \multicolumn{2}{|c|}{404805081582600} & $01-16-85$ & DGW & 26.36 & 595 & 7.2 & 310 & -9.0 & 11.0 \\
\hline D9 & \multicolumn{2}{|c|}{404805081582601} & $01-15-85$ & DGW & 31.84 & -. & 7.7 & 130 & -10.0 & 10.0 \\
\hline & \multicolumn{2}{|c|}{404758081585900} & 01-18-85 & RGW & 40 & 1230 & 7.7 & 140 & -9.0 & 11.0 \\
\hline CC AT USR & \multicolumn{2}{|c|}{404848081580900} & $01-17-85$ & SW & 30 & 456 & 8.0 & -- & -12.0 & 0.0 \\
\hline KBC AT SR & \multicolumn{2}{|c|}{404838081585200} & $01-17-85$ & SW & -- & 593 & 7.9 & -- & -12.0 & 0.5 \\
\hline $\begin{array}{l}\text { Local } \\
\text { Identifier }\end{array}$ & Date & $\begin{array}{c}\text { Oxygen, } \\
\text { dls- } \\
\text { solved } \\
\text { (mg/L) }\end{array}$ & $\begin{array}{l}\text { Oxygen, } \\
\text { dla- } \\
\text { solved } \\
\text { (percent } \\
\text { satur- } \\
\text { ation) }\end{array}$ & $\begin{array}{c}\text { Hard- } \\
\text { neas, } \\
\text { total } \\
(\mathrm{mg} / \mathrm{L} \\
\mathrm{as} \\
\left.\mathrm{CaCO}_{3}\right)\end{array}$ & $\begin{array}{l}\text { Caiclum, } \\
\text { dle- } \\
\text { solved } \\
\text { (mg/L } \\
\text { as Ca) }\end{array}$ & $\begin{array}{l}\text { Magne- } \\
\text { slum, } \\
\text { dle- } \\
\text { solved } \\
\text { (mg/L } \\
\text { as Mg) }\end{array}$ & $\begin{array}{l}\text { Sodlum, } \\
\text { dle- } \\
\text { solved } \\
\text { (mg/l } \\
\text { as } \mathrm{Na} \text { ) }\end{array}$ & $\begin{array}{l}\text { Sodium, } \\
\text { percent }\end{array}$ & $\begin{array}{c}\text { Sodlum } \\
\text { ad- } \\
\text { sorp- } \\
\text { tlon } \\
\text { ratlo }\end{array}$ & $\begin{array}{c}\text { Potas- } \\
\text { slum, } \\
\text { dlis- } \\
\text { solved } \\
\text { (mg/L } \\
\text { as } \mathrm{K}) \\
\end{array}$ \\
\hline P4 & $01-17-85$ & 0.3 & 3 & -- & -- & -- & -- & -- & -- & -- \\
\hline P5 & $01-18-85$ & 0.3 & 3 & 390 & 120 & 23 & 51 & 22 & 1 & 1.7 \\
\hline S5 & $01-16-85$ & 0.2 & 2 & -- & -- & -- & -- & -- & -- & -- \\
\hline D6 & $01-15-85$ & 0.3 & 3 & 240 & 67 & 18 & 11 & 9 & 0.3 & 1.3 \\
\hline S8 & $01-16-85$ & 0.4 & 4 & -- & -- & - & - & -- & -- & -- \\
\hline D9 & $01-15-85$ & 0.2 & -- & 230 & 62 & 18 & 34 & 24 & 1 & 1.6 \\
\hline 14 & $01-18-85$ & 0.1 & 1 & 260 & 68 & 22 & 140 & 54 & 4 & 2.8 \\
\hline CC AT USR & $01-17-85$ & 13.0 & 94 & 190 & 48 & 16 & 17 & 16 & 0.5 & 2.5 \\
\hline KBC AT SR & $01-17-85$ & 12.4 & 91 & 260 & 70 & 20 & 22 & 15 & 0.6 & 3.5 \\
\hline $\begin{array}{l}\text { Local } \\
\text { Identifier }\end{array}$ & Date & $\begin{array}{c}\text { Blcar- } \\
\text { bonate, } \\
\text { WH FET, } \\
\text { fleld } \\
\text { (mg/l as } \\
\left.\mathrm{HCO}_{3}\right)\end{array}$ & $\begin{array}{c}\text { Alka- } \\
\text { Ilnity, } \\
\text { WH FET, } \\
\text { field } \\
(\mathrm{mg} / \mathrm{L} \text { as } \\
\left.\mathrm{CaCO}_{3}\right) \\
\end{array}$ & $\begin{array}{c}\text { Sulfide, } \\
\text { total } \\
\text { (mg/L } \\
\text { as S) }\end{array}$ & $\begin{array}{c}\text { Sulfats, } \\
\text { dle- } \\
\text { solved } \\
(\mathrm{mg} / \mathrm{L} \\
\left.\mathrm{as} \mathrm{SO}_{4}\right)\end{array}$ & $\begin{array}{l}\text { Chio- } \\
\text { ride, } \\
\text { dis- } \\
\text { solved } \\
\text { (mg/L } \\
\text { as Cl) }\end{array}$ & $\begin{array}{l}\text { Fluo- } \\
\text { rlde, } \\
\text { dle- } \\
\text { solved } \\
\text { (mg/l } \\
\text { as F) }\end{array}$ & $\begin{array}{c}\text { Sillca, } \\
\text { dls- } \\
\text { solved } \\
\text { (mg/L } \\
\text { as } \\
\mathrm{SiO}_{2} \text { ) }\end{array}$ & $\begin{array}{c}\text { Sollds, } \\
\text { residue } \\
\text { at } 180 \\
\text { deg. C, } \\
\text { dle- } \\
\text { solved } \\
\text { (mg/L) } \\
\end{array}$ & $\begin{array}{c}\text { Sollds, } \\
\text { sum of } \\
\text { constl- } \\
\text { tuents, } \\
\text { dls- } \\
\text { solved } \\
\text { (mg/L) }\end{array}$ \\
\hline P4 & $01-17-85$ & -- & -- & -- & -- & -- & -- & -- & -- & - \\
\hline P5 & $01-18.85$ & -- & -- & - & 74 & 100 & 0.1 & 14 & 586 & 515 \\
\hline S5 & $01-16-85$ & -. & -- & $<0.5$ & -- & -- & -- & -- & -- & -- \\
\hline D6 & $01-15-85$ & 230 & 187 & -- & 35 & 35 & 0.1 & 9.9 & 273 & 290 \\
\hline 58 & $01-16-85$ & -- & -- & -- & - & - & - & -- & -- & $\cdots$ \\
\hline D9 & $01-15-85$ & 220 & 180 & -- & 41 & 66 & 0.1 & 12 & 304 & 343 \\
\hline 14 & $01-18-85$ & -- & - & $<0.5$ & 7.1 & 260 & 0.2 & 12 & 618 & 613 \\
\hline CC AT USR & $01-17-85$ & 130 & 103 & -- & 38 & 46 & 0.1 & 6.2 & 252 & 236 \\
\hline KBC AT SR & $01-17-85$ & 200 & 167 & -- & 71 & 45 & 0.2 & 6.6 & 352 & 339 \\
\hline
\end{tabular}


Table 19. Water-quality records for ground-water and surface-water samples, Killbuck Creek valley near Wooster, Ohio-Continued

Sample 4: January 15-18, 1985-Continned

\begin{tabular}{|c|c|c|c|c|c|c|c|c|c|c|}
\hline $\begin{array}{l}\text { Local } \\
\text { Identifier }\end{array}$ & Date & $\begin{array}{l}\text { Alum- } \\
\text { Inum, } \\
\text { total } \\
\text { recov- } \\
\text { erable } \\
(\mu g / L \\
\text { as Al) }\end{array}$ & $\begin{array}{l}\text { Alum- } \\
\text { Inum, } \\
\text { dls- } \\
\text { solved } \\
\text { ( } \mu \mathrm{g} / \mathrm{L} \\
\text { as Al) }\end{array}$ & $\begin{array}{l}\text { Iron, } \\
\text { total } \\
\text { recov- } \\
\text { erable } \\
(\mu g h \text {. } \\
\text { e Fe) }\end{array}$ & 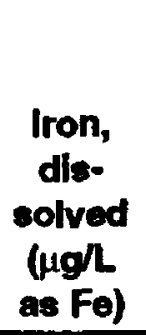 & 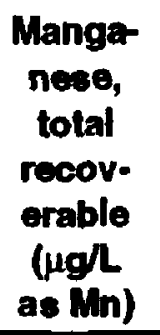 & $\begin{array}{l}\text { Manga- } \\
\text { nese, } \\
\text { dls- } \\
\text { solved } \\
\text { ( } \mu g / L \\
\text { as Mn) }\end{array}$ & $\begin{array}{l}\text { 6D, } \\
\text { por } \\
\text { mll }\end{array}$ & $\begin{array}{c}\delta^{18} \mathrm{o} \\
\text { por } \\
\mathrm{mll}\end{array}$ & $\begin{array}{c}\text { Trtium, } \\
\text { total } \\
\text { (pollL) }\end{array}$ \\
\hline P4 & $01-17-85$ & - & .- & -- & -- & - & .- & -56.0 & -8.50 & - \\
\hline P5 & $01-18-85$ & 10 & $<10$ & 3100 & 2800 & 290 & 260 & -57.0 & -8.55 & 140 \\
\hline S5 & $01-16-85$ & -- & $-\infty$ & -- & -. & -- & -- & -56.0 & -8.50 & 120 \\
\hline D6 & $01-15-85$ & 90 & 10 & 2200 & 730 & 70 & 34 & -56.5 & -8.50 & 120 \\
\hline S8 & $01-16-85$ & -- & -. & -. & - & - & -- & -51.5 & -8.20 & -. \\
\hline D9 & $01-15-85$ & 380 & 20 & 2500 & 310 & 100 & 68 & -60.5 & -8.55 & - \\
\hline 14 & $01-18-85$ & 80 & $<10$ & 890 & 390 & 120 & 100 & -58.5 & -8.65 & 65 \\
\hline CC AT USR & $01-17-85$ & 40 & 10 & 50 & 11 & 10 & 16 & -55.5 & -8.60 & 100 \\
\hline KBC AT SR & $01-17-85$ & 240 & $<10$ & 430 & 19 & 110 & 85 & -54.0 & -8.30 & 110 \\
\hline
\end{tabular}

Sample 5a: February 21-22, 1985-before flooding

\begin{tabular}{|c|c|c|c|c|c|c|c|c|c|c|}
\hline $\begin{array}{l}\text { Locel } \\
\text { Identifier }\end{array}$ & $\begin{array}{l}\text { Station } \\
\text { number }\end{array}$ & Date & $\begin{array}{c}\text { Type } \\
\text { of } \\
\text { elte }\end{array}$ & $\pi m e$ & $\begin{array}{l}\text { Water } \\
\text { level } \\
\text { (feet) }\end{array}$ & $\begin{array}{l}\text { Spe- } \\
\text { ciflc } \\
\text { con- } \\
\text { duct- } \\
\text { ance } \\
\text { (uS/cm) }\end{array}$ & $\begin{array}{c}\text { pH } \\
\text { (atand- } \\
\text { ard } \\
\text { unlto) }\end{array}$ & $\begin{array}{c}\text { Eh } \\
\text { (mv) }\end{array}$ & $\begin{array}{c}\text { Tempor- } \\
\text { ature, } \\
\text { alr } \\
\text { (deg. C) }\end{array}$ & $\begin{array}{c}\text { Temper- } \\
\text { ature, } \\
\text { water } \\
\text { (deg. C) }\end{array}$ \\
\hline P4 & 404801081583300 & $02-22-85$ & DGW & 0820 & 51.50 & 710 & 7.1 & 160 & -- & 10.5 \\
\hline P5 & 404800081583100 & $02-22-85$ & DGW & 0900 & 40.15 & 1150 & 7.0 & 170 & 1.5 & 10.0 \\
\hline D6 & 404839081590900 & $02-22-85$ & DGW & 1250 & 5.49 & 530 & 7.7 & 80 & 1.5 & 10.5 \\
\hline S8 & 404805081582600 & $02-22-85$ & DGW & 1130 & 27.67 & 660 & 7.1 & 280 & 1.5 & 10.5 \\
\hline D9 & 404805081582601 & $02-22-85$ & DGW & 1037 & 33.98 & 615 & 7.6 & 80 & 1.5 & 10.5 \\
\hline D10 & 404752081583400 & $02-21-85$ & DGW & 1515 & 33.96 & 757 & 7.2 & 200 & 1.5 & 10.5 \\
\hline D12 & 404744081582100 & $02-21-85$ & DGW & 1635 & 29.21 & 865 & 7.0 & 200 & 1.5 & 10.0 \\
\hline 14 & 404758081585900 & $02-21-85$ & RGW & 1330 & -- & 1220 & 7.7 & -- & 1.5 & 11.0 \\
\hline 32 & 404854081591200 & $02-21-85$ & DSP & 1130 & -- & 488 & 7.0 & 400 & 1.5 & 8.0 \\
\hline CC AT USR & 404848081580900 & $02-21-85$ & SW & 1030 &.- & 502 & 8.0 & -- & 1.5 & 0.5 \\
\hline KBC AT SR & 404838081585200 & $02-21-85$ & SW & 0920 & -- & 725 & 7.6 & -- & 1.5 & 0.0 \\
\hline
\end{tabular}


Table 19. Water-quality records for ground-water and surface-water samples, Killbuck Creek valley near Wooster, Ohio-Continued

Sample 5a: February 21-22, 1985-before flooding-Continued

\begin{tabular}{|c|c|c|c|c|c|c|c|c|c|c|}
\hline $\begin{array}{l}\text { Local } \\
\text { Identifier }\end{array}$ & Date & $\begin{array}{c}\text { Oxygen, } \\
\text { dis- } \\
\text { solved } \\
\text { (mg/L) }\end{array}$ & $\begin{array}{c}\text { Oxygen, } \\
\text { dis- } \\
\text { solved } \\
\text { (percent } \\
\text { satur- } \\
\text { atlon) } \\
\end{array}$ & $\begin{array}{c}\text { Hard- } \\
\text { ness, } \\
\text { total } \\
(\mathrm{mg} / \mathrm{L} \\
\text { as } \\
\left.\mathrm{CaCO}_{3}\right) \\
\end{array}$ & $\begin{array}{c}\text { Caiclum, } \\
\text { dis- } \\
\text { solved } \\
\text { (mg/L } \\
\text { as Ca) } \\
\end{array}$ & $\begin{array}{l}\text { Magne- } \\
\text { slum, } \\
\text { dls- } \\
\text { solved } \\
(\mathrm{mg} / \mathrm{L} \\
\text { as Mg) } \\
\end{array}$ & $\begin{array}{l}\text { Sodium, } \\
\text { dis: } \\
\text { soived } \\
\text { (mg/L } \\
\text { as } \mathrm{Na}) \\
\end{array}$ & $\begin{array}{l}\text { Sodium, } \\
\text { percent }\end{array}$ & $\begin{array}{c}\text { Sodium } \\
\text { ad- } \\
\text { sorp- } \\
\text { tion } \\
\text { ratio } \\
\end{array}$ & $\begin{array}{c}\text { Polas- } \\
\text { sium, } \\
\text { dls- } \\
\text { solved } \\
\text { (mg/L } \\
\text { as K) } \\
\end{array}$ \\
\hline P4 & $02-22-85$ & 0.1 & 1 & 320 & 97 & 20 & 21 & 12 & 0.5 & 1.5 \\
\hline P5 & $02-22-85$ & 0.1 & 1 & -- & -- & -- & -- & -- & -- & -- \\
\hline D6 & $02-22-85$ & $<0.1$ & -- & -- & -. & -- & -- & -- & -- & -- \\
\hline S8 & $02-22-85$ & 0.2 & 2 & -- & -- & -- & -- & -- & -- & -- \\
\hline D9 & $02-22-85$ & 0.3 & 3 & -- & -- & -- & -- & -- & -- & -- \\
\hline D10 & $02-21-85$ & 0.3 & 3 & 330 & 100 & 19 & 27 & 15 & 0.6 & 1.2 \\
\hline D12 & $02-21-85$ & 0.2 & 2 & 420 & 130 & 23 & 25 & 11 & 0.5 & 1.8 \\
\hline 14 & $02-21-85$ & 0.2 & 2 & -- & -- & - & -- & -- & -- & -- \\
\hline 32 & $02-21-85$ & 6.0 & 53 & 210 & 58 & 17 & 14 & 12 & 0.4 & 2.7 \\
\hline CC AT USR & $02-21-85$ & 13.6 & 99 & -- & -- & -- & -- & -- & $-\cdot$ & -- \\
\hline KBC AT SR & $02-21-85$ & 12.7 & 91 & -- & -- & -. & -- & -- & -- & -. \\
\hline
\end{tabular}

\begin{tabular}{|c|c|c|c|c|c|c|c|c|c|}
\hline $\begin{array}{l}\text { Local } \\
\text { Identifier }\end{array}$ & Date & $\begin{array}{c}\text { Bicar. } \\
\text { bonate, } \\
\text { WH FET, } \\
\text { field } \\
\left(\mathrm{mg}^{2} \mathrm{~L} \text { as }\right. \\
\left.\mathrm{HCO}_{3}\right)\end{array}$ & $\begin{array}{c}\text { Alka- } \\
\text { linity, } \\
\text { WH FET, } \\
\text { fleld } \\
\left(\mathrm{mgll}^{2} \text { as }\right. \\
\left.\mathrm{CaCO}_{3}\right)\end{array}$ & $\begin{array}{l}\text { Sulfate, } \\
\text { dis- } \\
\text { solved } \\
\text { (mg/L } \\
\text { as } \mathrm{sO}_{4} \text { ) }\end{array}$ & $\begin{array}{l}\text { Chlo- } \\
\text { ride, } \\
\text { dis- } \\
\text { solved } \\
\text { (mghl } \\
\text { as Cl) }\end{array}$ & $\begin{array}{l}\text { Fluo- } \\
\text { ride, } \\
\text { dls- } \\
\text { solved } \\
\text { (mgh } \\
\text { as F) }\end{array}$ & $\begin{array}{c}\text { Silica, } \\
\text { dis- } \\
\text { soived } \\
\text { (mg/l } \\
\text { as } \\
\mathrm{siO}_{2} \text { ) }\end{array}$ & $\begin{array}{l}\text { Solids, } \\
\text { residue } \\
\text { st } 180 \\
\text { deg. C, } \\
\text { dis- } \\
\text { solved } \\
\text { (mg/L) }\end{array}$ & $\begin{array}{c}\text { Sollds, } \\
\text { sum of } \\
\text { constl- } \\
\text { tuents, } \\
\text { dis- } \\
\text { solved } \\
\text { (mg/L) }\end{array}$ \\
\hline P4 & $02-22-85$ & 280 & 233 & 64 & 53 & $<0.1$ & 12 & 413 & 410 \\
\hline P5 & $02-22-85$ & -- & -- & -- & .- & .. & -- & -- & -. \\
\hline D6 & $02-22-85$ & -- & -- & -- & .- & -- & -- & -- & -. \\
\hline 58 & $02-22-85$ & .. & -. & -- & -- & .. & -- & -- & -- \\
\hline D9 & $02-22-85$ & -- & -- & .- & -- & -- & -- & -- & -- \\
\hline D10 & $02-21-85$ & 330 & 269 & 55 & 54 & $<0.1$ & 14 & 424 & 434 \\
\hline D12 & $02-21-85$ & 420 & 345 & 60 & 51 & $<0.1$ & 12 & 511 & 512 \\
\hline 14 & $02-21-85$ & -- & .. & .- & -. & -- & -- & -- & -- \\
\hline 32 & $02-21-85$ & 170 & 136 & 47 & 37 & $<0.1$ & 5.6 & 278 & 263 \\
\hline CC AT USR & $02-21-85$ & -- & -- & -. & -- & -- & -- & -- & -- \\
\hline KBC AT SR & $02-21-85$ & -- & .. & -- & -- & -- & -- & -- & -- \\
\hline
\end{tabular}


Table 19. Water-quality records for ground-water and surface-water samples, Killbuck Creek valley near Wooster, Ohio-Continued

Sample 5a: February 21-22, 1985-before flooding-Continued

\begin{tabular}{|c|c|c|c|c|c|c|c|c|c|}
\hline $\begin{array}{l}\text { Locai } \\
\text { Identifier }\end{array}$ & Date & $\begin{array}{l}\text { Alum- } \\
\text { inum, } \\
\text { lotal } \\
\text { recov- } \\
\text { orable } \\
(\mu g / 2 \\
\text { as Al) }\end{array}$ & $\begin{array}{l}\text { Alum- } \\
\text { inum, } \\
\text { dls- } \\
\text { solved } \\
\text { ( } \mu \mathrm{g} / \mathrm{L} \\
\text { as Al) }\end{array}$ & 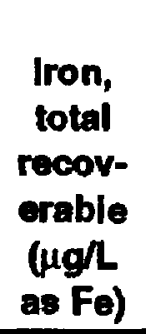 & $\begin{array}{l}\text { iron, } \\
\text { dle- } \\
\text { solved } \\
\text { (ug/L } \\
\text { as Fo) }\end{array}$ & $\begin{array}{l}\text { Manga- } \\
\text { nese, } \\
\text { total } \\
\text { recov- } \\
\text { erable } \\
\text { ( } \mu g / 2 \\
\text { as Mn) }\end{array}$ & 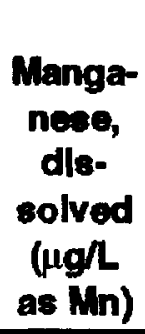 & $\begin{array}{l}\mathbf{8 D}, \\
\text { per } \\
\text { mil }\end{array}$ & $\begin{array}{c}\delta^{10} \mathrm{O} \\
\text { por } \\
\text { mil }\end{array}$ \\
\hline P4 & $02-22-85$ & 10 & $<10$ & 2800 & 2100 & 200 & 190 & -53.5 & -8.45 \\
\hline P5 & $02-22-85$ & -- & -- & -- & -- & -- & -- & -54.5 & -8.50 \\
\hline D6 & $02-22-85$ & -- & $\ldots$ & -- & -- & -- & -- & -55.5 & -8.50 \\
\hline S8 & $02-22-85$ & -- & - & -- & -- & -- & -- & -52.0 & -8.20 \\
\hline D9 & $02-22-85$ & -- & $=-$ & -- & - & - & -- & -54.5 & -8.50 \\
\hline D10 & $02-21-85$ & 120 & 10 & 3300 & 1700 & 400 & 390 & -54.5 & -8.40 \\
\hline $\mathrm{D} 12$ & $02-21-85$ & 440 & 10 & 6400 & 2200 & 480 & 440 & -52.5 & -7.75 \\
\hline 14 & $02-21-85$ & -. & -- & -- & -- & -- & -- & -55.0 & -8.60 \\
\hline 32 & $02-21-85$ & 440 & 10 & 1400 & 6 & 30 & $<1$ & -53.5 & -8.30 \\
\hline CC AT USR & $02-21-85$ & -. & - & -- & -- & - & -- & -58.0 & -8.90 \\
\hline KBC AT SR & $02-21-85$ & -. & - & -- & -- & -- & -- & -56.0 & -8.70 \\
\hline
\end{tabular}

Sample 5b: February 23, 1985-flood

\begin{tabular}{|c|c|c|c|c|c|c|c|c|}
\hline $\begin{array}{l}\text { Local } \\
\text { identifier }\end{array}$ & $\begin{array}{l}\text { Station } \\
\text { number }\end{array}$ & Date & $\begin{array}{l}\text { Type } \\
\text { of } \\
\text { Site }\end{array}$ & Time & $\begin{array}{l}\text { Spe- } \\
\text { cifle } \\
\text { con- } \\
\text { duct- } \\
\text { ance } \\
(\mu S / c m)\end{array}$ & $\begin{array}{c}\text { Temper- } \\
\text { ature, } \\
\text { water } \\
\text { (deg. C) }\end{array}$ & $\begin{array}{l}\text { 8D, } \\
\text { per } \\
\text { mil }\end{array}$ & $\begin{array}{c}\delta^{18} \mathrm{O} \\
\mathrm{per} \\
\mathrm{mil}\end{array}$ \\
\hline CC AT USR & 404848081580900 & $02-23-85$ & SW & 1420 & 250 & 1.0 & -81.0 & -12.10 \\
\hline KBC AT SR & 404838081585200 & $02-23-85$ & SW & 1345 & 285 & 1.0 & -80.0 & -11.90 \\
\hline KBC AT OMR & 03138800 & $02-23-85$ & SW & 1245 & 275 & 0.5 & -78.5 & -11.80 \\
\hline
\end{tabular}

Sample 5c: February 25-26, 1985-nood recession

\begin{tabular}{|c|c|c|c|c|c|c|c|c|c|}
\hline $\begin{array}{l}\text { Locai } \\
\text { identifier }\end{array}$ & $\begin{array}{l}\text { Statlon } \\
\text { number }\end{array}$ & Date & $\begin{array}{c}\text { Type } \\
\text { of } \\
\text { site }\end{array}$ & Time & $\begin{array}{l}\text { Water } \\
\text { level } \\
\text { (foet) }\end{array}$ & $\begin{array}{l}\text { Spe- } \\
\text { ciflc } \\
\text { con- } \\
\text { duct- } \\
\text { ance } \\
\text { ( } \mu \text { S/cm) }\end{array}$ & $\begin{array}{c}\text { pH } \\
\text { (stand- } \\
\text { ard } \\
\text { units) }\end{array}$ & $\begin{array}{c}\text { Eh } \\
(\mathbf{m v})\end{array}$ & $\begin{array}{c}\text { Temper- } \\
\text { ature, } \\
\text { water } \\
\text { (deg. C) }\end{array}$ \\
\hline P3 & 404802081583400 & $02-26-85$ & DGW & 0920 & -- & -- & - & -- & -- \\
\hline P4 & 404801081583300 & $02-26-85$ & DGW & 0915 & -- & -- & -- & -- & - \\
\hline P6 & 404759081583000 & $02-26-85$ & DGW & 0930 & -- & -- & -- & -- & -- \\
\hline $\mathrm{D} 2$ & 404802081583102 & $02-26-85$ & DGW & 0935 & 29.45 & 1310 & 7.1 & 170 & 10.0 \\
\hline S3 & 404802081583103 & $02-26-85$ & DGW & 1115 & 24.70 & 3140 & 6.5 & 320 & 11.0 \\
\hline
\end{tabular}


Table 19. Water-quality records for ground-water and surface-water samples, Killbuck Creek valley near Wooster, Ohio-Continued

Sample 5c: February 25-26, 1985-nlood recession-Continued

\begin{tabular}{|c|c|c|c|c|c|c|c|c|c|}
\hline $\begin{array}{l}\text { Locai } \\
\text { Identifier }\end{array}$ & $\begin{array}{l}\text { Statlon } \\
\text { number }\end{array}$ & Date & $\begin{array}{c}\text { Type } \\
\text { of } \\
\text { site } \\
\end{array}$ & Time & $\begin{array}{l}\text { Water } \\
\text { level } \\
\text { (feet) }\end{array}$ & $\begin{array}{l}\text { Spe- } \\
\text { cifle } \\
\text { con- } \\
\text { duct- } \\
\text { ance } \\
(\mu S / c m)\end{array}$ & $\begin{array}{c}\text { pH } \\
\text { (stand- } \\
\text { ard } \\
\text { units) }\end{array}$ & $\begin{array}{c}\text { Eh } \\
(\mathbf{m v})\end{array}$ & $\begin{array}{c}\text { Temper- } \\
\text { ature, } \\
\text { water } \\
\text { (deg. C) }\end{array}$ \\
\hline D4 & 404800081584500 & $02-25-85$ & DGW & 1720 & 21.77 & 890 & 7.5 & 120 & 11.0 \\
\hline S5 & 404800081584501 & $02-25-85$ & DGW & 1610 & 21.82 & 900 & 7.0 & 160 & 10.5 \\
\hline S8 & 404805081582600 & $02-26-85$ & DGW & 1400 & 25.06 & 910 & -- & -- & 10.5 \\
\hline D9 & 404805081582601 & $02-26-85$ & DGW & 1430 & 26.55 & 630 & -- & -- & 10.5 \\
\hline 17 & 404759081582100 & $02-25-85$ & DGW & 1435 & -- & 1630 & 7.1 & -- & -- \\
\hline KBC AT SR & 404838081585200 & $02-26-85$ & SW & 1500 & -- & -- & -- & -- & -- \\
\hline
\end{tabular}

\begin{tabular}{|c|c|c|c|c|c|c|c|c|c|}
\hline $\begin{array}{l}\text { Local } \\
\text { Identifier }\end{array}$ & Date & $\begin{array}{l}\text { Oxygen, } \\
\text { dls- } \\
\text { solved } \\
\text { (mg/L) }\end{array}$ & $\begin{array}{l}\text { Oxygen, } \\
\text { dlis- } \\
\text { solved- } \\
\text { (percent } \\
\text { satur- } \\
\text { ation) }\end{array}$ & $\begin{array}{c}\text { Hard- } \\
\text { ness, } \\
\text { total } \\
\text { (mg/L } \\
\text { as } \\
\left.\mathrm{CaCO}_{3}\right)\end{array}$ & $\begin{array}{l}\text { Calcium, } \\
\text { dis- } \\
\text { solved } \\
\text { (mg/l } \\
\text { as Ca) }\end{array}$ & $\begin{array}{l}\text { Magne- } \\
\text { slum, } \\
\text { dle- } \\
\text { solved } \\
\text { (mg/L } \\
\text { as Mg) }\end{array}$ & $\begin{array}{l}\text { Sodium, } \\
\text { dls- } \\
\text { soived } \\
\text { (mg/L } \\
\text { as Na) }\end{array}$ & $\begin{array}{l}\text { Sodlum, } \\
\text { percent }\end{array}$ & $\begin{array}{l}\text { Sodium } \\
\text { ad- } \\
\text { sorp- } \\
\text { tion } \\
\text { ratlo }\end{array}$ \\
\hline
\end{tabular}

\begin{tabular}{|c|c|c|c|c|c|c|c|c|c|}
\hline P3 & $02-26-85$ & - &.- & -- & -- & -- & -- & -- & -- \\
\hline P4 & $02-26-85$ & - & -- & -- & -- & -- & -- & -- & -- \\
\hline P6 & $02-26-85$ & -- & -- & -- & -- & -- & -- & -- & -- \\
\hline D2 & $02-26-85$ & 0.1 & 1 & 460 & 140 & 28 & 89 & 29 & 2 \\
\hline S3 & $02-26-85$ & 0.5 & 5 & 2300 & 580 & 210 & 20 & 2 & 0.2 \\
\hline D4 & $02-25-85$ & 0.4 & 4 & 360 & 97 & 29 & 46 & 22 & 1 \\
\hline S5 & $02-25-85$ & 0.2 & 2 & -- & -- & -- & -- & - & -- \\
\hline S8 & $02-26-85$ & $<0.1$ & -- & -- & -- & -- & -- & -- & -- \\
\hline D9 & $02-26-85$ & -- & -- & -- & .. & -- & -- & -- & -- \\
\hline 17 & $02-25-85$ & 0.1 & $\cdots$ & 430 & 130 & 26 & 150 & 43 & 3 \\
\hline
\end{tabular}

KBC AT SR $\quad 02-26-85$

\begin{tabular}{|c|c|c|c|c|c|c|c|c|c|}
\hline $\begin{array}{l}\text { Local } \\
\text { Identifier }\end{array}$ & Dats & $\begin{array}{l}\text { Potas- } \\
\text { sium, } \\
\text { dis- } \\
\text { solved } \\
\text { (mg/L } \\
\text { as K) }\end{array}$ & $\begin{array}{l}\text { Sulfate, } \\
\text { dls- } \\
\text { solved } \\
\text { (mg/L } \\
\text { as } \mathrm{SO}_{4} \text { ) }\end{array}$ & $\begin{array}{l}\text { Chio- } \\
\text { ride, } \\
\text { dis- } \\
\text { soived } \\
\text { (mgll } \\
\text { as Ci) }\end{array}$ & $\begin{array}{l}\text { Fluo- } \\
\text { ride, } \\
\text { dis- } \\
\text { solved } \\
\text { (mg/L } \\
\text { as F) }\end{array}$ & $\begin{array}{c}\text { Sillca, } \\
\text { dis- } \\
\text { solved } \\
\text { (mgh } \\
\text { as } \\
\mathrm{SiO}_{2} \text { ) }\end{array}$ & $\begin{array}{c}\text { Solids, } \\
\text { residue } \\
\text { at } 180 \\
\text { deg. C, } \\
\text { dlis- } \\
\text { solved } \\
\text { (mg/l) }\end{array}$ & $\begin{array}{c}\text { Sollds, } \\
\text { sum of } \\
\text { consti- } \\
\text { tuents, } \\
\text { dls- } \\
\text { solved } \\
\text { (mgh) }\end{array}$ & $\begin{array}{l}\text { Alum- } \\
\text { inum, } \\
\text { total } \\
\text { recov- } \\
\text { erable } \\
\text { ( } \mu \mathrm{g} / \mathrm{L} \\
\text { as AI) }\end{array}$ \\
\hline P3 & $02-26-85$ & -- & -- & -- & -- & -- & -- & -- & - \\
\hline P4 & $02-26-85$ & -- & -- & -- & -. & -- & -- & -- & -- \\
\hline P6 & $02-26-85$ & -. & -- & -- & -- & -- & -- & -- & - \\
\hline D2 & $02-26-85$ & 2.1 & 90 & 240 & $<0.1$ & 12 & 690 & 741 & 500 \\
\hline S3 & $02-26-85$ & 16 & 2000 & 41 & $<0.1$ & 5.5 & 3230 & 3070 & 60 \\
\hline
\end{tabular}


Table 19. Water-quality records for ground-water and surface-water samples, Killbuck Creek valley near Wooster, Ohio-Continued

Sample 5c: February 25-26, 1985-nood recession-Continued

\begin{tabular}{|c|c|c|c|c|c|c|c|c|c|c|}
\hline $\begin{array}{l}\text { Local } \\
\text { Identifier }\end{array}$ & Dats & $\begin{array}{l}\text { Potas- } \\
\text { slum, } \\
\text { dls- } \\
\text { solved } \\
\text { (mg/L } \\
\text { as K) }\end{array}$ & $\begin{array}{c}\text { Sulfate, } \\
\text { dis- } \\
\text { solved } \\
(\mathrm{mg} / \mathrm{h} \\
\left.\mathrm{as} \mathrm{SO}_{4}\right)\end{array}$ & $\begin{array}{l}\text { Ch! } \\
\text { rld } \\
\text { dls } \\
\text { solv } \\
\text { (mo } \\
\text { as }\end{array}$ & & $\begin{array}{l}\text { uo- } \\
\text { de, } \\
\text { ls- } \\
\text { ived } \\
\text { g/h } \\
\text { F) }\end{array}$ & $\begin{array}{l}\text { Sllica, } \\
\text { dls- } \\
\text { solved } \\
(\mathbf{m g} / \mathrm{L} \\
\text { as } \\
\left.\mathrm{SIO}_{2}\right)\end{array}$ & $\begin{array}{c}\text { Sollds, } \\
\text { residue } \\
\text { ot } 180 \\
\text { deg. C, } \\
\text { dls- } \\
\text { solved } \\
\text { (mgh) }\end{array}$ & $\begin{array}{c}\text { Sollds, } \\
\text { sum of } \\
\text { consti- } \\
\text { tuents, } \\
\text { dls- } \\
\text { solved } \\
\text { (mgll) }\end{array}$ & $\begin{array}{l}\text { Alum- } \\
\text { Inum, } \\
\text { total } \\
\text { recov- } \\
\text { erable } \\
(\mu g / L \\
\text { as Al) }\end{array}$ \\
\hline D4 & $02-25-85$ & 2.0 & 87 & 8 & & 0.1 & 13 & 499 & 493 & 480 \\
\hline S5 & $02-25-85$ & -- & - & & - & - & - & -- & -- & -- \\
\hline S8 & $02-26-85$ & -- & -- & & - & - & -- & -- & -- & -- \\
\hline D9 & $02-26-85$ & -- & -- & & - & - & -- & -- & -- & -- \\
\hline 17 & $02-25-85$ & 2.1 & 110 & 27 & & 0.1 & 15 & 854 & 872 & 20 \\
\hline KBC AT SR & $02-26-85$ & - & $\ldots$ & & - & - & -- & -- & - & -- \\
\hline $\begin{array}{l}\text { Local } \\
\text { Identifier }\end{array}$ & Dale & $\begin{array}{l}\text { Alum- } \\
\text { Inum, } \\
\text { dls- } \\
\text { solved } \\
\text { ( } \mu \mathrm{g} / \mathrm{h} \\
\text { as Al) }\end{array}$ & $\begin{array}{l}\text { Iron, } \\
\text { total } \\
\text { recov. } \\
\text { erable } \\
\text { ( } \mu \mathrm{g} / \mathrm{l} \\
\text { as Fo) }\end{array}$ & $\begin{array}{l}\text { Iron, } \\
\text { dle- } \\
\text { solved } \\
\left(\mu g /{ }^{2}\right. \\
\text { as Fo) }\end{array}$ & $\begin{array}{c}\text { Manga- } \\
\text { nese, } \\
\text { total } \\
\text { recov- } \\
\text { erable } \\
\text { ( } \mu \mathrm{g} / \mathrm{h} \\
\text { as } \mathrm{Mn} \text { ) }\end{array}$ & $\begin{array}{c}\text { Manga- } \\
\text { nese, } \\
\text { dls- } \\
\text { solved } \\
(\mu \mathrm{g} / \mathrm{L} \\
\text { as } \mathrm{Mn}) \\
\end{array}$ & $\begin{array}{l}8 \mathrm{D}, \\
\text { per } \\
\mathrm{mil}\end{array}$ & $\begin{array}{c}\delta^{18} \mathrm{O} \\
\text { per } \\
\text { mil }\end{array}$ & & \\
\hline P3 & $02-26-85$ & $\ldots$ & -. & -. & -- & -- & -54.0 & -8.40 & & \\
\hline P4 & $02-26-85$ & -- & -- & -- & -- & -. & -54.5 & -8.50 & & \\
\hline P6 & $02-26-85$ & -- & -- & -- & -- & -- & -55.0 & -8.50 & & \\
\hline $\mathrm{D} 2$ & $02-26-85$ & 20 & 8600 & 2500 & 200 & 100 & -54.0 & -8.35 & & \\
\hline S3 & $02-26-85$ & 10 & 350 & 30 & 1900 & 1900 & -- & -- & - & \\
\hline D4 & $02-25-85$ & 20 & 7700 & 990 & 180 & 66 & -54.0 & -8.30 & & \\
\hline S5 & $02-25-85$ & - & -. & - & -. & -- & -54.0 & -8.40 & & \\
\hline S8 & $02-26-85$ & -- & -- & - & -- & -- & -55.5 & -8.60 & & \\
\hline D9 & $02-26-85$ & -- & -. & -- & -- & -- & -54.5 & -8.50 & & \\
\hline 17 & $02-25-85$ & $<10$ & 3800 & 2300 & 100 & 94 & -54.5 & -8.25 & & \\
\hline KBC AT SR & $02-26-85$ & -- & - & -- & - & - & -71.0 & -10.70 & & \\
\hline
\end{tabular}


Table 19. Water-quality records for ground-water and surface-water samples, Killbuck Creek valley near Wooster, Ohio-Continued

Sample 6: March 19-21, 1985

\begin{tabular}{|c|c|c|c|c|c|c|c|c|c|c|c|}
\hline $\begin{array}{l}\text { Local } \\
\text { Identifier }\end{array}$ & \multicolumn{2}{|c|}{$\begin{array}{l}\text { Station } \\
\text { number }\end{array}$} & Date & $\begin{array}{l}\text { Type } \\
\text { of } \\
\text { site }\end{array}$ & Time & $\begin{array}{l}\text { Water } \\
\text { level } \\
\text { (feet) }\end{array}$ & \multicolumn{2}{|c|}{$\begin{array}{l}\text { Spe- } \\
\text { cific } \\
\text { con- } \\
\text { duct- } \\
\text { ance } \\
(\mu S / c m)\end{array}$} & $\begin{array}{l}\text { pH } \\
\text { (stand- } \\
\text { ard } \\
\text { units) }\end{array}$ & $\underset{\text { (mv) }}{\text { Eh }}$ & $\begin{array}{c}\text { Temper } \\
\text { ature, } \\
\text { air } \\
\text { (deg. C) }\end{array}$ \\
\hline P3 & \multicolumn{2}{|c|}{404802081583400} & $03-21-85$ & DGW & 0800 & 36.50 & $\ldots$ & 615 & 7.4 & 80 & 3.0 \\
\hline P5 & \multicolumn{2}{|c|}{404800081583100} & $03-21-85$ & DGW & 0830 & 35.80 & -. & 1070 & 7.1 & 200 & 3.0 \\
\hline P6 & \multicolumn{2}{|c|}{404759081583000} & $03-21-85$ & DGW & 0850 & 35.00 & -- & 940 & 7.0 & 180 & 0.0 \\
\hline P7 & 404758081 & 82900 & $03-21-85$ & DGW & 091 & 36. & 31 & 9 & 7.2 & 180 & 1.0 \\
\hline $\mathrm{D} 2$ & 404802081 & 83102 & $03-20-85$ & DGW & 104 & 28. & 1 & 6 & 7.4 & 150 & 10.0 \\
\hline S3 & 404802081 & 83103 & $03-20-85$ & DGW & 091 & 26. & 38 & 28 & 6.6 & 260 & 7.0 \\
\hline D4 & 404800081 & 84500 & $03-20-85$ & DGW & 135 & 18. & 76 & 8 & 7.6 & 120 & 14.0 \\
\hline S5 & 404800081 & 84501 & $03-20-85$ & DGW & 123 & 18. & 55 & 8 & 7.1 & 200 & 14.0 \\
\hline D6 & 404839081 & 90900 & $03-21-85$ & DGW & 141 & 4. & 97 & 4 & 7.8 & 90 & 9.0 \\
\hline S7 & 404807081 & 82000 & 03-20-85 & DGW & 164 & 18. & 59 & 9 & 7.3 & 410 & 5.0 \\
\hline S8 & 404805081 & 82600 & $03-19-85$ & DGW & 155 & 21. & 54 & 8 & 6.9 & 350 & 5.0 \\
\hline D9 & 404805081 & 82601 & $03-19-85$ & DGW & 165 & 25 . & 73 & 5 & 7.6 & 160 & 5.0 \\
\hline D10 & 404752081 & 83400 & $03-21-85$ & DGW & 102 & 25 . & 73 & 8 & 7.1 & 180 & 3.0 \\
\hline S11 & 404752081 & 83401 & $03-21-85$ & DGW & 112 & 24. & 16 & 8 & 6.8 & 190 & 5.0 \\
\hline D12 & 404744081 & 82100 & $03-21-85$ & DGW & 122 & 21. & 15 & 7 & 7.0 & 180 & 9.0 \\
\hline 14 & 404758081 & 85900 & $03-21-85$ & RGW & 155 & & -- & 12 & 7.7 & 130 & 12.0 \\
\hline 17 & 404759081 & 82100 & $03-21-85$ & DGW & 110 & & - & 14 & 6.6 & -- & 10.0 \\
\hline & 404854081 & 91200 & $03-20-85$ & DSP & 151 & & - & 4 & 6.9 & 390 & 15.0 \\
\hline CC AT USR & 404848081 & 80900 & $03-19-85$ & SW & 113 & & -- & 4 & 7.9 & -- & 4.5 \\
\hline KBC AT SR & 404838081 & 85200 & 03-19-85 & SW & 131 & & 61 & & 8.2 & -- & 10.0 \\
\hline KBC AT OMR & 03138800 & & $03-19-85$ & SW & 151 & & 76 & & 8.3 & -- & 11.0 \\
\hline $\begin{array}{l}\text { Local } \\
\text { Identifier }\end{array}$ & Date & $\begin{array}{c}\text { Temper- } \\
\text { ature, } \\
\text { water } \\
\text { (deg. C) }\end{array}$ & $\begin{array}{c}\text { Oxygen, } \\
\text { dls- } \\
\text { solved } \\
(\mathrm{mgh}) \\
\end{array}$ & $\begin{array}{r}\text { Oxy } \\
\text { dif } \\
\text { sol } \\
\text { (per } \\
\text { eat } \\
\text { atic }\end{array}$ & $\begin{array}{l}\text { gen, } \\
\text { sed } \\
\text { sent } \\
\text { ur- } \\
\text { n) }\end{array}$ & $\begin{array}{c}\text { Hard- } \\
\text { ness, } \\
\text { total } \\
\text { (mgl } \\
\text { as } \\
\mathrm{CaCO}_{3} \text { ) }\end{array}$ & $\begin{array}{c}\text { Calcium, } \\
\text { dis- } \\
\text { solved } \\
\text { (mgl } \\
\text { as Ca) }\end{array}$ & $\begin{array}{l}\text { Magne- } \\
\text { sium, } \\
\text { dis- } \\
\text { solved } \\
\text { (mgh } \\
\text { as Mg) }\end{array}$ & $\begin{array}{l}\text { Sodlum, } \\
\text { dls- } \\
\text { solved } \\
\text { (mgl } \\
\text { as Na) }\end{array}$ & $\begin{array}{l}\text { Sodilum, } \\
\text { percent }\end{array}$ & $\begin{array}{l}\text { Sodium } \\
\text { ad- } \\
\text { sorp- } \\
\text { tion } \\
\text { ratio } \\
\end{array}$ \\
\hline P3 & $03-21-85$ & 10.5 & 0.3 & 3 & 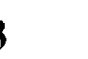 & - & - & - & -- & -- & -- \\
\hline P5 & $03-21-85$ & 10.0 & 0.4 & 2 & 4 & 430 & 130 & 25 & 63 & 24 & 1 \\
\hline P6 & $03-21-85$ & 10.5 & 0.2 & 2 & 2 & -. & -- & -- & -- & -- & -- \\
\hline $\mathrm{P} 7$ & $03-21-85$ & 10.5 & 0.2 & 2 & 2 & -- & -- & -- & -- & - & -- \\
\hline $\mathrm{D} 2$ & $03-20-85$ & 11.0 & 0.2 & 2 & 2 & -- & -- & -- & -- & -- & - \\
\hline S3 & $03-20-85$ & 11.5 & 0.2 & 2 & 2 & -. & -- & -. & -- & - & -- \\
\hline D4 & $03-20-85$ & 12.0 & 0.3 & 3 & 3 & 370 & 98 & 30 & 48 & 22 & 1 \\
\hline S5 & $03-20-85$ & 12.0 & 0.1 & 1 & 1 & 400 & 120 & 24 & 29 & 14 & 0.6 \\
\hline D6 & $03-21-85$ & 11.0 & $<0.1$ & - & & 240 & 65 & 18 & 11 & 9 & 0.3 \\
\hline S7 & $03-20-85$ & 10.0 & -- & . & & .. & -- & -- & - & - & -- \\
\hline
\end{tabular}


Table 19. Water-quality records for ground-water and surface-water samples, Killbuck Creek valley near Wooster, Ohio-Continued

Sample 6: March 19-21, 1985-Continued

\begin{tabular}{|c|c|c|c|c|c|c|c|c|c|c|}
\hline $\begin{array}{l}\text { Local } \\
\text { Identlifer }\end{array}$ & Date & $\begin{array}{l}\text { Temper- } \\
\text { ature, } \\
\text { water } \\
\text { (deg. C) }\end{array}$ & $\begin{array}{l}\text { Oxygen, } \\
\text { dls- } \\
\text { solved } \\
\text { (mg/L) }\end{array}$ & $\begin{array}{l}\text { Oxygen, } \\
\text { dls- } \\
\text { solved } \\
\text { (percent } \\
\text { estur- } \\
\text { ation) }\end{array}$ & $\begin{array}{c}\text { Herd- } \\
\text { neas, } \\
\text { total } \\
\text { (mg/h } \\
\text { as } \\
\left.\mathrm{CaCO}_{3}\right)\end{array}$ & $\begin{array}{l}\text { Caiclum, } \\
\text { dls- } \\
\text { solved } \\
\text { (mgll } \\
\text { as Ca) }\end{array}$ & $\begin{array}{l}\text { Magno- } \\
\text { slum, } \\
\text { dls- } \\
\text { solved } \\
\text { (mg/L } \\
\text { as Mg) }\end{array}$ & $\begin{array}{l}\text { Sodlum, } \\
\text { dls- } \\
\text { solved } \\
\text { (mgh } \\
\text { as Na) }\end{array}$ & $\begin{array}{l}\text { Sodlum, } \\
\text { percent }\end{array}$ & $\begin{array}{r}\text { Sodlu } \\
\text { ad- } \\
\text { sorp } \\
\text { tlon } \\
\text { ratio }\end{array}$ \\
\hline S8 & $03-19-85$ & 11.0 & 0.3 & 3 & -- & -- & -- & -- & -- & -- \\
\hline D9 & $03-19-85$ & 11.0 & 0.1 & 1 & -- & -- & - & -- & -- & -- \\
\hline D10 & $03-21-85$ & 10.0 & $<0.1$ & -- & -- & - & - & -- & -- & -- \\
\hline $\mathbf{S 1 1}$ & $03-21-85$ & 10.5 & $<0.1$ & -- & -- & -- & -- & -- & -- & -- \\
\hline D12 & $03-21-85$ & 10.5 & $<0.1$ & -- & - & -- & - & -- & -- & -- \\
\hline 14 & $03-21-85$ & 11.0 & $<0.1$ & $\ldots$ & 260 & 68 & 22 & 150 & 55 & 4 \\
\hline 17 & $03-21-85$ & 11.5 & 2.3 & 22 & - & -- & -- & -- & -- & -. \\
\hline 32 & $03-20-85$ & 7.5 & 7.2 & 62 & 200 & 54 & 16 & 14 & 13 & 0. \\
\hline CC AT USR & $03-19-85$ & 2.5 & 12.0 & -- & -- & -- & -. & -- & -- & -- \\
\hline KBC AT SR & $03-19-85$ & 5.0 & 11.4 & 93 & 210 & 58 & 17 & 20 & 17 & 0. \\
\hline KBC AT OMR & $03-19-85$ & 6.0 & 12.8 & 107 & - & - & -- & -- & -- & - \\
\hline
\end{tabular}

\begin{tabular}{|c|c|c|c|c|c|c|c|c|c|c|}
\hline $\begin{array}{l}\text { Local } \\
\text { Identifler }\end{array}$ & Date & $\begin{array}{l}\text { Polas- } \\
\text { sium, } \\
\text { dis- } \\
\text { solved } \\
\text { (mg/L } \\
\text { se K) } \\
\end{array}$ & $\begin{array}{c}\text { Bicar- } \\
\text { bonate, } \\
\text { WH FET, } \\
\text { fleld } \\
\text { (mgl as as } \\
\mathrm{HCO}_{3} \text { ) } \\
\end{array}$ & $\begin{array}{c}\text { Alka- } \\
\text { llinlty, } \\
\text { WH FET, } \\
\text { fieid } \\
\left(\mathrm{mgh}^{2} \text { as }\right. \\
\left.\mathrm{CaCO}_{3}\right) \\
\end{array}$ & $\begin{array}{c}\text { Sulfate, } \\
\text { dls- } \\
\text { solved } \\
\text { (mg/ } \\
\text { as } \mathrm{SO}_{4} \text { ) }\end{array}$ & $\begin{array}{l}\text { Chio- } \\
\text { ride, } \\
\text { dis- } \\
\text { oolved } \\
\text { (mg/ } \\
\text { as Cl) } \\
\end{array}$ & $\begin{array}{l}\text { Fiuo- } \\
\text { ride, } \\
\text { dls- } \\
\text { solved } \\
\text { (mgh } \\
\text { as F) } \\
\end{array}$ & $\begin{array}{c}\text { Slllea, } \\
\text { dle- } \\
\text { solved } \\
\text { (mgh } \\
\mathrm{as} \\
\mathrm{SIO}_{2} \text { ) } \\
\end{array}$ & $\begin{array}{l}\text { Sollds, } \\
\text { residue, } \\
\text { at } 180 \\
\text { deg. C, } \\
\text { dls- } \\
\text { solved } \\
\text { (mg/L) } \\
\end{array}$ & $\begin{array}{l}\text { Sollds, } \\
\text { sum of } \\
\text { consti- } \\
\text { tuenta, } \\
\text { dis- } \\
\text { solved } \\
\text { (mg/L) } \\
\end{array}$ \\
\hline P3 & $03.21-85$ & -- & -- & -. & .- & -- & -- & -. & -- & - \\
\hline P5 & $03-21-85$ & 1.7 & 380 & 315 & 82 & 130 & 0.2 & 13 & 700 & 637 \\
\hline P6 & $03-21-85$ & -- & -- & -- & -- & -- & -- & -- & -. & -- \\
\hline P7 & $03-21-85$ & -. & -- & -. & -- & -- & -- & -- & -- & -. \\
\hline D2 & $03-20-85$ & - & -- & - & -- & -- & -- & -- & -- & $-\cdot$ \\
\hline S3 & $03-20-85$ & -. & 500 & 409 & - & -- & -- & -- & -- & -- \\
\hline D4 & $03-20-85$ & 2.0 & 340 & 279 & 88 & 38 & 0.2 & 13 & 473 & 487 \\
\hline S5 & $03-20-85$ & 1.3 & 360 & 293 & 83 & 62 & 0.1 & 20 & 497 & 518 \\
\hline D6 & $03-21-85$ & 1.2 & 220 & 183 & 39 & 37 & 0.2 & 9.8 & 292 & 302 \\
\hline S7 & 03-20-85 & -. & -- & -- & -- & -- & -- & -- & -- & -- \\
\hline S8 & $03-19-85$ & -. & -. & -. & -- & -- & -- & -- & -- & -- \\
\hline D9 & $03-19-85$ & -- & -. & - & -. & -- & -- & -- & -- & -- \\
\hline D10 & $03-21-8.5$ & .. & -- & - & .. & -- & -. & -- & -- & -- \\
\hline S11 & $0.3-21-85$ & -- & -- & -- & -- & -- & -- & -. & -- & -- \\
\hline D12 & $03-21-85$ & -- & -- & -- & -- & -- & -- & -- & -- & - \\
\hline 14 & $03-21-85$ & 2.5 & -. & -. & 6.8 & 280 & $<0.1$ & 12 & 671 & 667 \\
\hline 17 & (13-21-85 & -- & -- & -- & -- & -- & -- & -- & -- & -- \\
\hline 32 & $03-20-85$ & 2.5 & 160 & 128 & 43 & 36 & 0.1 & 5.3 & 276 & 265 \\
\hline CC AT USR & $03-19-85$ & -. & .- & .. & -. & -- & -. & -- & -. & -- \\
\hline KBC AT SR & $03-19-85$ & 3.0 & 160 & 128 & 63 & 40 & 0.1 & 4.1 & 300 & 297 \\
\hline
\end{tabular}

KBC AT OMR $\quad 03-19-85$ 
Table 19. Water-quality records for ground-water and surface-water samples, Killbuck Creek valley near Wooster, Ohio-Continued

Sample 6: March 19-21, 1985-Continued

\begin{tabular}{|c|c|c|c|c|c|c|c|c|c|c|}
\hline \multirow[b]{2}{*}{$\begin{array}{l}\text { Locei } \\
\text { Identifier }\end{array}$} & \multirow[b]{2}{*}{ Dats } & \multirow[b]{2}{*}{$\begin{array}{c}\text { Solids, } \\
\text { dls- } \\
\text { solved } \\
\text { (tons } \\
\text { per } \\
\text { day) }\end{array}$} & \multicolumn{6}{|c|}{ Forms of nitrogen } & \multirow[b]{2}{*}{$\begin{array}{l}\text { Phos- } \\
\text { phorus, } \\
\text { crtho, } \\
\text { dis- } \\
\text { soived } \\
\text { (mg/L } \\
\text { as P) }\end{array}$} & \multirow[b]{2}{*}{$\begin{array}{c}\text { Phos- } \\
\text { phate, } \\
\text { ortho, } \\
\text { dls- } \\
\text { solved } \\
\left(\mathrm{mg}^{\prime} / \mathrm{L}\right. \\
\left.\text { as } \mathrm{PO}_{4}\right)\end{array}$} \\
\hline & & & $\begin{array}{l}\text { Nitrate, } \\
\text { dis- } \\
\text { solved } \\
\text { (mg/L } \\
\text { as N) }\end{array}$ & $\begin{array}{l}\text { Nitilte, } \\
\text { dis- } \\
\text { solved } \\
\text { (mg/L } \\
\text { as N) }\end{array}$ & $\begin{array}{l}\mathrm{NO}_{2}+ \\
\mathrm{NO}_{3}, \\
\text { dis- } \\
\text { solved } \\
(\mathrm{mg} / \\
\mathrm{as} \mathrm{N}) \\
\end{array}$ & $\begin{array}{c}\text { Ammonia, } \\
\text { dls- } \\
\text { solved } \\
\text { (mg/l } \\
\text { as N) }\end{array}$ & $\begin{array}{l}\text { Organic, } \\
\text { dle- } \\
\text { solved } \\
\text { (mg/l } \\
\text { as N) }\end{array}$ & $\begin{array}{c}\text { Ammonla } \\
\text { + organlc, } \\
\text { dis- } \\
\text { solved } \\
\text { (mg/l } \\
\text { as N) }\end{array}$ & & \\
\hline P3 & $03-21-85$ & $\cdots$ & -- & -- & -. & .. & -- &.- & -- & -- \\
\hline P5 & $03-21-85$ & - & -- & $<0.010$ & $<0.100$ & 0.230 & 0.07 & 0.30 & 0.010 & 0.03 \\
\hline P6 & $03-21-85$ & -- & -- & -- & -- & -- & -- & -- & -- & -- \\
\hline P7 & $03-21-85$ & -. & -- & -- & -- & -- & -- & $\cdots$ & -- & -- \\
\hline $\mathrm{D} 2$ & $03-20-85$ & -- & -- & -. & -- & -- & -- & -- & -- & -- \\
\hline S3 & $03-20-85$ & -- & -- & -- & -- & $\ldots$ & -- & -- & -- & -- \\
\hline D4 & $03-20-85$ & -- & -- & $<0.010$ & 0.200 & 0.120 & 0.48 & 0.60 & $<0.010$ & -- \\
\hline S5 & $03-20-85$ & -- & -- & $<0.010$ & $<0.100$ & 0.710 & 0.0 & 0.70 & $<0.010$ & -- \\
\hline D6 & $03-21-85$ & -- & -- & $<0.010$ & 2.40 & 0.020 & 0.28 & 0.30 & $<0.010$ & - \\
\hline$\$ 7$ & $03-20-85$ & $\cdots$ & -- & - & -- & -- & - & -- & - & -. \\
\hline S8 & $03-19-85$ & -- & -- & - & - & - & -. & -- & - & -- \\
\hline D9 & $03-19-85$ & -- & -- & -- & $\cdots$ & -- & - & -- & -- & -- \\
\hline D10 & $03-21-85$ & -- & -- & -- & -- & $\ldots$ & -- & -- & -- & -- \\
\hline$\$ 11$ & $03-21-85$ & -- & -- & -- & -. & -- & -- & -- &.- & -- \\
\hline D12 & $03-21-85$ & -- & $\cdots$ & - & - & -- & -- & -- & -- & -- \\
\hline 14 & $03-21-85$ & -- & -- & $<0.010$ & $<0.100$ & 0.430 & 0.07 & 0.50 & $<0.010$ & -- \\
\hline 17 & $03-21-85$ & -- & -- & -- & -- & -- & -- & -. & -- & -- \\
\hline 32 & $03-20-85$ & -- & -- & $<0.010$ & 3.90 & $<0.010$ & -- & 0.10 & $<0.010$ & -- \\
\hline CC AT USR & $(13-19-85$ & -- & -- & -- & -- & -- & -- & $\sim$ & -- & -- \\
\hline KBC AT SR & $03-19-85$ & 49.4 & 3.39 & 0.010 & 3.40 & 0.060 & 0.34 & 0.40 & 0.020 & 0.06 \\
\hline KBC AT OMR & $03-19-85$ & -- & -- & -- & -- & -- & - & -- & -- & -- \\
\hline $\begin{array}{l}\text { Local } \\
\text { Identifier }\end{array}$ & Date & $\begin{array}{l}\text { Alum- } \\
\text { inum, } \\
\text { total } \\
\text { recov- } \\
\text { erabls } \\
\text { (11g/L } \\
\text { as AI) } \\
\end{array}$ & $\begin{array}{l}\text { Alum- } \\
\text { Inum, } \\
\text { dis- } \\
\text { solved } \\
\text { (k1g/L } \\
\text { as Al) }\end{array}$ & $\begin{array}{c}\text { iron, } \\
\text { total } \\
\text { recov- } \\
\text { erable } \\
(\mu g / \mathrm{L} \\
\text { as } \mathrm{Fe})\end{array}$ & $\begin{array}{l}\text { Iron, } \\
\text { dis- } \\
\text { soived } \\
(\mu g / L \\
\text { as Fe) } \\
\end{array}$ & $\begin{array}{l}\text { Manga- } \\
\text { nese, } \\
\text { tolal } \\
\text { recov- } \\
\text { erable } \\
\text { ( } \mu \mathrm{g} / \mathrm{L} \\
\text { as } \mathrm{Mn}) \\
\end{array}$ & $\begin{array}{l}\text { Manga- } \\
\text { nese, } \\
\text { dis- } \\
\text { solved } \\
(\mu \mathrm{g} / \\
\text { as Mn) }\end{array}$ & $\begin{array}{l}80, \\
\text { per } \\
\text { mil }\end{array}$ & $\begin{array}{c}\delta^{18} \mathrm{O} \\
\text { per } \\
\mathrm{mil}\end{array}$ & \\
\hline P3 & $03-21-85$ & -- & -- & -- & - & -- & -- & -54.5 & -8.40 & \\
\hline P5 & $03-21-85$ & 10 & $<10$ & 3000 & 2900 & 230 & 230 & -54.0 & -8.50 & \\
\hline P6 & $03-21-85$ & -- & - & -- & -- & $-\cdots$ & -- & -56.0 & -8.50 & \\
\hline P7 & $03-21-85$ & $\cdots$ & -- & -- & -- & -- & -. & -- & -- & \\
\hline D2 & $03-20-85$ & -- & -- & -- & -- & -- & -- & -54.0 & -8.30 & \\
\hline \$3 & $03-20-85$ & -- & -. & -. & -- & -. & -- & -53.5 & -8.10 & \\
\hline D4 & $03-20-85$ & 360 & 20 & 4900 & 1100 & 170 & 66 & -53.0 & -8.50 & \\
\hline S5 & $03-20-85$ & 190 & 20 & 2200 & 1100 & 950 & 860 & -54.0 & -8.25 & \\
\hline D6 & $03-21-85$ & 80 & 10 & 1100 & 730 & 20 & 33 & -52.5 & -8.40 & \\
\hline S7 & $03-20-85$ & -- & - & -- & -- & -- & -- & -- & -- & \\
\hline
\end{tabular}


Table 19. Water-quality records for ground-water and surface-water samples, Killbuck Creek valley near Wooster, Ohio-Continued

Sample 6: March 19-21, 1985-Continued

\begin{tabular}{|c|c|c|c|c|c|c|c|c|c|}
\hline $\begin{array}{l}\text { Local } \\
\text { identifler }\end{array}$ & Date & $\begin{array}{l}\text { Alum- } \\
\text { inum, } \\
\text { total } \\
\text { recov- } \\
\text { erable } \\
\text { ( } 1 \mathrm{~g} / \mathrm{h} \\
\text { as Al) }\end{array}$ & $\begin{array}{l}\text { Alum- } \\
\text { inum, } \\
\text { dis- } \\
\text { solved } \\
(\mu \mathrm{g} / \mathrm{L} \\
\text { as Al) }\end{array}$ & $\begin{array}{l}\text { Iron, } \\
\text { total } \\
\text { recov- } \\
\text { erable } \\
(\mu g / L \\
\text { as } \mathrm{Fe})\end{array}$ & $\begin{array}{l}\text { Iron, } \\
\text { dis- } \\
\text { solved } \\
\text { ( } \mu g / \mathrm{L} \\
\text { as Fe) }\end{array}$ & $\begin{array}{c}\text { Manga- } \\
\text { nese, } \\
\text { total } \\
\text { recov- } \\
\text { erable } \\
\text { ( } \mu \mathrm{g} / \mathrm{L} \\
\text { as } \mathrm{Mn} \text { ) }\end{array}$ & $\begin{array}{l}\text { Mange- } \\
\text { nese, } \\
\text { dls- } \\
\text { solved } \\
(\mu g / L \\
\text { as Mn) }\end{array}$ & $\begin{array}{l}\delta D, \\
\text { per } \\
\text { mil }\end{array}$ & $\begin{array}{c}\delta^{18} 0 \\
\text { per } \\
\text { mil }\end{array}$ \\
\hline S8 & $03-19-85$ & -- & -- & -. & - & -- & - & -51.5 & -8.30 \\
\hline D9 & $03-19-85$ & -- & -- & -- & -- & -- & -- & -54.0 & .8 .30 \\
\hline D10 & $03-21-85$ & -- & -- & -- & -- & -- & -- & -53.0 & -7.95 \\
\hline $\mathbf{S 1 1}$ & $03-21-85$ & -- & -- & - & -- & - & -- & - & -- \\
\hline D12 & $03-21-85$ & -- & - & $\therefore$ & -- & -- & -- & -53.5 & -8.05 \\
\hline 14 & $03-21-85$ & 40 & $<10$ & 680 & 550 & 100 & 100 & -55.0 & -8.60 \\
\hline 17 & $03-21-85$ & -- & -- & - & -- & -- & -- & -51.0 & -6.95 \\
\hline 32 & $03-20-85$ & 30 & 10 & 210 & 7 & $<10$ & 1 & -52.0 & -7.65 \\
\hline CC AT USR & $03-19-85$ & -- & -- & -- & -- & -- & -- & -55.0 & -8.55 \\
\hline KBC AT SR & $03-19-85$ & 70 & 10 & 390 & 12 & 40 & 47 & -53.5 & -8.30 \\
\hline KBC AT OMR & $03-19-85$ & -- & -- & -- & -- & -- & -- & -53.5 & -8.20 \\
\hline
\end{tabular}

Sample 7: April 30 - May 3, 1985

\begin{tabular}{|c|c|c|c|c|c|c|c|c|c|c|}
\hline $\begin{array}{l}\text { Local } \\
\text { Identifier }\end{array}$ & $\begin{array}{l}\text { Station } \\
\text { number }\end{array}$ & Date & $\begin{array}{l}\text { Type } \\
\text { of } \\
\text { slte }\end{array}$ & Time & $\begin{array}{l}\text { Water } \\
\text { level } \\
\text { (feot) }\end{array}$ & 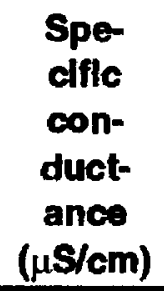 & $\begin{array}{l}\text { pH } \\
\text { (atand- } \\
\text { ard } \\
\text { unlta) }\end{array}$ & $\begin{array}{c}\text { Eh } \\
\text { (mv) }\end{array}$ & $\begin{array}{c}\text { Temper- } \\
\text { ature, } \\
\text { air } \\
\text { (deg. C) }\end{array}$ & $\begin{array}{l}\text { Temper- } \\
\text { ature, } \\
\text { water } \\
\text { (deg. C) }\end{array}$ \\
\hline P3 & 404802081583400 & $05-03-85$ & DGW & 0840 & -- & 835 & 7.3 & 110 & 10.0 & 10.5 \\
\hline P4 & 104801081583300 & $05-03-85$ & DGW & 0810 & $\ldots$ & 810 & 7.0 & 170 & 10.0 & 11.0 \\
\hline P6 & 404759081583000 & $05-03-85$ & DGW & 0930 & -- & 965 & 6.9 & 180 & 12.0 & 10.5 \\
\hline P7 & 404758081582900 & $05-03-85$ & DGW & 0910 & $\cdots$ & 990 & 7.0 & 170 & 12.0 & 10.5 \\
\hline $\mathrm{D} 2$ & 404802081583102 & $04-30-85$ & DGW & 1200 & 28.34 & 560 & 7.4 & 110 & 20.0 & 11.5 \\
\hline S3 & 404802081.583103 & $04-30-85$ & DGW & 1020 & 28.05 & 2480 & 6.4 & 310 & 13.0 & 11.0 \\
\hline D4 & 404800081584500 & $04-29-85$ & DGW & 1610 & 18.88 & 775 & 7.5 & 130 & 20.0 & 12.5 \\
\hline S5 & 404800081584501 & $04-29-85$ & DGW & 1425 & 18.55 & 810 & 7.0 & 180 & 20.0 & 12.0 \\
\hline D6 & 404839081590900 & $05-01-85$ & DGW & 1140 & 4.23 & 490 & 7.7 & 80 & 18.0 & 11.0 \\
\hline S7 & 404807081582000 & $05-01-85$ & DGW & 0830 & 16.95 & 780 & 6.5 & 390 & 12.0 & 10.5 \\
\hline S8 & 404805081582600 & $04-30-85$ & DGW & 1600 & 20.81 & 755 & 6.9 & 280 & 26.0 & 12.0 \\
\hline D9 & 404805081582601 & $04-30-85$ & DGW & 1500 & 25.90 & 570 & 7.6 & 100 & 20.0 & 11.5 \\
\hline D10 & 404752081583400 & $05-02-85$ & DGW & 1000 & 26.23 & 790 & 7.0 & 170 & 12.0 & 10.5 \\
\hline S11 & 404752081583401 & $05-02-85$ & DGW & 1100 & 24.55 & 855 & 6.8 & 170 & 12.0 & 10.0 \\
\hline D12 & 404744081582100 & $05-02-85$ & DGW & 1250 & 22.41 & 825 & 6.9 & 180 & 12.0 & 10.5 \\
\hline
\end{tabular}


Table 19. Water-quality records for ground-water and surface-water samples, Killbuck Creek valley near Wooster, Ohio-Continued

Sample 7: April 30 - May 3, 1985-Continued

\begin{tabular}{|c|c|c|c|c|c|c|c|c|c|c|}
\hline $\begin{array}{l}\text { Local } \\
\text { Identifier }\end{array}$ & $\begin{array}{l}\text { Station } \\
\text { number }\end{array}$ & Date & $\begin{array}{c}\text { Typo } \\
\text { of } \\
\text { eite }\end{array}$ & Tlme & $\begin{array}{l}\text { Water } \\
\text { lovel } \\
\text { (foet) }\end{array}$ & $\begin{array}{l}\text { Spe- } \\
\text { ciflc } \\
\text { con- } \\
\text { duct- } \\
\text { ance } \\
(\mu S / c m)\end{array}$ & $\begin{array}{c}\text { pH } \\
\text { (stand- } \\
\text { ard } \\
\text { units) }\end{array}$ & $\begin{array}{c}\text { Eh } \\
(m v)\end{array}$ & $\begin{array}{c}\text { Temper- } \\
\text { ature, } \\
\text { air } \\
\text { (deg. C) }\end{array}$ & $\begin{array}{l}\text { Temper- } \\
\text { ature, } \\
\text { water } \\
\text { (deg. C) }\end{array}$ \\
\hline 14 & 404758081585900 & $05-03-85$ & RGW & 1050 & -- & 1220 & 7.5 & 120 & 18.0 & 11.5 \\
\hline 17 & 404759081582100 & $05-02-85$ & DGW & 1520 & -- & 1480 & 7.2 & 150 & 16.0 & 11.5 \\
\hline 20 & 404802081594100 & $05-03-85$ & RGW & 1140 & 27.39 & 464 & 7.2 & 250 & -- & 12.5 \\
\hline 32 & 404854081591200 & $05-01-85$ & DSP & 1530 & -- & 470 & 7.4 & 350 & 18.0 & 9.5 \\
\hline CC AT USR & 404848081580900 & $05-(01-85$ & SW & 1330 & -- & 402 & 9.0 & 270 & 20.0 & 15.0 \\
\hline KBC AT SR & 4048.38081585200 & $05-01-85$ & SW & 1250 & -- & 535 & 8.0 & 300 & 18.0 & 15.0 \\
\hline KBC AT OMR & $031388(0)$ & $05-01-85$ & SW & 0850 & - & 540 & 8.0 & 360 & 13.0 & 15.0 \\
\hline
\end{tabular}

\begin{tabular}{|c|c|c|c|c|c|c|c|c|c|}
\hline $\begin{array}{l}\text { Local } \\
\text { Identifier }\end{array}$ & Date & $\begin{array}{l}\text { Oxygen, } \\
\text { dls- } \\
\text { solved } \\
\text { (mg/L) }\end{array}$ & $\begin{array}{c}\text { Oxygen, } \\
\text { dle- } \\
\text { solved } \\
\text { (percent } \\
\text { satur- } \\
\text { ation) }\end{array}$ & $\begin{array}{c}\text { Hard- } \\
\text { nese, } \\
\text { tolal } \\
\text { (mg/l } \\
\text { as } \\
\mathrm{CaCO}_{3} \text { ) }\end{array}$ & $\begin{array}{l}\text { Calclum, } \\
\text { dis- } \\
\text { solved } \\
\text { (mg/L } \\
\text { as Ca) }\end{array}$ & $\begin{array}{l}\text { Magne- } \\
\text { slum, } \\
\text { dle- } \\
\text { solved } \\
\text { (mg/L } \\
\text { as Mg) }\end{array}$ & $\begin{array}{l}\text { Sodlum, } \\
\text { dle- } \\
\text { solved } \\
\text { (mgh } \\
\text { as } \mathrm{Na} \text { ) }\end{array}$ & $\begin{array}{l}\text { Sodlum, } \\
\text { percent }\end{array}$ & $\begin{array}{c}\text { Sodlum } \\
\text { ad- } \\
\text { sorp- } \\
\text { tlon } \\
\text { ratlo }\end{array}$ \\
\hline P3 & (55-03-85 & $<0.1$ & -- & -- & -- & -. & -- & -- & - \\
\hline P4 & $05-03-85$ & $<0.1$ & -- & -- & -- & -- & -- & -. & -- \\
\hline P6 & $05-03-85$ & $<0.1$ &.- & .. & -- & -- & -- & -- & -- \\
\hline $\mathrm{P} 7$ & $05-03.85$ & $<0.1$ & -. & -- & -- & -- & -- & -- & - \\
\hline $\mathrm{D} 2$ & $04-30-85$ & $<0.1$ & -- & -- & - & -- & -- & -- & - \\
\hline S3 & $04-30-85$ & $<0.1$ & - & -. & - & -- & 17 & -- & -- \\
\hline D4 & 04-29-85 & 0.1 & 1 & -. & $\cdots$ & -- & -. & -- & - \\
\hline S5 & $04-29-85$ & 0.1 & 1 & -- & -- & -- & $\ldots$ & -. & -- \\
\hline D6 & $05-01-85$ & $<0.1$ & -- & -. & -- & -- & -- & -- & -- \\
\hline S7 & $05-01-85$ & 1.5 & 14 & -- & -- & -- & -- & -- & -- \\
\hline S8 & $04-30-85$ & $<0.1$ & -. & 370 & 110 & 23 & 15 & 8 & 0.3 \\
\hline D9 & 04-30-85 & $<0.1$ &.- & -. & -- & -- & -- & -- & -- \\
\hline D10 & $05-02-85$ & $<0.1$ & -- & -- & -- & -- & -- & -- & -- \\
\hline S11 & $05-02-85$ & $<0.1$ & -- & -- & -- & -- & -- & -- & - \\
\hline D12 & $05-02-85$ & $<0.1$ & $\cdots$ & - & -- & - & -- & - & -- \\
\hline 14 & $05-03-85$ & $<0.1$ & -- & $\cdots$ & -- & -- & -- & -- & - \\
\hline 17 & $05-02-85$ & $<0.1$ & - & - & -- & -- & -- & -- & - \\
\hline 20 & $05-03-85$ & 0.6 & 6 & -- & -- & -- & - & -- & -- \\
\hline 32 & $05-01-85$ & 5.8 & -- & -- & -- & -- & -- & -- & -- \\
\hline CC AT USR & $05-01-85$ & 12.2 & 126 & -- & $\cdots$ & - & -- & -- & -- \\
\hline KBC AT SR & $05-01-85$ & 8.8 & 91 & -- & -- & -- & -- & -- & -- \\
\hline KBC AT OMR & $05-01-85$ & 8.8 & 91 & -- & -- & -- & -- & -- & -- \\
\hline
\end{tabular}


Table 19. Water-quality records for ground-water and surface-water samples, Killbuck Creek valley near Wooster, Ohio-Continued

Sample 7: April 30 - May 3, 1985-Continued

\begin{tabular}{|c|c|c|c|c|c|c|c|c|c|}
\hline $\begin{array}{l}\text { Local } \\
\text { Identifier }\end{array}$ & Date & $\begin{array}{l}\text { Potas- } \\
\text { slum, } \\
\text { dis- } \\
\text { solved } \\
\text { (mg/L } \\
\text { as K) } \\
\end{array}$ & $\begin{array}{c}\text { Bloar- } \\
\text { bonate, } \\
\text { WH FET, } \\
\text { fleid } \\
\left(\mathrm{mg}^{2} \text { as }\right. \\
\left.\mathrm{HCO}_{3}\right)\end{array}$ & $\begin{array}{c}\text { Alka- } \\
\text { Inity, } \\
\text { WH FET, } \\
\text { field } \\
\text { (mg/l as } \\
\left.\mathrm{CaCO}_{3}\right)\end{array}$ & $\begin{array}{l}\text { Suifate, } \\
\text { dls- } \\
\text { solved } \\
\text { (mgh } \\
\text { as } \mathrm{SO}_{4} \text { ) }\end{array}$ & $\begin{array}{l}\text { Chlo- } \\
\text { ride, } \\
\text { dls- } \\
\text { solved } \\
\text { (mg/L } \\
\text { es Cl) } \\
\end{array}$ & $\begin{array}{l}\text { Fiuo- } \\
\text { ride, } \\
\text { dis- } \\
\text { solved } \\
\text { (mg/L } \\
\text { as F) }\end{array}$ & $\begin{array}{l}\text { Sllica, } \\
\text { dis- } \\
\text { solved } \\
\text { (mg/l } \\
\text { as } \\
\mathrm{SiO}_{2} \text { ) }\end{array}$ & $\begin{array}{c}\text { Sollds, } \\
\text { residue } \\
\text { at } 180 \\
\text { deg. C, } \\
\text { dis- } \\
\text { solved } \\
\text { (mg/L) } \\
\end{array}$ \\
\hline P3 & $05-03-85$ & -. & 250 & 208 & - & -- & -- & -- & -- \\
\hline P4 & $05-03-85$ & -- & -- & -- & - & -- & -- & -- & - \\
\hline P6 & $05-03-85$ & -- & 400 & 331 & -- & -- & -- & -- & -- \\
\hline P7 & $05-03-85$ & -. & 350 & 290 & -- & -- & -- & -- & -- \\
\hline D2 & $04-30-85$ & -- & 220 & 181 & -- & -- & -- & -- & -- \\
\hline S3 & $04-30-85$ & 7.6 & 630 & 519 & 1100 & 44 & $<0.1$ & 1.9 & 1980 \\
\hline D4 & $04-29-85$ & -- & 340 & 276 & - & -- & - & -. & -- \\
\hline S5 & $04-29-85$ & -- & 360 & 294 & - & -- & -- & -- & -- \\
\hline D6 & $05-01-85$ & -- & 220 & 181 & -- & -- & -- & -- & -- \\
\hline S7 & $05-01-85$ & -- & 220 & 184 & -- & -- & -- & -- & -- \\
\hline S8 & $04-30-85$ & 2.8 & 350 & 283 & 55 & 47 & $<0.1$ & 11 & 431 \\
\hline D9 & $04-30-85$ & $\because$ & 200 & 167 & -- & -- & -- & -- & -- \\
\hline D10 & $05-02-85$ & $\cdots$ & 400 & 324 & -- & -- & -- & -- & -- \\
\hline$S 11$ & $05-02-85$ & - & 450 & 372 & -- & -- & -- & -- & -- \\
\hline D12 & $05-02-85$ & -- & 410 & 338 & -- & - & -- & -- & -- \\
\hline 14 & $05-03-85$ & -- & 250 & 205 & -- & - & $-\infty$ & -- & -- \\
\hline 17 & $05-02-85$ & -- & 360 & 294 & - & - & -- & $\cdots$ & -- \\
\hline 20 & $05-03-85$ & -- & -- & $\cdots$ & -- & -. & -- & $-\cdot$ & -- \\
\hline 32 & $05-01-85$ & -- & 150 & 126 & -- & $\cdots$ & -- & -- & -- \\
\hline CC AT USR & $05-01-85$ & -- & 140 & 113 & -- & -- & - & -- & -- \\
\hline KBC AT SR & $05-01-85$ & -- & 230 & 192 & -- & -- & -- & -- & - \\
\hline KBC AT OMR & $05-01-85$ & -- & 170 & 137 & -- & -- & $\cdots$ & - & -- \\
\hline
\end{tabular}

\begin{tabular}{|c|c|c|c|c|c|c|c|c|c|}
\hline \multirow[b]{2}{*}{$\begin{array}{l}\text { Local } \\
\text { Identifier }\end{array}$} & \multirow[b]{2}{*}{ Date } & \multirow[b]{2}{*}{$\begin{array}{l}\text { Sollds, } \\
\text { sum of } \\
\text { const- } \\
\text { tuents, } \\
\text { dis- } \\
\text { solved } \\
\text { (mgll) }\end{array}$} & \multicolumn{6}{|c|}{ Forms of nltrogen } & \multirow[b]{2}{*}{$\begin{array}{l}\text { Phos- } \\
\text { phorus, } \\
\text { ortho, } \\
\text { dis-- } \\
\text { soived } \\
\text { (mg/h } \\
\text { as P) }\end{array}$} \\
\hline & & & $\begin{array}{l}\text { Nitrate, } \\
\text { dls- } \\
\text { solved } \\
\text { (mg/l } \\
\text { as N) }\end{array}$ & $\begin{array}{l}\text { Nitrite, } \\
\text { dls- } \\
\text { solved } \\
\text { (mg/l } \\
\text { as N) }\end{array}$ & $\begin{array}{c}\mathrm{NO}_{2}+ \\
\mathrm{NO}_{3} \text {, } \\
\text { dis- } \\
\text { solved } \\
(\mathrm{mg} / \mathrm{L} \\
\mathrm{as} \mathrm{N})\end{array}$ & $\begin{array}{c}\text { Ammonla, } \\
\text { dls- } \\
\text { solved } \\
\text { (mg/L } \\
\text { as N) }\end{array}$ & $\begin{array}{c}\text { Organlc, } \\
\text { dls-- } \\
\text { solved } \\
\text { (mg/L } \\
\text { as N) }\end{array}$ & $\begin{array}{c}\text { Ammonia } \\
\text { + organle, } \\
\text { dile-- } \\
\text { solved } \\
\text { (mg/l } \\
\text { as N) }\end{array}$ & \\
\hline P3 & $05-03-85$ & -. & -- & -- & $\ldots$ & -- & -- & -- & -- \\
\hline P4 & $05-03-85$ & -- &.- & $<0.010$ & $<0.100$ & 0.140 & 0.46 & 0.60 & $<0.010$ \\
\hline P6 & $05-03-85$ & -- & - & -- & -- & -- & -. & -- & -- \\
\hline P7 & $05-03-85$ & - & -- & - & -- & $\cdots$ & -- & -- & -- \\
\hline D2 & $04-30-85$ & - & $\ldots$ & -- & -. & -- & -- & -- & -- \\
\hline S3 & $04-30-85$ & -- & -- & $<0.010$ & $<0.100$ & 0.280 & 0.12 & 0.40 & $<0.010$ \\
\hline D4 & $04-29-85$ & -. & $\ldots<$ & $<0.010$ & 0.260 & 0.130 & 0.27 & 0.40 & $<0.010$ \\
\hline S5 & $04-29-85$ & - & -. & $<0.010$ & $<0.100$ & 0.630 & 0.17 & 0.80 & $<0.010$ \\
\hline D6 & $05-01-85$ & -- & $--<$ & $<0.010$ & $<0.100$ & 0.020 & 0.38 & 0.40 & $<0.010$ \\
\hline S7 & $05-01-85$ & -- & -- & -- & -- & -- & -- & -- & -. \\
\hline
\end{tabular}


Table 19. Water-quality records for ground-water and surface-water samples, Killbuck Creek valley near Wooster, Ohio-Continued

Sample 7: April 30 - May 3, 1985-Continued

\begin{tabular}{|c|c|c|c|c|c|c|c|c|c|}
\hline \multirow[b]{2}{*}{$\begin{array}{l}\text { Locai } \\
\text { Identifier }\end{array}$} & \multirow[b]{2}{*}{ Date } & \multirow[b]{2}{*}{$\begin{array}{l}\text { Soilds, } \\
\text { sum of } \\
\text { constl- } \\
\text { tuents, } \\
\text { dis- } \\
\text { solved } \\
\text { (mg/l) }\end{array}$} & \multicolumn{6}{|c|}{ Forms of nitrogen } & \multirow[b]{2}{*}{$\begin{array}{c}\text { Phos- } \\
\text { phorus, } \\
\text { ortho, } \\
\text { dis- } \\
\text { solved } \\
\text { (mg/L } \\
\text { as P) }\end{array}$} \\
\hline & & & $\begin{array}{c}\text { Nitrate, } \\
\text { dis- } \\
\text { soived } \\
\text { (mg/h } \\
\text { as N) }\end{array}$ & $\begin{array}{l}\text { Nitrile, } \\
\text { dls- } \\
\text { solved } \\
\text { (mg/L } \\
\text { as N) }\end{array}$ & $\begin{array}{l}\mathrm{NO}_{2}+ \\
\mathrm{NO}_{3}, \\
\text { dls- } \\
\text { soived } \\
\text { (mg/L } \\
\text { as } \mathrm{N} \text { ) }\end{array}$ & $\begin{array}{c}\text { Ammonia, } \\
\text { dis- } \\
\text { solved } \\
\text { (mg/L } \\
\text { as } N \text { ) }\end{array}$ & $\begin{array}{c}\text { Organic, } \\
\text { dis- } \\
\text { solved } \\
\text { (mg/L } \\
\text { as N) }\end{array}$ & $\begin{array}{c}\text { Ammonla } \\
\text { + organic, } \\
\text { dis- } \\
\text { solved } \\
\text { (mg/L } \\
\text { as N) }\end{array}$ & \\
\hline S8 & $04-30-85$ & 464 & .. & $<0.010$ & 6.70 & $<0.010$ & - & 0.40 & $<0.010$ \\
\hline D9 & $04-30-85$ & -- & -- & -- & -- & -- & -- & *.. & -. \\
\hline D10 & $05-02-85$ & - & -- & -- & -- & -- & -- & -- & -- \\
\hline $\mathbf{S 1 1}$ & $05-02-85$ & -- & -- & -- & -- & -- & -- & -- & -- \\
\hline D12 & $05-02-85$ & -- & - & - & - & -- & -- & -- & -- \\
\hline 14 & $05-03-85$ & - & -.. & $<0.010$ & $<0.100$ & 0.340 & 0.06 & 0.40 & $<0.010$ \\
\hline 17 & $05-02-85$ & -- & -- & -- & -- & -- & -- & - & .. \\
\hline 20 & $05-03-85$ & -. & -- & -- & -- & -- & -- & - & -- \\
\hline 32 & $05-01-85$ & -- & -. & $<0.010$ & 4.90 & 0.020 & 0.28 & 0.30 & $<0.010$ \\
\hline CC AT USR & $05-01-85$ & - & -- & - & -- & $\cdots$ & - & -- & -- \\
\hline KBC AT SR & $05-01-85$ & -- & 0.930 & 0.010 & 0.940 & 0.010 & 0.59 & 0.60 & $<0.010$ \\
\hline KBC AT OMR & $05-01-85$ & -- & -- & -- & -- & -- & -- & -- & -- \\
\hline
\end{tabular}

\begin{tabular}{|c|c|c|c|c|c|c|c|c|c|}
\hline $\begin{array}{l}\text { Local } \\
\text { Identifier }\end{array}$ & Date & $\begin{array}{l}\text { Alum- } \\
\text { inum, } \\
\text { total } \\
\text { recov- } \\
\text { erable } \\
(\mu \mathrm{g} / \mathrm{h} \\
\text { as Ai) }\end{array}$ & $\begin{array}{l}\text { Alum- } \\
\text { Inum, } \\
\text { dls- } \\
\text { solved } \\
\text { ( } \mu \text { g/L } \\
\text { as Al) }\end{array}$ & $\begin{array}{l}\text { iron, } \\
\text { lotal } \\
\text { recov- } \\
\text { erable } \\
\text { ( } \mu \text { gh } \\
\text { as Fe) }\end{array}$ & $\begin{array}{l}\text { Iron, } \\
\text { dis- } \\
\text { solved } \\
(\mu g h \\
\text { as Fe) }\end{array}$ & $\begin{array}{c}\text { Manga- } \\
\text { nese, } \\
\text { total } \\
\text { recov- } \\
\text { erabie } \\
\text { ( } \mu \text { g/L } \\
\text { as Mn) }\end{array}$ & $\begin{array}{c}\text { Manga- } \\
\text { nese, } \\
\text { dis- } \\
\text { solved } \\
\text { ( } \mu \mathrm{g} / \mathrm{L} \\
\text { as Mn) }\end{array}$ & $\begin{array}{l}\delta \mathrm{D}, \\
\text { per } \\
\text { mil }\end{array}$ & $\begin{array}{c}\delta^{18} \mathrm{O} \\
\text { per } \\
\mathrm{mll}\end{array}$ \\
\hline P3 & $05-(1) 3-85$ & -. & -- & -- & -- & -- & -- & -- & -- \\
\hline $\mathrm{P} 4$ & $05-03-85$ & -- & -- & -- & -- & -- & -- & -56.5 & -8.70 \\
\hline P6 & $05-03-85$ & -- & -- & -- & -- & -- & -- & -56.5 & -8.60 \\
\hline P7 & $05-03-85$ & -- & -- & -- & -- & -. & $\cdots$ &.- & -- \\
\hline D2 & $04-30-85$ & -- & -- & -- & -- & -. & - & -53.0 & -8.40 \\
\hline S3 & $04-30-85$ & 180 & 10 & 600 & 50 & 3200 & 3000 & -56.5 & -8.65 \\
\hline D4 & $04-29-8.5$ & -- & -- & -. & -- & -- & -- & -54.5 & -8.50 \\
\hline S5 & $04-29-85$ & -. & -- & -- & -- & -- & - & -55.0 & -8.40 \\
\hline D6 & $05-() 1-85$ & -- & -- & -- & -- & -- & -- & -54.0 & -8.50 \\
\hline S7 & $05-01-85$ & + & -- & -- & -- & -- & - & -- & -- \\
\hline S8 & $04-30-85$ & 180 & 20 & 720 & 5 & 520 & 510 & -54.0 & -8.45 \\
\hline D9 & $04-30-85$ & -- & -. & -- & -- & -. & -- & -54.0 & -8.50 \\
\hline D10 & $05-02-85$ & -. & -- & -- & -- & -- & -- & -60.5 & -9.30 \\
\hline S11 & $05-02-85$ & -. & -. & - & -. & -- & $\cdots$ & -- & -- \\
\hline D12 & $05-02-85$ & -. & $\cdots$ & -- & -. & -- & - & -- & -- \\
\hline
\end{tabular}


Table 19. Water-quality records for ground-water and surface-water samples, Killbuck Creek valley near Wooster, Ohio-Continued

Sample 7: April 30 - May 3, 1985-Continued

\begin{tabular}{|c|c|c|c|c|c|c|c|c|c|}
\hline $\begin{array}{l}\text { Local } \\
\text { identifler }\end{array}$ & Date & $\begin{array}{l}\text { Alum- } \\
\text { Inum, } \\
\text { total } \\
\text { recov- } \\
\text { erable } \\
\text { (flg/L } \\
\text { as Al) }\end{array}$ & $\begin{array}{l}\text { Alum- } \\
\text { Inum, } \\
\text { dls- } \\
\text { solved } \\
\text { (fig/l } \\
\text { as Ai) }\end{array}$ & $\begin{array}{l}\text { Iron, } \\
\text { total } \\
\text { recov- } \\
\text { erable } \\
\text { ( } \mu \mathrm{g} / \mathrm{L} \\
\text { as Fe) }\end{array}$ & $\begin{array}{l}\text { Iron, } \\
\text { dls- } \\
\text { soived } \\
\text { ( } \mu \text { g/l } \\
\text { as Fe) }\end{array}$ & $\begin{array}{c}\text { Manga- } \\
\text { nese, } \\
\text { lotal } \\
\text { recov- } \\
\text { erable } \\
\text { ( } \mu g / L \\
\text { as } \mathrm{Mn} \text { ) }\end{array}$ & $\begin{array}{l}\text { Manga- } \\
\text { nese, } \\
\text { dls- } \\
\text { solved } \\
\text { ( } \mu g / 2 \\
\text { as } \mathrm{Mn} \text { ) }\end{array}$ & $\begin{array}{l}\delta \mathrm{D}, \\
\text { per } \\
\text { mll }\end{array}$ & $\begin{array}{c}\delta^{18} \mathrm{O} \\
\text { per } \\
\mathrm{mil}\end{array}$ \\
\hline 14 & $05-03-85$ & -. & - & $\ldots$ & $\ldots$ & - & -- & -55.5 & -8.60 \\
\hline 17 & $05-02-85$ & -- & -- & -- & - & -- & -- & -54.0 & -8.30 \\
\hline 20 & $05-03-85$ & - & -- & -- & -- & -- & -- & -- & -- \\
\hline 32 & $05-01-85$ & -- & -- & -- & -- & -- & -- & -57.0 & -8.55 \\
\hline CC AT USR & $05-01-85$ & - & -- & -- & -- & -- & -- & -54.0 & -8.20 \\
\hline KBC AT SR & $05-01-85$ & -- & -- & -- & -- & -- & -- & -51.5 & $-7.9 n$ \\
\hline KBC AT OMR & $05-01-85$ & - & -- & .. & -- & -- & -- & -53.0 & -8.00 \\
\hline
\end{tabular}

Sample 8: June 5-7, 1985

\begin{tabular}{|c|c|c|c|c|c|c|c|c|c|}
\hline $\begin{array}{l}\text { Local } \\
\text { Identifler }\end{array}$ & $\begin{array}{l}\text { Statlon } \\
\text { number }\end{array}$ & Date & $\begin{array}{l}\text { Type } \\
\text { of } \\
\text { site } \\
\end{array}$ & Time & $\begin{array}{l}\text { Water } \\
\text { level } \\
\text { (feet) }\end{array}$ & $\begin{array}{l}\text { Spe- } \\
\text { cific } \\
\text { con- } \\
\text { duct- } \\
\text { ance } \\
\text { ( } \mu \text { S/cm) }\end{array}$ & $\begin{array}{l}\text { pH } \\
\text { (stand- } \\
\text { ard } \\
\text { unlts) }\end{array}$ & $\begin{array}{c}\text { Eh } \\
\text { (mv) }\end{array}$ & $\begin{array}{c}\text { Temper- } \\
\text { ature, } \\
\text { alr } \\
\text { (deg. C) }\end{array}$ \\
\hline P3 & 404802081583400 & $06-07-85$ & DGW & 1030 & - & 600 & 7.4 & 170 & 21.0 \\
\hline P4 & 404801081583300 & $06-07-85$ & DGW & 1000 & - & 675 & 7.1 & 180 & 23.0 \\
\hline P6 & 404759081583000 & $06-07-85$ & DGW & 0945 & -- & 960 & 7.0 & 170 & 20.0 \\
\hline P7 & 404758081582900 & $06.07-85$ & DGW & 0930 & -- & 1070 & 7.1 & 170 & 21.0 \\
\hline $\mathrm{D} 2$ & 404802081583102 & $06-06-85$ & DGW & 1030 & 29.77 & 545 & 7.5 & 120 & 23.0 \\
\hline s3 & 404802081583103 & $06-06-85$ & DGW & 0935 & 29.86 & 1900 & 6.6 & 320 & 20.0 \\
\hline D4 & 404800081584500 & $06-05-85$ & DGW & 1600 & 19.86 & 850 & 7.5 & 170 & 22.1 \\
\hline S5 & 404800081584501 & $06-06-85$ & DGW & 0830 & 19.68 & 840 & 7.0 & 190 & 19.0 \\
\hline D6 & 404839081590900 & $06-06-85$ & DGW & 1455 & 3.99 & 480 & 7.7 & 70 & 23.0 \\
\hline S7 & 404807081582000 & $06-06-85$ & DGW & 1405 & 17.82 & 720 & 6.7 & 360 & 23.0 \\
\hline S8 & 404805081582600 & $06-06-85$ & DGW & 1320 & 22.05 & 710 & 7.1 & 300 & 22.0 \\
\hline D9 & 404805081582601 & $06-06-85$ & DGW & 1240 & 27.20 & 570 & 7.6 & 120 & 21.5 \\
\hline D10 & 404752081583400 & $06-07-85$ & DGW & 1130 & 27.47 & 715 & 7.0 & 160 & 25.0 \\
\hline$S 11$ & 404752081583401 & $06-07-85$ & DGW & 1155 & 25.28 & 840 & 6.8 & 150 & 27.0 \\
\hline D12 & 404744081582100 & $06-07-85$ & DGW & 1255 & 23.42 & 790 & 6.9 & 170 & 27.0 \\
\hline 14 & 404758081585900 & $06-07-85$ & RGW & 1345 & -- & 1190 & 7.5 & 120 & 27.0 \\
\hline 32 & 404854081591200 & $06-06-85$ & DSP & 1540 & -- & 475 & 7.0 & 320 & 23.0 \\
\hline KBC AT SR & 404838081585200 & $06-07-85$ & SW & 0745 & -- & 580 & 7.7 & 330 & 17.0 \\
\hline KBC AT OMR & 03138800 & $06-07-85$ & SW & 0900 & -- & 560 & 7.9 & 360 & 19.0 \\
\hline
\end{tabular}


Table 19. Water-quality records for ground-water and surface-water samples, Killbuck Creek valley near Wooster, Ohio-Continued

Sample 8: June 5-7, 1985-Continued

\begin{tabular}{|c|c|c|c|c|c|c|c|c|}
\hline $\begin{array}{l}\text { Local } \\
\text { Identlfier }\end{array}$ & Date & $\begin{array}{c}\text { Temper- } \\
\text { ature, } \\
\text { water } \\
\text { (deg. C) } \\
\end{array}$ & $\begin{array}{c}\text { Oxygen, } \\
\text { dis- } \\
\text { solved } \\
\text { (mg'L) } \\
\end{array}$ & $\begin{array}{c}\text { Oxygen, } \\
\text { dls- } \\
\text { solved } \\
\text { (per- } \\
\text { cent } \\
\text { satur- } \\
\text { ation) } \\
\end{array}$ & $\begin{array}{c}\text { Blcar- } \\
\text { bonate, } \\
\text { WH FET, } \\
\text { fleid } \\
\left(\mathrm{mg}^{\prime} \mathrm{L} \text { as }\right. \\
\left.\mathrm{HCO}_{3}\right) \\
\end{array}$ & $\begin{array}{c}\text { Alka- } \\
\text { IInlty, } \\
\text { WH FET, } \\
\text { fleld } \\
\text { (mg/L as } \\
\mathrm{CaCO}_{3} \text { ) } \\
\end{array}$ & $\begin{array}{l}\delta \mathrm{D}, \\
\text { per } \\
\text { mil }\end{array}$ & $\begin{array}{c}\delta^{18} \mathrm{O}, \\
\text { per } \\
\mathrm{mll}\end{array}$ \\
\hline P3 & (96-07-85 & 11.0 & $<0.1$ & -- & 250 & 205 & -- & - \\
\hline P4 & $06-07-85$ & 11.0 & $<0.1$ & -- & 290 & 239 & -58.0 & -8.75 \\
\hline P6 & 06.07 .85 & 10.5 & $<0.1$ & -- & 380 & 314 & -- & -- \\
\hline P7 & ()6-(07-85 & 11.0 & 0.4 & 4 & 350 & 283 & -- & -- \\
\hline $\mathrm{D} 2$ & $06-06-85$ & 11.5 & $<0.1$ & -- & 220 & 177 & -52.5 & -8.35 \\
\hline S3 & $06-06-85$ & 11.0 & 0.1 & 1 & 580 & 474 & -- & -- \\
\hline D4 & $06-05-85$ & 11.0 & 0.1 & 1 & 330 & 273 & -53.5 & -8.35 \\
\hline S5 & $06-06-85$ & 11.0 & $<0.1$ & -- & 360 & 294 & -55.5 & -8.40 \\
\hline D6 & $06-(06-85$ & 11.5 & $<0.1$ & -- & 220 & 184 & -54.0 & -8.20 \\
\hline S7 & $06-06-85$ & 11.5 & 1.4 & 13 & 240 & 195 & -- & - \\
\hline S8 & $06-06-85$ & 12.0 & 0.2 & 2 & 320 & 266 & -54.5 & -8.55 \\
\hline D9 & $06-06-85$ & 11.5 & 0.1 & 1 & 210 & 171 & -- & -- \\
\hline D10 & $06-07-85$ & 11.5 & $<0.1$ & -- & 380 & 314 & -- & -- \\
\hline S11 & $06-07-85$ & 12.0 & $<0.1$ & -- & 440 & 358 & -- & -- \\
\hline D12 & $06-07-85$ & 11.0 & $<0.1$ & -- & 410 & 334 & -- & -- \\
\hline 14 & $06-07-85$ & 12.0 & $<0.1$ & -- & 260 & 212 & -53.0 & -7.60 \\
\hline 32 & $06-06-85$ & 12.5 & 6.1 & 59 & 160 & 130 & -52.0 & -8.15 \\
\hline KBC AT SR & $06-07-85$ & 16.0 & 7.5 & 78 & 200 & 160 & -- & -- \\
\hline KBC AT OMR & $06-07-85$ & 16.5 & 8.2 & 87 & 190 & 157 & -47.0 & -7.25 \\
\hline
\end{tabular}

Sample 9: July 2-18, 1985

\begin{tabular}{|c|c|c|c|c|c|c|c|c|c|}
\hline $\begin{array}{l}\text { Local } \\
\text { Identifier }\end{array}$ & $\begin{array}{c}\text { Station } \\
\text { number }\end{array}$ & Date & $\begin{array}{l}\text { Type } \\
\text { of } \\
\text { site }\end{array}$ & Tlme & $\begin{array}{l}\text { Water } \\
\text { level } \\
\text { (feet) }\end{array}$ & $\begin{array}{c}\text { Spe- } \\
\text { cific } \\
\text { con- } \\
\text { duct- } \\
\text { ance } \\
(\mu S / \mathrm{cm})\end{array}$ & $\begin{array}{c}\text { pH } \\
\text { (stand- } \\
\text { ard } \\
\text { units) }\end{array}$ & $\begin{array}{c}\text { Eh } \\
\text { (mv) }\end{array}$ & $\begin{array}{l}\text { Temper- } \\
\text { ature, } \\
\text { alr } \\
\text { (deg. C) }\end{array}$ \\
\hline K2 & 404839081585201 & $07-16-85$ & SGW & 1300 & -0.18 & 610 & 7.3 & 140 & 27.0 \\
\hline K3 & $4(4) 825081584901$ & $07-17-85$ & SGW & 1315 & 1.05 & 650 & 7.3 & 180 & 26.0 \\
\hline K4 & 404825081584902 & $07-17-85$ & SGW & 1250 & 1.21 & 617 & 7.3 & 240 & 26.0 \\
\hline K5 & 404818081584401 & $07-14-85$ & SGW & 1140 & 2.58 & 613 & 7.1 & 280 & 26.0 \\
\hline K6 & 404818081584402 & $07-17-85$ & SGW & 1210 & 2.54 & 618 & 7.1 & 240 & 26.0 \\
\hline $\mathrm{K} 7$ & 404813081584100 & $07-17-85$ & SGW & 1038 & 4.55 & 620 & 7.1 & 280 & 25.0 \\
\hline K9 & 404839081585202 & $07-16-85$ & SGW & 1220 & -0.13 & 628 & 7.4 & 130 & 25.0 \\
\hline P4 & 404801081583300 & $07-17-85$ & DGW & 0900 & -- & 650 & 7.1 & 230 & 21.0 \\
\hline P5 & 404800081583100 & $07-17-85$ & DGW & 0930 & -- & 833 & 6.9 & 240 & 21.0 \\
\hline D4 & 404800081584500 & $07-16-85$ & DGW & 1600 & 21.37 & 784 & 7.5 & 90 & 24.5 \\
\hline
\end{tabular}


Table 19. Water-quality records for ground-water and surface-water samples, Killbuck Creek valley near Wooster, Ohio-Continued

Sample 9: July 2-18, 1985-Continued

\begin{tabular}{|c|c|c|c|c|c|c|c|c|c|}
\hline $\begin{array}{l}\text { Local } \\
\text { Identifier }\end{array}$ & $\begin{array}{l}\text { Station } \\
\text { number }\end{array}$ & Date & $\begin{array}{c}\text { Type } \\
\text { of } \\
\text { slte }\end{array}$ & Time & $\begin{array}{l}\text { Water } \\
\text { level } \\
\text { (foet) }\end{array}$ & 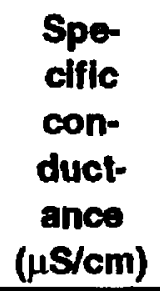 & $\begin{array}{l}\text { pH } \\
\text { (stand- } \\
\text { ard } \\
\text { unlta) }\end{array}$ & $\begin{array}{c}\text { Eh } \\
\text { (mv) }\end{array}$ & $\begin{array}{c}\text { Temper- } \\
\text { ature, } \\
\text { alr } \\
\text { (deg. C) }\end{array}$ \\
\hline S5 & 404800081584501 & $07-16-85$ & DGW & 1515 & 21.15 & 830 & 7.0 & 210 & 25.5 \\
\hline D6 & 404839081590900 & $07-16-85$ & DGW & 1040 & 4.73 & 498 & 7.8 & 220 & 21.0 \\
\hline \$8 & 404805081582600 & $07-16-85$ & DGW & 1700 & 23.05 & 593 & 7.4 & 260 & 25.0 \\
\hline 14 & 404758081585900 & $07-18-85$ & RGW & 1515 & -- & 1180 & 7.5 & 250 & 25.0 \\
\hline 17 & 404759081582100 & $07-18-85$ & DGW & 1230 & -- & 1480 & 7.1 & -- & 25.0 \\
\hline 18 & 404759081590800 & $07-18-85$ & RGW & 1430 & 54.45 & 1540 & 7.3 & 140 & 27.0 \\
\hline 19 & 404837081592900 & $07-02-85$ & RGW & 1010 & 34.56 & 1470 & 7.5 & 140 & -- \\
\hline KBC AT SR & 404838081585200 & $07-16-85$ & SW & 1115 & -- & 633 & 7.4 & 320 & 24.0 \\
\hline KBC AT OMR & 03138800 & $07-17-85$ & SW & 0745 & - & 622 & 7.9 & 280 & 19.0 \\
\hline
\end{tabular}

\begin{tabular}{|c|c|c|c|c|c|c|c|c|}
\hline $\begin{array}{l}\text { Local } \\
\text { Identifier }\end{array}$ & Date & $\begin{array}{c}\text { Temper- } \\
\text { ature, } \\
\text { water } \\
\text { (deg. C) }\end{array}$ & $\begin{array}{c}\text { Oxygen, } \\
\text { dls- } \\
\text { solved } \\
\text { (mgh) }\end{array}$ & $\begin{array}{c}\text { Oxygen, } \\
\text { dls- } \\
\text { solved } \\
\text { (per- } \\
\text { cent } \\
\text { satur- } \\
\text { ation) }\end{array}$ & $\begin{array}{c}\text { Bicar- } \\
\text { bonate, } \\
\text { WH FET, } \\
\text { fild } \\
\text { (mg/L as } \\
\text { HCO })\end{array}$ & $\begin{array}{c}\text { Alka- } \\
\text { llnity, } \\
\text { WH FET, } \\
\text { field } \\
\text { (mg/L as } \\
\text { CaCO })\end{array}$ & $\begin{array}{l}\delta \mathrm{D}, \\
\text { per } \\
\text { mII }\end{array}$ & $\begin{array}{c}\delta^{18} \mathrm{O} \\
\text { per } \\
\mathrm{mil}\end{array}$ \\
\hline $\mathrm{K} 2$ & $07-16-85$ & 17.5 & 0.2 & 2 & 280 & 229 & -52.0 & -8.05 \\
\hline K3 & $07-17-85$ & 20.5 & 0.2 & 2 & -- & -- & -51.0 & -7.50 \\
\hline K4 & $07-17-85$ & 16.5 & 0.4 & 4 & 220 & 177 & -50.0 & -7.70 \\
\hline $\mathrm{K} 5$ & $07-14-85$ & 18.0 & 0.4 & 4 & -. & -- & -52.0 & .7 .75 \\
\hline $\mathrm{K} 6$ & $07-17-85$ & 20.5 & 0.3 & 3 & -- & -- & -49.5 & -7.60 \\
\hline $\mathrm{K} 7$ & $07-17-85$ & 19.0 & 0.9 & 10 & - & - & -- & -- \\
\hline $\mathrm{K} 9$ & $07-16-85$ & 14.0 & 0.2 & 2 & 260 & 210 & -- & -- \\
\hline P4 & $07-17-85$ & 10.5 & 0.4 & 4 & 280 & 227 & -55.5 & -8.65 \\
\hline P5 & $07-17-85$ & 10.0 & 0.5 & 5 & 360 & 297 & -58.0 & -8.80 \\
\hline D4 & $07-16-85$ & 12.5 & 0.2 & 2 & 340 & 278 & -52.5 & -7.95 \\
\hline S5 & $07-16-85$ & 12.0 & 0.3 & 3 & 360 & 292 & -- & -- \\
\hline D6 & $07-16-85$ & 11.5 & $<0.1$ & -- & 220 & 183 & -52.0 & -7.40 \\
\hline S8 & $07-16-85$ & 12.0 & 0.2 & 2 & 290 & 239 & -52.5 & -7.90 \\
\hline 14 & $07-18-85$ & 12.0 & $<0.1$ & -- & -- & -- & -55.0 & .8 .60 \\
\hline 17 & $07-18-85$ & 12.0 & 0.5 & 5 & -- & -- & -53.5 & -8.35 \\
\hline 18 & $07-18-85$ & 12.0 & 0.3 & 3 & -- & -- & -55.0 & -8.65 \\
\hline 19 & $07-02-85$ & 13.0 & 0.1 & -- & -- & - & -- & -- \\
\hline KBC AT SR & $07-16-85$ & 21.5 & 7.4 & 87 & 220 & 181 & $\ldots$ & -- \\
\hline KBC AT OMR & $07-17-85$ & 19.5 & 7.9 & 89 & 220 & 178 & -45.5 & -6.75 \\
\hline
\end{tabular}


Table 19. Water-quality records for ground-water and surface-water samples, Killbuck Creek valley near Wooster, Ohio-Continued

Sample 10: August 26-28, 1985

\begin{tabular}{|c|c|c|c|c|c|c|c|c|c|}
\hline $\begin{array}{l}\text { Local } \\
\text { Identifier }\end{array}$ & $\begin{array}{l}\text { Station } \\
\text { number }\end{array}$ & Date & $\begin{array}{c}\text { Type } \\
\text { of } \\
\text { elte }\end{array}$ & Time & $\begin{array}{l}\text { Water } \\
\text { level } \\
\text { (feet) }\end{array}$ & $\begin{array}{l}\text { Spe- } \\
\text { clfle } \\
\text { con- } \\
\text { duct- } \\
\text { ance } \\
(\mu \mathrm{S} / \mathrm{cm})\end{array}$ & $\begin{array}{l}\text { pH } \\
\text { (stand- } \\
\text { ard } \\
\text { units) }\end{array}$ & $\begin{array}{c}\text { Eh } \\
\text { (mv) }\end{array}$ & $\begin{array}{l}\text { Temper- } \\
\text { afure, } \\
\text { alr } \\
\text { (deg. C) }\end{array}$ \\
\hline K3 & 404825081584901 & $08-27-85$ & SGW & 1130 & -- & 584 & 7.2 & -- & -- \\
\hline $\mathrm{K} 4$ & 404825081584902 & $08-27-85$ & SGW & 1155 & -- & 618 & 7.1 & -- & -- \\
\hline K5 & 404818081584401 & $08-27-85$ & SGW & 1305 & -- & 601 & 7.0 & -- & $\ldots$ \\
\hline K6 & 404818081584402 & $08-27-85$ & SGW & 1340 & -- & 585 & 7.0 & 260 & -- \\
\hline K7 & 404813081584100 & $08-26-85$ & SGW & 1435 & -- & 583 & 6.9 & 310 & 23.0 \\
\hline P3 & 404802081583400 & $08-26-85$ & DGW & 1210 & 41.33 & 747 & 7.3 & 170 & 21.5 \\
\hline P4 & 404801081583300 & $08-26-85$ & DGW & 1255 & -- & 787 & 7.1 & 190 & 21.5 \\
\hline P5 & 404800081583100 & $08-26-85$ & DGW & 1300 & - & 1040 & 7.0 & 240 & 21.5 \\
\hline P6 & 404759081583000 & $08-26-85$ & DGW & 1335 & 36.83 & 1130 & 6.9 & 170 & 22.1) \\
\hline P7 & 404758081582900 & $08-26-85$ & DGW & 1400 & 38.50 & 1260 & 7.1 & 160 & 24.0 \\
\hline D4 & 404800081584500 & $08-28-85$ & DGW & 1000 & 23.05 & 868 & 7.5 & 130 & 20.0 \\
\hline S5 & 404800081584501 & $08-28-85$ & DGW & 1030 & 22.87 & 832 & 7.0 & 200 & 21.0 \\
\hline D6 & 404839081590900 & $08-28-85$ & DGW & 1240 & 5.13 & 490 & 7.7 & 100 & 23.0 \\
\hline S8 & 404805081582600 & $08-28-85$ & DGW & 1145 & 25.13 & 607 & 7.2 & 270 & 24.0 \\
\hline 14 & 404758081585900 & $08-26-85$ & RGW & 1610 & -- & 1360 & 7.5 & 250 & 25.0 \\
\hline 17 & 404759081582100 & $08-26-85$ & DGW & 1510 & - & 1670 & 7.1 & 250 & 23.0 \\
\hline 18 & 404759081590800 & $08-28-85$ & RGW & 1400 & 55.03 & 1540 & 7.2 & 110 & 24.0 \\
\hline KBC AT SR & 404838081585200 & $08-27-85$ & SW & 0945 & -- & 623 & 7.9 & -- & 21.0 \\
\hline KBC AT OMR & 03138800 & $08-27-85$ & SW & 0945 & -- & 623 & 7.9 & -- & 20.0 \\
\hline $\begin{array}{l}\text { Local } \\
\text { identiller }\end{array}$ & Date & $\begin{array}{c}\text { Temper- } \\
\text { ature, } \\
\text { water } \\
\text { (deg. C) } \\
\end{array}$ & $\begin{array}{c}\text { Oxygen, } \\
\text { dls- } \\
\text { solved } \\
\text { (mglh) }\end{array}$ & $\begin{array}{c}\text { Oxygen, } \\
\text { dls- } \\
\text { solved } \\
\text { (per- } \\
\text { cent } \\
\text { satur- } \\
\text { ation) } \\
\end{array}$ & $\begin{array}{c}\text { Blcar- } \\
\text { bonate, } \\
\text { WH FET, } \\
\text { feld } \\
\text { (mgll as } \\
\mathrm{HCO}_{3} \text { ) }\end{array}$ & $\begin{array}{r}A \\
\text { if } \\
\text { (m } \\
\text { Ce }\end{array}$ & $\begin{array}{l}\text { Aika- } \\
\text { inlty, } \\
\text { H FET, } \\
\text { leld } \\
\text { g/L as } \\
\left.\mathrm{aCO}_{3}\right) \\
\end{array}$ & $\begin{array}{l}\delta D, \\
\text { per } \\
\text { mll }\end{array}$ & $\begin{array}{c}\delta^{18} \mathrm{O} \\
\text { per } \\
\text { mil }\end{array}$ \\
\hline K3 & $08-27-85$ & 21.0 & 0.2 & 2 & 210 & & 170 & -41.5 & -6.65 \\
\hline K4 & $08-27-85$ & 19.5 & 0.2 & 2 & 220 & & 180 & -42.0 & .0 .60 \\
\hline K5 & $08-27-8.5$ & 18.5 & 0.2 & 2 & 220 & & 178 & -41.5 & -6.75 \\
\hline K6 & $08-27-85$ & 20.5 & 0.2 & 2 & 210 & & 172 & -42.0 & -6.75 \\
\hline K7 & $08-26-85$ & 19.5 & 0.3 & 3 & 210 & & 168 & -- & -- \\
\hline P3 & $08-26-85$ & 11.0 & $<0.1$ & -- & 260 & & 211 & -- & -- \\
\hline P4 & $08-26-85$ & 10.5 & 0.1 & 1 & 270 & & 222 & -54.0 & -8.60 \\
\hline P5 & $08-26-85$ & 10.0 & 0.2 & 2 & 370 & & 303 & -56.0 & -8.70 \\
\hline P6 & $08-26-85$ & 10.5 & 0.2 & 2 & 380 & & 315 & - & -- \\
\hline P7 & ()8-26-85 & 11.0 & 0.1 & 1 & 350 & & 286 & -- & -- \\
\hline
\end{tabular}


Table 19. Water-quality records for ground-water and surface-water samples, Killbuck Creek valley near Wooster, Ohio-Continued

Sample 10: August 26-28, 1985-Continued

\begin{tabular}{|c|c|c|c|c|c|c|c|c|}
\hline $\begin{array}{l}\text { Local } \\
\text { identiffer }\end{array}$ & Date & $\begin{array}{c}\text { Temper- } \\
\text { ature, } \\
\text { water } \\
\text { (deg. C) } \\
\end{array}$ & $\begin{array}{c}\text { Oxygen, } \\
\text { dls- } \\
\text { solved } \\
\text { (mg/L) }\end{array}$ & $\begin{array}{c}\text { Oxygen, } \\
\text { dls- } \\
\text { solved } \\
\text { (per- } \\
\text { cent } \\
\text { satur- } \\
\text { ation) } \\
\end{array}$ & $\begin{array}{c}\text { Blcar- } \\
\text { bonate, } \\
\text { WH FET, } \\
\text { ffeld } \\
\text { (mg/L as } \\
\left.\mathrm{HCO}_{3}\right)\end{array}$ & $\begin{array}{c}\text { Alka- } \\
\text { linity, } \\
\text { WH FET, } \\
\text { field } \\
\text { (mg/L as } \\
\left.\mathrm{CaCO}_{3}\right) \\
\end{array}$ & $\begin{array}{l}\delta \mathrm{D}, \\
\text { per } \\
\mathrm{mIl} \\
\end{array}$ & $\begin{array}{c}\delta^{18} \mathbf{0} \\
\text { per } \\
\text { mll }\end{array}$ \\
\hline D4 & $08-28-85$ & 13.0 & $<0.1$ & -- & 340 & 277 & -55.0 & -8.45 \\
\hline$\$ 5$ & $08-28-85$ & 12.5 & $<0.1$ & -- & 350 & 288 & -- & - \\
\hline D6 & $08-28-85$ & 12.0 & $<0.1$ & -- & 230 & 190 & -53.0 & -8.25 \\
\hline$\$ 8$ & $08-28-8.5$ & 13.0 & $<0.1$ & -- & 260 & 209 & -52.0 & -8.25 \\
\hline 14 & $08-26-85$ & 12.0 & 0.1 & 1 & 270 & 219 & -54.5 & -8.55 \\
\hline 17 & $08-26-85$ & 12.0 & 0.2 & 2 & 390 & 316 & $-55,0$ & -8.65 \\
\hline 18 & $08-28-85$ & 13.0 & 0.1 & 1 & 360 & 296 & -55.5 & -8.40 \\
\hline KBC AT SR & $08-27-85$ & 19.5 & 7.4 & 83 & 230 & 186 & -42.0 & -7.15 \\
\hline KBC AT OMR & $08-27-85$ & 19.0 & 7.4 & 82 & 230 & 186 & -45.0 & -7.15 \\
\hline
\end{tabular}

